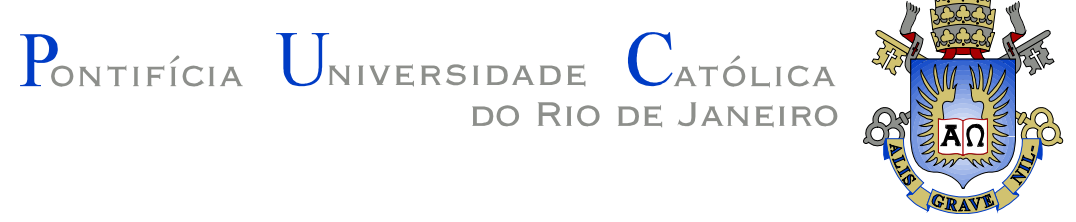

Roberto Marcelo da Silva

\title{
A descida de Cristo à mansão dos mortos Uma perspectiva teológica latino-americana
}

\section{Tese de Doutorado}

Tese apresentada ao Programa de Pós-graduação em Teologia da PUC-Rio como requisito parcial para a obtenção do grau de Doutor em Teologia.

Orientador: Prof. Paulo Fernando Carneiro de Andrade

Rio de Janeiro

Maio de 2019 


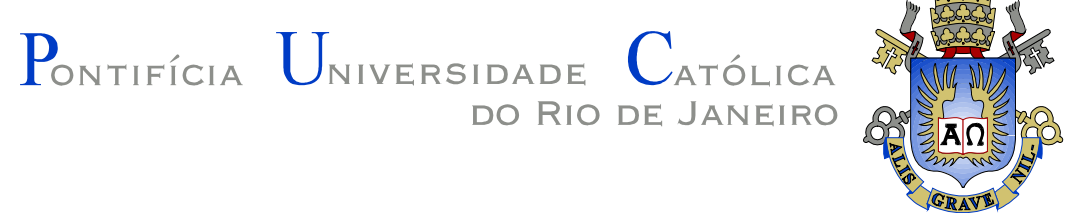

Roberto Marcelo da Silva

\begin{abstract}
A descida de Cristo à mansão dos mortos Uma perspectiva teológica latino-americana
\end{abstract}

Tese apresentada como requisito parcial para a obtenção do grau de Doutor em pelo programa de Pós-Graduação em Teologia da PUC-Rio. Aprovada pela Comissão Examinadora abaixo.

Prof. Paulo Fernando Carneiro de Andrade

Orientador

Departameto de Teologia - PUC-Rio

Prof. Luiz Fernando Ribeiro Santana Departamento de Teologia - PUC-Rio

Profa. Maria Clara Lucchetti Bingemer

Departamento de Teologia - PUC-Rio

Prof. Carlos Alberto Steil

UFRGS

Prof. Degislando Nóbrega de Lima

UNICAP

Rio de Janeiro, 28 de Maio de 2019 
Todos os direitos reservados. É proibida a reprodução total ou parcial do trabalho sem autorização da universidade, do autor e do orientador.

Roberto Marcelo da Silva

Possui graduação em Filosofia pela Universidade de Taubaté (2004), graduação em Teologia pela Faculdade Dehoniana (2008) e mestrado em Teologia pela Pontifícia Universidade Católica de São Paulo (2011).

Ficha catalográfica

Silva, Roberto Marcelo da

A descida de Cristo à mansão dos mortos. Uma perspectiva teológica latino-americana / Roberto Marcelo da Silva ; orientador: Paulo Fernando Carneiro de Andrade.- 2019.

314 f. : il. color. ; $30 \mathrm{~cm}$

Tese (doutorado)-Pontifícia Universidade Católica do Rio de Janeiro, Departamento de Teologia, 2019.

Inclui bibliografia 


\section{Agradecimentos}

Ao meu orientador Professor Fernando Carneiro de Andrade pelo estímulo e parceria para a realização deste trabalho.

Ao CNPq e à PUC-Rio, pelos auxílios concedidos, sem os quais este trabalho não poderia ter sido realizado.

Aos professores que participaram da Comissão examinadora.

A todos os amigos e familiares que de uma forma ou de outra me estimularam ou me ajudaram.

O presente trabalho foi realizado com o apoio da Coordenação de Aperfeiçoamento de Pessoal de Nível Superior - Brasil (CAPES) - Código de Financiamento 001 


\section{Resumo}

Da Silva, Roberto Marcelo; Andrade, Paulo Fernando Carneiro de. A descida de Cristo à mansão dos mortos. Uma perspectiva teológica latinoamericana. Rio de Janeiro, 2019. 314 p. Tese de doutorado - Departamento de Teologia, Pontifícia Universidade Católica do Rio de Janeiro.

O objetivo deste trabalho é evidenciar as interpretações teológicas mais expressivas sobre a Descida de Cristo à mansão dos mortos (vitória, pregação e solidariedade). Com os principais elementos contidos na reflexão teológica deste artigo de fé, tentaremos apresentar a descida de Cristo aos infernos como um modelo para a atuação e práxis libertadora da Igreja, mostrando como um antigo artigo de fé pode ser traduzido, de modo a fazer sentido para o fiel do séc. XXI. Assim sendo, se Cristo desceu aos infernos, Ele desce até a nossa realidade e aos nossos desafios sociais. Por analogia poderíamos dizer que aquilo que seria mansão dos mortos como Sheol, Hades, Inferos e Refaim, Cristo também teria descido a nossa condição humana, muitas vezes desprovida de esperança, invisível socialmente ou incapaz de agir por um sistema de opressão. A atuação da Igreja seria a mesma daquela promovida por Cristo quando pregou levando uma nova oportunidade de salvação na morada dos mortos ou quando o Cristo se fez solidário de corpo e alma para que toda a obra criada pudesse participar da graça de Deus. É a tentativa em dar uma práxis eclesial a partir das interpretações cristológicas e soteriológicas sobre o Descensus, fazendo com que a descida de Cristo à morada dos mortos se insira dentro do contexto latino-americano.

\section{Palavras-chave}

Teologia; Cristologia; Jesus Cristo; Sheol; Hades; Inferos; Refaim 


\section{Abstract}

Da Silva, Roberto Marcelo; Andrade, Paulo Fernando Carneiro de. The descent of Christ in to hell. A Latin American theological perspective. Rio de Janeiro, 2019. 314 p. Doctoral Thesis - Departamento de Teologia, Pontifícia Universidade Católica do Rio de Janeiro.

This project objective is to highlight the most expressive theological interpretations about Christ's descent to the death manor (triumph, preaching and solidarity). With the main features contained in the theological reflection in this scientific faith article, we will try to present Christ's descent in to hell as a type for the Church liberator performance and praxis, showing like an old faith article can be translated in order to make sense to the believers from the XXI century. Therefore, if Christ descended in to hell he would descend until our realities and our social challenges. By the analogy, we could say that it would be the death manor such as Sheol, Hades, Hell and Rephaim, Christ would have descended to our human condition, often without hope, socially unseen or incapable to act because of an oppression system. The church performance would be the same as the one promoted by Christ. When he preached taking a new redemption opportunity to the deceased abode or when Christ was body and soul solidary for every accomplishments that could take part of God's grace. It's an attempt to give an ecclesiastic praxis by the Christological and soteriological interpretations about the descensus, which Christ's descent to the deceased abode gets inserted into LatinAmerican context.

\section{Keywords}

Theology; Christology; Jesus Christ; Sheol; Hades; Inferos; Refaim 


\section{Abreviaturas}

$\mathrm{AH} \quad$ Adversus Hæreses

CCEC Compêndio do Catecismo da Igreja Católica

CCL Corpus Christianorum. Series Latina

CEC Catecismo da Igreja Católica

DPAC Dicionário Patrístico e de Antiguidades Cristãs

PG Patrologia Grega (Migne)

PL Patrologia Latina (Migne)

SChr Sources Chrétiennes 


\section{Sumário}

Introdução 12

Capítulo I - A realidade latino-americana 18

1.1 - Aspectos econômicos 18

1.1.1 - Alienação que afeta a sociedade 20

1.1 .2 - Alienação e passividade 26

1.1.3 - O Subdesenvolvimento na América Latina 28

1.1.4 _A força do sistema capitalista 30

1.2 - A vida política 38

1.2.1 - Insensibilidade diante dos marginalizados $\quad 40$

1.2.2 - A Injustiça como fator de violência 42

1.3 - Consequencias sociais $\quad 45$

1.3.1 - A pobreza e a educação na sociedade latino-americana 51

1.3.2 - Os desafios de uma invisibilidade social 53

1.4 - A situação religiosa $\quad 59$

1.5 - O desafio ecológico na América Latina 66

Capítulo II - A doutrina da descida de Cristo a morada dos mortos

2.1 - A descida de Cristo a morada dos mortos:

fundamentos bíblicos

76

2.1.1 - O universo semita

77

2.1.2 - Descer e suber da morada dos mortos

84

2.1.3 - O Hades

88

2.1.4 - Hades no Novo Testamento

90

2.2 - A descida de Cristo à morada dos mortos

nos primórdio do cristianismo 92

2.2.1 - Mt 12,40 93

2.2.2-Mt 27,51-54 95

2.2.3-Rm 10,6-8 97

$2.2 .4-$ Ef 4,8-9 98

2.2.5 - At 2,24-31 99

$\begin{array}{ll}2.2 .6-A p ~ 1,17-18 & 100\end{array}$

$\begin{array}{ll}2.2 .7-1 P d 3,18-19 ; 4,6 & 102\end{array}$ 
2.3 - O desenvolvimento sistemático da descida de Cristo

a morada dos mortos 112

2.3.1 - As interpretações predominantemente soteriológicas 113

2.3.2 - A pregação de Cristo aos mortos 113

2.3.3 - A descida a morada dos mortos como vitória sobre os poderes infernais

2.3.4 - A peculiar abordagem de Santo Agostinho 124

2.4 - As interpretações predominantemente cristológicas 128

2.5 - Os Símbolos de fé 134

2.5.1 - Os Símbolos filo-arianos 134

2.5.2 - O Símbolo de Sírmio 137

2.5.3 - O Símbolo de Niceia 138

2.5.4 - O Símbolo de Constantinopla 140

2.5.5 - Os Símbolos Católicos - O Símbolo de Aquileia 142

2.5.6 - O Símbolo Apostólico 143

2.5.7 - O Símbolo (Pseudo) Atanasiano 144

2.6 - O testamento litúrgico (Lex Orandi) 145

Capítulo III - Os desdobramentos da descida de Cristo à morada dos mortos nos períodos medieval e moderno 148

3.1 - A teologia medieval - Santo Tomás de Aquino 148

3.2 - A teologia moderna - Calvino 156

3.2.1 - São Roberto Bellarmino 159

3.2.2 - O Catecismo Tridentino 161

3.3 - A descida de Cristo a mansão dos mortos no período contemporâneo 162

3.4 - O magistério de João Paulo II 162

3.5 - O Catecismo da Igreja Católica 164

3.6 - Teólogos de língua alemã 165

3.6.1 - Hans Urs von Balthasar 165

3.6.2 - Joseph Ratzinger 174

3.6.3 - Karl Rahner 178

3.6.4 - Hans Küng 179

3.7 - Teólogos de língua francesa 182

3.7.1 - Jean Galot $\quad 182$ 
3.7.3 - Louis Lochet 187

3.7.4 - Adolphe Gesché 189

3.8 - Um teólogo brasileiro: Leonardo Boff 194

Capítulo IV - A descida aos infernos como modelo

para a atuação da Igreja

4.1 - O "lugar dos mortos" à luz da teologia

latino-americana

4.2 - A pregação de Cristo aos mortos - O Evangelho como fermento de mudanças socias

4.2.1 - O anúncio do Reino na promoção da

Responsabilidade Cristã

4.2.2 - Deus se insere na história - A missão profética da Igreja

4.2.3 - A Palavra de Deus a serviço da libertação

4.3 - Cristo desce a morada dos mortos como libertação

e resgate de muitos. A Igreja na promoção da libertação dos mais pobres e oprimidos

4.3.1 - O resgate e a libertação de muitos como opção preferencial pelos pobres

4.3.2 - A Boa-Nova liberta denunciando as causas da miséria e opressão

4.3.3 - O compromisso eclesial - Uma Igreja que promove a salvação e a libertação aos pobres

4.4 - Uma Igreja mais solidária aos excluídos a luz da descida de Cristo a mansão dos mortos

4.4.1 - A Igreja que ouve o clamor dos pobres e dos excluídos

4.4.2 - Uma solidariedade libertadora na Igreja

4.4.3 - O respeito à obra criada, a necessidade de uma solidariedade ecológica 


\section{Lista de figuras}

Figura 1 - Compreensão do mundo dos antigos semitas $\quad 15$

Figura 2 - Descensus representado no sentido soteriológico 19

Figura 3 - Descensus representado como pregação

Figura 4 - Descensus representado como vitória nos infernos $\quad 91$

Figura 5 - Esquema do inferno segundo a Divina Comédia 148

Figura 6 - Hades personificado 344 


\section{Introdução}

A afirmação da descida de Cristo à mansão dos mortos (ou aos infernos ${ }^{1}$ ) faz parte do depósito da fé, atestado em uma de suas mais expressivas manifestações, o assim chamado Símbolo apostólico ${ }^{2}$. Uma infinidade de fiéis, das diversas denominações cristãs, expressa com essas palavras aquilo que acredita acerca do mistério de Cristo.

Se a introdução deste artigo nos Símbolos católicos parece ter-se dado pela primeira vez em Aquiléia ${ }^{3}$ (Itália, por volta do ano 390), o tema, certamente, pertence à antiga tradição cristã, podendo ser encontrado nos mais diversos tipos de escritos eclesiásticos: apologias ${ }^{4}$, apócrifos ${ }^{5}$, homilias ${ }^{6}$, relatos legendários $^{7}$, textos litúrgicos ${ }^{8}$, além de inúmeras representações artísticas ${ }^{9}$.

Seu estudo, porém, não é fácil; escassos (se não inexistentes) são os textos bíblicos que a fundamentam diretamente, bem como diferentes são as interpretações que a doutrina recebeu ao longo dos tempos.

\footnotetext{
${ }^{1}$ Como veremos, os termos para se referir ao lugar dos mortos sofrem mudanças na Escritura e tradição católica. Por isso, no presente trabalho, usaremos indiferenciadamente tanto "descida de Cristo à morada dos mortos" como "descida de Cristo aos infernos", bem como os sinônimos latinos "descensus ad inferos" ou "ad infera" (às vezes na forma abreviada "descensus"). Salvo quando indicado (expressamente ou pelo contexto, o termo não pretende referir-se ao "inferno dos condenados".

${ }^{2}$ Contestado pelos orientais no concílio de Florença (Ferrara, ano 1438), que afirmaram nunca ter notícia dele, o Símbolo dito Apostólico acabou se impondo como profissão de fé reconhecida pela maioria das Igrejas e Comunidades eclesiais cristãs (KELLY, J.N. D.; Primitivos Credos Cristianos, 1980, pp. 19 e 435-436).

${ }^{3}$ DHü16

${ }^{4}$ IRINEU DE LYON, AH, 27,2; JUSTINO, Diálogo com Trifão, 72,4.

${ }^{5}$ EVANGELHO DE PEDRO, In: Apócrifos da Bíblia e pseudo-epígrafos, 2005, pp. 39-42.

${ }^{6}$ MELITÓN DE SARDES, Sur la Pâques, 1966, pp. 120-124 (Sources Chrétiennes, 123).

${ }^{7}$ A descida de Cristo aos infernos, parte do chamado Evangelho de Nicodemos (DESCIDA DE CRISTO AO INFERNO (Versão Grega). In: Apócrifos da Bíblia e pseudo-epígrafos, 2005, pp. 5,1$6,2)$

${ }^{8}$ Segunda Estância dos Encômios do Sábado Santo na Liturgia Bizantina. Disponível em: http://www.ecclesia.com.br/biblioteca/liturgia/o_grande_sabado_santo.html. Acessado em: 08 jan 2010; ou Oração da Primeira Incensação da Divina Liturgia: "Ó Cristo, estavas de corpo no sepulcro e com a alma nos infernos e, como Deus, no paraíso com o ladrão e no trono com o Pai e o Espírito Santo, ocupando todo lugar, Tu, o Onipresente!" Disponível em http://www.ecclesia.com.br/biblioteca/liturgia/a_divina_liturgia_de_sao_joao_crisostomo_segunda _parte.html\#II. Acessado em 12 de Janeiro de 2010.

${ }^{9}$ PASSARELLI, G., Iconos. Festividades Bizantinas, 1999, p. 11-16.
} 
Nossa pesquisa pretende, primeiramente, contextualizar a origem da doutrina do Descensus, com a realidade latino-americana, e não somente esclarecer as perspectivas teológicas deste artigo de fé, mas, também refletir qual relevância teria este para a práxis eclesial.

De princípio, a questão fundamental é esclarecer a perspectiva sob a qual poderemos promover uma práxis eclesial a partir do conteúdo de fé sobre o Descensus. A América Latina se torna o lugar teológico sob o qual nossa reflexão pode se desenvolver. Os desafios que a realidade oprimida do continente vem oferecer podem nos dar dados para refletir as possíveis respostas às inúmeras dificuldades que a sociedade latino-americana apresenta.

Como o objetivo da pesquisa é refletir uma práxis eclesial, vemos que a metodologia de pesquisa mais adequada seria o Ver, o Julgar e o Agir. Este método de pesquisa pode ajudar a despertar uma consciência crítica, levando a assumir compromissos de transformação social. É desta forma que podemos nos situar dentro da realidade concreta, confrontá-la com a fé cristã e a Palavra de Deus, e consequentemente, encaminhar para uma ação transformadora, para melhorar, corrigir ou até mesmo transformar uma realidade.

No primeiro Capítulo, dentro da compreensão do Ver, devemos reconhecer que os níveis de vida e de liberdade no contexto latino-americano, são extremamente precários. Vemos uma superabundância de meios de vida de uma minoria à custa da miséria, quase absoluta, da grande maioria populacional. A desigualdade social, pobreza, crise política, degradação do meio ambiente, são situações que o povo latino-americano percebe, e no silêncio convive com todos estes desafios, muitas vezes sem voz suficiente para clamar por justiça e por condições de vida melhor.

Ao analisar as Sagradas Escrituras sobre o Descensus, buscamos luzes e orientações na doutrina da Igreja, para que possamos refletir valores éticos a serem oferecidos como práxis eclesial. É, no segundo capítulo, na perspectiva do Julgar, pretendemos apresentar o pensamento bíblico, no qual o artigo de fé se desenvolve e 
demonstra seu impacto sobre o mesmo. Tal estudo bíblico, particularmente veterotestamentário, acerca da morte e da morada dos mortos, é necessário para a compreensão do tema que propomos. Isto não apenas pelo motivo óbvio do horizonte bíblico, no qual a doutrina se desenvolveu, mas também pelo frequente recurso que os escritores eclesiásticos fizeram a textos do Antigo Testamento para explicar o sentido da afirmação ${ }^{1}$.

Neste segundo capítulo, também apresentaremos os textos do Novo Testamento, que tradicionalmente se utilizam como fundamentação bíblica para a afirmação do Descensus, procurando analisar a consistência exegética de tal uso. Nossa atenção se voltará à teologia dos Padres, período em que a doutrina da descida de Cristo aos infernos apresentou maior desenvolvimento, fixando as principais linhas da reflexão teológica posterior. Analisaremos, particularmente, a abordagem soteriológica com que os Padres refletiram sobre nosso tema, sem deixar de lado suas implicações para a Cristologia.

No terceiro capítulo, ainda dentro da perspectiva do Julgar, nosso estudo se voltará aos teólogos medievais, com os quais se fixou o que poderíamos chamar de ortodoxia católica a respeito do tema, através de uma maior precisão dos termos, e a tentativa de esclarecer e acomodar o conjunto da doutrina, aquilo que ainda ambíguo no período anterior. Como veremos, a reflexão teológica desse período produziu certa estagnação no estudo da descida de Cristo aos infernos, que perdurou por todo o período moderno.

A reflexão sobre a descida aos infernos floresceu, com novo vigor, na teologia contemporânea. Com releituras originais e, até mesmo, com abordagens inéditas, os autores revitalizaram o estudo do tema, que adquiriu uma complexidade ainda maior. Nossa apresentação será dividida, grosso modo, por grupos linguísticos.

\footnotetext{
${ }^{1}$ Para fundamentar a afirmação em seu comentário ao Símbolo de Aquiléia (primeiro símbolo católico em que ela aparece), Rufino de Aquiléia utiliza fundamentalmente textos do Antigo Testamento (S1 22,16; 30,10; 69,3; 16,10; 30,4; 71,20; 88,5) GOUNELLE, R. La descente du Christ aux enfers. In: Cahiers Évangile, 2004, p. 47.
} 
Pretendemos, depois disso, analisar a presença da afirmação da descida de Cristo aos infernos na teologia e na vida da Igreja, e as consequências de tal afirmação para a cristologia e, principalmente, para a soteriologia (âmbito em que a doutrina mais se desenvolveu). A apresentação seguirá uma ordem predominantemente cronológica. No que se refere aos teólogos, procuraremos identificar a contribuição específica de autores à compreensão do tema, bem como as dificuldades que algumas interpretações apresentam.

Acreditamos que tal apresentação será suficiente para mostrar a relevância do tema e até onde se pode chegar no panorama do pensamento teológico. A pesquisa exegético-sistemática acerca do mesmo pode abrir caminhos para uma reflexão posterior. É isso que tentaremos mostrar, ao afirmar que a descida de Cristo junto aos mortos, para o homem atual, pode ter um significado e apresentar o modo como o antigo artigo de fé pode ser traduzido de maneira a fazer sentido para o fiel do séc. XXI.

No quarto capítulo, no ponto de vista do Agir, podemos fazer essa aproximação do artigo de fé com a realidade latino-americana como reflexão para o agir pastoral. É na práxis eclesial que o cristão pode atuar na comunidade cristã ou na sociedade, percebendo em Cristo uma forma de agir. $\mathrm{O}$ artigo de fé, da descida de Cristo aos infernos, nos faz questionar qual teria sido a atuação de Cristo ao descer ao lugar dos mortos.

Para a práxis eclesial, nossa pesquisa pretende fazer uma analogia da doutrina da descida aos infernos dentro da realidade latino-americana. A contextualização se daria na análise terminológica dos termos Sheol, Hades, Inferos e Refaim, buscando uma hermenêutica que possa aproximar esses "lugares de pós-morte" com o contexto latino-americano. Se Sheol quer expressar aqueles que se encontravam sem esperança na região dos mortos, quem seriam aqueles que se encontram sem esperança em nossa sociedade? Da mesma forma, se Hades quer dizer invisível, segundo Platão, quem seriam aqueles considerados invisíveis sociais? Se Inferos expressa uma condição de inferioridade, pelo fato dos mortos se encontrarem abaixo da terra, seria conveniente apresentar quem estaria numa condição de inferioridade social. O mesmo 
acontece com a expressão Refaim (sombras), que no Antigo Testamento considerava que após a morte, as sombras daqueles que morreram estariam incapacitados de agir na mansão dos mortos, presos por um sistema. Quem seriam aqueles oprimidos, sem voz e sem vez presentes nem nossa sociedade latino-americana? Esta contextualização nada mais seria do que uma tentativa em aproximar o artigo de fé, sobre o descensus, dentro dos grandes desafios presentes em nossa sociedade.

O referencial teórico para a fundamentação destes grandes desafios sociais em nossa sociedade teria como base os documentos do CELAM, assim como grandes teólogos que contribuíram por uma reflexão social. Tais perspectivas poderão contribuir para uma práxis eclesial de acordo com as mais expressivas interpretações teológicas, desenvolvidas sobre o descensus pelos Padres da Igreja.

Ao apresentar as interpretações teológicas mais expressivas sobre o descensus (pregação, vitória e solidariedade), seria conveniente oferecer uma aplicação prática em vista destas mesmas. Os principais elementos contidos na reflexão teológica, tentará apresentar a descida de Cristo aos infernos como modelo para a atuação e práxis libertadora da Igreja, mostrando que um antigo artigo de fé pode ser compreendido de um modo diferente.

A ação de Cristo em descer à morada dos mortos revela a mesma iniciativa de Deus em se inserir na realidade latino-americana. Se Cristo pregou, dando uma nova oportunidade àqueles que morreram, o cristão também pode pregar e anunciar a BoaNova de Cristo a todos os povos. Se Cristo foi solidário, mesmo após a morte com aqueles que morreram, a nossa solidariedade, a exemplo de Cristo, seria a nossa identificação com este Deus que se solidarizou com a humanidade tanto em corpo quanto em alma.

É a descida de Cristo à mansão dos mortos que vem contribuir por uma práxis para a vida cristã em correspondência com a atuação de Jesus, porém, não no alémmorte, mas sim, na realidade concreta de nossa sociedade latino-americana. 
Por fim, vemos que através de uma rica experiência histórica, cheia de luzes e de sombras na realidade latino-americana, a grande missão da Igreja tem sido seu compromisso na fé com o homem da América Latina. Não obstante, não podemos perder a riqueza cultural presente em nossa Igreja, e ver que artigos de fé podem ser lidos e relidos de acordo com nosso contexto, permitindo novas formas de agir para o cristão atual. É nossa cultura de fé que pode enriquecer nosso campo de ação e ampliar cada vez mais a ação salvífica de Deus a partir da ação humana. 


\section{Capítulo I - A realidade latino-americana}

\section{1 - Aspectos econômicos}

A realidade da América Latina nos apresenta uma série de situações que nos fazem refletir as condições da pessoa com seus valores, direitos e deveres. A pobreza, injustiça social, violência, corrupção, desigualdade social sempre estiveram na vida do povo latino-americano. Em vista das inúmeras dificuldades relacionadas à pobreza, em apoio aos mais necessitados, é necessário conhecer e apresentar a realidade social na América Latina.

Uma das maiores características que marca o povo latino-americano é a interferência dos países desenvolvidos, que estabeleciam um imperialismo ideológico, de forma a não hesitar em promover intervenções militares diretas ${ }^{2}$. O receio pela expansão do comunismo fez com que os Estados Unidos se julgassem no direito de tomar decisões e agir como juízes. Desta forma, faziam uma apologia contra a ideologia comunista, pois consideravam como comunistas todos aqueles que afirmavam que o distanciamento entre os países desenvolvidos para com os subdesenvolvidos era um agravante maior do que o próprio comunismo ${ }^{3}$. Assim, a sociedade latino-americana se tornava mais dependente de países desenvolvidos e as nações pobres com grande defasagem em níveis culturais e econômicos. As nações pobres vão ficando cada vez mais defasadas em níveis culturais e econômicos ${ }^{4}$.

\footnotetext{
${ }^{2}$ Para uma compreensão maior sobre a intervenção dos governos como forma de repressão nos países latino-americano, conferir: DUSSEL, E., De Medellín a Puebla, 1982, p. 237-250.

${ }^{3}$ MUÑOZ, R., Nueva conciencia de la Iglesia en América Latina, 1974, p. 70.

${ }^{4}$ GUTIÉRREZ, G., Teologia de la liberación, 1975, p. 122-123.
} 
Todo o sistema educacional na América Latina estava vinculado a um processo de alienação cultural, importado tanto dos Estados Unidos quanto da Europa ${ }^{5}$. Tal alienação teve graves interferências em disciplinas ministradas nas universidades tais como econômicas e sociais. Devida tal interferência, muitos intelectuais se sentiram na necessidade de se exilarem em outros países, muitos deles desenvolvidos ${ }^{6}$.

De fato, as transformações econômicas por que tem passado a América Latina desde o início dos anos 80 parecem seguir uma lógica de integração deste continente ao Primeiro Mundo ocidental não mais pela via do desenvolvimento. Países como o Brasil convivem hoje com uma alta taxa de inflação, uma dívida externa impagável e uma enorme recessão com a destruição sistemática do parque industrial, fruto de uma política econômica imposta pelos credores internacionais através do Fundo Monetário Internacional e do Banco do Brasil que compromete ao menos a médio prazo o desenvolvimento nacional ${ }^{7}$.

${ }^{5}$ No caso do Brasil, "durante toda a sua história, fazendo parte do mundo periférico, não encontrou em si mesmo 'o centro de decisão dos vários comportamentos que determinariam a organização de sua vida coletiva. Organizou-se como pólo passivo ou dependente de um sistema econômico político que transcende suas fronteiras'. (...) Como país periférico, o Brasil não teve possibilidade de tomar decisões como sujeito da própria história. $\mathrm{O}$ todo social bem como o seu comportamento (áreas econômicas, social, política, cultural e mesmo religiosa) fora pautado pelos interesses do centro (ou centros) em torno do qual gravitou o país. Obviamente, o centro foi primeiro constituído pela Europa colonizadora ou neocolonizadora e mais recentemente pelos Estados Unidos da América". RUBIO, A. G., Unidade na pluralidade: o ser humano à luz da fé e da reflexão cristãs. 2001, p. 57, (Coleção Teologia Sistemática).

${ }^{6}$ Medellín, Paz, 9; Podemos dizer que "uma consequência do desequilíbrio econômico em nossos países é a fuga de intelectuais para o exterior, a saída de capitais para bancos da Europa e, agora, ainda mais importante, a emigração de centenas de milhares de sul-americanos para os Estados Unidos, o Canadá, a Austrália e o Japão, com todas as consequências para a família, os valores morais e as tradições religiosas", ALMEIDA, D. L. M., O pensamento episcopal latino-americano, do Rio a Santo Domingo, in: O futuro da reflexão teológica na América Latina (CELAM), 1998, p. 15-16.

${ }^{7}$ ANDRADE, P. F. C. de. A condição pós-moderna como desafio à pastoral popular. In: REB - Revista Eclesiástica Brasileira, Petrópolis, v. 53, n. 209 , p. 99-113, 1993. 
A população que vivia tanto nas zonais rurais quanto urbanas era marginalizada dentro de um contexto social, econômico, político, cultural e religioso pela classe dominante $^{8}$. A classe dominante alienava e controlava a grande parte da população, inclusive as culturas nativas (indígenas ou mestiços) ${ }^{9}$. A integração destes povos de cultura nativa representava a destruição/exclusão da própria cultura nativa. Outro fator de exclusão era o preconceito socioeconômico quanto o próprio racismo a tais culturas, permitindo uma verdadeira segregação e discriminação de ordem social, racial, cultural e econômica. Os mais pobres, os camponeses, os negros e índios eram desprezados e foram considerados como inferiores dentro da sociedade ${ }^{10}$.

A classe dominante se tornava insensível diante da miséria e dos marginalizados. Dificilmente estavam atentos às necessidades daqueles que mais necessitavam de justiça e direitos ${ }^{11}$. Eram subversivos todos aqueles que tentavam uma mudança estrutural na política o que ameaçasse os privilégios de setores dominantes $^{12}$. O uso da força foi o método empregado para reprimir qualquer possibilidade de reação ${ }^{13}$. Na medida em que os marginalizados tomavam consciência da situação em que eles se encontravam esta se agrava cada vez mais.

\subsection{1 - Alienação que afeta a sociedade}

Diante de sistemas e instituições econômicas desumanas, muitos trabalhadores que por mais que conscientes das necessidades de transformação, viviam numa situação de dependência, chegando inclusive à escravidão física, profissional,

\footnotetext{
${ }^{8}$ Medellín, Paz, 2.2

${ }^{9}$ Um ponto-chave para a compreensão de toda Améric Latina é o fato de que este continente possuía grandes e adiantadas populações indígenas. Algumas tribos foram massacradas e desapareceram, como no Brasil, onde, de cinco milhões de indígenas no tempo da colonização, sobrevivem hoje apenas duzetos mil. Outras tiveram bastante diminuído o número de seus membros e viram destruídas suas civilizações. Mas, é preciso considerar que hoje muitas nações conservam como elemento mais significativo os descendentes desses povos indígenas, caso de Bolívia, Peru, Equador e Guatemala. ALMEIDA, D. L. M., op.cit. 1998, p. 15-16.

${ }^{10}$ MUÑOZ, R., Nueva conciencia de la Iglesia en América Latina, Salamanca: Ediciones Sígueme, 1974, p. 71

${ }^{11}$ Ibid., 1974, p. 83

${ }^{12}$ Ibid., 1974, p. 82-83.

${ }^{13}$ Medellín, Paz, 2.5 - 2.6
} 
cultural, cívica e espiritual ${ }^{14}$

A alienação presente devido à falta de conscientização e dependência da grande parte da população, gerava o seguinte quadro: falta de iniciativa e de criação de responsabilidades, e certamente a não existência de organizações populares. E, mesmo que estas existissem, eram instrumentalizadas politicamente. Da mesma forma ocorriam com trabalhadores e marginalizados urbanos (desempregados) que, carecendo de conscientização, tinham suas organizações sindicais dificultadas e muitas vezes reprimidas, sendo utilizadas como simples instrumento de dominação ${ }^{15}$. Até mesmo, as organizações populares, muitas vezes eram manipuladas por políticos em vista de interesses próprios ou de uma minoria ${ }^{16}$.

Trabalhos em regime de escravidão, já de princípio, impossibilitava o exercício da iniciativa e de responsabilidade. Um tratamento desumano e injusto recebia o trabalhador, principalmente o camponês mais humilde, o negro e o indígena, considerados inferiores. Para levar uma vida digna, os salários eram insuficientes. A capacidade criadora não era desenvolvida e nem reconhecido dentro de uma organização no trabalho. Não havia estabilidade de emprego, tão pouco a participação da empresa em vista das necessidades do trabalhador ${ }^{17}$. Aos trabalhadores competia somente vender sua força de trabalho como mercadoria, como - máquinas de produção.

Tal sistema de trabalho foi desenvolvendo no trabalhador um sentimento de inferioridade, insegurança e frustação. Se não bastasse à condição de trabalho ter se tornado um processo de servidão, o operário era conduzido a um sistema de promoção individualista de produção, ou seja, o operário padrão. Assim, a condição

\footnotetext{
${ }^{14}$ Medellín, 1.11

15 GUTIÉRREZ, G., Teologia de la liberación, Salamanca: Ediciones Sígueme, 1975, p. 51, Desarrollismo pasó así a ser sinónimo de reformismo y modernización. Es decir, de medidas tímidas, ineficaces a largo plazo, cuando no falsas y finalmente contraproducentes para lograr una verdadera transformación. Los países pobres toman conciencia cada vez más clara de que su subdesarrollo no es sino el subproducto del desarrollo de otros países debido ao tipo de relación que mantienen actualmente con ellos. Y, por lo tanto, que su propio desarrollo no se hará sino luchando por romper la dominación que sobre ellos ejercen los países ricos.

${ }^{16}$ MUÑOZ, R., Nueva conciencia de la Iglesia en América Latina, Salamanca: Ediciones Sígueme, 1974, p. 34-35.

${ }^{17}$ Ibid., 1974, p. 81-82, 86.
} 
do trabalhador foi de opressão das liberdades e dos direitos dos trabalhadores, impedindo assim a valorização do ser humano e a dignidade humana.

Em Puebla, a Igreja pode perceber tendências que desde Medellín desafiavam a atividade pastoral: a modernização como força de crescimento econômico, a urbanização de todo o Continente e o apoio de técnicas de estruturas econômicas, politicas e militares. Por outro lado, o empobrecimento e a crescente exclusão das grandes maiorias da população latino-americana de vida produtiva ${ }^{18}$.

A situação apresentada acima acentua o processo de alienação produtivo que inúmeros trabalhadores já sofreram tanto do campo quanto da cidade. Tal situação desencadeia consequências que despontam no subemprego, desemprego e até mesmo na exclusão do mercado de trabalho ${ }^{19}$.

Desta forma, os trabalhadores viviam em condições das quais eram submetidos em sistemas de comércio que os enganavam e os exploravam, não havendo segurança e nem moradia fixa, pois estavam dependentes de uma má remuneração e longe de usufruir de seus próprios direitos como trabalhador ${ }^{20}$. Tanto os desempregados quanto os subempregados, devida à falta de estabilidade, viviam numa constante insegurança, em que eram submetidos a frios cálculos econômicos ${ }^{21}$.

Era evidente que um grande abismo crescia entre ricos e pobres. Enquanto uma minoria se enriquecia, a grande maioria da população viva na miséria, sem condições suficientes para ter uma vida decente. O documento de Puebla acentua que a situação de pobreza na América Latina era a mais devastadora e humilhante flagelo em que se expressava na mortalidade infantil, moradia inadequada, nos problemas de saúde, no baixo salário, desemprego, subemprego e instabilidade no trabalho. Puebla afirma que

\footnotetext{
${ }^{18}$ Puebla, 1207

${ }^{19}$ Centesimus Annus, 15 ; No caso do Brasil, "a situação no meio rural se deteriorou. Expansão da agricultura extensiva para a exportação, além de agredir o meio ambiente, expulsou de sua terra os pequenos produtores, criando um grande proletariado rural, explodindo a violência no campo e o fenômeno migratório. Esta rápida transformação ocorrida no campo tem produzido muitas vezes um fenômeno de forte desintegração cultural que acompanha a acelerada migração interna seja do Sul em direção a Amazônia Legal seja do Nordeste em direção a São Paulo e Rio de Janeiro.” ANDRADE, P. F. C., v. 53, n. 209 , p. $99-113,1993$.

${ }^{20}$ Puebla, 35

${ }^{21}$ Puebla, 36-37
} 
a situação acima apresentada era resultado das estruturas econômicas, sociais e políticas presente na sociedade ${ }^{22}$.

É por isso que a Igreja na América Latina se apresenta como solidária no mundo do trabalho, procurando defender os trabalhadores explorados pelo sistema capitalista $^{23}$.

A rapidez do crescimento demográfico, a mecanização presente no campo e a modernização das indústrias na cidade, fizeram que aumentasse rapidamente o desemprego e a miséria na sociedade. Era nas periferias das cidades que este fenômeno se tornava mais agravante e comum ${ }^{24}$.

As indústrias só conseguindo produzir em altos custos, pois o consumo era restrito somente as classes de nível mais elevadas, diminuía assim o seu ritmo de crescimento e agravava em muitas regiões o desemprego, o que consequentemente aumentava a miséria e a necessidade de emigração ${ }^{25}$.

Devido o aumento da população e em determinadas regiões o aumento da mecanização, era visível no campo à falta de trabalho ou de um salário que fosse estável, fazendo com que muitos jovens optassem por um êxodo rural. O êxodo rural permitia um afastamento da família e a desagregação desta. Muitas vezes, para poder trabalhar, muitos aceitam qualquer valor como salário ou qualquer condição de trabalho. Tais problemas afetavam particularmente as populações marginalizadas da sociedade em que o emprego não era estável e viviam em completa insegurança ${ }^{26}$.

Era de se notar que grande parte da população latino-americana tanto do campo quanto da cidade vivia marginalizada na sociedade. Não competia a população a participação dos bens de produção econômica, e nem em decisões pertinentes a

\footnotetext{
${ }^{22}$ Puebla, 28-30

${ }^{23}$ GUTIÉRREZ, G., Teologia de la liberación, 1975, p. 168.

${ }^{24}$ MUÑOZ, R., Nueva conciencia de la Iglesia en América Latina, Salamanca: Ediciones Sígueme, 1974, p. 51.

${ }^{25}$ Ibid., 1974, p. 53-54.

${ }^{26}$ Ibid., 1974, p. 36.
} 
política $^{27}$.

A impotência e a dependência daqueles que se encontravam marginalizados fizeram com que estes se sentissem desamparados pelas instituições existentes. Dentro a um processo de passividade, da qual não tinham condições de se livrar, cresciam nestes que estão à margem da sociedade, um sentimento de agressividade. Assim, percebemos a origem da violência que tem crescido em toda a América Latina $^{28}$.

A população era marginalizada politicamente e podia-se entender a democracia apenas de uma forma teórica. As autoridades políticas, juntamente com seus partidos, não representavam a sociedade, mas sim as oligarquias políticas, empresariais, militares ou sindicais, privilegiando os interesses de pequenos grupos da elite ${ }^{29}$.

Programas promocionais e impostos de forma paternalista foram desenvolvidos pelo governo, na intenção de manter a ordem por meio da repressão e do terror militar e político. Todos os fatores da política configuravam para uma situação de instabilidade e artificialidade, sob o signo da insegurança. As ditaduras militares, em muitos países da América Latina, suprimiam os direitos de cidadão, como também

${ }^{27}$ La mayorías de nuestras poblaciones viven marginadas de la sociedad. No participan de sus bienes ni de sus servicios; no participam tampoco em las decisiones comunes, ni siquiera en las que los afectan más directamente. Esto vale tanto de los sectores rurales como de los urbanos. La población marginal urbana está formada em su mayoría por emigrantes rurales. Ellos sufren el desarraigo y suelen perder los valores positivos de la vida del campo en el torbellino de la civilización urbana. Sufren de inadaptación, al impacto de las estructuras sócio-culturales de los centros industriales, que son antagónicas respecto a las del campo. No pueden o no saben organizarse, expressar su opinión, ni por lo tanto participar de las decisiones. La psicología del marginado es de dependencia e impotencia. Siente que las instituciones existentes no son para él. Permanece pasivo ante el progreso. Tiene poca conciencia de la 'clase' oprimida, pero se alimenta em él uma agresividad latente, Id., 1974, p. 37-38.

${ }^{28}$ Existe la violencia de la opresión: dentro de los países desarrollados, dentro de los países subdesarrollados (con la diferencia de que en éstos las oligarquías están al servicio del dominador), y la más terrible: la que los países desarrollados ejercen en los subdesarrollados, oprimidos, dominados, DUSSEL, E., Historia de la Iglesia en America Latina, 1992, p. 277.

${ }^{29}$ No Brasil, "o poder aquisitivo de grande parte da populaçãotem decrescido progressivamente, sendo que hoje, com o contexto fortemente recessivo, as greves e as paralisações parecem produzir poucas conquistas e exercer pouca pressão. $\mathrm{O}$ pagamento da gigantesca máquina burocrática estatal e o peso da dívida externa e interna levaram ou forçaram a opção pela redução dos investimentos básicos na área da educação, da saúde, da habitação, enquanto a população caminha para ultrapassar 150 milhões. Neste contexto surge o fenômeno dos 'meninos de rua', sendo calculado hoje em mais de 10 milhões o número de crianças que perambulam abandonadas pelas cidades, em uma situação dramática de carência e expostas a todo tipo de violência, transformando-se por sua vez, reativamente, em sujeitos de violência." ANDRADE, P. F. C. de., v. 53, n. 209 , p. 99-113, 1993. 
partidos políticos e a liberdade de imprensa ${ }^{30}$.

Uma nova geração se formava na sociedade e via-se a importância de um compromisso na conscientização da população. Nasciam os movimentos sindicais e universitários, a consciência política crescia pela organização de alguns grupos de intelectuais, mostrando que esta consciência descobre pouco a pouco o modo de situar-se de maneira original, e adequada ao ritmo da evolução e do desenvolvimento necessário e integral. E juntamente a esta nova perspectiva, podemos incluir a massa de trabalhadores industriais, como também os pobres camponeses, os universitários e professores, todos em busca de uma nova forma de pensar na sociedade latinoamericana. $^{31}$

$\mathrm{O}$ abuso de poder e a violação dos direitos humanos ${ }^{32}$ eram alimentados pelo caráter totalitário e/ou autoritário dos regimes de forças promovidas pelas ideologias da segurança nacional. Estas ideologias, apoiadas por características elitistas, sendo determinadas por modelos econômicos e políticos, suprimiam a atuação ampla do povo nas decisões políticas ${ }^{33}$. A segurança nacional conferia a tutela do povo por elites de poder, militares e políticas, fazendo com que acentue uma desigual participação no desenvolvimento social ${ }^{34}$.

Não era do interesse do governo entender os problemas socioeconômicos da

${ }^{30}$ De 1930 a la década de 1960-1970 se cumple toda una etapa de la historia política y económica de Latinoamérica. La Segunda Guerra Mundial viene a modificar o acentuar todavía más el sistema tradicional de división internacional de trabajo. «La demanda internacional de productos primarios pierde su dinamismo como reflejo de la propia evolución de las estructuras de los países industrializados». El descenso del precio de las materias primas exportables a los países desarrollados produjo una incipiente industrialización, que permitió disminuir las importaciones. Esto produjo de inmediato una creciente clase proletaria y la pérdida correlativa de poder de la oligarquía. Los gobiernos pudieron llevar a cabo la industrialización gracias a un proceso inflacionario acelerado. Ello significó una profunda inestabilidad social. Por tanto no podía extrañar la aparicion de numerosas dictaduras o gobiernos reformistas de tipo militar: en 1945 se produce un golpe militar en Brasil; en dicho año asume el poder Perón en Argentina; en 1948 establece su dictadura Odría en Perú; en 1952, Batista en Cuba y Pérez Giménez en Venezuela; en 1953, Gustavo Rojas Pinilla en Colombia, y en 1954 Castillo Armas en Guatemala y Stroessner en Paraguay. Tiempo antes gobernaba dictatorialmente Trujillo en Santo Domingo, y Anastasio Somoza en Nicaragua, DUSSEL, E., Historia de la Iglesia en America Latina, 1992, p. 208-209.

${ }^{31}$ DUSSEL, E., América Latina y conciencia Cristiana, 1970, v.8, p. 43-44, (Colección IPLA).

${ }^{32}$ LACALLE, F. S., La defensa de la vida y los derechos humanos, in: Iglesia in América, Al encuentro de Jesucristo vivo, 2001, p. 235.

${ }^{33}$ MUÑOZ, R., Nueva conciencia de la Iglesia en América Latina, 1974, p. 56-57.

${ }^{34}$ Puebla, 49, 547, 549 
sociedade, e muito menos as condições de vida dos trabalhadores. Não havia preocupação se a produção correspondia ou não as necessidades das maiorias. Não havia proteção dos direitos e da liberdade dos mais necessitados e desvalidos, os seus direitos eram esquecidos. A administração judicial nos países latino-americanos era deficiente, irregular e com privilégios a uma minoria. Aos trabalhadores e aos mais pobres eram conferidas longas e burocráticas tramitações. Caso um operário, camponês e um indígena fossem presos, os processos eram lentos, e os cárceres desumanos ${ }^{35}$.

\subsection{2 - Alienação e passividade social}

Vemos que a situação ocorrida ao povo latino-americano é devido à sua passividade ao viver culturalmente alienado pelas estruturas políticas. O povo acostumado com atitudes tais como: indolência, lentidão, à falta de ocupação e de disciplina, não passa a desenvolver princípios de conscientização moral e senso crítico.

Devido aos grandes problemas enfrentados no campo do trabalho por causa da opressão e insegurança por uma vida melhor, a população se via, em vista de sua resignação passiva, diante do sofrimento e miséria, o seu conformismo alimentado por uma religiosidade alienante. Prevalecia no povo a imagem de um Deus paternalista quando, que tem a solução de tudo, ou de um Deus arbitrário e vingador (castigador), quando os problemas não eram resolvidos. Havia a tentativa em solucionar ou explicar tudo a partir de uma espera ou iniciativa divina. A imagem de Cristo sofredor se tornou corrente e a sociedade começou a se identificar com ele ${ }^{36}$.

No documento de Puebla acentua as dificuldades relacionadas à religiosidade popular. Surgem manifestações supersticiosas, magia, ritualismo, a falta de

\footnotetext{
${ }^{35}$.MUÑOZ, R., Nueva conciencia de la Iglesia en América Latina, 1974, p. 41.

${ }^{36}$ Ibid., 1974, p. 78
} 
informação e ignorância reduz a fé a um mero contrato de relação com Deus ${ }^{37}$.

Assim, os trabalhadores se viam dominados por um sentimento de insegurança vinculado tanto aos valores morais quanto religiosos. Sentiam muitas vezes pecadores e isolados diante de um Deus que pode castigar e também oprimir. Procuravam no culto e nas devoções populares uma forma de amenizar os sofrimentos, angustias e fracassos. O povo vivia praticamente sem esperança ou de fato, a esperança era a única forma de expressar a humanidade que lhe restava ${ }^{38}$.

Uma das situações existentes mais presentes na América Latina e é muito acentuado nos documentos do CELAM é a distancia muito grande entre os ricos e os pobres. Os países latino-americanos foram compreendidos como aqueles que oferecem mão de obra para o trabalho, enquanto nos países desenvolvidos concentravam-se as riquezas. A disparidade entre a riqueza e a pobreza propiciou uma relação de dependência econômica, política e cultural. Dentro fenômeno do neocolonialismo, os países da América Latina não eram donos de seus bens e nem de suas decisões econômicas ${ }^{39}$.

Entre a pobreza de nossos países e a riqueza dos países desenvolvidos ocidentais existe não só um agudo contraste, senão também uma relação de dependência. Nossos países dependem economicamente das metrópoles industriais, são explorados por ela. A dependência econômica acarreta igualmente a dependência política e cultural: é o fenômeno do neocolonialismo. A dependência estrangeira de nossa economia é uma das principais causas do cunho instável e artificial de nossa situação política ${ }^{40}$.

Na própria história da América Latina, podemos encontrar uma sucessão de formas de colonialismo: já de princípio temos a presença da Espanha e de Portugal e posteriormente da Inglaterra e dos Estado Unidos. Aquilo que chamamos de

37 Os aspectos negativos são de origens várias. De tipo ancestral: superstição, magia, fatalismo, idolatria do poder, fetichismo e ritualismo. Por deformação da catequese: arcaísmo estático, falta de informação e ignorância, reinterpretação sincretista, reducionismo da fé a um mero contrato na relação com Deus. Ameaças: secularismo difundido pelos meios de comunicação social, consumismo, seitas, religiões orientais e agnósticas, manipulações ideológicas, econômicas, sociais e políticas, messianismos políticos secularizados, perda de suas raízes e proletarização urbana, em conseqüência das transformações culturais. Podemos afirmar que muitos desses fenômenos são verdadeiros obstáculos para a evangelização, Puebla, 456

${ }^{38}$ MUÑOZ, R., Nueva conciencia de la Iglesia en América Latina, 1974, p. 41.

${ }^{39}$ Ibid., 1974, p. 65.

${ }^{40}$ Ibid., 1974, p. 44. 
independência política, conquistada no início do século XIX, não corresponde necessariamente a uma independência econômica. Com relação à metrópole ibérica houve um rompimento, no entanto, não foi possível uma autonomia em relação ao sistema capitalista internacional. Apesar de todos os esforços e do desejo das partes para que houvesse a independência, os interesses neocolonialistas não permitiram que a América Latina se desenvolvesse como pátria comum ${ }^{41}$.

\subsection{3 - O Subdesenvolvimento na América Latina}

Um dos grandes fatores do subdesenvolvimento nos países latino-americanos foi atribuído ao rápido crescimento demográfico, devido não menos pela taxa de nascimento e nem pela taxa de mortalidade, mas sim pelo crescente índice de longevidade. Mas o fator demográfico tinha seus problemas e se tornavam cada vez mais críticos. As más condições socioeconômicas e culturais permitiam que as estruturas sociais se tornassem cada vez mais injustas, tendo em vista que para o crescimento na América Latina o desenvolvimento demográfico teve um fator culminante ${ }^{42}$.

Um dos grandes problemas relacionado ao desenvolvimento demográfico é o crescimento desordenado das cidades. Tal situação torna cada vez mais difícil a vida nas grandes cidades, para muitos faltam alimentos, moradia, hospitais e escolas. A população carente aumentava consequentemente suas misérias e angústias ${ }^{43}$.

O aumento da população era visto para o capitalismo como um sinal negativo. Com efeito, o capitalismo focava somente em critérios político-econômicos, fazendo esquecer aspectos sociais, culturais, psicológicos e até mesmo ético-religiosos. Era imposto o controle massivo de natalidade como condição para a mudança das estruturas em vista do desenvolvimento ${ }^{44}$.

\footnotetext{
${ }^{41}$ Ibid., 1974, p. 66.

${ }^{42}$ Medellín, Família e Demografia, 3.8

${ }^{43}$ Puebla, 71

${ }^{44}$ MUÑOZ, R., Nueva conciencia de la Iglesia en América Latina, 1974, p. 51
} 
A passividade era também outro fator de problema na sociedade latinoamericana, pois esperavam tudo do patrão, das autoridades. Círculos viciosos da miséria eram presentes como o alcoolismo e hábitos machistas ${ }^{45}$. É claro que tudo isso não mais é do que a consequência daquilo que a população já sofria devido à exploração.

A exploração se tornou a causa da injustiça em que ameaçava e negava a paz. $\mathrm{O}$ subdesenvolvimento se torna uma condição causada por um conjunto de fatores associados, tais como: econômicos, políticos, culturais e espirituais ${ }^{46}$. Assim, se dividia a maioria da população, considerada a mais pobre daquela minoria, os ricos. Mas a divisão não era somente por bens matérias, mas também enquanto dignidade humana. O subdesenvolvimento social era, ao mesmo tempo, causa e consequência do subdesenvolvimento econômico ${ }^{47}$.

O subdesenvolvimento é resultado da expansão capitalista de grandes potências industriais e de setores privilegiados de países latino-americanos. Expansão e prosperidade que tinham como apoio a exploração da classe mais baixa da população $^{48}$.

Para os países mais desenvolvidos, o interesse maior estava principalmente no aumento da produção e no desenvolvimento da tecnologia estimulando o lucro. Esta ideologia estava preocupada unicamente com os meios de produção de forma que bastasse apenas produzir e melhor produzir de acordo com um planejamento e

${ }^{45}$ Ibid., 1974, p. 40, 52

${ }^{46}$ É grande a riqueza natural de minerais, terra, vegetação, rios, mares. Isso poderia garantir um futuro de bem-estar. Mas, primeiro, houve uma continuada exploração do continente pelas nações colonizadoras, e mais tarde pelas nações do Primeiro Mundo e por grandes multinacionais. Por causa da necessidade do trabalho e por falta de políticas adequadas, numerosos contingentes da população foram obrigados a migrar internamente para as cidades, assim como a passar de um lado a outro das fronteiras. Como consequência, em menos de cinquenta anos um continente rural transformou-se em urbano, com excessiva densidade populacional em cidades como Cidade do México (20 milhões), São Paulo (17 milhões), Buenos Aires, Rio de Janeiro e outras. Essas migrações criaram problemas quase insolúveis de sobrevivência, trabalho, habitação e estabilidade da vida familiar, ALMEIDA, D. L. M., O pensamento episcopal latino-americano, do Rio a Santo Domingo, in: O futuro da reflexão teológica na América Latina (CELAM), 1998, p. 16.

${ }^{47}$ MUÑOZ, RONALDO, Nueva conciencia de la Iglesia en América Latina, Salamanca: Ediciones Sígueme, 1974, p. 52-53; Sollicitudo rei socialis, 22

${ }^{48}$ Id., 1974, p. 53-54 
tecnologia para que o povo fosse integrado como produtor-consumidor ${ }^{49}$.

Não se pode negar que por uma situação de subdesenvolvimento, a realidade da sociedade latino-americana tem sido afetada profundamente em sua dignidade humana. Diversos setores da população têm sido perturbados por inseguranças e privações de forma a não satisfazer suas necessidades básicas. Ao viver na pobreza, privados de bens e de serviços sociais, muitas pessoas viviam e ainda vivem em extrema pobreza, ignorância e numa situação de angustia opressão.

\subsection{4 - A força do sistema capitalista}

É evidente que a situação de pobreza na América Latina tem como responsável o sistema capitalista. Ao considerar o lucro, como motor importante para o progresso econômico, este sistema acentuava uma concorrência como lei de suprema economia e princípio de propriedade privada dos meios de produção. Este sistema considerava o capital como o fim e o homem como o meio. Havia uma subordinação dos direitos humanos em vista dos resultados econômicos ${ }^{50}$. O capital era a única fonte de direitos em que a absolutização do econômico era a fonte de domínio do homem sobre seus semelhantes. O sistema capitalista não tem como principio perceber a dignidade do homem e seus valores pessoais, mas sim tende a valorizar o acumulo de capital nas mãos de uns poucos. Tal sistema permite o enriquecimento e a imposição de regras

${ }^{49}$ Los beneficiários de este sistema son aquellos que poseen la clave del ciclo, y éstos son: las oligarquías criollas capitalistas y burguesas, y los capitales extranjeros, DUSSEL, E. América Latina y conciencia Cristiana, 1970, v.8, p. 39, (Colección IPLA).

${ }^{50}$ Dussel considera que el capitalismo es la expresión de una ética negativa ya que pone al lucro antes que a los seres humanos. La meta fundamental de la producción capitalista es el 'lucro', la creación de la riqueza para el capitalismo. Por tanto, el capitalismo constituye una inversión y tergiversación de la póiesis y la económica. Al hacer del lucro la meta de la producción, el capitalismo cae em el economicismo - el lucro usurpa el lugar de la realización humana que debe ser el verdadeiro motivo de la producción no se lleva a cabo con el fin de satisfacer las necesidades de la mayoría - los pobres, el pueblo. En el capitalismo ...todo producto es producido para cumplir primeramente no una necesidad, sinon para ser mediación de aumento de capital, de ganancia. En el capitalismo se da una doble tergiversación: 1 - el trabajador es privado del producto de su trabajo - alienado - a la vez que - 2 - el trabajo del trabajador se convierte en acumulación de riqueza - capital - para el capitalista (...). Por tanto, el capitalismo exalta al interés ego-céntrico-individualismo egoísta antes que la preocupación por los intereses de los demás, antes que la liberación alternativa RUANO, E. M., La filosofia de la liberación, 1995, p. 120 
injustas. O sistema empresarial na América Latina estava relacionado a este sistema capitalista, em que era válido a lei do mais forte, sobre a propriedade dos meios de produção e sobre a finalidade da economia. Não tinha como objetivo atender o bem comum, mas sim o bem-estar de uma minoria. Havia uma diferença muito grande naquilo que o trabalhador produzia para aquilo que ele necessitava para a própria subsistência, pois aquilo que produzia acabava ficando nas mãos de poucos ${ }^{51}$.

O capitalismo é, de fato, um sistema extremamente materialista, em que era capaz de oprimir os mais pobres e trabalhadores. Não foi possível gerar na América Latina um crescimento econômico de acordo com as necessidades da população.

O desempenho econômico dos países latino-americanos nos últimos anos mostra também vazios e insuficientes que precisam ser superados, principalmente quando isso é codição fundamental para conseguir a melhora do bem-estar social. A insuficiência dos processos de recuperação e crescimento econômico na região afeta esse bem-estar de maneira direta e complexa e se traduz em aumento de desemprego, persistente situação de salários defasados, déficit habitacional, redução dos serviços sociais e perda de sua qualidade, aumento dos índices de criminalidade e insegurança, deterioração das condições ambientais ${ }^{52}$.

${ }^{51}$ MUÑOZ, R., Nueva conciencia de la Iglesia en América Latina, 1974, p. 56; O neoliberalismo econômico, que com novos e poderosos instrumentos, está desenvolvendo uma economia globalizada, reina absoluto neste início do século e do milênio. (...) esta nova modalidade de sociedade envolve, naturalmente, uma visão do ser humano que desafia diretamente a antropologia cristã. De maneira muito sintética, enumeramos algumas características da nova sociedade que mais diretamente repercutem na visão que auto-possuem homens e mulheres integrados na sociedade: 1 . O ser humano é radicalmente instrumentalizado, reduzido que é a mera função do mercado; o ser humano é visto simplesmente como consumidor potencial; 2. Uma competição feroz orienta a vida de homens e mulheres, deixando de lado valores tais como a solidariedade, a colaboração, entre outros; 3 . Em continuidade com a ideologia da sociedade industrial, predominam os valores próprios de um individualismo associal: procura da própria satisfação, quanto mais melhor (lucro maior, prazer maior etc); 4. Continua fortemente presente o racionalismo tecnocrático tão criticado pelas correntes pósmodernas. O mercado globalizado tem suas regras próprias, com seu dinamismo próprio. Trata-se de leis que devem ser obedecidas rigorosamente se se quer participar da economia globalizada. A desobediência significaria a exclusão; 5 . O ser humano é visto numa perspectiva fortemente elitista. Valioso, econômica e socialmente, é só o homem ou a mulher que têm a capacidade para consumir nesse maravilhoso mercado mundial. (...). 6. Naturalmente, quem não pode consumir é deixado de lado, faz parte da massa descartável. Excluídos são todos aqueles, pessoas, grupos, regiões etc. que não podem ser integrados na Sociedade em Rede; 7. Desenvolve-se uma cultura internacional, que tende a desvalorizar as expressões culturais nacionais ou regionais ou a integrá-las apenas como elementos folclóricos; 8. Mas, por outra parte, desenvolve-se uma cultura internacional audiovisual, substituindo a civilização do alfabeto (...); 9. O espaço de fluxos tende a deixar de lado o enraizamento local e o tempo virtual e a suplantar o tempo cronológico. As consequências destas transformações sobre o ser humano são ainda, em grande parte, imprevisíveis. RUBIO, A. G., Unidade na pluralidade: o ser humano à luz da fé e da reflexão cristãs. 2001, p. 49-50, (Coleção Teologia Sistemática).

${ }^{52}$ IGLESIAS, E., A América Latina diante do terceiro milênio: tendências e desafios, in: $O$ futuro da reflexão teológica na América Latina, 1998, p. 71-72. 
As denúncias desta estrutura de exploração se tornaram a esperança cristã da população em vista de mundo mais solidário e igualitário. Tais denúncias vieram à tona por meio de documentos emitidos pela própria Igreja e de organizações populares latino-americanas ${ }^{53}$. A situação de miséria em que muitas pessoas se encontravam, chamou atenção à responsabilidade social e a comprometimentos de ação transformadora de grupos de apoio às causas humanitárias.

Com efeito, com apoio da Igreja e de entidades em que pudessem promover uma ação transformadora, os latino-americanos poderiam estar mais conscientes de seus compromissos em frente a uma situação de miséria e injustiças, começar a empenhar forças para uma mudança de situação ${ }^{54}$. Desta forma, é percebida a imagem de Deus como fundamento ao combate a pobreza e opressão. Trata-se de uma opção fundamental que revela a radicalidade da fé cristã. A imagem de Deus que dá preferência aos mais pobres se torna o fundamento eclesial para aproximar-se dos mais necessitados 55 .

Desde Medellín e Puebla a situação social vigente na América Latina foi caracterizada não só pela grande extensão da miséria humana, mas também pela radical injustiça, edificada sobre a exploração daqueles mais pobres e necessitados.

Tudo o que era produzido na América Latina tinha relação com o comércio estrangeiro. Tal relação fazia com as riquezas naturais se tornassem mais baratas e a compra de produtos industrializados fossem cada vez mais caras. ${ }^{56}$. Muitas empresas nacionais passavam a ser administradas por capitalistas estrangeiros em busca de lucros, enquanto que as empresas estrangeiras estavam isentas de impostos favorecendo mão-de-obra barata. Assim, aumentava cada vez mais o empobrecimento e impedia o desenvolvimento ${ }^{57}$. Os empréstimos feitos aos países desenvolvidos estavam condicionados as medidas econômicas e sociais de exploração dos

\footnotetext{
${ }^{53}$ Puebla, 92

54 Puebla, 518

55 Puebla, 169, 475

${ }^{56}$ Este imperialismo internacional do dinheiro introduz no mundo uma verdadeira luta de classes, explorando a povos inteiros. Tinha-se a pretensão em manter o sistema capitalista no mundo, que é um sistema de exploração. MUÑOZ, R., Nueva conciencia de la Iglesia en América Latina, 1974, p. 68.

57 Ibid. 1974, p. 68.
} 
trabalhadores de forma a beneficiar muito mais os poderosos do que os empobrecidos.

O próprio documento de Puebla tem uma visão crítica da dependência econômica, tecnológica, política e cultural na América Latina. A preocupação maior das multinacionais era por seus próprios interesses a custa do esforço dos trabalhadores $^{58}$. O problema da dependência se deve ao fato de que a riqueza de alguns propiciava a pobreza de muitos, aumentando a distancia entre ricos e pobres. A prosperidade dos poderosos se fundou na exploração e na miséria dos fracos ${ }^{59}$. A pobreza, foi interpretada no documento de Puebla, como pecado na forma de uma exploração causada pelos sistemas de organização da economia e da política nacional.

Desta forma, o interesse desenfreado pelo dinheiro fez com que surgisse uma verdadeira luta de classes, explorando os povos em busca de capital. Os países mais desenvolvidos começaram, por sua vez, a sustentar o envio de armamentos para desarticular conflitos internos em países subdesenvolvidos, ao invés de incentivar o desenvolvimento. Muitas alianças estabelecidas tanto economicamente quanto politico-militares foram à base de ditaduras militares em apoio à segurança, à ordem $\mathrm{e}$ ao serviço do capitalismo.

\footnotetext{
${ }^{58}$ Puebla, 1264

59 DUSSEL, E., De Medellín a Puebla, São Paulo: Loyola, v. II: De Sucre à crise relativa do neofascismo - 1973-1977, 1982, p. 241
} 
Nos países latino-americanos, aumentava enormemente as desigualdades sociais. A ostentação, o luxo e até mesmo o desperdício era privilégio de uma pequena minoria, como nos países mais desenvolvidos, por outro lado, os pobres viviam com salário de miséria. Era evidente o distanciamento entre os ricos e os pobres. O desenvolvimento econômico e tecnológico favorecia somente o aumento de riquezas de uma minoria, pondo à margem a maioria da população mais pobre. Assim, verificavam-se enormes desigualdades entre regiões mais pobres e outras muito mais desenvolvidas ${ }^{60}$.

Puebla percebeu a dificuldade da classe mais pobre na América Latina evidentemente impressa no rosto de crianças que passam fome e que sem expectativas não conseguiam um padrão de vida sustentável ${ }^{61}$. Os jovens não encontravam oportunidades de emprego e de capacitação suficientes, para que pudessem encontrar um lugar na sociedade ${ }^{62}$. Os indígenas e afro-americanos eram considerados os mais pobres dos pobres e viviam bem mais a margem da sociedade, em condições extremamente desumanas ${ }^{63}$. Aqueles que viviam no campo eram dependentes de um sistema de exploração e de enganação em que não tinham nem mesmo a terra onde trabalhavam como garantia de moradia, muitas vezes, eram mal remunerados e não tinham condições em reivindicar seus próprios direitos. E, por fim, os desempregados que eram submetidos a baixíssimos salários permitindo-lhes sofrer pela carência de bens materiais ${ }^{64}$. Assim, era visível a injustiça na distribuição

\footnotetext{
${ }^{60} \mathrm{O}$ ponto que mais chama a atenção é a enorme desigualdade social, que separa, mais que em outros continentes, os inúmeros empobrecidos de uns poucos excessivamente ricos. Basta lembrar que, no Brasil, a metade das terras está mnas mãos de $1 \%$ dos proprietários. Hoje, por causa da política neoliberal que entrou rapidamente em nossos países, a situação agravou-se, pois não há apenas empobrecidos, mas também marginalizados, excluídos das condições mínimas de sobrevivência. Não se trata de temer as reinvidicações dos trabalhadores que sempre podem organizar-se, por exemplo, para melhorar seus salários, mas de constatar que os excluídos não são, por enquanto, capazes de reconhecer sua dignidade e organizar-se. ALMEIDA, D. L. M., O pensamento episcopal latinoamericano, do Rio a Santo Domingo, in: O futuro da reflexão teológica na América Latina (CELAM), 1998, p. 17.

${ }^{61}$ Puebla, 31

${ }^{62}$ Puebla, 33

${ }^{63}$ Puebla, 34

${ }^{64}$ Puebla, 35-38
} 
das terras, dos salários e da própria habitação ${ }^{65}$.

Outra forma de alienação podemos encontrar a partir do Mass Media. Por falta de conscientização e senso crítico a pessoa pode se sentir alienada, inclusive, por determinadas informações. Informações estas desenvolvidas pelos Meios de Comunicação Social.

Não se pode negar que os meios de comunicação se tornaram hoje uma das ferramentas mais importantes para a transmissão de uma mensagem. Ao se encontrar ao alcance de todos, os diversos meios de comunicação possuem a força de massificar ou favorecer um particular. A possibilidade em aproximar as pessoas da cultura de diversos povos, e permitir também, que às pessoas se tornem mais solidárias, fez com que os meios de comunicação se tornassem uma das grandes conquistas da modernidade.

Nas conferências episcopais de Medellín e de Puebla podemos perceber aspectos positivos e negativos dos meios de comunicação social. De princípio, vemos que, positivamente os MCS contribuem na percepção das grandes massas suas condições de vida, possibilitando aspirações e exigências de transformações sociais ${ }^{66}$. Na conferência de Puebla os MCS são apresentados como fatores de comunhão e de integração na América Latina, assim como, para a expansão e democratização da cultura $^{67}$.

Não obstante, os documentos de Medellín e Puebla acentuam também aspectos negativos. Um dos aspectos é o vínculo dos MCS a grupos políticos e econômicos, tanto nacionais quanto estrangeiros, em que o interesse maior é manter o status quo social $^{68}$. Puebla, por sua vez faz denúncia ao controle e a manipulação dos meios de comunicação pelos poderes políticos e econômicos, na intenção em manter o status

65 "Esta injustiça era verificada na distribuição das terras, dos salários e da habitação". MUÑOZ, R., Nueva conciencia de la Iglesia en América Latina, 1974, p. 76.

${ }^{66}$ Medellín, Meios de Comunicação Social, 1.2

${ }^{67}$ Puebla, n. 1068, 1069

${ }^{68}$ Medellín, Meios de Comunicação Social, 1.2.1 
$q u o$, fazendo com que crie uma relação de dependência-dominação ${ }^{69}$. Por se constituir um flagrante da violação dos direitos individuais, o documento também faz denúncia à exploração de sentimentos, violência e sexo com objetivos consumistas ${ }^{70}$

Em vista de tais circunstancias, os MCS apresentam uma influência deformadora e alienante principalmente aos jovens e a família de modo geral. A alienação se deve ao fato de ocultar a situação real, impondo a "cultura" do consumo, ou seja, princípios individualistas que correspondem ao conforto, prestígio e ascensão de dinheiro.

O objetivo principal dos MCS deveria ser na divulgação responsável de valores de vida na sociedade em que se possibilite uma cultura que aumentasse o desejo de mudança. Com os meios de comunicação, a população deveria de se tornar mais conscientizada para com os seus direitos e sentir mais solidária para com os mais necessitados $^{71}$. Mesmo correspondendo os interesses de uma minoria, os MCS surgiram como uma possibilidade de aproximar as pessoas. Nascia um processo de sociabilização, um fenômeno completamente novo e uma das conquistas da época moderna $^{72}$.

A grande parte da população não estava em condição de estabelecer um juízo crítico (evidentemente devido à má formação educacional) pelos MCS, de forma aceitar determinadas informações como se fossem verdades. Outro fator importante é o aumento de expectativas e frustações da classe mais pobre da sociedade. As aspirações cresciam mais rapidamente que as possibilidades, aumentando assim a insegurança. É pela propaganda que o sistema gerava cada vez mais novas aspirações,

${ }^{69}$ As estruturas de dominação (coloniais e neocoloniais) afetaram a consciência do ser humano, originando a consciência oprimida, caracterizada pelo fatalismo, passividade, submissão e mutismo. A desumanização é tão radical que o dominado introjeta a figura do dominador coo sendo o verdadeiro modelo de humanidade, enquanto desenvolve um profundo desprezo pelo próprio mundo. É no âmbito da consciência que se percebe com maior radicalidade o tremendo efeito desumanizante das estruturas de dominação. RUBIO, ALFONSO GARCÍA, Unidade na pluralidade: o ser humano à luz da fé e da reflexão cristãs. São Paulo: Paulus, 2001, p. 49-50, (Coleção Teologia Sistemática).

${ }^{70}$ Puebla, n. 1068, 1069

${ }^{71}$ Medellín, Meios de Comunicação Social, 1.2; 2.3

${ }^{72}$ Medellín, Meios de Comunicação Social, 1.1.1 
e ao mesmo tempo as estruturas se viam incapazes de satisfazer devidas aspirações ${ }^{73}$.

A Igreja na América Latina reconheceu a importância dos MCS para a atividade missionária, evangelizadora e a formação da consciência da sociedade, e propôs aos agentes de pastorais o conhecimento e a compreensão de tais recursos, afim de que, se adapte a respostas pastorais com a realidade da sociedade. Os MCS passaram a ser integrados a pastoral de conjunto ${ }^{74}$.

Não se pode negar que os meios de comunicação social exerceram grandes desafios, riscos, influência e/ou deformação da constituição familiar, possibilitando novas formas de pensar e modelos culturais ${ }^{75}$. No documento de Puebla ainda menciona que a Igreja na América Latina deveria dar um apreço cada vez maior aos MCS, principalmente na evangelização, promovendo seus próprios veículos de comunicação, no intuito de defender os valores cristãos e de ser voz dos pobres que estão excluídos no mundo e da própria comunicação social ${ }^{76}$.

Por fim, podemos compreender que no cotidiano de nossa vida muitos se encontram inativos, sem forças para obter uma vida digna e de respeito. Muitos se encontram alienados, por um sistema do qual os fazem perder completamente as esperanças por uma vida melhor. A alienação é fruto da desvalorização dos valores humanos em vista de um objetivo maior: ostentação, riqueza e acumulo de bens, mas não em benefício de uma maioria, mas sim de uma minoria ${ }^{77}$.

\footnotetext{
${ }^{73}$ Puebla, 62; MUÑOZ, R., Nueva conciencia de la Iglesia en América Latina, 1974, p. 115

${ }^{74}$ Puebla, $1079-1083$

${ }^{75}$ Puebla, 419, 573, 908, 1018

${ }^{76}$ Puebla, 158, 1092-1094

${ }^{77}$ Centesimus Annus, 41
} 


\section{2 - A vida política}

Na sociedade latino-americana, no que diz respeito às minorias, estavam em seu favor toda a ordem jurídica, a legislação e a administração da justiça. No entanto, não eram concedidos os devidos direitos à população e nem ao menos uma segurança por parte dos poderes públicos. A mentalidade capitalista estava enraizada nas instituições de forma a perverter e/ou a colocar os interesses individualistas acima das necessidades coletivas ${ }^{78}$.

A ordem jurídica, a legislação, a administração da justiça, perpetuam os privilégios e hegemonias das minorias. Não garantem a segurança do homem, não o protegem ante a arbitrariedade dos poderes. (...) Conquanto em geral a legislação seja conforme com os direitos humanos, em sua aplicação e na mentalidade geral há grandes deficiências. Na administração judicial existem privilégios e irregularidades: o pobre costuma não ser ouvido pela justiça, o trabalhador é vítima da tramitação burocrática, procede-se a detenções arbitrárias, os processos são lentos, nos centros policiais e penais costuma-se aplicar a tortura. O direito é usado como instrumento de opressão dos fracos ${ }^{79}$.

Os mais pobres não eram ouvidos em questões judiciais, pois na administração judicial havia irregularidades e privilégios de alguns. Os trabalhadores se tornavam vítimas de burocracias, de processos lentos e detenções arbitrárias. A tortura era a prática utilizada em centro policiais de forma a corroborar cada vez mais, para que, o direito fosse usado como instrumento de opressão dos indefesos e debilitados deste sistema injusto.

A democracia caia num vazio, pois se tornava difícil falar desta quando se percebe que na sociedade existe uma grande desigualdade econômica e social. $\mathrm{Na}$ América Latina, a liberdade da maioria era desprezada pelos privilégios do sistema, sistema este em que eram representados por oligarquias políticas, empresariais, militares e sindicais ${ }^{80}$.

Precários e sem eficiência, os serviços públicos não chegavam ao campo e nem as periferias urbanas. Devido às formalidades burocráticas, os pobres não tinham acesso a recursos necessários para uma boa qualidade de vida, fazendo com que a

\footnotetext{
${ }^{78}$ MUÑOZ, R., Nueva conciencia de la Iglesia en América Latina, 1974, p. 78

${ }^{79}$ Ibid., 1974, p. $51-52$

${ }^{80}$ Ibid., 1974, p. 81
} 
mortalidade infantil crescesse nos países latino-americanos.

Não havia uma representatividade ao bem comum por parte dos partidos políticos, mas somente interesses de pequenos grupos. A liberdade era suprimida da sociedade, impossibilitando a participação do povo. O sistema capitalista consolidado pelo governo, muitas vezes reprimia e explorava, negando até mesmo as liberdades fundamentais, tais como opinião, expressão e de senso crítico ${ }^{81}$.

Os militares, em vista de um colonialismo interno, exerciam uma pressão constante aos países latino-americanos, tendo como base uma ideologia que prega a “ordem”, "segurança", "eficácia” e "modernização". Ao alegar ineficácia e pouca expressão de partidos políticos, os golpes de estado e mesmo as ditaduras militares se apresentavam como revolucionários. No entanto, o interesse fundamental era salvaguardar apoio as classes privilegiadas ${ }^{82}$.

As Conferências de Medellín e de Puebla, por sua vez, afirmam que as forças armadas deveriam assumir sua função específica em garantir a participação, livre e responsável dos cidadãos, ao invés, de lhes por obstáculos ${ }^{83}$.

Pelos dados históricos e pelo documento de Medellín pudemos perceber a situação em que estava envolvida a América Latina em seu contexto social, econômico, político e cultural e, com efeito, a tomada de consciência dos cristãos, que se sentiram engajados no compromisso com a justiça social.

\footnotetext{
${ }^{81}$ Ibid., 1974, p. 82

${ }^{82}$ Ibid., 1974, p. 82; Em nossos povos permanece viva a herança dos movimentos de libertação em busca de autonomia política. Obstáculos quase insuperáveis imperdiram que se desenvolvesse nos países a democracia proposta nas Constituições dos Estados. A corrupção influiu negativamente em quase todos os países. Nas últimnas décadas, a presença dos militares nos governos paralisou a atuação dos políticos e estabeleceu situações de perseguição e de grandes injustiças em nome da Doutrina da Segurança Nacional. Com a intenção de impedir a penetração do comunismo, foram eliminados líderes trabalhadores e universitários. Em alguns países, como a Guatemala, houve extrema concentração de poder, já que os militares também eram membros do governo, donos de terras e banqueiros. Esses anos marcaram nossos povos com sangue e deixaram uma triste e obscura história de violação dos direitos humanos. ALMEIDA, D. L. M., O pensamento episcopal latino-americano, do Rio a Santo Domingo, in: O futuro da reflexão teológica na América Latina (CELAM), 1998, p. 17.

${ }^{83}$ Medellín, Pastoral das elites, 7.20; Puebla, 1247
} 


\subsection{1 - Insensibilidade diante dos marginalizados}

A classe dominante, sendo a mais favorecida e conservadora, se mostrava insensível diante da situação de pobreza e miséria que afligia a sociedade. Não se pode esquecer a luta contra a pobreza, assim como o ricaço e o pobre Lázaro, separado por um grande abismo, o imenso agravo comparativo entre ricos e pobres, não diminui, mas aumenta escandalosamente. Mesmo na possibilidade em promover uma ação social, esta era do tipo assistencial-paternalista. Os sistemas empresariais vinculados ao sistema capitalista não asseguravam o bem comum, senão o benefício de uma minoria. Tais sistemas, dominados pelos princípios da lei do consumo olhavam a sociedade com frieza diante da miséria que acarretava a população. A diferença entre o que o trabalhador produz e o que ele necessita para subsistirm era direcionado para a mão de uns poucos ${ }^{84}$.

A falta de conduta moral apresentada pelos políticos e pela classe dirigente fazia com que a população olhasse com desconfiança as instituições públicas. Já em Puebla se observa a crise moral inserida na sociedade: "a crise de valores morais: a corrupção pública e privada, a ganância do lucro desmedido, a venalidade, a falta de esforço, a carência de sentido social, de justiça vivida e solidariedade, a fuga de capitais..., tudo isso enfraquece e até impede a comunhão com Deus e a fraternidade" $" 85$.

Para manter seus privilégios, os setores favorecidos, eram totalmente contra uma mudança de estrutura. $\mathrm{O}$ receio pelas reformas e pela inserção do marxismo representaria não só o fim de seus privilégios, mas também a perda dos "valores" da lei de consumo. Os princípios cristãos tais como: pessoa humana, liberdade, solidariedade eram distorcidos, pois consideravam comunista ou subversivo todo aquele que se esforçava pela conscientização e pela mudança da estrutura vigente ${ }^{86}$.

A imagem comunista era acentuada toda vez que se descobria as raízes

\footnotetext{
${ }^{84}$ MUÑOZ, R., Nueva conciencia de la Iglesia en América Latina, 1974, p. 57.

${ }^{85}$ Puebla, 69

${ }^{86}$ MUÑOZ, R., op.cit, 1974, p. 83-84.
} 
materialistas do capitalismo, contra todos aqueles que apresentavam uma possibilidade de um movimento socialista. Opor-se as mudanças era muitas vezes refutada com violência, assim, as ditaduras militares tinham como pretexto o anticomunismo, terrorismo cultural e lavagem cerebral por meio de torturas ${ }^{87}$.

$\mathrm{Na}$ tentativa de mudanças, o próprio setor dominante era o responsável pelas violências $^{88}$. Toda ação, que se opunha a injustiça, era identificada como uma ideologia comunista a qual deveria ser combatida. Com efeito, evitava-se uma transformação das estruturas e das mentalidades ${ }^{89}$.

Os trabalhadores eram tratados desumanamente por seus patrões, sobrevivendo com salários injustos. As leis trabalhistas não eram cumpridas pelos patrões, e os trabalhadores não tinham direito a estabilidade no trabalho ${ }^{90}$.

$\mathrm{Na}$ Conferência de Puebla observa-se que em muitos países latino-americanos se faltava do respeito e da dignidade do homem, sendo evidente pela falta de uma participação sindical. Em muitos países, a legislação era aplicada de forma arbitrária ou nem sequer era levada em consideração. Nos países onde predominava o regime militar, a organização de operários, camponeses e outros grupos populares era impedida com medidas de repressão. Somente os sindicatos patronais não eram impedidos de se organizar para assegurar seus próprios interesses ${ }^{91}$. Assim, como as organizações sindicais eram impedidas pelos patrões. A solidariedade não fazia parte da ideologia na organização do trabalho, desta forma, entre os operários, era

\footnotetext{
${ }^{87}$ Id. 1974, p. 84; La desaparición de Kennedy, el fracaso de la «Alianza para el progreso», ha inclinado definitivamente a los Estados Unidos a ayudar en planes de «anticomunismo» (que en verdad se dirigen contra una revolución popular) mediando el militarismo neocolonial en América Latina. DUSSEL, E., Historia de la Iglesia en America Latina, 1992, p. 212.

${ }^{88} \mathrm{O}$ estabelecimento da paz no mundo é um dos objetivos do cristianismo. Ao lutar pela paz, o cristianismo combate todo tipo de violência, sobretudo a que mata os pobres prematuramente. Esta reflexão abarca também a violência proveniente dos movimentos revolucionários, contrários aos sistemas totalitários presentes no mundo dos pobres. GONÇALVES, P. S. L., Liberationis Mysterium. O projeto sistemático da teologia da libertação. Um estudo teológico na perspectiva da regula fidei, 1997, p. 313, Tesi Gregoriana, Serie Teologia.

${ }^{89}$ MUÑ̃Z, R., op.cit. 1974 , p. 85

${ }^{90}$ Ibid, 1974 p. 86

${ }^{91}$ Puebla, 44
} 
estimulado o espírito competitivo ${ }^{92}$.

As leis sindicais eram muitas vezes usadas como instrumentos de dominação por partidos políticos e oligarquias, sendo também reduzidas as possibilidades de organização operária. Se não bastasse a dominação da classe operária, as autoridades tinham o costume de reprimir violentamente todo protesto. Assim,

As autoridades reprimiam violentamente todo o protesto. Um clima de ameaça e de medo, mediante a repressão policial, prisões, além de torturas e assassinatos. As lideranças dos trabalhadores que procuravam organizar sua classe eram demitidas das empresas e incluídas nas "listas negras", que fechavam as portas para novos empregos. Também líderes estudantis, sacerdotes e religiosos que se esforçavam no trabalho de conscientização do povo, eram perseguidos e presos. As ditaduras militares, em especial, perseguiam aos políticos, aos intelectuais, aos dirigentes populares, aos sacerdotes e religiosos, etc., que denunciavam os abusos sociais e que se colocavam a serviço da promoção dos pobres ${ }^{93}$.

\subsection{2 - A injustiça como fator de violência}

No tocante a vida das maiorias, vemos que esta civilização da riqueza ou do capital, visa não oferecer recursos universais, o que fere os princípios da ética. Atualmente, a civilização está fundamentalmente baseada no individualismo e no bem-viver egoísta, que leva a desumanização. Esse espírito de prepotência desumaniza e gera desprezo, servilismo e reações violentas em outros. A classe dominante, tendo o controle social, econômico e político não permitia à participação e a interação de outros grupos na sociedade, contribuindo assim, para uma desigualdade social

Diante da situação de injustiça e da violência na sociedade, da resistência contra toda e qualquer forma de mudança, gerou uma violência repressiva. Produzia-se um circulo de violência, opressão, subversão e repressão por regimes políticos, que eram contra uma tentativa de mudança, e por uma sociedade que desejava condições

\footnotetext{
${ }^{92}$ Ibid., 1974, p. 86

${ }^{93}$ Ibid., 1974, p. 86-87
} 
melhores de vida ${ }^{94}$.

Mas, qual seria a raiz de toda esta situação degradante na sociedade? Tal agravante estava vinculado a atitudes egoístas, a falta de amor, de fraternidade e solidariedade ${ }^{95}$. A prioridade era o acumulo de bens, e a propriedade privada. Havia um interesse maior pela absolutização do dinheiro, prestígio e poder político. Os ideais de Jesus tais como: dignidade, caridade e solidariedade, eram rebatidos. Desta forma, o sistema capitalista se apresentava de modo em não corresponder ao conteúdo do cristianismo. A benção divina não poderia se estender a uma estrutura social que se opunha a dignidade da pessoa humana, em que os objetivos principais estavam centrados no dinheiro e nos bens materiais, em vista de uma minoria privilegiada. $\mathrm{O}$ princípio ético cristão afirma que aqueles que mais têm podem contribuir com aqueles que menos têm ${ }^{96}$.

Dos bens de consumo podemos ter uma certeza, contribui para uma desigualdade social e a dificuldade na geração da solidariedade. O empenho a solidariedade na sociedade latino-americana tem sido um grande desafio, devido há muitos fatores que impedem a justiça e melhores condições de vida. A falta de solidariedade se manifesta em muitos mecanismos geradores de pobreza, miséria e exclusão. As causas imediatas desta situação são as injustiças nas relações econômicas internacionais, na expansão das multinacionais, na globalização ${ }^{97}$ do livre mercado neoliberal, na imensa e impagável dívida externa, na injusta distribuição das riquezas entre o Norte, o Centro e o Sul do Continente americano, no narcotráfico e na falta de respeito aos direitos humanos, sobretudo em relação aos mais pobres e às

\footnotetext{
${ }^{94}$ MUÑOZ, R., Nueva conciencia de la Iglesia en América Latina, Salamanca: Ediciones Sígueme, 1974, p. 86-87; Puebla, 328, 355, 509

${ }^{95}$ De onde ou em quem está concretamente vinculado dentro da sociedade o este pecado? A localização do pecado segue a mesma direção de seu juízo ético: se reconhece o pecado cristalizado nas próprias estruturas da sociedade, na ordem em que configura esta situação de pecado; o pecado é visto também nos homens e mais concretamente nas minorias favorecidas enquanto estas usufruem da situação de exploração dos mais pobres e sobretudo quando a mantem voluntariamente pela violência. Nestas minorias, ao menos consideradas coletivamente, é onde se ve particularmente ativo esse egoísmo que se reconhece como a raiz da situação de pecado. MUÑOZ, R. Op.cit., 1974, p. 101

${ }^{96}$ MUÑOZ, R., Nueva conciencia de la Iglesia en América Latina, 1974, p. 94

${ }^{97}$ AGUER, H. R., El fenómeno de la globalización, in: Iglesia in América, Al encuentro de Jesucristo vivo, 2001, p. 271-272
} 
minorias étnicas (mestiços, indígenas e afroamericanos) ${ }^{98}$. São João Paulo II acentua como fonte destes problemas as atitudes morais, ele afirma que entre as atitudes que contribuem para o desequilíbrio econômico está à ganância e a sede de poder. Tais atitudes dão origem a outras omissões, que acabam criando estruturas de pecado, que podem ser verificadas nos "poucos que têm muito e nos muitos que têm pouco" 99 .

Não se pode negar que a luta dos cristãos latino-americanos contra a falta de solidariedade estará, portanto, enraizado no campo da ética e no combate à ganância dos poderosos, na área social. É necessário um empenho e uma conscientização da sociedade, em contribuição para uma ordem mais justa das relações políticoeconômicas.

Em nossa sociedade é visível que as injustiças sociais são de ordem moral. Desta forma, é certo falar de uma solidariedade que possa reagir às injustas condições de vida sofridas pelos mais pobres. "Diante de tantos desafios e barreiras para superar os grandes problemas, é necessário começar fazendo simplesmente o que é possível"100. A solidariedade, nada mais é, do que colocar-se no lugar dos pobres e com eles buscar alternativas e meios para que possam superar os problemas que os afligem.

\footnotetext{
${ }^{98}$ GONÇALVES, P. S. L., Liberationis Mysterium. O projeto sistemático da teologia da libertação. Um estudo teológico na perspectiva da regula fidei, 1997, p. 314, Tesi Gregoriana, Serie Teologia.

${ }^{99}$ João Paulo II, Sollicitudo Rei Socialis , n. 41. 145; Ibid, n. 37. João XXIII, Mater et Magistra, n. 238. 146

${ }^{100}$ João XXIII, Mater et Magistra, n. 238. 146
} 


\section{3 - Consequencias sociais}

Em nossa sociedade não é muito difícil perceber aqueles que se encontram a margem, desprovidos de uma boa qualidade de vida, de uma estrutura em que possa dar o suficiente para uma vida digna e de respeito. A falta de um comprometimento com a sociedade, faz com que muitos se tornem inferiores a uma minoria bem superior, por não haverem recursos para uma vida sustentável ${ }^{101}$.

Segundo Puebla, a pobreza afeta numerosos setores da América Latina que tem na vida real expressões bem concretas, das quais se podem reconhecer as feições sofredoras de Cristo, tais como: crianças golpeadas pela pobreza já bem antes de nascerem $(32,318,573,577,612,1261)$; crianças abandonas e exploradas em resultado da pobreza e desorganização familiar (32); jovens desorientados por não encontrarem um lugar na sociedade (33); jovens frustrados pela falta de oportunidade de trabalho $(33,1176)$; indígenas que vivem segregados em condições desumanas (34); os afro-americanos considerados escravos $(34,365)$; os camponeses que vivem sem terra e explorados (36); operários frequentemente mal remunerados (36); os desempregados e subempregados (37); os marginalizados que sofrem pela falta de bens materiais (38); mulheres oprimidas e marginalizadas (1153) e também os anciãos que estão a margem da sociedade por serem considerados inválidos à produção (39). Puebla amplia muito mais o leque dos pobres, quando demonstras preocupação pelas angustias daqueles que se encontram em solidão, por aqueles que estão com problemas familiares, por aqueles que sofreram abusos de poder, repressão, torturas, violência de guerrilhas, terrorismo e sequestros (40-43). Com efeito, Puebla tentar de uma forma geral, ao longo de todo o documento (na nota 2 ao n. 1135), definir que a expressão "pobre" ou "pobreza" refere-se a uma carência tanto de bens materiais, quanto de participação social e política.

Em vista da situação destes menos favorecidos, vale recordar o apelo que Paulo VI fez no discurso de abertura da conferencia Geral de Medellín:

${ }^{101}$ Centesimus Annus, 48 
Se devemos favorecer todo esforço honesto visando promover a renovação e elevação dos pobres e de todos os que vivem em condições de inferioridade humana e social, se não podemos solidarizar-nos com sistemas e estruturas que encobrem e favorecem graves e opressoras desigualdades entre as classes e os cidadãos de um mesmo país sem realizar um plano efetivo para remediar as insuportáveis condições de inferioridade que muitas vezes sofre a população menos favorecida. Nós mesmo repetimos mais uma vez a este respeito: nem o ódio nem a violência, são a força de nossa caridade.

A expressão do Papa nos faz perceber a importância dos testemunhos sociais na sociedade. Mas também exorta em dar continuidade a tais testemunhos para que estes tenham uma maior eficácia. Neste sentido o serviço social deve ser prestado da melhor maneira possível, para assim ter maior expansão e encarnar-se cada vez mais na vida do Povo de Deus. Manifesta que, não podemos fazer renovação à luz do Concílio e conduzir uma promoção dos pobres e de todos que vivem em condição de inferioridade humana e social pela força do ódio e da violência, pois o verdadeiro cristianismo implica sempre amor, justiça e paz ${ }^{102}$.

Na América Latina é urgente a libertação de pessoas que vivem em extrema pobreza. Como também é visível a grande desproporção de salários, sérios problemas de moradia, má distribuição de bens como alimentação e vestuário, refletindo a deficiência em nossa sociedade na ordem econômica. Podemos citar também a desestrutura na saúde e a falta de incentivo à educação, bem como o stress do dia-dia devido à impossibilidade de descanso e de lazer. Tudo isso faz com que nossa sociedade se apresente de uma forma deteriorada e doente ${ }^{103}$.

No documento de Puebla denuncia:

Comprovamos, pois, como o mais devastador e humilhante flagelo a situação de pobreza desumana em que vivem milhões de latino-americanos e que se exprime por exemplo, em mortalidade infantil, em falta de moradia adequada, em problemas de saúde, salários de fome, desemprego, subemprego, desnutrição, instabilidade no trabalho, migrações maciças, forçadas e sem proteção ${ }^{104}$.

Puebla nos faz redescobrir e reassumir esta dimensão de evangelização: libertação de miséria. Diante da constatação de que uma grande maioria continua a

102 BARBOSA, F. DE B., A cristologia de serviço e seguimento no debate eclesial e teológico latinoamericano, Tese doutoral, 1998, p. 156.

${ }^{103}$ Medellín, Família, 3.3

${ }^{104}$ Puebla 29 
viver numa situação de pobreza e de miséria ${ }^{105}$, o compromisso eclesial deve ser como o de Cristo: um compromisso com os mais necessitados ${ }^{106}$.

Diversas camadas da sociedade se sentem abandonadas por uma falta de estrutura competente capaz de dar apoio e condições melhores de vida. Os problemas decorrentes do fenômeno acima são a miséria e a ignorância, que impedem muitas vezes que a sociedade se desenvolva e gere condições apropriadas de vida.

Puebla, embora focalize principalmente a angustia que nasce da pobreza e da miséria, percebe diversas causas que angustiam os membros do povo da América Latina. "Preocupam-nos as angustias de todos os membros do povo, qualquer que seja sua condição social: sua solidão, seus problemas familiares, a falta de sentido que não poucos vêem na vida ${ }^{107}$. . Na sociedade, a grande maioria oprimida e explorada se torna a classe mais baixa, e consequentemente, distinta de uma minoria. Isso faz com que acentue o nível de inferioridade da grande parte da população. Esta inferioridade e angústia são refletidos em alguns setores da população, entre elas a família, pois, uma falta de estrutura social é desafiadora e que pode comprometer até mesmo a estrutura familiar $^{108}$.

${ }^{105}$ Puebla, 1135

${ }^{106}$ Puebla, 1141

${ }^{107}$ Puebla, 27

${ }^{108}$ Centesimus Annus, 39 
Nas famílias constituídas, as desumanas condições de vida e de trabalho permitem apenas a comunicação entre os esposos e a socialização e personalização dos filhos. Não podemos esquecer a condição servil em que a mulher se encontra, mesmo com a atual projeção da mulher no mercado de trabalho, muitas são exploradas sexualmente e domesticamente pelo homem ${ }^{109}$. Ou mesmo quando a mulher se vê obrigada a assumir responsabilidades, no momento em que o marido abandona o lar, dificultando mais ainda a convivência e a sobrevivência dos filhos. Desta forma, o fenômeno da mulher como chefe de família cresce e se constitui na sociedade.

A desintegração da família na América Latina também está associada à introdução do divórcio na sociedade, o abandono do lar, muitas vezes por parte do pai, e a desproporção de salários entre o homem e a mulher que dificulta as condições reais de uma família.

Em vista da atual situação da sociedade e até mesmo da família, torna-se necessário, a partir da lei do amor conjugal, promover uma reconciliação que poderá conduzir a comunhão e a participação, e não a dominação.

Não é de se admirar que a desestrutura social na sociedade começa a se apresentar em expressões de ansiedade, preocupações, inseguranças, angústias e medos. A tensão maior estava na condição em que quando se tinha mais medo mais se perdia a liberdade. O medo reprimia uma ação, uma manifestação, um senso

${ }^{109}$ A libertação dos pobres também necessita ser efetivada a nível de sexualidade. Assim, ultrapassa-se o plano pessoal e personalista que marcou a história da sexualidade, abarca a política e se realiza uma libertação global. Na sociedade classista predomina a ideologia de manutenção do status quo que comercializa o sexo, controla a natalidade por meio da distribuição indiscriminada de qualquer tipo de anticonceptivos e de esterilização em massa e da prática do aborto, traz à tona a liberação sexual virgindade é tabu e matrimônio é coisa do passado - sem nenhum critério axiológico consistente. Torna-se necessário assumir alguns desafios morais e pastorais viáveis para defrontar-se com o problema da sexualidade. O primeiro é descobrir a ambivalência da sexualidade sem limitar-se ao plano pessoal, mas estemdê-la a nível da dinamicidade da sociedade no seu todo. O segudo é balizar as normas morais nos valores evangélicos para que se supere a moral individualista e consumista da sociedade mundial na atualidade. O terceiro é reforçar o caminho de uma práxis eclesial articulada com uma práxis social transformadora. A Igreja desenvolve a sua missão no mundo e a sexualidade é desafio social global. Este modo de dirigir-se à sexualidade visa a humanização plena de todo ser humano para a dignidade de filhos e filhas de Deus. GONÇALVES, P. S. L., Liberationis Mysterium. O projeto sistemático da teologia da libertação. Um estudo teológico na perspectiva da regula fidei, 1997, p. 324-325, Tesi Gregoriana, Serie Teologia. 
crítico, uma possibilidade de consciência da situação atual da sociedade. $\mathrm{O}$ medo também era a capacidade de uma entrega a toda uma iniciativa ao poder de um Estado paternalista $^{110}$.

$\mathrm{Na}$ Gaudium et Spes também expressou preocupação pela sociedade explorada e oprimida: "Muitos dos nossos contemporâneos... inquietos, se interrogam, num misto de esperança e angustia, sobre a evolução atual do mundo ${ }^{111}$ ". Que sentido passa a ter a vida? Qual caminho a tomar? A angústia fazia com que a sociedade se sentisse mais presa de forma a almejar mais espaço, liberdade, possibilidades.

Do mal da miséria e da angustia que aflige, algo mais ameaçador e destruidor se faz também presente: a injustiça, a iniquidade. O homem é um ser livre e com esta liberdade ele se realiza. A maneira mais positiva no uso desta liberdade é na forma como o homem se relaciona com o outro na possibilidade de amar, irradiar o bem e o respeito. No entanto, a recusa em promover o amor e o respeito, faz com que o homem se feche no seu egoísmo e promova a injustiça e a iniquidade. Eis o mal moral que destrói, prejudica e corrompe a dignidade humana ${ }^{112}$.

Observa-se a tendência de cada um em defender a si mesmo e a seu núcleo familiar. Isso afeta o aspecto cultural, visto que muitas vezes provoca uma espécie de 'salve-se quem puder', ou 'eu me viro como posso'. Vendo as coisas desse modo pode-se afirmar que existe um novo tipo de individualismo que afeta todas as camadas sociais, não só a antiga classe média ou a classe alta, mas também a antiga classe trabalhadora, cada vez menor (isto é, com menos trabalho industrial) e mais desorganizada. Muitos pobres refugiam-se na economia informal (trabalhando por conta própria, como mensageiros ou vendedores ambulantes $)^{113}$.

Esta injustiça é um comportamento maléfico, que se impõe, quer dominar, construir uma realidade ou até mesmo um "reino" que se opõe ao Reino de Deus. Aquilo que corresponde ao "bem" gera o respeito, dignidade, por outro lado o "mal" refere-se ao egoísmo, a recusa do amor. O próprio Jesus nos fala do "fermento do mal" e nos ensina vigilância: "cuidado, acautelai-vos do fermento dos fariseus e dos

\footnotetext{
110 TEPE, V., Estamos Salvos, 1982, p. 18-19

${ }^{111}$ Gaudium et Spes 4

112 TEPE, V., op.cit., 1982, p. 19-20

113 SCANNONE, J. C., O comunitarismo como alternativa viável, in: O futuro da reflexão teológica na América Latina, 1998, p. 152.
} 
saduceus" (Mt 16,6) ${ }^{114}$.

Em suma, pode-se dizer que os problemas socioeconômicos e político-culturais da América Latina afetaram profundamente a sociedade latino-americana, impedindo sua plena realização. Se a sociedade se desestrutura, a educação familiar também se fragmenta. O sentimento de inferioridade em decorrência da pobreza, miséria e abandono das estruturas sócio-políticas, nada mais é do que um reflexo de um sistema agressivo e desumano em que os valores de vida são postos de lado.

Do ponto de vista social experimenta-se uma degradação das condições de vida dos economicamente desfavorecidos, como o aumento do desemprego, uma maior assimetria na distribuição de rendas e um Estado menos previdente. Ao mesmo tempo faz-se presente uma abundância na oferta de produtos de larga escala, instaurando-se hábitos de consumo que beiram ao desperdício, ao lado de situações de miséria que formam por vezes um quarto mundo dentro do primeiro. A cultura moderna, seja em sua vertente capitalista, seja em sua vertente socialista, parece perder sentido e plausabilidade para muitos, colocando-se a necessidade da emergência de novas formas culturais compatíveis com o novo aumento do capitalismo. Coloca-se neste contexto o surgimento de novas condições existenciais e de uma nova cultura que chamamos de pós-modernidade ${ }^{115}$.

Atitudes como egoísmo, orgulho, ambição e inveja foram capazes de gerar injustiça, dominação e violência. O próprio Documento de Puebla confirma as dificuldades existentes na sociedade latino-americana e juntamente a necessidade de uma ação evangelizadora para com os mais oprimidos e marginalizados.

A realização histórica desse serviço evangelizador será sempre árdua e dramática, porque o pecado, força de ruptura, há de impedir constantemente o crescimento no amor e a comunhão tanto a partir do coração dos homens, como a partir das diversas estruturas por eles criadas, nas quais o pecado de seus autores imprimiu sua marca destruidora. Neste sentido, a situação de miséria, marginalidade, injustiça e corrupção que fere nosso Continente, exige do Povo de Deus e de cada cristão um autêntico heroísmo em seu compromisso evangelizador, a fim de poder superar semelhantes obstáculos. Diante de tal desafio, a Igreja sabe que é limitada e pequena, mas se sente animada pelo Espírito e protegida por Maria. Sua poderosa intercessão lhe permitirá superar as "estruturas do pecado" na vida pessoal e social e lhe obterá a "verdadeira libertação", que vem de Cristo Jesus ${ }^{116}$.

114 TEPE, V., Estamos Salvos, 1982, p. 26

115 ANDRADE, P. F. C. de. A condição pós-moderna como desafio à pastoral popular. In: REB Revista Eclesiástica Brasileira, v. 53, n. 209 , p. 99-113, 1993.

${ }^{116}$ Puebla, 281 


\subsection{1 - A pobreza e a educação na sociedade latino-americana}

Um dos grandes problemas enfrentados na sociedade latino-americana é a falta de uma estrutura educacional consistente. A condição de pobreza e miséria na sociedade está devidamente relacionada com os processos educativos ${ }^{117}$. A taxa de analfabetismo e a deserção escolar se encontram nos setores mais pobres da sociedade, tais circunstancias fazem com que a possibilidade em conseguir emprego se torne difícil. O sistema educativo se torna insuficiente e incapaz de atender a sociedade para dar aos jovens capacidades e recursos para conseguir um bom emprego $^{118}$. A educação na América Latina sofreu também outros problemas: a incapacidade educativa e social não foi suficiente para suprir as demandas no ingresso às universidades. Consequentemente, estes jovens frustrados não conseguem nem capacitação e muito menos a possibilidade em conseguir um emprego ${ }^{119}$.

O Documento de Medellín já nos apresenta dados referentes à educação na América Latina. O analfabetismo e a deserção escolar tinham uma elevada porcentagem em toda a sociedade latino-americana. Faltavam escolas adequadas e até mesmo professores qualificados para uma formação educacional consistente. Os setores da população mais carente estavam desprovidos de acesso à cultura. A população de modo geral não tinha condição de firmar-se como um povo em que era sujeito de sua própria história e destino. A formação educacional era transmitida de forma alienante de maneira que o ensino (médio e superior) não correspondia à realidade social. Uma cultura acadêmica imposta, formalista e abstrata, esta era a realidade do ensino na América Latina. Tal formação não incorporava uma dimensão criativa e inovadora nos jovens, pois, não desenvolvia uma mentalidade crítica e questionadora. A finalidade da formação educacional era integrar o educando num

\footnotetext{
117 Pero el sentido más hondo de estas expressiones es insistir em la necesidad para los pueblos oprimidos de América Latina de tomar las riendas de su propio destino; Medellin propugna por eso uma 'educación liberadora' que, citando a la Populorum Progressio, es vista como el medio clave para liberar a los pueblos de toda servidumbre y para hacerlos ascender 'de condiciones de vida menos humanas a condiciones más humanas', teniendo en cuenta que el hombre es el responsable y el 'artífice principal de su éxito o de su fracaso'. GUTIÉRREZ, G., Teologia de la liberación, 1975, p. 153.

${ }_{118}$ Puebla, 1014

${ }^{119}$ Puebla, 1051
} 
sistema como elemento de produção, ou seja, a educação não passava de uma simples alfabetização $^{120}$.

Na Conferência de Medellin já se encontra críticas ao método de formação educacional em que estão preocupados somente na transmissão de conhecimentos e não numa capacidade crítica e questionamentos. Já desde a década de 60 o sistema educacional estava mais interessado numa manutenção de estruturas sociais e econômicas, do que uma transformação educacional ${ }^{121}$. Era vigente na América Latina, quando já se apresentava uma riqueza do pluralismo cultural, uma mentalidade mais individualista e competitiva gerada por uma educação uniforme e $\operatorname{passiva}^{122}$.

Os preconceitos, inibições, fanatismos, complexos de inferioridade, tendências fatalistas, desconfiança e passividade em relação às possibilidades de mudança, deveriam ser libertados daqueles que são analfabetos, marginalizados e escravos da ignorância ${ }^{123}$.

Evidentemente que ao se falar de uma educação religiosa os resultados não eram satisfatórios. Muitos questionamentos surgiram, com relação às instituições católicas. Primeiro, por favorecer o elitismo e a mentalidade classista, como também por escassos resultados na educação da fé e pelas mudanças sociais. Em vista disso, muitos religiosos optaram por abandonar o campo da educação e inserir-se diretamente em outra área em que pudessem contribuir pastoralmente ${ }^{124}$.

De qualquer forma, mesmo tendo escolas em que exerceram suas atividades educativas, estas tiveram a manipulação e instrumentalização de certas classes elitistas que atuaram conforme seus interesses ou projetos político-econômicos.

Àqueles que estão à margem da sociedade esperam uma atitude, uma ação que os faça ter mais dignidade humana. No entanto, a degradação social começa a ter seus

\footnotetext{
${ }^{120}$ Medellín, Educação, 4.4

${ }^{121}$ Medellín, Educação, 4.4

${ }^{122}$ Medellín, Educação, 4.4

${ }^{123}$ Medellín, Educação, 4.3

124 Puebla, 1019
} 
efeitos em alguns setores da sociedade. É o sentimento de inferioridade que se compreende, não somente na família e na educação, mas, em muitos outros setores da sociedade, onde somos capazes de perceber a opressão e exploração de uma pessoa. Não se pode negar que a fragilidade destes dois setores, que nos faz perceber um “efeito dominó", no que diz respeito a desestrutura social. Se a família se deteriora e a educação se torna ineficaz é porque o sistema já se torna operante. Um sistema que não se interessa necessariamente pelos valores humanos manifestados no seio familiar, ou até mesmo, pelo respeito que se possa ter a alguém. Privados por um sistema que escraviza a sociedade se torna incapaz de agir na busca de melhores condições de vida.

\subsection{2 - Os desafios de uma invisibilidade social}

De princípio, no que diz respeito à invisibilidade social, é necessário acentuar uma relação entre indivíduos e apresentar a importância da identidade social. Mas

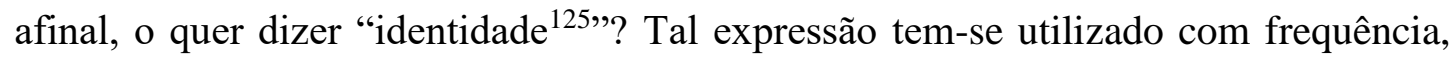
porém, ainda parece carecer de uma definição em que se tenha um rigor científico. De qualquer forma, não podemos estabelecer um relato fiel com uma pessoa sem acentuarmos um nível de relacionamento de um para com outro. Assim, a identidade é definida pela relação do indivíduo com aqueles que estão a sua volta, em seu convívio social. É com a relação entre o eu e o outro que se edifica a identidade do $\mathrm{eu}^{126}$.

${ }^{125}$ Mientras la historia del tercer milenio nace al ritmo de la globalización mundial, el hombre contemporáneo busca, cada vez mayor fuerza, definir su propia identidad para no caer en la desorientación. SANDRI, L., La identidad Cristiana de América, in: Iglesia in América, Al encuentro de Jesucristo vivo, 2001, p. 183.

${ }^{126}$ A Identidade do eu não se refere ao ser individual e absoluto, mas a uma identidade que se processa pela apropriação/negação/superação dos universos simbólicos na interação social. A formação da identidade ultrapassa a biografia pessoal, à medida que o sujeito busca sua singularidade compreendendo sua ação estratégica e comunicacional no espaço em que atua. Essa percepção [...] se refere ao processo de identidade como 'experiencia de saber que eu sou eu na relação com os outros, e mais, de saber que não sou tudo o que sou pela minha relação com o não-eu-identidade. Assim, a identidade nunca está instalada e acabada. $O$ sujeito se reconhece na relação como outro, mas a experiência do outro não é totalmente vivida pelo sujeito. O conhecimento entre eu e o outro é 
A identidade refere-se a um reconhecimento de todos os elementos constituintes de uma pessoa tais como: sentimentos, desejos, necessidades, valores, virtudes e etc $^{127}$. O não reconhecimento de tais elementos pode comprometer o princípio de identidade, assim, a invisibilidade social começa a dar seus primeiros passos.

Podemos constatar tal atitude de invisibilidade social quando nos deparamos com determinadas funções públicas em nossa sociedade. O lixeiro ou o gari que uniformizados executam suas funções, muitas vezes são vistos de acordo com aquilo que representam: um servidor público. É evidente que a invisibilidade social pode se estender para tantas outras estruturas em nossa sociedade, como um deficiente físico, um analfabeto, um mendigo, ou também, para aquilo que muitas vezes pode ser considerado como uma postura ingênua, em permanecer muito tempo entretido num tablet ou celular, pode acarretar numa postura de invisibilidade social. Nesta última, com a interação virtual, rompe com a capacidade em estabelecer um vínculo ou uma afinidade com o círculo social ao redor. O individuo não é um ser isolado do contexto social em que se encontra. Para a relação entre os indivíduos requer uma estrutura em que se promova a interação e que influencie a efetivação da identidade ${ }^{128}$.

Assim sendo, a invisibilidade social é o sintoma de uma crise de identidade nas relações entre os indivíduos da sociedade contemporânea, tendo como causa principal, os efeitos da estrutura socioeconômica proveniente do sistema capitalista e da cultura do consumo ${ }^{129}$. Desta forma, podemos nos perguntar se de fato o aspecto socioeconômico se torna um dos fatores determinantes para a invisibilidade humana, por estabelecer um distanciamento ou a supressão de uma relação social.

mediado por uma comunicação na qual eu informa a respeito do outro e recebe a informação sobre a identidade que o outro lhe atribui. BORBA, A. M. DE, Identidade em construção. 2001, p. 34.

${ }^{127}$ A identidade vai se constituindo no movimento do 'estar sendo', movimento este de progressão e regressão de valores e significados, sejam eles conscientes ou não. Ibid, 2001, p. 35.

${ }^{128}$ A identidade é apresentada em um ambiente em que ao mesmo tempo 'mundos subjetivos' vividos pelos sujeitos na sua trajetória social e 'mundos expressos', objetivos e suscetíveis de serem apreendidos empiricamente. Assim, a identidade se dá na interação social, situando as pessoas e as interações. Ibid, 2001, p. 35

${ }^{129}$ A própria evolução do mercado é um elemento estrutural que impede negociações com este perfil profissional. Assim, o mecanismo de articulação da identidade está fraturada. Há sintomas de perda nas interações sociais e os sujeitos sofrem uma brutal desintegração nas transações subjetivas, gerando uma desvalorização. BORBA, A. M. DE, Identidade em construção. 2001, p. 41. 
A cultura do consumo faz com que grupos se tornem distintos um de outros. Tal circunstância, nos leva a crer que por base ao sistema capitalista aquele grupo de pessoas que tem um poder aquisitivo maior se torne o grupo mais expressivo e mais visível da sociedade. Os marketings de muitas empresas, fornecedoras de bens de consumo, já definem suas propagandas para grupos distintos de pessoas pertencentes a seu aspecto sociocultural. Tem-se como objetivo, das campanhas publicitárias, aproximarem os respectivos grupos consumidores já distintos na sociedade com aquele produto específico a ser vendido. Neste aspecto temos dificuldades em promover relações sociais, pois a sociedade é considerada como consumidora em potencial, ou seja, se somos consumidores, nossa identidade estaria moldada por meras questões mercadológicas ${ }^{130}$.

Ao seguir o princípio do ideal do consumo, nós nos tornamos todos invisíveis até que revelemos nossa identidade, nosso vinculo de relação humana ${ }^{131}$.No que diz respeito à invisibilidade social, no âmbito dos mais marginalizados e oprimidos, podemos perceber que eles são as principais vítimas da invisibilidade. E isso acontece ao fato de não terem recursos suficientes para se identificarem a um grupo de poder aquisitivo maior. Não podemos deixar de ressaltar que estes marginalizados e oprimidos se encontram a margem da sociedade, necessitam de recursos e ferramentas básicas, suficientes para que possam ter uma vida digna e de respeito. Mas que muitas vezes, pela estrutura vigente na sociedade, por motivos políticos e socioeconômicos não lhe são capazes de fornecer uma assistência adequada para uma vida satisfatória.

A invisibilidade social atinge cada vez mais a maior parte da população de baixa

\footnotetext{
${ }^{130}$ No quadro da Invisibilidade pública a comunicação entre os humanos fica prejudicada, regride, tendendo a formas de troca demasiado econômicas. Estabelece-se entre os sujeitos um tipo de conversa que não é conversa, mas regime daquilo que, em geral consagra o que é primordial numa economia capitalista: troca de mercadorias e serviços. Os assuntos emagrecem e, anoréxicos, arrastam-se em direção ao que parece essencial: quanto custa, quando entrega, como se paga, que garantia é oferecida. Mesmo pessoas envolvidas em atividades profissionais não atreladas diretamente à venda e compra de objetos, vêem-se constante e mais ou menos conscientemente ocupadas em adequar-se a tal rotina. DA COSTA, F. B., Moisés e Nilce: retratos biográficos de dois garis. Um estudo de psicologia social a partir da observação participante e entrevistas. Tese doutoral, 2008, p. 17.

${ }^{131}$ A invisibilidade pública só pode encontrar remédio na amizade. A afeição, a simpatia, o apreço pelo amigo é o que nos resgata da vala comum. Um companheiro que nos se apega eleva nossa dignidade, restaura nossa humanidade corroída pelas consequências da reificação. Ibid, 2008, p.228.
} 
renda, como também aquelas pessoas que se encontram com pouco grau de escolaridade. Tal situação acontece por serem profissionais considerados de pouca significância. Eis o nosso engano. Os trabalhadores que sofrem muitas vezes tal preconceito são aqueles que também prestam serviços importantes para a sociedade. Muitos são responsáveis pelos serviços de base, mesmo sendo considerados como mão de obra barata e com salários prejudicados, eles possuem um papel importante, porém com pouca valorização.

A invisibilidade social se dá, quando na maioria das vezes, não exercem serviços de significativa aparição pública ${ }^{132}$. Muitos estão ali trabalhando ou apenas vivendo, independente da ocupação, muitas pessoas passam por eles e não os enxergam. Tais indivíduos invisíveis podem ser vendedores ambulantes, porteiros, motoristas de ônibus, bilheteiros, faxineiros, entre outros ${ }^{133}$.

\footnotetext{
${ }^{132}$ No ambiente de trabalho, o empenho braçal costumava ser a exigência única. A severidade com que isso ocorria, em frequência repetitiva e caráter autoritário, fabricava e promovia, incessantemente, relações desniveladas. Os homens ai envolvidos não apareciam por suas capacidades. De modo distorcido, apresentavam-se como representantes de cargos determinados. Desse modo, não apareciam as pessoas, mas sim suas funções. DA COSTA, F. B., Moisés e Nilce: retratos biográficos de dois garis. Um estudo de psicologia social a partir da observação participante e entrevistas. Tese doutoral, 2008, p. 228

${ }^{133} \mathrm{~A}$ invisibilidade pública, desaparecimento do homem em meio aos outros homens, é expressão pontiaguda de dois fenômenos psicossociais que assumem o caráter crônico nas sociedades capitalistas: humilhação social e reificação. A invisibilidade pública é resultado de um processo histórico de longa duração. Rebaixa a percepção de outrem, especialmente a percepção de alguém vinculado à forma baixa de trabalho assalariado, o trabalho desqualificado, alienado e alienante. DA COSTA, FERNANDO BRAGA, Moisés e Nilce: retratos biográficos de dois garis. Um estudo de psicologia social a partir da observação participante e entrevistas. Tese doutoral pela Universidade de São Paulo, Departamento de psicologia social e do trabalho, São Paulo, 2008, p. 16
} 
Mas a pergunta é, por que não conseguimos vê-los? Supõe-se que a cegueira que afeta a sociedade pode ser encarada como um fenômeno político. Isso pode estar associado a um fenômeno político, pois pode estar relacionado com a desigualdade entre as classes sociais. Com efeito, o fato de não perceber o outro pode estar vinculado a um preconceito devido à distinção de classes sociais, como também pode estar associado a uma falta de comunicação ou até mesmo pelo medo da violência ${ }^{134}$.

A invisibilidade social sendo caracterizada por uma cegueira decorrente das diferenças de classes sociais faz com que a recusa em ver os outros, pode se referir a não correspondência de seus desejos e intenções. Assim sendo, encontramos a invisibilidade social vinculada também a fatores econômicos, raciais, sexuais de faixa etária e entre outras.

A luta contra a invisibilidade social é um desafio. Atitudes como humilhação e desprezo podem fazer com que as vítimas de tais ações se tornem muitas vezes depressivas.

Fernando Braga da Costa em sua tese doutoral ${ }^{135}$, afirma que é constituinte de todo o trabalhador ter alguma valorização e que isto é parte integrante da vida ${ }^{136}$. Seria importante para o ser humano, ser alguém, ter valor e ser reconhecido por este

134 A estratificação social combina os aspectos econômicos e socioculturais e vincula a situação de classe a uma condução de vida específica. Esta condução de vida representa uma dada atitude em relação ao mundo em todas as dimensões sociais, não se restringindo, portanto somente à subsfera econômica. [...] é desta forma que se permite construir laços objetivos de solidariedade, por um lado, e preconceito do outro. Será também esta condução de vida, ou atitude em relação ao mundo, que propiciará a justificação de privilégios ao permitir que estes apareçam como qualidades inatas dos indivíduos e não como socialmente determinados. Assim, surge uma 'inconsciência de classe', na medida em que a origem social de privilégios é 'naturalizada'. [...] É neste contexto que se permite explicar e também compreender a apatia política e a invisibilidade da dominação social no capitalismo contemporâneo, dado que tanto a solidariedade quanto o preconceito de classe são produzidos e reproduzidos de modo cifrado, inarticulado e 'naturalizado'. SOUZA, J., A invisibilidade da raça e a invisibilidade da classe, in: A invisibilidade da desigualdade brasileira, 2006, p. 73-74.

135 DA COSTA, F. B., Moisés e Nilce: retratos biográficos de dois garis. Um estudo de psicologia social a partir da observação participante e entrevistas. Tese doutoral, São Paulo, 2008, p. 16

${ }^{136}$ Um dia há de se alcançar uma cultura em que não deixará de englobar os valores dos que trabalham, valores que se opõe aos que dominam. Valores como o interesse verdadeiro pelo outro, a maneira direta de falar, o sentido do concreto e a largueza com relação ao futuro, uma confiante adesão à humanidade que virá, tão diferente do projeto burguês para o amanhã, da redução do tempo ao contábil que exprime o predomínio do econômico sobre todas as formas de pensamento. E, quem sabe, a nossa cultura ganhará o que perdeu: o trabalho manual, o cultivo da terra, a ligação religiosa com o Todo. DA COSTA, F. B., Moisés e Nilce: retratos biográficos de dois garis. Um estudo de psicologia social a partir da observação participante e entrevistas. Tese doutoral, 2008, p. 381 
valor. O mesmo acontece com algum papel social relevante na sociedade. E a falta do reconhecimento de seus valores torna a pessoa invisível e as consequências disso conduz a pessoa a uma depressão ou até mesmo ao suicídio.

É evidente que na sociedade onde o sistema é o capitalismo, podemos perceber que este se torna um dos maiores causadores do fenômeno de invisibilidade e de cegueira pública. Com efeito, é fácil identificar dentro das grandes diferenças entre as classes sociais um cenário de discriminação e de humilhação ${ }^{137}$. A questão da invisibilidade social é um processo complexo, que se torna cada vez mais evidente em nossa sociedade, em que pode remeter-se tanto por motivos culturais quanto psicológicos. Assim sendo, uma atitude discriminatória pode ser cometida ou devido à influência do meio em que se vive, ou por base de experiências históricas inseridas numa sociedade. De qualquer forma, é necessário ter acessos aos desafios presentes na sociedade para que se possa promover uma atitude que se oponha a invisibilidade social.

É claro que, com apoio de uma hermenêutica, pode nos ajudar a "abrir os olhos" para invisibilidade social e nos aproximar daqueles que estão a margem da sociedade, ou seja, pessoas que muitas vezes são consideradas excluídas, as mais pobres, as que sofrem tanto por uma doença ou deficiência física ou, de modo geral pelas próprias dificuldades da vida. A importância de um vínculo social se torna necessário para a promoção dos valores humanos e o cultivo da dignidade humana. Somente com o reconhecimento destes valores e até mesmo das virtudes, que constituem cada pessoa, podemos nos identificar como pessoas que se respeitam e que buscam pelos seus direitos por uma sociedade mais digna.

${ }^{137}$ A invisibilidade pública forma-se entre 'cegos superiores' e 'subalternos invisíveis'. No cego representa obliteração na comunicação com cidadãos rebaixados, representa interdição de nossa sensibilidade à revelação de outrem como revelação de alguém. Insensatez, ignorância e indelicadeza. O sujeito cegado comporta-se com ignorada impolidez ou com indiferente impolidez; passa neutro pelos pobres, como quem passa por objetos, por obstáculos, ou o faz presunçosamente e sem perturbação. [...] O sujeito cegado opõe-se a uma experiência de igualdade e de alteridade que, sem oposição, alcança-nos naturalmente e irresistivelmente. Forja não ter consciência do outro, assume conduta insana, age com doidice; contesta, apaga, recusa um registro: não reconhece a existência de outrem. Ibid, 2008, p. 376. 


\section{4 - A situação religiosa}

É necessário agora verificar qual foi o papel da Igreja Católica na América Latina que fez com que esta região se tornasse expressivamente católica ${ }^{138}$. Desde o período da descoberta a Igreja estava sempre presente no processo de colonização ${ }^{139}$. Assim sendo, a opressão e exploração das maiorias se davam num continente cristão e a Igreja se tornava mais solidária aos povos com quem conviveu já desde o processo de colonização, tendo em vista todo o seu passado, valores e organização social $^{140}$.

Os problemas internos dentro da Igreja começam a surgir porque nela se encontram pessoas de diferentes classes sociais. Tais problemas eram evidentes devido às relações econômicas, políticas e ideológicas da própria sociedade.

138 Os cinco séculos de evangelização da América Latina sem dúvida fizeram penetrar a fé cristã no coração de nossos povos. A América Latina é hoje o continente com maior número de batizados na Igreja Católica. Ainda não foi possível aprofundar a formação. As grandes massas são integradas por católicos batizados, mas incapazes de dar razão de sua fé e, por isso indefesos diante do proselitismo das seitas, sobretudo quando, além de falar de Deus e das Sagradas Escrituras, prometem curas e bemestar material. A isso se deve acrescentar o sincretismo, não raro marcado por doutrinas espiritas, como no Brasil, onde existe, entre católicos, uma crença bastante difundida na reencarnação. ALMEIDA, D. L. M., O pensamento episcopal latino-americano, do Rio a Santo Domingo, in: O futuro da reflexão teológica na América Latina (CELAM), 1998, p. 18.

139 Primero, la Santa Sede reconoce la possessio de Portugal sobre las tierras descubiertas y por descubrir. En segundo lugar, dicho poder es exclusivo -sobre todo con respecto a Africa-. Tercero, el que procediera de un modo contrario sería objeto de excomunión. En cuarto lugar, dicho poder es también económico, es decir, fundamento del colonialismo que nacía lentamente. Además, el Papado daba a la Corona portuguesa un derecho y un deber, es decir, el jus patronatus y el deber de la «propagación de la $\mathrm{Fe}$ » entre los pueblos descubiertos o arrebatados al poder sarraceno. Es la primera vez en la historia que el Papado -o la Iglesia- otorga a una nación el doble poder de colonizar y misionar, es decir, mezcla lo temporal y lo sobrenatural, lo político y lo eclesial, lo económico y lo evangélico, produciendo de hecho algo así como una teocracia expansiva y militar -de tipo más bien islámico que cristiano, pero frecuente en la Edad Media-. Este equívoco se sitúa como base de toda la empresa portuguesa y española de colono-evangelización o de misio-colonización. Por último, las Órdenes Militares podían constituir como territorium nullius Diocesis las tierras descubiertas bajo la protección directa de la Santa Sede, lo que posibilitaba una mayor libertad. DUSSEL, E., Historia de la Iglesia en America Latina, 1992, p. 81

${ }^{140}$ Puebla, 6 
Se a Igreja tem em seu seio cristãos de nações desenvolvidas, ricas e dominantes, de classes também ricas e dominantes, e cristãos de países pobres e dominados, de classes pobres e dominadas, a Igreja se encontra, de fato, na contigência de aceitar uma tensão interna entre os termos opostos, as vezes em luta. Aceitar essa tensão, esta diferenciação, esta oposição real não é ideologia, 'paralelismo', cisma, antiinstitucionalismo. É simplesmente realismo, senso comum, saúde mental ${ }^{141}$.

Tal circunstancia fazia com que a Igreja ou se aproximasse da sociedade vinculada ao Estado e com as classes dominantes impedindo-lhe de se libertar das estruturas do status quo, ou, mantinha distância do Estado capitalista se aproximando da classe mais pobre. Assim, é possível ver dois modelos: no primeiro modelo vemos a Igreja que se aproxima do Estado autoritário, fazendo com que as relações pastorais com o povo na sociedade tivessem vínculo com o Estado. Outro modelo é o da Igreja popular que na linha do serviço, com o testemunho de martírio, pobreza e humildade, coloca-se solidariamente do lado dos pobres, mantendo distância do Estado ${ }^{142}$.

No documento de Puebla, mesmo com questionamentos e risco no que concerne ao termo "Igreja popular", mostra-se favorável a este modelo como forma de inserção do cristão à classe dos menos favorecidos "uma Igreja que procura encarnar-se nos meios populares do continente e que, por isso mesmo, surge da resposta de fé que estes grupos dão ao Senhor"143.

Tal adesão aos meios populares do continente, diz respeito àqueles setores da Igreja da América Latina que ainda estavam ligados ao poder econômico e político, de forma ainda não terem sido despertados a uma solidariedade e compromisso para com os mais pobres, pois estavam mais preocupados por uma "clientela" urbana e "pequeno-burguesa" em seus templos e celebrações litúrgicas. ${ }^{144}$.

A estrutura hierárquica da Igreja, o mesmo a imagem do clero e dos religiosos, muitas vezes denotavam uma Igreja que estava alienada e longe de conhecer os

${ }^{141}$ DUSSEL, E.; De Medellín a Sucre - 1968 - 1972, 1981, p. 25, v. I

${ }^{142}$ A Igreja é interpretada como um perigo, especialmente em seus membros que se comprometem com as classes mais necessitadas, com os pobres, cujas as posições são exageradas até confundí-las com as guerrilhas e apoiada por uma 'teologia da violência'. Ibid, 1981, p. 41, v. I

${ }^{143}$ Puebla, 263

${ }^{144}$ DUSSEL, E.; De Medellín a Sucre - 1968 - 1972, São Paulo: Edições Loyola, 1981, p. 40, v. I 
problemas da população $^{145}$.

Assim, a Igreja era vista como incapaz de perceber os sinais do tempo, se preocupando muito mais com a doutrina e com os dogmas de fé e desconfiada em relação às aspirações da sociedade latino-americana. A Igreja se encontrava, pois, distante dos pobres e dos trabalhadores bem como de seus problemas.

A Igreja também soube dessolidarizar completamente daqueles que se comprometeram com as classes oprimidas, com os mais pobres, seja porque a Igreja é praticamente um aparato ideológico do Estado ou sua força legitimadora última, ou porque tem vínculos históricos com as classes hegemônicas. Esta figura impede que a Igreja imponha toda a sua autoridade a partir de um apoio nas classes menos favorecidas, o povo, os marginalizados $^{146}$.

A Igreja teve acesso à classe dominante e a apoiava. Pedia justiça aos ricos e, muitas vezes, se apresentava omissa as necessidades dos mais pobres e trabalhadores. Os sacerdotes, religiosos e movimentos leigos eram influenciados por uma mentalidade e ideologia europeia.

As estruturas da Igreja absorviam desproporcionalmente os sacerdotes e religiosos, impedindo sua presença entre as maiorias pobres ${ }^{147}$. De uma forma geral, a Igreja na América Latina projetava para as grandes maiorias uma imagem de riqueza e ostentação. Enquanto que a maioria da população vivia na extrema pobreza, muitas lideranças eclesiásticas e comunidades religiosas não correspondiam com a situação da sociedade.

Muitas atividades da Igreja e mesmo o sistema econômico que lhe concerne

${ }^{145}$ A impressão que se tinha é que a Igreja institucional é a Igreja da qual fazem parte as nações, classes, grupos, frações dominantes, ricas, opressoras, ao passo que os oprimidos são algo assim como uma 'nova seita. Ibid, 1981, p. 26, v. I

${ }^{146}$ Ibid, 1981, p. 42, v. I

${ }^{147} \mathrm{Si}$ esto es así en los sectores más directamente responsables de la iglesia, se comprende que ésta, en su acción religiosa y social, se encuentre seriamente trabada para corregir en su fieles esa grave deficiencia en la comprensión y actuación de su fe Cristiana. Nuestros documentos comprueban, por el contrario, que la iglesia sigue alimentando en la América Latina una religión ritualista y conformista, que adormece al pueblo en su miseria y tranquiliza la conciencia de los poderosos; que la iglesia mantiene todavía la imagen de un Dios conservador del orden establecido, que suple la irresponsabilidad del hombre y promete la vida futura desentendiéndose de la presente. Por eso, dicen, la iglesia oficial aparece en la América Latina alienada y alienante; y así se la va sintiendo cada vez más, a medida que los cristianos - especialmente entre los jóvenes - van tomando conciencia de las exigencias de la realidad social y van descubriendo la dimensión política liberadora de su fe. MUÑOZ, R., Nueva conciencia de la Iglesia en América Latina, 1974, p. 288. 
tinha como modelo o sistema capitalista. Muitos clérigos não se punham ao serviço do povo, e em muitas vezes o discurso eclesiástico tinha como objetivo atender a burguesia $^{148}$.

Era possível perceber uma Igreja que estava dividida em dois modelos: primeiramente, vinculado a um comprometimento com o poder vigente, o segundo, por uma Igreja optando pelo serviço dos mais pobres. A atividade da Igreja para com os mais pobres fez com que surgisse uma nova forma de linguagem e de uma nova consciência, a partir da experiência de solidariedade e de apoio aos mais oprimidos. Assim, conduzia a evangelização a um processo de rompimento com o sistema injusto e iníquo ${ }^{149}$.

De princípio, tal atitude se tornava um agravante para a ação evangelizadora sendo cúmplice da burguesia. A Igreja punha em risco a imagem de libertadora dos mais oprimidos, se tornando conivente com a tranquilidade e consciência dos privilegiados.

Uma das muitas atitudes da Igreja foi mediante as obras assistenciais, no intuito de aliviar os problemas individuais, mas nem sempre agia contra as estruturas que causavam miséria. Tal atitude também não contribuía para o desenvolvimento de um senso crítico, iniciativa ou solidariedade na sociedade ${ }^{150}$. A Igreja nem sempre estava empenhada a aproximar-se dos mais necessitados, em vista de uma nova ordem socioeconômica. As ações da Igreja, que já estavam presentes desde o período colonial, exerciam uma tarefa civilizadora e assistencial, deveriam orientar-se neste

148 Muitas igrejas latino-americanas, quase todas tem uma forte vinculação na pequena e média burguesia. Esta posição hegemônica de classe faz com que a igreja tenda em certos momentos para uma crítica da alta burguesia e do Estado por seus 'excessos', e que em outros momentos - flutuações próprias de sua classe de origem e de interesses - se incline para as classes populares. Quando o compromisso com as classes populares leva a igreja até o choque sem retorno com o Estado, frequentemente as igrejas de cada país, de diferente maneira, dão 'marcha ré'. Estas práticas, as vezes contraditórias no tempo - momentos de forte impulso libertador, compromissos com pastoral popular e retrocessos, silencio e cumplicidade - , tem muito a ver com os comportamentos de pequena e média burguesia. DUSSEL, E.; De Medellín a Sucre - 1968 - 1972, São Paulo: Edições Loyola, 1981, p. 40, v. I.

${ }^{149}$ Ibid, 1981, p. 45-46, v. I.

${ }^{150}$ MUÑ̃Z, R., Nueva conciencia de la Iglesia en América Latina, 1974,p. 285 
momento histórico uma função transformadora na América Latina ${ }^{151}$. Haveria a necessidade de uma conscientização ao desenvolvimento do povo e estar atento ao serviço de libertação da sociedade. Tal conscientização poderia colaborar com uma nova transformação estrutural, tendo em vista, na época, o novo contexto sóciocultural, secularizado e pluralista da sociedade ${ }^{152}$.

A qualificação de "subversivo" e de "comunista" eram dados pela classe dominante para aqueles que incentivavam uma conscientização ou uma mudança do sistema social que mantinha seus privilégios. Tais acusações eram dirigidas contra sacerdotes e leigos cristãos. Muitos eclesiásticos aceitavam publicamente tais acusações, dando abertura a ideologias anticomunistas até mesmo dentro da Igreja As ditaturas seduzem alguns bispos, ao mesmo tempo em que perseguem os leigos, por outro lado, sacerdotes e religiosos que de acordo com as orientações da Igreja (concílio, encíclicas e Medellín) denunciam os abusos sociais e se colocavam a serviço dos pobres. ${ }^{153}$

Não obstante, é justo acentuar o papel que a Igreja recebeu, já desde os apóstolos, em sua missão de anunciar e de fazer ser conhecida a Boa Nova de Jesus Cristo. A todos os povos, a partir de sua realidade histórica, compete aos discípulos, que chamados por Cristo, dar testemunho do amor e da solidariedade em toda a sua ação evangelizadora.

$\mathrm{Na}$ América Latina, podemos encontrar a ação evangelizadora dentro de um contexto ambíguo de luz e trevas. As atuais mudanças socioculturais na América Latina não só desafiam a identidade cultural de nossos povos, mas também de sua religião.

\footnotetext{
${ }^{151}$ Ibid., 1974, p. 286

152 Ibid., 1974, p. 286

153 Ibid., 1974, p. 286-287.
} 
Hoje, no mundo todo e também na América Latina, um novo tipo de secularização convive com um forte renascimento religioso pós-moderno (...). Tratar-se-ia de uma 'secularização suave' que, não tende ao desaparecimento, mas a perda da relevância social e à reconfiguração diferente, nova, da religião da modernidade capitalista das sociedades diferenciadas e complexas ${ }^{154}$.

As desigualdades sociais, injustiças, opressão, desrespeito se tornaram palco para a ação evangelizadora, para aqueles menos favorecidos, excluídos e marginalizados ${ }^{155}$. No entanto, o ensejo à caridade e a solidariedade de muitos cristãos latino-americanos permitiram a valorização e o respeito à vida. A justiça, a dignidade humana, o respeito, se tornaram expressão por um mundo mais solidário e humano.

A própria Igreja reconhece o empenho de cristãos engajados ao comprometimento social em vista a promoção à dignidade humana ${ }^{156}$. O Papa João Paulo II expressou pela primeira vez, quando esteve no continente latino-americano, a gratidão pelos religiosos que anunciaram Cristo Salvador, defendendo a dignidade dos indígenas, proclamando seus direitos invioláveis em favorecimento de sua promoção integral, como também, ao ensinamento a fraternidade que teriam que viver como homens de um mesmo Deus que é Senhor e Pai ${ }^{157}$.

\footnotetext{
${ }^{154}$ SCANNONE, J. C., O comunitarismo como alternativa viável, in: $O$ futuro da reflexão teológica na América Latina, 1998, p. 155.

${ }^{155}$ La Exhortación apostólica Ecclesia in America reafirma una vez más la opción preferencial de la Ilesia por los pobres y marginados. Opción asumida por la Iglesia latinoamericana en Medellin y formulada con claridad en Puebla. El objetivo de dicha opción es anunciar a los pobres la Buena Nueva, anunciarles con hechos y palabras que Dios los ama. En Jesucristo se inaugura de esta manera la realización del Reino de Dios. Reino de Dios que se va manifestando en la recuperación de la plenitud de vida, en la reintegración del marginado a la vida comunitária, en la restitución del pecador a la comunión con Dios y com el Pueblo elegido, en la restauración de la fraternidad y la solidaridad entre todos los seres humanos como hijas e hijos de un solo Padre Dios. DELGADO, El amor preferencial por los pobres y marginados, in: Iglesia in América, Al encuentro de Jesucristo vivo, 2001, p. 277.

${ }^{156}$ Rerum Novarum, 17

157 João Paulo II, “Homilia Sto. Domingo”, Acta Apostolicae Sedis, LXXI, p. 154 (25/09/1979).
} 
As Conferências do Episcopado latino-americano (CELAM) nos fazem percebem o quanto a Igreja tem se empenhado pela promoção da dignidade humana $^{158}$. Em Medellín em 1968 a Igreja católica começa a tomar consciência de sua missão e abre-se, até mesmo, ao diálogo inter-religioso. Em vista de uma sociedade em que as mudanças sociais se tornam mais visíveis, a Igreja se dispõe a ação evangelizadora, no intuito de edificar uma sociedade em que possa ser mais justa, fraterna e solidária ${ }^{159}$. A solidariedade, promovida pela Igreja, atinge aquela grande maioria marginalizada, oprimida e explorada muitas vezes pelo sistema econômico e político. Desta forma, a ação evangelizadora e a mensagem de salvação são levadas a todos preferencialmente aos mais pobres e esquecidos ${ }^{160}$.

${ }^{158}$ El CELAM,los grupos cristianos en general, van tomando posición ante la realidad social, en el sentido de la reforma fundamental de estructuras. Los laicos comprometidos en sindicatos, gremios, partidos políticos representan poco a poco lo más dinámico en dichos movimientos. Al nivel de la civilización -ya que el problema de la fe y el pluralismo se sitúa el nivel del núcleo ético-mítico- la Iglesia latinoamericana (mucho más que la europea) se ha comprometido en la lucha por la justicia., DUSSEL, E., Historia de la Iglesia en America Latina, 1992, p. 202.

${ }^{159} \mathrm{El}$ intento de una «nueva cristiandad» dio sus frutos y significó un temporal renacimiento (1930962). Sin embargo, es bien posible que el camino elegido no fuese el definitivo ni, por otra parte, el más adecuado para la etapa que hemos comenzado. Sólo un hecho inesperado y del todo mayor en la historia de la salvación va a poner punto final a la agonía de la cristiandad, no porque no haya quienes luchen todavía por su nueva instauración, sino por aparecer un nuevo horizonte, un nuevo proyecto teológico, pastoral, existencial de vivir el cristianismo como antes de la cristiandad. Ese hecho inesperado ha sido el Concilio Vaticano II, que significa una nueva etapa en la historia de la Iglesia universal, pero, de manera aún más determinante, en la historia de la Iglesia en América Latina. Ibid., 1992, p. 203.

${ }^{160}$ Puebla, Introdução, 5, Ação evangelizadora Qual é, concretamente, o caminho? É necessário levar a pessoa humana e os grupos sociais: - à tomada de consciência de sua dignidade e da condição na qual se encontram; - ao compromisso da renovação de sua vida e da sociedade segundo os valores do Evangelho, através da vivência da justiça, da solidariedade humana, da participação na comunhão eclesial e da pobreza evangélica, sem ódio nem rejeição de qualquer setor social, mesmo privilegiando os pobres, sem julgar e condenar nem apelar para a violência; - à busca de uma libertação que vai além de todos os limites temporais e que tem sua plena realização na comunhão com Deus, o verdadeiro e único Absoluto" (Evangelii Nuntiandi, 19); - a uma ação com todas as dimensões do mandamento novo, que é amor inteligente e crítico (Cf. Evangelii Nuntiandi, 38). 


\section{5 - O desafio ecológico na América Latina}

A humanidade em sua fase da globalização encontrou um cenário planetário de crises, provocado pela exacerbação do modo capitalista de produção, na busca incessante de satisfazer necessidades e, consequentemente, produzindo importantes degradações no ecossistema.

O homem tem afetado o meio ambiente de várias maneiras. O ser humano, ao servir-se da natureza para existir e viver tem provocado, por ignorância ou irresponsabilidade, muitos problemas que, devido à superpopulação do mundo atual, causam preocupações a todos nós.

Com relação aos países mais ricos e os mais pobres, podemos dizer que os problemas ecológicos podem ser apresentados de maneiras muito diferentes. Esta diversidade de situações demonstra como a interação entre fatores econômicos (pressão dos mercados, capacidade produtiva e tecnológica instalada etc.), culturais (percepção da degradação ambiental, tradições) e políticos (participação efetiva dos grupos sociais, legislações mais ou menos voltados para o bem comum) condicionam as relações entre as sociedades e seu meio ambiente. Os problemas ambientais podem ser entendidos como o resultado de um desequilíbrio entre as formas de exploração dos recursos naturais, o poder dado pelas tecnologias disponíveis e os condicionamentos político-culturais de uma sociedade.

A atual sociedade mundializada se propôs um objetivo questionável: explorar todas as riquezas naturais visando à acumulação de riqueza, sem qualquer consideração nem limite. Neste propósito, nos trouxe inegáveis facilidades para a vida, como o antibiótico, a cultura industrial que tornou mais leve nossa existência e outra vantagens. Mas produziu também duas consequências iníquas: uma injustiça social clamorosa, fazendo que $20 \%$ da humanidade se aproprie da maioria das riquezas e deixando $80 \%$ na indigência. Simultaneamente produziu uma espantosa injustiça ecológica, dizimando inteiros ecossistemas e devastando a Terra a ponto de ela hoje mostrar sinais de extenuação pelo aquecimento global e pela perda da biodiversidade ${ }^{161}$.

Torna-se abusivo o clamor dos países mais ricos quando afirma que a crise ecológica é devida o crescimento demográfico dos países mais pobres. A febre

${ }^{161}$ BOFF, L., A casa comum, a espiritualidade, o amor, 2017, p. 65 
consumista e estimulada pela necessidade de produzir mais, a fim de alcançar maiores dividendos, faz com que a degradação do meio ambiente seja promovida com maior intensidade nos países mais ricos. Não obstante, os países mais pobres, em busca de um desenvolvimento, acabam percorrendo o mesmo percurso que os países mais desenvolvidos, repetindo os mesmos erros que tem levado a civilização industrial, ou seja, a destruição da natureza.

A degradação do ecossistema é expressa pela crescente deterioração e esgotamento de recursos naturais não renováveis e pelas diversas poluições da atmosfera, dos solos e das águas. A isto converge o aquecimento global, ligado às emissões de gases que produzem o "efeito estufa", associado ao modelo de desenvolvimento industrial e do consumismo, que se orientam pela lucratividade do capital, sustentado pela ideologia de que o "crescimento da produção e do consumo" beneficiaria, em longo prazo a melhoria do bem-estar de toda a humanidade. Esta "promessa" não se concretizou; ao contrário, se tornou cada vez mais distante a mais de um bilhão de seres humanos, o que traria um efeito devastador no meio-ambiente.

Podemos perceber que em cada contexto econômico, social e cultural, a forma pela qual as populações humanas se relacionam com o meio ambiente são condicionados por uma serie de fatores. Supõe-se que os países mais pobres teriam problemas muito maiores com que se ocupar, sendo o desafio ecológico uma abordagem de luxo para os países mais ricos. É claro que para os países mais pobres a industrialização se apresenta como insuficiente no oferecer bem-estar para a maioria da população, a marginalização, fome, miséria, educação se tornam prioritários ${ }^{162}$.

A temática do meio ambiente na América Latina, tem uma atualidade incomparável em vista da série de problemas econômicos e sociais que já afetam a região. Entre estes, não se pode esquecer o modo de produção histórica dentro de um modelo extrativista e dependente. Com a industrialização local surgem novas exigências e dependências dos países centrais. Isto gera uma exploração dos recursos naturais, que produzem dejetos industriais extremamente poluidores do solo, das

162 ONGs veem cenário brasileiro preocupante para os objetivos globais da ONU, conferir em: https://nacoesunidas.org/ongs-veem-cenario-brasileiro-preocupante-para-os-objetivos-globais-da-onu/ 
águas e do ar. Os desequilíbrios daí decorrentes afetam o meio ambiente, a estrutura urbana, a estrutura econômica e a estrutura social, pelas diferentes formas de exclusão e de pobreza geradas.

A consideração pela questão social da ecologia deve começar com a situação dos pobres, em que a própria vida está sob grande ameaça. Os pobres são as maiores vítimas dos desastres ecológicos que exprerimentamos hoje, porque têm menos meios de se proteger ${ }^{163}$.

A presença das indústrias nos países da América Latina acentua o alargamento das condições produtivas, a ponto de multiplicar indefinidamente o excedente econômico e ampliar o espaço de mercado. O crescente avanço tecnológico possibilita novas fontes de energia para que as máquinas melhorem a eficiência do trabalho humano, surgindo um sistema operacional, mais organizado. "A ciência e a tecnologia foram colocadas a serviço da industrialização impulsionada pelo liberalismo e pelo capitalismo. Esse é o verdadeiro contexto cultural da atual crise ecológica ${ }^{164 "}$.

Vemos a introdução de novas fontes energéticas (eletricidade, motor de combustão etc.), que expandem os setores industriais, implantam vias de transporte e demais infraestruturas, novas indústrias emergem, novos conceitos de gestão e administração são adotados, hierarquiza-se a estrutura empresarial com o surgimento de novos investidores etc. Os avanços na tecnologia de energia, no setor de transporte, na área de produtos elétricos etc. É a fase da urbanização acelerada e a crescente demanda de eletrodomésticos, em substituição do trabalho humano na área doméstica.

A industrialização das sociedades periféricas às sociedades centrais insere-se no processo de modernização, pelo qual sociedades agrárias dependentes se industrializam e se urbanizam. Incluem-se, nesta categoria, os países latinoamericanos, alguns apontados como "emergentes": Brasil, Argentina, Chile, México,

\footnotetext{
${ }^{163}$ BINGEMER, M. C., Teologia Latino-Americana, Raízes e Ramos, 2017, p. 100.
}

164 JUNGES, J. R., Ecologia e Criação, 2001, p. 16. 
Rússia, China, Índia e outros similares ${ }^{165}$. Além das diferenças históricas e culturais, há convergências quanto à questão da tecnologia, da produtividade e da relação com o meio ambiente.

As nações latino-americanas que tiveram um passado de colonização predadora e de extrativismo, ao se lançarem na corrida industrial, importaram tecnologias, algumas adequadas e outras tantas inadequadas, compraram máquinas etc., na intenção de melhorar os procedimentos produtivos ${ }^{166}$. Com o modelo produtivo, importou-se a cultura da devastação dos recursos naturais e, rapidamente, constatou-se a insustentabilidade do modelo, na medida em que ele se alimenta de novas áreas fornecedoras de recursos naturais o que exige desmatamentos, destruição do solo e do subsolo, levando à contaminação de águas e da atmosfera pelos dejetos produzidos.

165 A comensalidade é tão importante que faz parte da essência do ser humano. "Entre os países centrais e os periféricos se estabeleceram uma verdadeira guerra comercial por alimentos. Os países ricos subsidiam a produção agrícola e bovina para colocá-la a melhor preço no mercado mundial, prejudicando destarte os países pobres, cuja principal riqueza consiste exatamente na produção e exportação de produtos agrícolas e de carnes. Muitas vezes para se viabilizarem economicamente, estes últimos se obrigam a exportar cereais que irão alimentar o gado dos países centrais quando poderiam servir de alimento para suas populações no mercado interno" BOFF, L., Virtudes para um outro mundo possível. v. 3. Comer e beber juntos e viver em paz. 2006, p. 30-31.

166 Podemos citar como exemplo os transgênicos. "Transgênicos resultam da transferência e alteração de genes de um ser vivo (vegetal, animal, ser humano, micro-organismo) ao outro com o propósito manifesto de torná-lo mais saudável, produtivo e mais imune a pragas e a bactérias. Em muitos produtores, porém, vigora também o propósito oculto de fazer mais negócios e acumular vantagens financeiras. A questão é altamente polêmica e envolve várias instâncias: os produtores, o mercado, os consumidores (...). Os produtores querem transgênicos, alegando diminuição de custos e aumento da produtividade, inicialmente em $20 \%$, com vantagem de criar plantas mais resistentes a pragas. A crescente demanda mundial por alimentos reforçaria esse propósito. O mercado busca ganhos. Algumas empresas mundiais (cinco ao todo) produzem sementes transgênicas que vão lentamente substituindo as naturais (erosão genética das sementes creoulas). Mas acabam monopolizando o mercado de sementes (uma delas controla 90\%), tornando os produtores econômica e tecnologicamente dependentes (...). Os consumidores relutam em consumir alimentos geneticamente modificados por recearem consequências funestas sobre a saúde no presente e no futuro. A ciência não consegue fornecer total segurança, pois sobre cosequencias futuras não se pode ter segurança total, apenas hipotéticas previsões (...)" BOFF, L., Virtudes para um outro mundo possível. v. 3. Comer e beber juntos e viver em paz. 2006, p. 35-36. 
Aprofundando a questão da fome, nos damos conta de que ela resulta de uma filosofia sugjacente a todo processo produtico humano. $\mathrm{O}$ alimento se transformou uma ocasião de lucro e o processo agroalimentar num negócio rentoso. Produz-se mais visando o lucro do que criar meios de vida acessíveis ao maior número possível de pessoas. A agricultura, mais do que a arte e a técnica de produção de meios de vida, se transformou num empreendimento para auferir ganhos financeiros. Mediante a mecanização e a alta tecnologia pode-se produzir muito mais com muito menos terra. A 'revolução verde', introduzida a patir dos anos 70 do século XX e difundida em todo mundo, quimicalizou grande parte da alimentação ao utilizar intensivamente irrigação, fertilizantes artificiais, pesticidas, sementes híbridas e geneticamente modificadas. Os efeitos são perceptíveis agora: empobrecimento dos solos, devastadora erosão, desflorestamento, diminuição dos rios e a perda de milhares de variedades naturais de sementes, importantes como reservas face a crises futuras ${ }^{167}$.

A região da América Latina e o Caribe possuem uma área em torno de dois bilhões de hectares, que corresponde à cerca de $15 \%$ da área total da Terra, contendo a maior variedade de espécies naturais e ecossistemas do mundo. Um grande desafio da América Latina está no corte ilegal de madeira e no desflorestamento. Estima-se que o corte ilegal de madeira seja o dobro do da legal. A falta de fiscalização, o desmatamento desenfreado ${ }^{168}$, principalmente na região amazônica, gera o extermínio de inúmeras espécies de animais e plantas que fazem parte de nosso continente.

A região da América Latina e Caribe é rica em recursos naturais renováveis, particularmente águas interiores, contribuindo com $30 \%$ do total mundial, destacando-se três regiões hidrográficas: a Bacia do Golfo do México, a Bacia do Atlântico Sul e a Bacia do Rio da Prata. Os problemas hídricos regionais transcendem as fronteiras territoriais nacionais ${ }^{169}$, que podem ser resumidos nos seguintes desafios: diminuição da disponibilidade per capita de água devido ao crescimento populacional; expansão urbana; desmatamento e mudanças climáticas; deterioração

167 BOFF, L., Virtudes para um outro mundo possível. v. 3. Comer e beber juntos e viver em paz. 2006, p. 29-30.

168 FAO: países já têm conhecimento para acabar com desmatamento, mas falta vontade política, conferir em https://nacoesunidas.org/fao-paises-ja-tem-conhecimento-para-acabar-com-desmatamentomas-falta-vontade-politica/

${ }^{169}$ Não poderíamos, junto com o problema da fome e da segurança alimentar, deixar de tratar da grave questão da água. Ela pertence à alimentação, pois não há nenhum alimento que dispense a água e não há ingestão que prescinda da água. (...). Existe cerca de 1,3 bilhão de $\mathrm{km}^{3}$ de água na Terra. Isto significa que, se distribuirmos toda essa água que está nos oceanos, lagos, rios, aquíferos e calotas polares equitativamente sobre a superfície terrestre, a Terra ficaria submersa na água a $3 \mathrm{~km}$ de profundidade. Esse total está distribuído em $97 \%$ de água salgada e de 3\% de água doce. Isso equivale a 8,5 milhões de $\mathrm{km}^{3}$, dos quais somente $0,7 \%$ são diretamente acessíveis ao uso humano. BOFF, L., op.cit., 2006, p. 41-42. 
da qualidade da água em função da falta de tratamento de esgoto; uso excessivo de fertilizantes, pesticidas e poluição industrial, aliado ao uso de ferramentas legais e institucionais ultrapassadas.

Mesmo que a América do Sul seja uma região rica em recursos hídricos, o consumo de água vem aumentando nas últimas décadas devido ao crescimento populacional, ao desenvolvimento agrícola e industrial ${ }^{170}$. Na maior parte dos países da região, sobretudo da América da Sul, prevalece à cultura do desperdício, pela qual se busca aumentar o suprimento de água, ao invés de empregar medidas de conservação e uso racional de água.

Não há problema de escassez de água mas de má gestão para atender as demandas humanas e dos demais seres vivos. O Brasil é a potência natural das águas, com $13 \%$ de toda água doce do planeta, perfazendo 5,4 trilhões de $\mathrm{m}^{3}$. Mas é desigualmente distribuída: $70 \%$ na região amazônica, $15 \%$ no Centro-Oeste, $6 \%$ no Sul e no Sudeste e $3 \%$ no Nordeste. Apesar da abundância, não sabemos usar a água, pois $46 \%$ dela é desperdiçada, o que daria para abastecer toda a França, a Bélgica, a Suíça e o Norte da Itália. É urgente, portanto, um novo padrão cultural. A água doce, por causa de sua escassez, é vista como recurso hídrico e bem econômico. Ela virou mercadoria e fonte de lucro $^{171}$.

As principais causas da poluição atmosférica na região são: a quantidade e a qualidade dos combustíveis consumidos; o crescimento do número de veículos, aliado ao controle inadequado de suas emissões, agravado pela prática crescente de importar veículos usados; atividades industriais; alta densidade demográfica nas áreas urbanas; uso de pesticidas em comunidades rurais; emissões produzidas pela erosão do solo e, em algumas cidades, condições desfavoráveis para dispersão de poluentes. De todas estas causas, a emissão veicular é a mais séria, afetando especialmente os grandes centros urbanos ${ }^{172}$.

Em anos recentes, progressos substanciais foram obtidos no controle de poluição do ar das grandes cidades, tais como São Paulo, Rio de Janeiro, Buenos

\footnotetext{
${ }^{170}$ CEPAL diz que austeridade não deve tirar água e saneamento das prioridades públicas, conferir em: https://nacoesunidas.org/cepal-diz-que-austeridade-nao-deve-tirar-agua-e-saneamento-das-prioridadespublicas/

${ }^{171}$ BOFF, L., Virtudes para um outro mundo possível. v. 3. Comer e beber juntos e viver em paz. 2006, p. 42-43.

172 Agências da ONU se unem para combater riscos ambientais de saúde, conferir em: https://nacoesunidas.org/agencias-da-onu-se-unem-para-combater-riscos-ambientais-de-saude/
} 
Aires, Santiago e México, por meio de estratégias que incluem controle de emissão, mudanças nos combustíveis e controle de contingência.

A geração de resíduos sólidos é um dos principais problemas ambientais enfrentados pela sociedade humana. Considerando que a humanidade utiliza cerca de $40 \%$ de todos os recursos primários do Planeta, tem-se que uma parcela significativa de resíduos sólidos, de origem domiciliar, industrial e de serviços (saúde, comercial, entre outros), é gerada diariamente, como resultado da conversão desses recursos. $\mathrm{O}$ processo de urbanização, aliado ao consumo crescente de produtos menos duráveis e/ou descartáveis, também vem provocando um aumento do volume e diversificação dos resíduos sólidos gerados.

Vale ressaltar de que a destinação adequada de resíduos sólidos, seja de origem domiciliar, industrial ou de serviços (saúde, comercial, entre outros), constitui um dos principais desafios ambientais da atual e das próximas décadas, pois há uma necessidade cada vez maior de minimizar esses resíduos, por meio de ações de redução, reúso, reciclagem e reaproveitamento energético, associado a procedimentos para o monitoramento e controle desses resíduos ${ }^{173}$.

Muito se tem feito para despertar a consciência daquilo que é necessário para encontrar novos modelos de desenvolvimento mais justo e solidário, bem como mais capazes de respeitar o meio ambiente. A Igreja, tem-se esforçado, a partir de campanhas sociais, na conscientização por uma transformação social e pelo cuidado do meio-ambiente.

Os textos da Campanha da Fraternidade, o documento do CELAM (Puebla), já apontam uma reflexão de uma crise ecológica. Mais recentemente, o Papa Francisco emite a carta encíclica Laudato Si mostrando a preocupação da Igreja relativamente ao meio ambiente e ao cuidado da natureza. "Espero que esta carta encíclica, que se insere no magistério social da Igreja, nos ajude a reconhecer a

173 ONU: América Latina e Caribe despejam 30\% de seu lixo em locais inadequados, conferir em: https://nacoesunidas.org/onu-america-latina-e-caribe-despejam-30-de-seu-lixo-em-locais-inadequados/ 
grandeza, a urgência e a beleza do desafio que temos pela frente (...) a actual crise ecológica". (LS 15)

O Papa Francisco acentua questões importantes a serem refletidas em sua encíclica, tais como:

(...) a relação íntima entre os pobres e a fragilidade do planeta, a convicção de que tudo está estreitamente interligado no mundo, a crítica do novo paradigma e das formas de poder que derivam da tecnologia, o convite a procurar outras maneiras de entender a economia e o progresso, o valor próprio de cada criatura, o sentido humano da ecologia, a necessidade de debates sinceros e honestos, a grave responsabilidade da política internacional e local, a cultura do descarte e a proposta dum novo estilo de vida. Estes temas nunca se dão por encerrados nem se abandonam, mas são constantemente retomados e enriquecidos. (LS 16)

Devido a complexidade em dar uma resposta aos desafios ecológicos, como a problemática do desenvolvimento, a utilização dos recursos naturais e o próprio bemestar do homem, vemos a necessidade em explorar outros campos como forma de impulsionar ou até mesmo criar novos modelos de relacionamento, que instaure um envolvimento entre o homem e o meio ambiente. A teologia pode ajudar nesta reflexão, que pode levar a uma mudança de perspectiva do ser humano com o cosmo a partir da fé bíblica ${ }^{174}$. A fé cristã ocupa um lugar fundamental numa teologia ecológica, pois este Deus de comunhão e relação, inserido no mundo, promove uma relação de mútua de inclusão e interação com a obra criada. Com efeito, se Deus se insere na obra criada, pois esta é a proposta da revelação divina, o homem, criado a

174 Os teólogos da libertação começaram a expandir suas esperanças e perspectivas, como também a verem que o processo de libertação não é só sobre a pobreza em nível sócio-econômico-político, mas também em nível antropológico e cultural - sobre gênero, raca e etnia. Ademais, a libertação passou a ser entendida não só como algo para seres humanos, mas para toda a criação. As preocupações e as lutas ecológicas passaram a ser vistas como inseparáveis dos temas econômicos e antropológicos. Ecologia, sustentabilidade e a preocupação pela vida do planeta foram, então incluídas na agenda da Teologia da Libertação. Construir um mundo habitável tornou-se um desafio que coincide com o empoderamento do povo para se tornar sujeito da própria história. Esse movimento começou com a convicção de que tudo o que prejudica os seres humanos também é prejudicial ao planeta. Além disso, foi reconhecido que se a raça humana continuasse a destruir a natureza e a vida em todas as suas manifestações, logo ela mesma deixaria de existir. A inseparabilidade entre a luta pela justiça e a luta pela natureza e pela biodiversidade tornou-se um componente central nas preocupações teológicas. A causa ecológica é natural ao espírito da libertação. A Teologia da Libertação entende o ser humano em comunhão com todo o cosmos. O mesmo Deus da vida que privilegia o pobre também revela o status sagrado da criação, que por sua vez, é esvaziada e violada pela sociedade consumista. A Teologia da Libertação implora, portanto, por uma nova aliança cósmica e solidária, rejeitando, assim, toda dominação e exploração. BINGEMER, M. C., Teologia Latino-Americana, Raízes e Ramos, 2017, p. 89-90. 
imagem e semelhança de Deus, deve mudar radicalmente sua maneira de situa-se no interior do ecossistema de que faz parte.

Dentro desta perspectiva, encontramos o teólogo brasileiro Leonardo Boff que nos faz refletir acerca do cuidado e da compaixão pelos outros e pelo Planeta Terra, em sua obra Saber Cuidar ${ }^{175}$. Nesta obra, o autor direciona o leitor a fazer uma reflexão crítica sobre os problemas do mundo, em que a falta de atitudes de cuidado são os sintomas dos maiores problemas da humanidade. De acordo com Leonardo Boff, a degradação ambiental do planeta, as relações superficiais entre as pessoas e a falta de conhecimento de si mesmo, levam a falência da Terra.

Ao utilizar de fábulas e mitos para apresentar a origem do homem e o significado do cuidado, sendo uma das características do ser humano, apresenta uma crítica ao realismo materialista, a então filosofia da sustentação cientificismo tecnicista atual, tecendo uma crítica acerca da razão analítica ditame da nossa sociedade pós-moderna, sociedade esta que se configura pelo encapsulamento do existir, um existir individual, que não oferece espaço para o cuidado.

Portanto, em vista dos inúmeros agravantes dos quais já elencamos dentro do nosso contexto latino-americano, compreendemos que a reflexão sobre a práxis transformadora, em nosso meio ambiente, precisa em muito ser desenvolvida. Ao ver a realidade na qual estamos inseridos, muitos modelos de conscientização poderão ser desenvolvidos e apresentados.

A Terra em sua biografia conheceu cataclismos inimagináveis, mas sempre sobreviveu. Sempre salvaguardou o princípio da vida e de sua diversidade. Estimamos que agora não será diferente. Há chance de salvamento. Mas para isso devemos percorrer um longo caminho de conversão de nossos hábitos cotidianos e políticos, privados e públicos, culturais e espirituais. A degradação crescente de nossa casa comum, a Terra, denuncia nossa crise de adolescência ${ }^{176}$.

Não podemos falar de uma transformação social e ecológica desvinculando o homem do cosmo, pois caso contrário, com a destruição do meio ambiente, a autodestruição da espécie humana estaria perigosamente próxima.

\footnotetext{
${ }^{175}$ BOFF, L., Saber cuidar: Ética do humano - compaixão pela terra, 2017, p. 19
}

${ }^{176}$ BOFF, L., Saber cuidar: Ética do humano - compaixão pela terra, 2017, p. 17. 
Formalizando a questão, podemos dizer: mais que o fim do mundo estamos assistindo ao fim de um tipo de mundo. Enfrentamos uma crise civilizacional generalizada. Precisamos de um novo paradigma de convivência que funde uma relação mais benfazeja para com a Terra e inaugure um novo pacto social entre os povos no sentido de respeito e de preservação de tudo o que existe e vive. Só a partir desta mutação faz sentido pensarmos em alternativas que representem uma nova esperança $\mathrm{a}^{177}$.

${ }^{177}$ Ibid., 2017, p. 17-18. 


\section{CAPÍTULO II. A doutrina da descida de Cristo a morada dos} mortos

\section{1 - A descida de Cristo aos infernos: Os fundamentos bíblicos} da doutrina.

Os 'infernos' (não confundir com o inferno da condenação) ou mansão dos mortos, designam o estado de todos aqueles que, justos ou maus, morreram antes de Cristo ${ }^{178}$.

Ao falar da descida de Cristo à mansão dos mortos, o Símbolo Apostólico utiliza, para afirmar um conteúdo de nossa fé, a linguagem de uma cosmologia que não pertence a nosso contexto cultural, ocidental e moderno. O estudo de tal artigo deve, pois, começar com a apresentação do pensamento no qual ele surgiu, especificamente, o universo bíblico ${ }^{179}$, que pensavam e diziam os povos da Escritura acerca da morte e do lugar dos mortos, quer do antigo, quer do Novo Testamento. Como veremos que a compreensão dos antigos acerca de tais temas, em razão da própria complexidade do assunto, não era uniforme, mas comportava contradições e até mesmo uma evolução.

Apresentaremos, a seguir, os textos do novo Testamento que tradicionalmente são utilizados como base bíblica para a afirmação da descida de Cristo aos infernos ${ }^{180}$, procurando analisar até que ponto se justifica tal utilização.

\footnotetext{
${ }^{178}$ CCEC, 125.

${ }^{179}$ Como veremos, a primeira "profissão de fé" a fazer menção da descida de Cristo aos infernos, a fórmula do IV Sínodo de Sírmio, ao mencionar o artigo faz explícita referência a uma passagem bíblica, Jó 38,17b.

${ }^{180}$ Obviamente os textos do Antigo Testamento só podem ser associados ao tema de modo alegórico, simbólico; por isso trataremos deles apenas quando mencionados no Novo Testamento, omitindo aqueles (como Jó 38,17b) que apenas a alegoria patrística ou medieval interpretaram como relacionados ao Descensus.
} 


\subsection{1 - A morada dos mortos. O universo semita.}

Os antigos semitas imaginavam o universo como constituído de três partes distintas. Acima ficava o céu, entendido como uma grande cúpula (Is 40,22b; 45,12; S1 104,2) ${ }^{181}$; apoiada por pilares (Jó 9,6: "abala a terra desde os fundamentos e faz vacilar suas colunas"). O firmamento separava as águas superiores das águas inferiores, que ficavam na terra (Gn 1,6-8); nele se encontravam janelas que se abriam ocasionando as chuvas (Gn 7,11; 2Rs 7,2a. 19). Acima da cúpula e das águas superiores ficava a morada dos deuses, ou, para o povo judeu, o trono de Iahweh ( $\mathrm{Sl}$ 11,4; Sl 103,19). Sendo o céu normalmente considerado constituído por vários andares ${ }^{182}$, a palavra que o designava era normalmente utilizada no plural: "Louvai-o, céus dos céus, e vós, águas de cima dos céus" (S1 148,4).

A terra era imaginada como um disco achatado, repousando sobre as águas (Gn 49, 25; Ex 20,4; S1 24,2; S1 136,6), ou sustentado por pilares, cujas bases se encontram nas profundezas do mundo inferior (S1 24,2; Sl 104,5; Jó 38,4); quando estes pilares tremiam provocavam os terremotos (S1 18,8). Sob a terra havia massas de água das quais nasciam fontes, que se tornavam os rios ( $\operatorname{Gn} 7,11 ; 8,2 ; \operatorname{Pr} 8,28)$, os quais fluíam para as águas do mar (Ecl 1,7: "Todos os rios correm para o mar e, contudo, o mar nunca se enche: embora chegando ao fim do seu percurso, os rios continuam a correr" $)^{183}$. Se o céu era considerado o trono de Deus, a terra era o escabelo de seus pés (Is 66,1). Por fim, debaixo da terra estava o mundo inferior, a morada dos mortos, o Sheol.

${ }^{181}$ As citações das Escrituras serão feitas com base em Bíblia de Jerusalém.

182 Para os babilônios havia três céus, sendo que o deus supremo residia na parte superior MARCHADOUR, A. Morte e Vida na Bíblia, 2001, p. 7.

${ }^{183}$ Se tal visão nos parecer ingênua; basta compará-la com uma narrativa árabe da criação do mundo para ver como é sóbrio o relato bíblico: "Portanto, o mundo está apoiado sobre os ombros de um anjo, que está sobre uma grande esmeralda verde, que está sobre os chifres ou o dorso de um touro, que por sua vez se apóia sobre as costas de uma grande baleia (ou dragão, segundo alguns), que nada em um grande oceano sustentado pelo ar, que finalmente está envolto em trevas, onde os corpos celestes se manifestam em certas estações do ano. O que há por trás das trevas? Só Alá sabe" HANAUER, J. E., Mitos, lendas e fábulas da Terra Santa, 2005, p. 16. 
A ideia que se tinha do Sheol ${ }^{184}$ depende, obviamente, da compreensão que se tem acerca da morte e da possibilidade de subsistência após ela. A morte como um fenômeno misterioso, desperta reações diversas, complexas e contraditórias; esta complexidade encontrava-se presente no pensamento dos antigos judeus, pelo qual seria impreciso afirmar apenas uma única concepção da morte no Antigo Testamento, antes, os textos vetero-testamentários indicam que diferentes concepções acerca da morte pareciam coexistir, sem que se notasse contradição entre elas ${ }^{185}$.

Fundamentalmente, o Antigo Testamento declara que o homem não é imortal e que nele nenhum aspecto é eterno (Nm 23,10; Jz 16,30; Ez 18,4.20). Na Bíblia, a morte parece como um fato normal que atinge todo o ser humano: "Quem viverá sem ver a morte, para tirar sua vida das garras do Xeol?" (S1 89, 49) ${ }^{186}$.

Conforme a antiga antropologia judaica, não há nenhuma parte do homem que possa escapar da morte. "A distinção entre alma e corpo é estranha à mentalidade hebraica e, por consequência, a morte não é considerada como separação entre esses dois elementos. Uma pessoa viva é uma 'alma (nepeš) vivente', um morto é uma 'alma (nepeš) morta'; Nm 6,6; Lv 21,1; Nm 19,13”'187.

184 Š.'ōl tem sido associado ao verbo šā'al que significa: perguntar, requerer, e neste caso seria o lugar em que os mortos são interrogados e julgados. Pode evocar também a profundidade do mundo subterrâneo e seria proveniente de š'l, estar no profundo. Pode indicar o lugar onde se põe o sol, visto frequentemente como a entrada para o mundo infernal. O radical š'h significa "estar deserto" (Is 6,11; $\mathrm{Na}$ 1,5). O Sheol seria a terra sem vida, o mundo caótico, o não mundo. E, por fim, Sheol pode equivaler do termo babilônico šuâru, a residência de Tamuz, e de maneira geral, o reino dos mortos. (cf. MARTIN-ACHARD, R., Da morte à Ressurreição segundo o Antigo Testamento, 2005, p. 54).

${ }^{185} \mathrm{O}$ Antigo Testamento não escapa desta complexidade. Seu testemunho confirma ainda mais a dificuldade que experimenta o ser humano para encontrar uma explicação lógica para o problema da morte. Por outro lado, está constituída por diversas tradições escalonadas no tempo, que se sobrepõe umas às outras; finalmente elas partem de uma psicologia diferente da nossa que aceita perfeitamente afirmações que para nós nos parecem excluir. Em tais condições, pode parecer arriscado traçar um quadro preciso da evolução das doutrinas israelitas acerca da sorte dos mortos. (Ibid. pp. 33-34).

${ }^{186}$ Manteremos nas citações da Bíblia de Jerusalém a grafia "Xeol", utilizando a forma "Sheol" (mais comum) nos outros casos; Cf. em figura 1 (p. 285) a imagem proposta por WEISER, A., O que é milagre na Bíblia, 1978, p. 14.

187 VAUX, R., Instituições de Israel no Antigo Testamento, 2004, p. 80. 
O Antigo Testamento, em sua maior parte, desconhece a crença que a alma é imortal; a alma não era tida como essencialmente superior ao corpo e nem poderia viver sem ele, não pertence a uma realidade incriada para ser imperecível ${ }^{188}$.

Seguindo essa concepção, em diversas passagens bíblicas, o Sheol aparece como sinônimo da morte e da sepultura, como o fim último do homem (S1 55,16; ver ainda 1Rs 2,6.9; Jó 21,13). Apresentado como um fosso, um lugar de trevas, vermes e pó, parece representar apenas o túmulo.

Ora, minha esperança é habitar no Xeol e preparar minha cama nas trevas. Grito à cova: 'Tu és meu pai!'; ao verme: 'Tu és minha mãe e minha irmã!' Pois, onde, onde então, está minha esperança? Minha felicidade, quem a viu? Descerão comigo ao Xeol, baixaremos juntos ao pó? (Jó 17,13-16) ${ }^{189}$.

Alguns textos porém, contradizendo o que foi acima afirmado, sugerem que a morte não fosse o fim da existência ${ }^{190}$, com ela não acontecia um desaparecimento completo, o homem prosseguiria, porém, em tal condição já não mereceria ser chamada de vida: as forças vitais seriam reduzidas, como num sono profundo do qual é impossível despertar-se. Segundo tal posição, a existência do morto assemelha-se a uma sombra, seres sem consistência, numa situação miserável. Os mortos

188 A propósito, ver o comentário de J.V. LINDEZ, sobre o Eclesiastes: Quanto ao fato mesmo de morrer, a igualdade é total: como morrem uns, morrem os outros. Já tínhamos ouvido falar da mesma sorte do sábio e do néscio em 2,14s; mas a igualdade com o animal é algo novo. É um fato que se contempla cada dia em nossa vida. Qohélet não se contenta com afirmar o evidente; reflete e busca uma explicação que se vai fundamentar no mais conhecido da tradição de Israel. Porque a sentença: todos têm o mesmo alento (ruah), sem dúvida se inspira no Gênesis, ainda que nem sempre utilize o termo ruah, mas outros equivalentes. Assim, em Gn 2,7 diz-se do homem que se converteu em ser vivo (nepesh hyyah), o mesmo que se diz dos animais em Gn 2,19; também segundo Gn 2,7 o homem tem alento de vida (nishmat hyyim), como animal segundo Gn 7,22. Por essa razão afirma também Qohélet que o homem não supera os animais: se o alento vital ou o princípio de vida é o mesmo para uns e para outros, e o final é o mesmo Qohélet não vê razão alguma para afirmar diferenças nestes aspectos, os fundamentais para ele. LÍNDEZ, J. V., Eclesiastes ou Qohélet, 1999, pp. 245-246.

${ }^{189} \mathrm{Em}$ numerosas passagens, o Xeol significa só a morte ou a sepultura, e descer ao Sheol equivale a morrer. De alguém que teve uma tranqüila morte natural se diz que desceu ao Xeol em paz (1Rs 2,6.9; Jó 21,13) e alguém cujos últimos anos foram amargurados pela dor desce ao Xeol com tristeza (Gn 37,35; 42,38; 44,29.31). MACKENZIE, J.L., Dicionário Bíblico, 1983, p. 972. Na maioria das vezes, a menção da descida à לש̣ como mundo dos mortos não significa mais do que a referência ao enterro como fim da vida (Gn 42.38; 44.29,31; Is 38.10,17; S1 9.16,18; 16.10; 49.10,16; 88.4-7,12s; Pv 1.12) WOLFF, H. W., Antropologia do Antigo Testamento, 2007, p. 167; mantivemos as citações bíblicas do modo apresentado na obra.

190 A morte não é um aniquilamento: enquanto subsiste o corpo, ou pelo menos enquanto dura a ossada, subsiste a alma, em um estado de debilidade extrema, como uma sombra na morada subterrânea do šheol. Jó 26,5-6; Is 14,9-10; Ez 32,17-32. VAUX, R., Instituições de Israel no Antigo Testamento, 2004, p. 80. 
("refaim"191), habitantes do Sheol, aparecem como seres impotentes, sem brilho, condenados a conhecer uma existência triste no mundo do pó.

Característica fundamental dos refaim é sua inatividade, os mortos estão completamente inativos no Sheol: Os vivos sabem ao menos que morrerão; os mortos, porém, não sabem nada. Não há para eles retribuição, uma vez que sua lembrança é esquecida $^{192}$. Seu amor, ódio e ciúme já pereceram, e eles nunca mais participarão de tudo o que se faz debaixo do sol" (Ecl 9,5-6).

Os mortos, especialmente, não mais louvam a Deus, não mais esperam em sua fidelidade: "Com efeito, não é Xeol que te louva, nem a morte que te glorifica, pois não esperam em tua fidelidade aqueles que descem à cova" (Is 38,18).

Entendida a morte como acima foi expresso, o Sheol é visto um vasto território abaixo da terra, ao qual se descia ${ }^{193}$ com a morte e do qual não era possível haver qualquer retorno: "Como a nuvem se dissipa e desaparece, assim quem desce ao Xeol não subirá jamais” (Jó 7,9).

191 Os mortos são designados no Antigo Testamento, pela palavra r.phaim 'Refaim'. Não é fácil determinar de modo preciso o sentido desta palavra, afinal parece ter havido no decorrer dos séculos múltiplas acepções. Assim, é utilizado para designar, por sua vez, os habitantes do mundo subterrâneo e a população de gigantes que habitou em outro tempo a debilidade dos mortos e o poder de um povo pré-histórico. MARTIN-ACHARD, R., Da morte à Ressurreição segundo o Antigo Testamento, 2005, p. 51.

${ }^{192}$ Sua memória foi esquecida: Qohélet faz um jogo de palavras evidente entre skr (recompensa) e zkr (memória, recordação). No entanto, não tem nada de jogo o sentido das palavras. Algo já se disse da memória e do esquecimento como sobrevivência ou aniquilamento dos mortos conforme a mentalidade de Qohélet (cf. 2,16 e 7,1); mas é aqui em 9,5b que aparece com mais clareza o que é para ele a memória da pessoa desaparecida. A memória que têm os vivos dos que morreram é seu único meio de subsistência. Mantém um defunto seu nome, sua existência se bem que enfraquecida, à medida que é recordado. Como o tempo gera o esquecimento (cf. 2,16), os mortos vão perdendo sua pobre existência debilitada. Quando são de todo esquecidos, morrem definitivamente, ou seja, perdem toda a existência que possuem. LÍNDEZ, J. V., Eclesiastes ou Qohélet, 1999, p. 355.

${ }^{193} \mathrm{Gn} 37,35$, Todos os seus filhos e filhas vieram para consolá-lo, mas ele recusou toda consolação e disse: 'Não é em luto que descerei ao Xeol para junto do meu filho.' E seu pai o chorou." Gn 42,38 "Mas ele retrucou: 'Meu filho não descerá convosco: seu irmão morreu e ele ficou só. Se lhe suceder desgraça na viagem que ireis fazer, na aflição faríeis descer minhas cãs ao Xeol." Gn 44,29.31 "Se tirardes ainda este de junto de mim, e lhe suceder alguma desgraça, na aflição terão feito descer minhas cãs ao Xeol; logo que vir que o rapaz não está conosco ele morrerá, e teu servo na aflição terão feito descer ao Xeol as cãs de teu servo, nosso pai. 
Tal concepção, todavia, pode não ser incompatível como a anterior ${ }^{194}$, e podemos, até mesmo, questionar se a descrição da miserável existência do morto no Sheol não seja apenas um modo simbólico de afirmar o retorno ao nada ${ }^{195}$.

A ideia, porém, de uma região dos mortos, sombria e, situada abaixo da terra, não era exclusiva dos hebreus, mas estava presente em muitos outros povos da antiguidade $^{196}$. No mito acádico da descida da deusa Isthar ao mundo dos mortos, este é descrito como "a casa escura, a morada de Irkalla, a terra de onde não há retorno, da qual não há caminho para voltar, onde os que entram são privados de luz, onde o pó é a sua comida e a lama a sua alimentação, onde eles não vêem a luz, onde sobre o ferrolho e a porta se espalha pó"197. O nome Irkalla, que designava originalmente a deusa babilônica dos mortos, passou depois a significar o próprio mundo inferior.

As contradições presentes no Antigo Testamento, em relação ao conceito de morte e morada dos mortos, se agravam ainda mais com as influências dos demais povos do médio Oriente, com os quais conviviam os israelitas. Convivendo com nações que acreditavam no poder dos mortos, Israel não podia deixar de temê-los, ou, até mesmo, invocá-los. Demonstra-o os ritos funerários, nos quais, ao mesmo tempo em que rendiam honras aos mortos, se evitava todo contato com eles, impedindo-os de qualquer possibilidade de retorno ao mundo dos vivos. Se, em alguns casos, os ritos funerários significavam apenas uma humilde compaixão para com os mortos, em outros eram expressão de um temor ou repúdio, tendo como objetivo de impedir que o poder dos mortos se expandisse e contaminasse o grupo familiar, ou até mesmo a nação inteira: "O essencial era o tratamento dado ao cadáver. Os parentes fechavam-

\footnotetext{
194 O Sheol está constituído por uma série de túmulos gigantes. As sepulturas individuais são apenas uma manifestação particular. Para um israelita não se cogita o problema de saber se o morto reside no sepulcro ou no império dos mortos. Aquele (das Grab) é uma expressão deste (das Urgrab). MARTINACHARD, R., Da morte à Ressurreição segundo o Antigo Testamento, 2005 p. 55,

195. MARCHADOUR, A. Morte e Vida na Bíblia, 2001, p. 12.

196 O mundo dos mortos, o Sheol dos hebreus, é totalmente comparável ao Hades dos gregos, e ao Aralu dos assírios babilônicos. Alguns pesquisadores são de opinião de que os israelitas tomaram esta noção de um reino de espíritos de seus vizinhos, mas se esta hipótese for verdadeira, o empréstimo é muito antigo e data provavelmente antes da entrada dos hebreus na Palestina. MARTIN-ACHARD, R., Da morte à Ressurreição segundo o Antigo Testamento, 2005, p. 54.

${ }^{197}$ MACKENZIE, J.L., Dicionário Bíblico, 1983, p. 972.
} 
lhe os olhos e a boca, sem dúvida para impedir que o espírito do morto escapasse e saísse indo se refugiar em algum utensílio mal fechado (Nm 19.14,15)"198.

Se alguns textos indicam que os mortos eram imaginados como fracos e inativos (refains), em outros aparecem dotados de uma ciência superior e de um poder quase divino, sendo, por isso, chamados "elohim", espíritos divinos. Na famosa cena em que Saul, a quem Iahweh não respondia "nem por sonho, nem pela sorte, nem pelos profetas" (1Sm 28,6) resolve recorrer à consulta dos mortos, a necromante de En-Dor, após invocar Samuel, vê um elohim que subia da terra, o qual revelou ao rei seu fim iminente ${ }^{199}$. Entendia-se, pois, que

os mortos, ou pelo menos alguns deles, estão dotados de um poder que escapa aos humanos, conhecem o futuro. A esta tradição faz menção, sem dúvida, Isaías quando convida ironicamente seus contemporâneos infiéis a invocar os seus deuses (isto é, seus mortos), uma vez que recusam crer em Yahweh" ${ }^{200}$ : "Perguntai aos que evocam os mortos, aos adivinhos, aos que cochicham e sussurram - acaso um povo não consulta seus deuses, os mortos em favor dos vivos? (Is 8,19).

Por isso, se em algumas passagens se afirma uma completa igualdade entre todos os que descem ao Sheol ("lá pequenos e grandes se avizinham, o escravo livrase de seu amo", Jó 3,19), outras parecem supor uma hierarquização entre as sombras: "Nas profundezas, o Xeol se agita por causa de ti, para vir ao teu encontro; para receber-te despertou os mortos, todos os potentados da terra, fez erguerem-se dos seus tronos os reis das nações" (Is 14,9; notar, porém, o caráter satírico do texto, uma

198 MARTIN-ACHARD, R., Da morte à Ressurreição segundo o Antigo Testamento, 2005 p. 45.

199 "E a mulher respondeu a Saul: 'Vejo um deus que sobe da terra"” (1Sm 28,13).

${ }^{200}$ Ibid. p. 51. H.W.Wolff comenta o texto a propósito da profunda desmistificação da morte realizada no Antigo Testamento: O Antigo Testamento até relata um bem-sucedido esconjuro de mortos, o qual, porém, precisamente como 'bem-sucedido', mostra de modo óbvio o absurdo da empresa. Faz parte da insânia do rei Saul que, disfarçado, peca, contrariando sua própria proibição (1Sm 28.3), à esconjuradora de mortos de En-Dor a evocação de Samuel morto, pois o silêncio de Deus em face da ameaça dos filisteus o deixou completamente desnorteado (1Sm 28.4ss). De fato, Samuel surge como um fantasma. Mas que diz? Repreende a perturbação de seu descanso e recorda aquilo que tinha anunciado antes a Saul: que Javé tinha se afastado dele e dado a realeza a Davi (vv. 15ss). Assim, essa narrativa de uma evocação dos mortos, singular no Antigo Testamento, mostra que dos espíritos dos mortos não se pode esperar nada que ultrapasse aquilo que os mensageiros vivos atestam. WOLFF, H. W., Antropologia do Antigo Testamento, 2007, pp. 168-169. Porém, há de se notar que nas palavras do espírito de Samuel, há uma informação nova, referente ao futuro não conhecido por Saul: Amanhã, tu e teus filhos estareis comigo, e o exército de Israel também (1Sm 27,19). 
sátira contra o rei da Babilônia) ${ }^{201}$. A representação da morada dos mortos, organizada como uma cidade se encontra também, muitas vezes, na literatura rabínica ${ }^{202}$.

Nos períodos mais antigos a distinção estabelecida entre os mortos não provinha de quaisquer considerações morais, mas dependia da situação social do morto ou do cuidado prestado a seu cadáver ${ }^{203}$. Evoluindo a doutrina da retribuição, principalmente no período intertestamentário, e, mais ainda, quando a noção da imortalidade da alma foi introduzida no pensamento judaico ${ }^{204}$, ocorre nova mudança na compreensão da morte, que, necessariamente, deveria refletir na compreensão da morada dos mortos.

O Sheol aparece, então, como um lugar apenas para os ímpios, às vezes identificado com a geena ${ }^{205}$. Distante deste lugar de castigo, ficava o Paraíso, onde, após a morte eram levados os justos. Tal concepção é particularmente presente em apócrifos, tais como a Assunção de Moisés e o Primeiro livro de Enoque ${ }^{206}$.

\footnotetext{
201 Mas esta concepção de um nivelamento por baixo, se opõe a uma tradição que parece ser mais antiga, na qual cada um conserva sua classe social e, além do mais, permanecendo as hierarquias, onde a uniformidade da morte não exclui claras distinções entre os mortos, nem ao menos entre as sombras do Sheol MARTIN-ACHARD, R., Da morte à Ressurreição segundo o Antigo Testamento, 2005, p. 56.

202 VAN DER BORN, A.(Org).Dicionário Enciclopédico da Bíblia, 1971, pp. 659-660.

${ }^{203}$ MARTIN-ACHARD, R., Da morte à Ressurreição segundo o Antigo Testamento, 2005, p. 56.

204 Tal pode ser atestado no livro mais recente do Antigo Testamento, a Sabedoria: A antropologia grega admitira desde muito cedo um consenso acerca da imortalidade da alma. Com a morte, o corpo prisão ('sôma-sêma') liberta a alma que, então pode gozar da imortalidade. Sem chegar a dizer que o autor da Sabedoria adota as categorias da filosofia grega, pode-se admitir que ele assimila 'uma crença comum separada dos seus pressupostos e provas filosóficos'. /.../ em contato com a filosofia grega, o obstáculo antropológico levanta-se: a alma 'que se apresenta mais destacada da matéria, muito menos imersa no corpo que o 'nefesh' sobrevive, dotada de uma existência autônoma, muito mais real do que 'as sombras' que conheciam os Judeus. MARCHADOUR, A. Morte e Vida na Bíblia, 2001, p. 36.

${ }^{205}$ Geena (gr.) representa o aramaico gehinnam que por sua vez representa o hebraico gehinnom. Geena é uma abreviatura do título 'vale do filho de Enom'. Geena é um termo geográfico que divide a antiga Jerusalém das colinas do sul e do oeste. $\mathrm{O}$ vale era um ponto limítrofe entre Judá e Benjamim. Js 15,8; 18,16; Ne 11,30. O vale tinha reputação má nos últimos livros do Antigo Testamento, porque era a região do Tofet, um santuário cúltico onde eram oferecidos sacrifícios humanos. $2 \mathrm{Rs} 23,10 ; 2 \mathrm{Cr}$ 28,$3 ; 33,6 \mathrm{Jr} 7,31 ; 19,2 \mathrm{ss} ; 32,35$. Jeremias amaldiçoou o local devido ao culto e previu que o lugar seria de morte e de corrupção 7,32; 19,6ss. No Novo Testamento Geena era compreendida como punição e prisão Mt 5,25-26, desgraça Mt 8,12; 13,42.50; 22,13; 24,51, corrupção interminável Mc 9,48 tirado de Is 66,24 ou lugar de escuridão Mt 8,12; 22,13; 25,30. MACKENZIE, J.L., Dicionário Bíblico, 1983, pp. 376-377.

${ }^{206}$ E Deus te exaltará, e o fará se aproximar do céu e das estrelas, no lugar da sua habitação. E tu olharás do alto e verá seus inimigos no Geena e os reconhecerá e se alegrará e dará graças e confessará
} 
Por fim, deve-se notar a progressiva personificação do Sheol no Antigo Testamento. Essa personificação, já presente em Is 14,9 (onde o Sheol se agita e desperta os que morreram), aumentou até fazer do Sheol um monstro devorador insaciável: "Por isso o Xeol alarga sua goela, sua boca se abre desmesuradamente" (Is 5,14). "O Sheol não é somente uma região distante que espera passivamente que os humanos morram um após outro; na verdade é uma potência que não pestaneja ao ameaçar os vivos, um mostro insaciável que abre sua boca para devorar Israel"207.

\subsection{2 - Descer e subir da morada dos mortos.}

Em algumas passagens do antigo Testamento parecem entender o Sheol como além de qualquer intervenção, inclusive a divina. $\mathrm{O}$ mundo dos mortos, com efeito, está no sentido oposto do céu, o ponto mais baixo do universo, nas profundezas do abismo (S1 63,10), o mais longe possível do lugar de onde reina Iahweh (Jó 11,8). Os mortos estariam além da lembrança e da atuação do Senhor: "despedido entre os mortos, como as vítimas que jazem nos sepulcros, das quais já não lembras porque foram separadas de tua mão" (S1 88,6). Esquecidos pelo Senhor, os mortos também dele não mais se lembram, ficando Iahweh privado de seus louvores: "Realizas maravilhas pelos mortos? As sombras se levantam para te louvar? Falam do teu amor nas sepulturas, da tua fidelidade no lugar da perdição? Conhecem tuas maravilhas na treva, e tua justiça na terra do esquecimento?" (S1 88,11-13). Quando se dizia ser "Iahweh quem faz morrer e viver, faz descer ao Xeol e dele subir" (1Sm 2,6), tal significava apenas a cura de uma doença grave, pois "quem desce ao Xeol, não subirá jamais" (Jó 7,9).

ao teu Criador. (ASSUNÇÃO DE MOISÉS 10. In: Apócrifos da Bíblia e pseudo-epígrafos, 2005, p. 195). Respondeu-me então Uriel, um dos santos Anjos que estavam comigo, e disse: "Aquela garganta maldita que viste foi destinada aos eternamente malditos; alí serão reagrupados todos aqueles que, com a sua boca, proferem coisas desrespeitosas contra Deus e falam com insolência da sua Glória. Ali eles serão reunidos; será o lugar do seu Julgamento. (Idem. LIVRO DE ENOQUE 27,2, p. 273. Eu olhei e voltei-me para outra parte da terra. Lá eu vi um vale profundo, onde havia fogo com labaredas. E eles traziam os reis e os poderosos e arremessavam-nos naquele vale profundo. (Ibid. 54,1).

${ }^{207}$ MARTIN-ACHARD, R., Da morte à Ressurreição segundo o Antigo Testamento, 2005, p. 59. 
Por outro lado, o Antigo Testamento rejeita toda forma de dualismo, nunca aceitando uma luta de opostos, entre divindades de igual poder. Não põe dúvidas ou limites ao poder de Iahweh: o Deus vivo pode intervir no Sheol. Assim o profeta Amós, falando em nome do Senhor, ameaça aos israelitas pecadores: "Nenhum deles poderá fugir, nenhum deles poderá escapar! Se penetrarem no Xeol, lá minha mão os prenderá” (Am 9,1c-2) e Isaías, também falando em nome do Senhor, pode oferecer a Acaz um sinal "nas profundezas do Xeol, ou nas alturas" (Is 7,11). Também o salmista iria afirmar: "Se subo aos céus, tu lá estás; se me deito no Xeol, aí te encontro" (S1 139,8; também S1 135,6 onde “abismo" significa a mansão dos mortos e $\operatorname{Pr} 15,11)$.

A consciência de que Iahweh possuía um poder ilimitado, inclusive sobre a morada dos mortos, possibilitou o surgimento da doutrina da ressurreição. Iahweh pode não apenas fazer o homem descer à mansão os mortos, mas, também, tirá-lo de lá. Os textos de 1Rs 17,17-23; 2Rs 4,33-35; 13,21 mostram a ressurreição de um morto como algo possível; a passagem de Sb 16,13: "Porque tu tens poder sobre a vida e a morte, fazes descer às portas do Hades e de lá subir" (praticamente idêntico ao já citado texto de $1 \mathrm{Sm}$ 2,6) deve ser entendida como referência a ressurreição, em sentido estrito.

A doutrina da ressurreição teve um aparecimento bastante tardio no pensamento vétero-testamentário: "quando, pela primeira vez, um crente afirma a sua fé na Ressurreição dos mortos, há mais de 1600 anos que os patriarcas ouviram a chamada de Deus, mais de um milênio que Moisés encontrou o Deus surpreendente do Sinai. Duzentos anos mais tarde dar-se-à o início da pregação de Jesus" ${ }^{208}$. O autor citado refere-se ao texto de Dn 12,1-2, considerado como uma das revelações mais importantes do Antigo Testamento: "E muitos dos que dormem no solo poeirento acordarão, uns para a vida eterna e outros para o opróbrio, para o horror eterno".

O texto de Daniel não usa, porém, a palavra "ressurreição", que aparecerá pela primeira vez nas Escrituras nos lábios de um dos irmãos Macabeus: “Chegado já o

\footnotetext{
${ }^{208}$ MARCHADOUR, A. Morte e Vida na Bíblia, 2001, p. 35.
} 
último alento, disse: 'Tu, celerado, nos tiras desta vida presente. Mas, o Rei do mundo nos fará ressuscitar para uma vida eterna, a nós que morremos por suas leis!" $(2 \mathrm{Mc} 7,9)$.

Foi à consciência da fidelidade de Deus, que não abandona seus fiéis, que fez florescer essa doutrina. Se o sonho do israelita era morrer "velho e saciado de dias" (Gn 35,29), rodeado de filhos (Sl 128,3), a dramática situação de perseguição e martírio, fez com que a ressurreição fosse percebida como uma consequência necessária da justiça e fidelidade divina (2Mc 7,9: “Chegado já ao último alento, disse: 'Tu celerado, nos tira desta vida presente, mas, o Rei do mundo nos fará ressuscitar para uma vida eterna, a nós que morremos por suas leis!’), despertando a fé na ação de Deus todo poderoso, que arrebatará os seus mártires da morada dos mortos, para lhes dar uma recompensa que não mais se acabará 209 .

No que se refere à possibilidade de alguém ir e voltar da morada dos mortos, merece atenção o livro apócrifo de Enoque. Este consiste em uma série de cinco documentos, de datação diferente, que tratam do personagem enigmático do Antigo Testamento, que andou com Deus e foi por Ele arrebatado (Gn 5,18; Eclo 44,16). Estes documentos, que os Padres conheceram separados, foram reunidos em um só livro, conservados em etíope.

O livro exerceu influência no Novo Testamento, particularmente nas epístolas católicas: Jd 14-15 que é uma citação (provavelmente de memória) de Enoque. 60,5;

${ }^{209}$ Outras culturas podem supor uma influência decisiva na evolução da compreensão da ressurreição no Antigo Testamento. Israel conhecia o mito sobre um deus (Baal) cuja descida à mansão dos mortos e consequentemente a ressurreição era celebrada no culto como uma personificação da natureza (Jr 17,10; Ez 8,14; Zac 12,11; Os 6,1). Os persas também poderiam ter influenciado a fé judaica na compreensão da ressurreição, porém tem algumas diferenças importantes: a ressurreição para os persas era universal enquanto que para o judaísmo era limitado a determinadas categorias de pessoas; para os persas a ressurreição para aqueles que cometiam atos maus era sinal de purificação, para o judaísmo o castigo permanece eterno para os maus, mesmo se ressuscitarem. Apesar das contradições a respeito da ressurreição é possível que Israel tenha tido um contato com as ideias persas, ocasionando uma influência fecunda, uma evolução de uma doutrina sobre a ressurreição na fé judaica. VAN DER BORN, A.(Org).Dicionário Enciclopédico da Bíblia, 1971, pp. 1303-1304. 
a ele também se refere (provavelmente) o texto de 2Pd 2,4; a relação de Enoque com 1Pd 3,18-19 será objeto de um estudo mais pormenorizado que faremos adiante ${ }^{210}$.

O primeiro documento desta coleção, denominado Livro dos Anjos (ou "dos Guardiões”, cap. 1 a 36); é datado entre os séculos III e II a.C e contém uma leitura midráshica de Gn 6,1-4. Narra como alguns anjos maus (os “Guardiões” Azazel, Semjaza, Barakijal, etc) enamoraram-se por mulheres, às quais ensinaram feitiçarias, $(7,1)^{211}$ e delas geraram os gigantes que oprimiram os homens $(7,2)$. Os anjos bons, Miguel, Uriel, Rafael e Gabriel, levaram o clamor dos homens junto ao Altíssimo $(9,1-7)$, que determinou que os Guardiões fossem amarrados e lançados a um buraco, cavado no deserto de Dudael, onde iriam esperar o julgamento final (10,3-4).

No cap. 12 o livro narra o chamado de Enoque para anunciar aos Guardiões caídos à sentença condenatória: "Não encontrareis nem paz nem perdão" $(12,2)$. Como o acesso ao Senhor dos céus lhes estava vetado, eles pediram a Enoque que intercedesse em seu favor. Enoque atendeu o pedido: "eu redigi o seu rogo de súplica, falando da sua condição de espíritos e dos atos individualmente praticados, e contendo o seu pedido especial de clemência e perdão" $(13,4)$. Mas a súplica não foi atendida e a Enoque foi ordenado que voltasse com a terrível resposta: "Vós não tereis nenhuma paz!” $(16,2)$.

210 A obra influenciou também o Testamento dos Doze Patriarcas (apócrifo do período intertestamentário; cf. Testamento de. Rubén 5,2 (TESTAMENTO DE RUBÉN. In: Apócrifos da Bíblia e pseudo-epígrafos. 2005, p 338.), sendo citada no Testamento de. Levi 14,1 (TESTAMENTO DE LEVI. In: Apócrifos da Bíblia e pseudo-epígrafos. 2005, p. 347.) e na II Apologia (4,3-4) de Justino (JUSTINO, II Apologia, 4,3-4, 1995, p. 95 (Coleção Patrística, 3).

211 Narra ainda que corromperam os homens ensinando-lhes a lidar com os metais (confecção de armas; 8,1), bem como esconjuros e poções de feitiços, astrologia (8,2) (LIVRO DE ENOQUE. In: Apócrifos da Bíblia e pseudo-epígrafos, 2005, pp. 261-262). 
No início do séc. XX desenvolveu-se a interpretação de 1Pd 3,18-19 como descida de Cristo à morada dos mortos, baseada numa suposta utilização do Livro de Enoque. Tal interpretação, porém, apresenta problemas. Embora o Livro descreva a visita de Enoque à morada dos mortos (cf. 22; 27,1-3; 54,1), não é certa sequer a identificação do local da prisão dos anjos decaídos, se nas profundezas da terra ${ }^{212}$, ou em um lugar entre o céu e a terra, como afirma de modo enigmático os capítulos 18 e 19. Também não é certo que, o lugar "nos vales da terra" $(10,7)^{213}$ ou o buraco no deserto de Dudael, onde estavam os Guardiões acorrentados, se refira à morada dos mortos.

\subsection{3 - O Hades.}

A etimologia do termo grego Hades (Aı $\left.\delta\rceil \varsigma^{\prime}\right)$ é incerta. "Se se considera a derivação de $\imath \delta \varepsilon \iota$ [ideín] = ver, com 'a' privativo, então significa 'o invisível', mas pode ser também que hades se relacione com $\alpha$ ı $\alpha v \varepsilon \zeta$ [aianes] e então seu sentido originário seria "triste, espanto"" 214. "Hades" designava originalmente o deus olímpico dos mortos, sendo este o sentido que a palavra é usada na Ilíada de Homero $^{215}$. Logo, porém, passou a significar a morada dos mortos, entendida como um lugar subterrâneo e sombrio, habitado pelas sombras.

\footnotetext{
${ }^{212}$ E a Raphael disse o Senhor: 'Amarra Azazel de mãos e pés e lança-o nas trevas! Cava um buraco no deserto de Dudael e atira-o ao fundo! Deposita pedras ásperas e pontiagudas debaixo dele e cobre-o de escuridão! Deixa-o permanecer lá para sempre e veda-lhe o rosto para que não veja a luz! Enoque 10,3 (Id. p. 263).

${ }^{213} \mathrm{Na}$ tradução espanhola de F. CORRIENTE- A. PIÑERO se diz: "bajo los collados de la tierra" (SANTAMARIA LANCHO, J.A., Un estudio sobre la soteriología Del dogma del Descensus ad ínferos: 1 Pe 3,19-20a y la tradición sobre "la Predicación de Cristo en los Infiernos". 2007. p. 58. Tese (Doutorado em Teologia) Fakultät der Ludwig-Maximilians-Universität München, München, 2007).

${ }^{214}$ H. Bietenhard, verbete infierno, in COENEN et alii, Diccionario Teologico del Nuevo Testamento II, 1990, p. 349).

${ }^{215}$ Cf. Ibid., p. 348.
} 
Sendo o Hades comparável ao Sheol dos judeus ${ }^{216}$, dele se pode afirmar muito do que acima foi dito do Sheol, como se pode facilmente perceber em dois textos de Homero:

a) na Ilíada, o fantasma de Pátroclo aparece a Aquiles, pedindo que o sepultasse quanto antes, para que ele pudesse "passar as portas do Hades (Aî́ $\alpha 0$ ), pois as almas ( $\psi v \chi \alpha i)$, que são imagens ( $\varepsilon^{\prime}(\delta \omega \lambda \alpha)$ dos defuntos", o rechaçavam, impedindo-o de atravessar o rio e chegar ao "palácio de amplas portas de Hades" 217. Após tentar inutilmente abraçar o amigo, Aquiles exclama: “Oh deuses! Certo é que

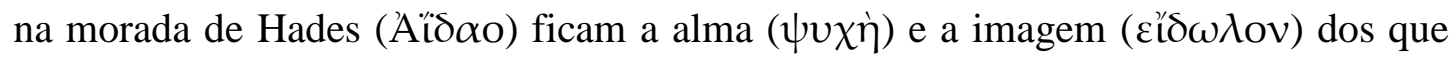

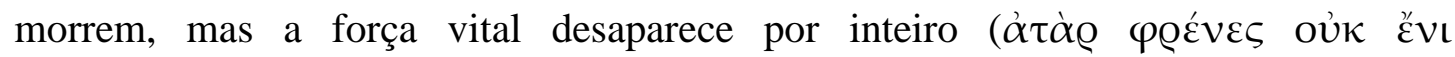
$\pi \alpha ́ \alpha \tau \alpha \nu)^{\prime 218}$.

b) na Odisséia, quando Ulisses (Odisseu) vai consultar falecido adivinho Tirésias, este, antes de lhe dar seus vaticínios, o questiona por ter deixado a luz do sol

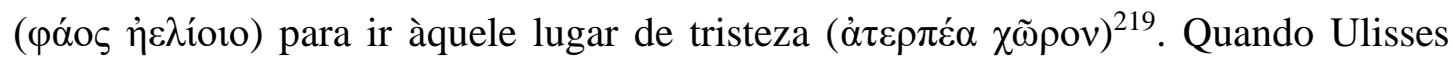
tenta inutilmente abraçar sua falecida mãe, esta se esvai, como sombra ( $\sigma \kappa \imath$ ñ) e sonho (ỏveíp $)^{220}$. Também Aquiles fala com Ulisses, afirmando estarem os mortos

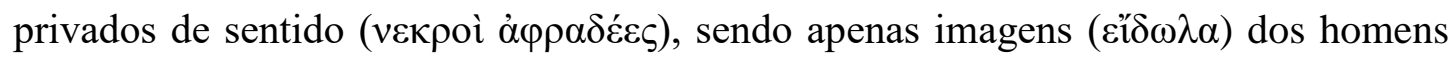
falecidos. Quando Ulisses tenta consolá-lo por sua morte, dizendo-lhe ser venerado como um deus, ele respondeu que preferiria ser lavrador e servir a um homem

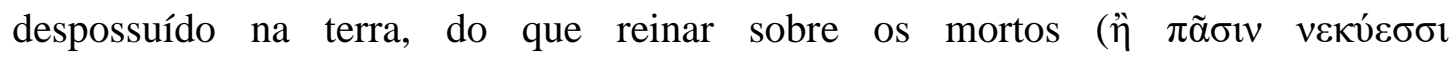

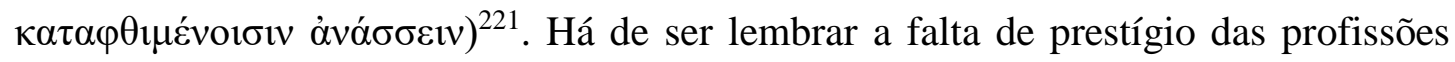
manuais e, mais ainda, da servidão entre os gregos, pelo que a frase expressa bem à situação de desespero do herói.

\footnotetext{
${ }^{216}$ Cf. MARTIN-ACHARD, R., Da morte à Ressurreição segundo o Antigo Testamento, 2005, p. 54.

${ }^{217}$ Ilíada, XXIII, 69. Versão para e-book. e-BooksBrasil.com. Fuente digital

http://abcdioses.noneto.com. Acessado em 04 de Dezembro de 2010.

218 Ibid. Ilíada, XXIII, 103.

${ }^{219}$ Odisséia XI, 94. Versão para e-book. e-BooksBrasil.com. Fuente digital

http://abcdioses.noneto.com. Acessado em 04 de Dezembro de 2010.

${ }^{220}$ Ibid. 207.

${ }^{221}$ Ibid. XI, 492.
} 
Nos textos citados, percebe-se clara semelhança com a ideia do Sheol hebraico, inclusive em suas incoerências: o que sobrou do ser humano após a morte vagueia semi-consciente pela morada dos mortos; o que não impediu um dos mortos, Tirésias, ser capaz de revelar a Ulisses o seu futuro, como fizera o espírito de Samuel a Saul.

\subsection{4 - O Hades no Novo Testamento.}

O termo "Hades" foi utilizado pela Septuaginta para traduzir o hebraico Sheol,

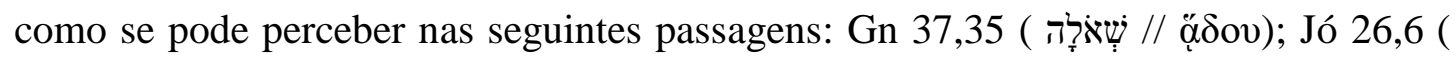

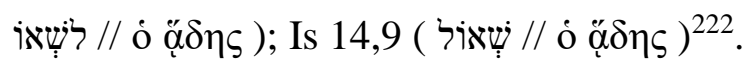

Como sucede com a palavra Sheol vetero-testamentária, as diversas vezes que o termo Hades é usado no Novo Testamento apresentam significados próximos, mas não idênticos. Em Mt 11,23 (// Lc 10,15) refere-se a um lugar subterrâneo, de castigo

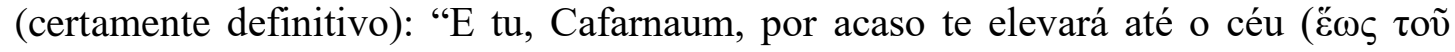

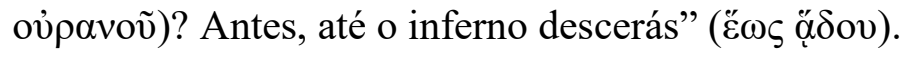

No livro do Apocalipse (talvez, também em At 2,27.31 "porque não abandonarás minha alma no Hades nem permitirás que teu Santo veja a corrupção; previu e anunciou a ressurreição de Cristo, o qual na verdade não foi abandonado no Hades, nem sua carne viu a corrupção”, citação de S1 16,10) o Hades aparece como o lugar intermediário, anterior ao julgamento final, onde são reunidos todos os mortos, bons e maus: "A Morte e o Hades (o ọ̊ $\delta \eta_{\zeta}$ ) entregaram os mortos que neles estavam" (Ap 20,13). Conforme o pensamento da época, já no Hades haveriam repartições

222 ANTIGO TESTAMENTO POLIGLOTA, 2003; “Nos LXX Hades é a tradução do hebraico šse'ol (xeol), o último e definitivo lugar de descanso para todos os mortos" (VAN DER BORN, A.(Org). Dicionário Enciclopédico da Bíblia, 1971, p. 659). 
separadas para os justos e para os pecadores ${ }^{223}$; essa ideia pode estar presente em Lc 16,19-31, onde por "seio de Abraão" se entende o local dos justos no Hades ${ }^{224}$.

Também, o Novo Testamento conhece uma personificação da morada dos mortos. No Apocalipse, a Morte aparece montada em um cavalo esverdeado (cor do cadáver em decomposição, especialmente dos que morrem pela peste), sendo seguida pelos Hades, qual monstro disposto a devorar as vítimas: "Vi aparecer um cavalo esverdeado. Seu montador chama-se 'a Morte' e o Hades acompanhava” (Ap 6,8) 225 . Também no Apocalipse, o Hades recebe o mesmo castigo da Morte: “A Morte e o Hades foram então lançados no lago de fogo. Esta é a segunda morte: o lago de fogo”, "O último inimigo a ser destruído é a morte (Ap 20,14; cf. 1Cor 15,26).

A literatura apócrifa desenvolveu ainda mais a personificação do Hades. Nos "Atos de Pilatos" o Hades aparece conversando com Satanás, repreendendo-o por ter trazido Jesus até ele ${ }^{226}$. Diálogo semelhante, encontramos também no "Evangelho de Bartolomeu":

${ }^{223}$ Livro de Enoque 22; 102,4s; 103 (LIVRO DE ENOQUE. In: Apócrifos da Bíblia e pseudoepígrafos, 2005. pp. 270-271; 327-329.

${ }^{224}$ Comentando a passagem J. Jeremias afirma: v. 22: 'en el seno de Abraham': es la designación del lugar de honor en el banquete celestial a la derecha $(\mathrm{Jn} 13,23)$ del padre de familia, Abrahan. En este lugar de honor, la meta suprema de la esperanza, afirma que Lázaro está a la cabeza de todos los

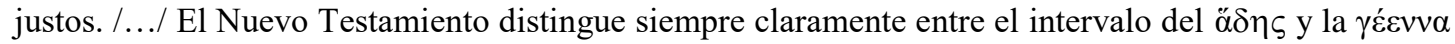
definitiva ('infierno'). Se habla por tanto, de un estado no definitivo. JEREMIAS, J., Las parábolas de Jesús, 1997, pp. 207-208.

${ }^{225}$ Esta personificación del lugar donde residen los muertos va detrás de la peste para devorar a los que perezcan. BROWN, R. E.; FITZMYER, J.A.; MURPHY, R. E.; et al, Comentario Bíblico San Jerónimo, 1972, p. 554.

${ }^{226}$ Respondió el infierno (ó ‘ạ $\delta \eta \varsigma$ ): "Heredero de las tinieblas, hijo de la perdición, calumniador, acabas de decirme que él hacía revivir con una sola palabra a muchos de los que tú tenías preparados para la sepultura; pues, él ha librado a otros del sepulcro, ¿cómo y con qué fuerzas seremos capaces de sujetarle nosotros? Hace poco devoré yo un difunto llamado Lázaro; pero, poco después, uno de los vivos con sola su palabra lo arrancó a viva fuerza de mis entrañas. Y pienso que éste es ese a quién tú te refieres. Si, pues, lo recibimos aquí, tengo miedo de que peligremos también con relación a los demás, porque has de saber que veo agitados a todos los que tengo devorado desde el principio y siento dolores en mi vientre. SANTOS, A. dos, Actas de Pilatos 20, in, Los Evangelios Apócrifos, 2006, p. 441-442. 


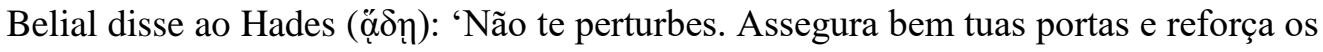

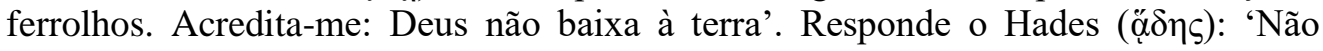
posso ouvir tuas belas palavras. Sinto que se me arrebenta o ventre e minhas entranhas enchem-se de aflição. Outra coisa não pode ser que Deus se apresentou aqui. Ai de mim! ${ }^{227}$

Uma interessante representação do Hades personificado pode ser vista na obra do artista catalão Jaime y Pere Serra (séc. XIV), "Descenso de Jesús al Limbo", no retábulo da Igreja do Convento del Santo Sepulcro de Zaragoça, que pode ser vista na figura $2^{228}$.

\section{2 - A descida de Cristo à morada dos mortos nos primórdios do cristianismo}

Acreditamos que nos primórdios da teologia cristã, a ideia da descida de Cristo a morada dos mortos não tinha outro alcance teológico do que aquele relacionado com a afirmação de sua morte, sendo, praticamente, sinônimo dela. Muitos textos vão insistir na realidade do sepultamento do Senhor, como sinal comprobatório de sua morte. Com efeito, somente com o sepultamento, a morte era considerada completa, consumada ${ }^{229}$.

Desse modo, o kerigma recebido por Paulo, falando da morte, da sepultura e da ressurreição do Senhor, não menciona o Descensus: “eu vos transmiti, antes de tudo, o que eu mesmo tinha recebido, a saber: que Cristo morreu pelos nossos pecados, segundo as Escrituras, foi sepultado e, ao terceiro dia, foi ressuscitado, segundo as Escrituras" (1Cor 15,3-4).

${ }^{227}$ EVANGELIO DE BARTOLOMÉ, I, 18-19 (in Id,p. 539).

228 Cf. Figura 2 p. 285, PITSTICK, A. L., Light in Darkness. Hans Urs von Balthasar and the Catholic Doctrine of Christ's Descent into Hell, 2007, p. 344.

${ }^{229}$ Não deixou o templo de seu corpo aguardar muito tempo, mas comprovada a morte após a luta, logo o ressuscitou, ao terceiro dia, erguendo qual troféu da vitória sobre a morte a incorruptibilidade e impassibilidade obtidas neste corpo. Teria podido, sem dúvida, imediatamente ressuscitar o corpo morto e apresentá-lo vivo, mas o Salvador não o quis, por sábia previdência. No caso de manifestar imediatamente a ressurreição, alguém poderia replicar que não estivera inteiramente morto, ou que a morte não o tocara de modo algum. SANTO ATANÁSIO, A encarnação do Verbo, 26, 1-2, 1995, pp. 160-161 (Coleção Patrística 18. 
Enquanto pudemos observar, não há um texto bíblico do qual se possa dizer com segurança (e sem opositores) que afirme a descida de Cristo à morada dos mortos. Não se pode, porém, afirmar que as Escrituras não conheçam a doutrina. “Tendo em conta as idéias judeu-cristãs sobre o estado da alma após a morte, a cláusula não era senão um corolário natural. Dizer que Jesus Cristo morreu e foi sepultado era o mesmo que afirmar que havia passado ao sheol"230. Algumas passagens bíblicas, porém, são tradicionalmente associadas ao tema do Descensus:

\subsection{1 - Mt 12,40}

Na perícope de Mt 12,40, referente ao sinal de Jonas, encontramos um dos textos que tradicionalmente se associa à doutrina da descida de Cristo à morada dos mortos: "pois como Jonas esteve no ventre do monstro marinho três dias e três noites, assim ficará o Filho do Homem três dias e três noites no seio da terra" (Mt 12,40) ${ }^{231}$.

${ }^{230}$ KELLY, J.N. D.; Primitivos Credos Cristianos, 1980, p. 449.

${ }^{231}$ Dall'analisi del logion in Mt 12,40 sotto l'aspetto storico-redazionale, si ricava già che il segno di Giona è un segno della passion e del descensus del Figlio dell'Uomo. Questa interpretazione viene confortata quando si consideri quella del Midrash di Giona e rispettivamente dei Pirqê di Rabbi Eliezer: la discesa di Giona agl'inferi è qui in posta relazione com la sua vittoria escatológica sul Leviatano, che a sua volta à la personificazione del malvagio, minaccioso maré primigenio del Caos, e questo sta in stretto rapporto com la representazione veterotestamentaria della She'ol. Wilhelm MASS, "Discese all'inferno". Aspetti di un articolo di fede dimenticato, Communio (italiana) 55, 1981, p. 22 
A origem da perícope é controvertida 232 ; menção ao "ventre do monstro marinho" e ao "seio da terra" ausente nos outros Sinóticos, provém do material próprio do evangelista. A frase duplica o sinal: em Mt 12,41 (// Lc 11,32), é a pregação de Jesus e no v.40, sua morte e ressurreição. "Os três dias" referem-se ao modo como a Igreja primitiva contou o sepultamento de Jesus "segundo o cálculo joânico, desde o dia da preparação para a Páscoa/sábado, o dia da festa e o primeiro dia da semana"233.

“O Filho do Homem, Jesus, estará 'no seio da terra', isto é (provavelmente), no sepulcro; a viagem de Jesus ao inferno, importante para a exegese eclesial, seria algo singular na tradição sinótica, e resulta por isso improvável, sem que se possa excluir" ${ }^{234}$. Há de se notar, com efeito, que há uma menção expressa à morada dos mortos na oração de Jonas (cf. Jn 2,3), a qual, porém, pode também ser entendida como simples sinônimo da sepultura (como acima expusemos).

${ }^{232}$ François Bovon assim apresenta a gênese do texto Lc 11,29-32 paralelo a Mt 12,38-42 que analisamos: Si se quiere intentar una visión genética, diremos lo siguiente. En el origen de las tradiciones doble $(\mathrm{Q})$ y triple (Mc 8,11-12) había un breve apotegma: a la petición de un signo Jesús oponía una firme repulsa (Marcos conservó esta respuesta inicial). Este relato se amplió rápidamente, como atestigua la tradición que se oculta tras la fuente de los logia: la negativa estricta de Jesús se ve sustituida por una negativa matizada por una excepción (el añadido, evidentemente cristiano: 'más que el signo de Jonás'). Como en varias ocasiones, se hizo luego necesario un desarrollo de la tradición, esta vez de tipo exegético; entonces se redactó una sentencia como comentario, que se remonta a los cristianos y no a Jesús. Los autores de esta frase querían explicar la excepción e indicar que el Hijo del hombre sería para esta generación lo que había sido Jonás para los ninivitas: para Q y luego para Lucas, el predicador del arrepentimiento; para Mateo, el héroe que sufrió (Mateo, como ya He dicho, no vacilo en modificar profundamente esta sentencia y, por eso mismo, el comentario). La historia de la tradición es una historia de la interpretación. En el caso de Q, y luego de Lucas, el comentario va en un sentido antropológico (aceptación o rechazo del signo). En el caso de Mateo, en un sentido cristológico (el signo es el destino mismo de Jesús). BOVON, F., El Evangelio según San Lucas II, 2002, pp. 245-246. Ver, porém, opinião diferente de LUZ, U.; El Evangelio según San Mateo II, 2001, p. 370 .

${ }^{233}$ VIVIANO,B.T., Evangelio según Mateo. In: Nuevo Comentario Bíblico San Jerónimo, 2004, p. 103.

${ }^{234}$ LUZ, U., El Evangelio según San Mateo II, 2001, p. 364-367 
A associação das imagens de Jonas no ventre do peixe e de Cristo na morada dos mortos tornou-se comum entre os Padres, como se pode ver em Orígenes ${ }^{235}$, Cirilo de Jerusalém ${ }^{236}$ e Quodvultdeus ${ }^{237}$.

\subsection{2 - Mt 27,51-53.}

Nisso, o véu do Santuário se rasgou em duas partes, de cima a baixo, a terra tremeu e as rochas se fenderam. Abriram-se os túmulos e muitos dos corpos dos santos falecidos ressuscitaram. E, saindo dos túmulos, após a ressurreição de Jesus, entraram na Cidade santa e foram vistos por muitos (Mt 27,51-53).

$\mathrm{Na}$ interpretação destes enigmáticos versículos do evangelho de Mateus alguns autores recorreram à doutrina da descida de Jesus à morada dos mortos. Assim, é possível que Cirilo de Jerusalém tenha feito essa associação em sua IV Catequese ${ }^{238}$; mas o texto mais explícito nós encontramos no apócrifo Atos de Pilatos (ou Evangelho de Nicodemos), onde os ressuscitados, que estava morando em Arimatéia, descrevem com detalhes os fatos ocorridos no Inferno, quando Cristo lá desceu para libertar os falecidos ${ }^{239}$ :

${ }^{235}$ Contudo é possível não desesperar completamente. É possível, com efeito, que se ele se arrepende, o que foi engolido seja vomitado como Jonas. Além disso, a nós todos, penso, a terra já nos tinha antes engolido nas profundezas do inferno; é por isso que nosso Senhor desceu não só até a terra, mas 'até as regiões inferiores da terra', ali nos encontrou engolidos e 'sentados na sombra da morte', e tirando-nos dela, nos prepara um lugar, não sobre a terra, por temor que sejamos engolidos de novo, mas um lugar no reino dos céus. (Homilia sobre o Êxodo VI,6, SCh 321, 186).

${ }^{236}$ Jonas foi jogado ao mar e terminou no ventre do cetáceo; Jesus, ao invés, quis espontaneamente descer onde habitavam o monstro da morte; Ele desceu espontaneamente, para que a morte vomitasse os homens que havia engolido. (Catequese 14,17, PG 33, 846).

${ }^{237}$ Sermo 3, De Symbolo, III.6.9-10 (CCL 60,359), cf. o texto em DHü 15.

${ }^{238}$ São Cirilo de Jerusalém afirmou que Jesus foi sepultado encontramos talvez uma associação de Mt 27,51 ao nosso tema; com efeito, o santo bispo afirmou que Jesus foi sepultado como homem em uma tumba rochosa, "pois, diante dele, as rochas aterrorizadas, se partiram em pedaços, pois ele desceu ao mundo subterrâneo para libertar os justos" (Catequese IV, PG 33, 454).

${ }^{239}$ DESCIDA DE CRISTO AO INFERNO, in: Apócrifos e pseudo-epigráficos da Bíblia, versão grega pp. 551-557, ou - versão latina pp. 559-566. 
Senhores, quando íamos da Galiléia ao Jordão, veio ao nosso encontro uma grande multidão de homens vestidos de branco que haviam morrido já há algum tempo. Dentre eles reconhecemos Karino e Lêucio; /.../ perguntamos-lhes: 'Dizei-nos, irmãos e amigos, que são esta alma e este corpo, e quem são estas pessoas com quem caminhais, e como viveis no corpo, sendo que já faz tempo que morrestes?' Eles responderam: 'Ressuscitamos dos infernos com Cristo e Ele nos tirou-nos de entre os mortos. E saibas que a partir de agora ficam destruídas as portas da morte e das trevas, e as almas dos santos foram tiradas dali e subiram ao céu com Cristo Senhor $\operatorname{nosso}^{240}$.

Também os comentadores da Bíblia de Jerusalém fazem a mesma associação: "Essa ressurreição dos justos do AT é sinal da era escatológica (Is 26,19; Ez 37; Dn 12,2). Libertados do Hades pela morte de Cristo (cf. Mt 16,18) ${ }^{241}$, esperam sua ressurreição para entrar com ele na Cidade santa, isto é, Jerusalém. Temos aqui uma das primeiras expressões da fé na libertação dos mortos, pela descida de Cristo aos infernos (cf. 1Pd 3,19)"242.

A associação, porém, não se mostra consistente. Analisando os "fenômenos especiais" que o Evangelho de Mateus descreve junto à morte de Jesus, Raymond

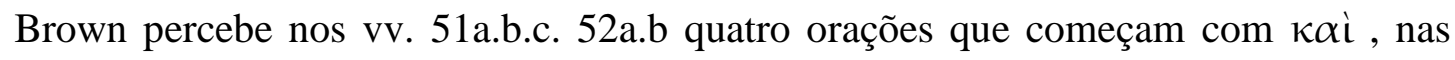
quais são verbos que estão no passivo aoristo ${ }^{243}$, indicadores que o agente é Deus (passivo divino). As frases, pois, devem ser lidas:

\footnotetext{
${ }^{240}$ DESCIDA DE CRISTO AO INFERNO, in: Apócrifos e pseudo-epigráficos da Bíblia versão latina pp. 559.

${ }^{241} \mathrm{O}$ comentador acredita estar relacionado ao Descensus inclusive o texto de Mt 16,18: Aqui, as suas [do Hades] 'portas' personificadas evocam as potências do Mal, que, depois de terem arrastado os homens à morte do pecado, os encadeiam definitivamente na morte eterna. Seguindo o seu Mestre que morreu, 'desceu aos Infernos' (1Pd 3,19) e ressuscitou (At 2,27.31), a Igreja deverá ter por missão arrancar os eleitos ao império da morte temporal e, sobretudo da eterna, para conduzí-los ao reino dos Céus (cf. Cl 1,13; 1Cor 15,26; Ap 6,8; 20,13). (BÍBLIA DE JERUSALÉM, comentário 'a' Mt 16,18). Correto teologicamente, o comentário nos parece questionável do ponto de vista exegético.

${ }^{242}$ BÍBLIA DE JERUSALÉM, comentário 'g' a Mt 27,53.

${ }^{243}$ Cf. v. 51a: $\dot{\varepsilon} \sigma \chi i ́ \sigma \theta \eta$ (foi rasgado), v. 51b: $\dot{\varepsilon} \sigma \chi i ́ \sigma \theta \eta$ (foi sacudida), 51c: $\dot{\varepsilon} \sigma \chi i ́ \sigma \theta \eta \sigma \alpha v$ (foram fendidos,

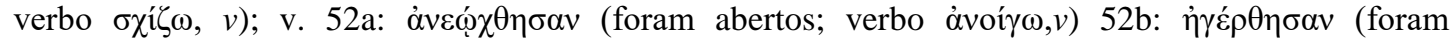

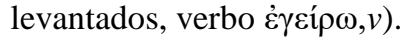


Nisso, Deus rasgou o véu do Santuário em duas partes, de cima a baixo, Deus fez a terra tremer e as rochas se fenderem. Deus abriu os túmulos e ressuscitou muitos dos corpos dos santos falecidos". "Antes se falou da obscuridade sobre toda a terra ao meio-dia e do rasgo do véu. Se acrescentamos estes dois fenômenos aos quatro referidos em 51b-52b, temos em Mateus um total de seis acontecimentos apocalípticos associados à morte de Jesus. Alguns anos depois de Mateus, Inácio (Tral. 9,1) escreverá que Jesus 'foi realmente crucificado e morreu, à vista de todos os que estavam no céu, na terra e abaixo da terra'. Quiçá não seja demasiado imaginativo, portanto, ver em Mt 27,51b-52b uma progressão do sinal original no céu (com resultado da obscuridade) a sinais na terra (rasgadura do véu, sacudida sísmica, fendimentos das rochas) e, logo, a sinais abaixo da terra (abertura dos sepulcros e ressurreição dos mortos). Aqueles que em Mt 27,49 estavam perto da cruz pediram burlosamente um sinal do céu ao referir-se à descida de Elias; agora Deus, que lhes havia negado esse sinal, respondeu ampla e majestosamente, como corresponde ao poder divino ${ }^{244}$.

No contexto do primeiro evangelho, o texto citado não faz, portanto, referência alguma a uma descida de Cristo a morada dos mortos ${ }^{245}$. Também Ulrich Luz, após analisar o texto de Mt 27,51-52 com profundidade, conclui que "o texto somente foi relacionado secundária e ocasionalmente com o artigo de fé da descida de Cristo aos infernos. A passagem nunca foi utilizada como legitimação exegética do referido artigo. Isto vem a excluir claramente que por trás de Mt 27,52s exista uma tradição cristã sobre a descida de Cristo aos infernos" 246 .

\subsection{3 - Rm 10,6-8}

Na carta aos romanos, opondo a justiça que vem da observância da Lei, àquela que provêm da fé, após deixar subentendida a primeira $(\mathrm{Rm} 10,5)$, Paulo apresenta o caráter gratuito e fácil da segunda, através de uma explicação midráxica de Dt 30,1114: “a justiça que provém da fé assim se exprime: Não digas em teu coração: Quem subirá ao céu? Isto é, para fazer descer Cristo, ou: Quem descerá ao abismo? Isto é, para fazer Cristo levantar-se dentre os mortos" (Rm 10,6-8).

O texto foi associado à descida de Cristo aos infernos.

\footnotetext{
${ }^{244}$ BROWN, R., La muerte del Mesías II, Verbo Divino, Estella, 2006, p. 1323.

${ }^{245}$ Ningunas de esas referencias al descenso a los infiernos [1Pd 3,18-19; 4,6; Ef 4,8-10; Rm 10,6-7; Fl 2,9] parece tener nada que ver con la descripción ofrecida en Mt 27,52 sobre tumbas abiertas y a resurrección de los santos que dormían en el momento de la muerte de Jesús. BROWN, op. cit. 1332.

${ }^{246}$ LUZ, U.; El Evangelio según San Mateo IV, 2005, p. 445.
} 
Ainda mais claramente a tipologia de Jonas está subjacente a $\mathrm{Rm} \mathrm{10,7,} \mathrm{onde} \mathrm{Paulo}$ usa uma típica exegese midráshica. Em uma detalhada comparação da interpretação paulina com a paráfrase de Dt 30,11-14 no Targum palestinense (na recensão do Codex Neofiti I, descoberto em 1956) parece que ambos substituem "atravesar o mar" com "cair no abismo" e respectivamente "na profundidade do Grande Mar". O Targum se refere em seguida ao versículo do profeta Jonas enquanto que Paulo, evidentemente à luz desta interpretação do Targum relativo a Jonas, refere-o ao descensus de Cristo: Cristo como o novo Jonas. Assim como Jonas esteve dentro do escuro ventre do peixe na profundeza do abismo, assim Cristo esteve no abismo do reino dos mortos ${ }^{247}$.

Com efeito, na passagem Paulo acomoda o texto, alterando o "além-mar" de

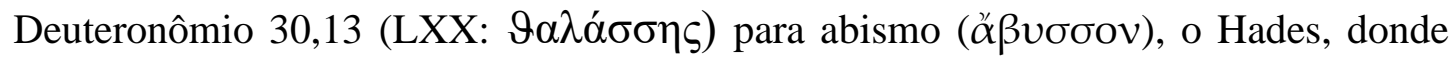
Cristo ressuscitou dos $\operatorname{mortos}^{248}$. A menção fica ainda mais explícita no texto siríaco de $\operatorname{Rm}$ 10,7, “que, onde o grego diz: 'Quem descerá no abismo?', traduz: 'Quem descerá no abismo dos infernos (sheol)?",249

\subsection{4 - Ef 4,8-9}

Citando o Sl 68,19 (“em forma que não corresponde a nenhum manuscrito bíblico hebraico nem grego" ${ }^{250}$ ) o autor da carta aos efésios interpreta-o em relação à ascensão de Jesus e à concessão de dons à Igreja: “Tendo subido às alturas, levou cativo o cativeiro, concedeu dons aos homens. Que significa 'subiu', senão que ele também desceu às profundezas da terra?" (Ef 4,8-9).

Esta passagem de Ef 4,8-9 foi tradicionalmente entendida como se referindo à descida de Cristo à morada dos mortos (cf. Rm 10,7: “ou: Quem descerá ao abismo? Isto é, para fazer Cristo levantar-se dentre os mortos"; Fl 2,10 "a fim de que ao nome de Jesus todo o joelho se dobre nos céus, sobre a terra e debaixo da terra"), mas é bastante provável que se refira à encarnação, pela qual Cristo desceu dos céus a terra. Com efeito, "a cosmologia do autor, segundo a qual todos os seres não humanos

${ }^{247}$ MASS, W., "Discese all'inferno". Aspetti di un articolo di fede dimenticato, Communio (italiana) 55 (1981) p. 22.

${ }^{248}$ A idéia da morada dos mortos associada ao fundo do mar não era estranha ao pensamento veterotestamentário, cf. Jó 38,16-17; Jn 2,3-4.

${ }^{249}$ CHIALÀ, S.; Discese agli inferi, 2000, p. 16.

${ }^{250}$ KOBELSKI, P., Carta a los Efesios. In: Nuevo Comentario Bíblico San Jerónimo, 2004, p. 447. 
benéficos ou malignos, estão situados nas alturas $(1,20-22 ; 3,9-10 ; 6,10-20)$ apóia a interpretação de tēs gēs, 'a terra', como uma aposição em genitivo ('as regiões inferiores', isto é, 'a terra'), e a descida como a encarnação. As regiões inferiores, ta katōtera,

\subsection{5 - At 2,24-31}

Tradicionalmente usado pelos Padres para referir-se à descida de Cristo aos infernos $^{251}$, o sermão kerigmático de Pedro afirma que Deus ressuscitou Jesus, "libertando-o das angústias do Hades, pois não era possível que ele fosse retido em seu poder" (At 2,24).

Em relação ao presente versículo, os manuscritos apresentam divergências. Aqueles comumente chamados de "ocidentais", entre os quais se destaca o Códice Beza (D05, seguido pela Bíblia de Jerusalém, cuja tradução utilizamos), lêem

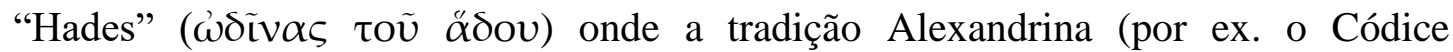

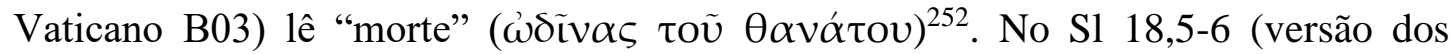
LXX) aparecem as duas expressões, "dores da morte"253 e "dores do Hades" ${ }^{254}$, que, na prática, são equivalentes. A nós, o uso de Hades em At 2,24 parece ser uma harmonização com a citação do Sl 16,10, apresentado a seguir como prova escriturística: "porque não abandonarás minha alma no Hades nem permitirás que teu Santo veja a corrupção" (At 2,27 // S1 16,10) ${ }^{255}$.

${ }^{251}$ Por ex. SANTO AGOSTINHO, Epístola. 164,3 a Evódio (PL 33, 710).

${ }^{252}$ Ambos os textos podem ser encontrados em RIUS-CAMOS, J., READ-HEIMERDINGER, J., $E l$ Mensaje de los Hechos de los Apóstoles en el Códice Beza, 2004, Tomo I, pp. 156, 162. La investigación del s. XX se ha decantado cada vez más a favor del texto 'egipcio' como más cercano al autógrafo de Lucas, principalmente porque el texto 'occidental', más extenso y con omisiones ocasionales, manifiesta tendencias de una revisión consciente DILLON, R. J., Hechos de los Apóstoles, in Nuevo Comentario Bíblico San Jerónimo II, 2004, p. 207.

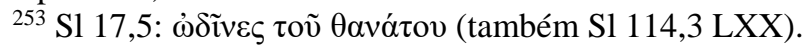

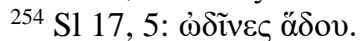

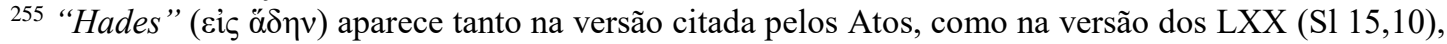
sendo a tradução correta do hebraico Sheol (ש্ৰik S1 16,10). 
“O uso judaico contemporâneo deu a ōdines, 'dores', a conotação de dores messiânicas (Mc 13,8; Mt 24,8; 1Ts 5,3)"256. Porém, conforme W. Haubeck e H. Siebenthal $^{257}$, $\omega \delta \tilde{i} v$ ivos tem o sentido de "dores de parto", pelo qual o texto significaria "algo como: 'que a morte não podia segurar Jesus, assim como uma grávida não pode segurar seu bebê" 258 .

A metáfora que Pedro emprega para descrever a ressurreição é ao mesmo tempo singular e chamativa. A frase 'as terríveis dores da morte' procede da tradução do S1 114,3 LXX e 'as terríveis dores do Sheol (= Hades)' do S1 117,5 LXX, onde em hebreu se lê a palavra ambígua חבל que pude significar 'ataduras' ou 'dores terríveis'. Ainda que a comparação da morte com uma mulher que está dando a luz não seja conhecida nas Escrituras hebraicas, os LXX adotam o último significado, traduzindo o substantivo por $\omega$ $\delta \tilde{v} \varepsilon \varepsilon \varsigma$, que Pedro usa aqui - de fato, mediante uma fusão de idéias, visto que combina 'dores terríveis' com o verbo 'desatar' que sintoniza melhor com a idéia de 'ataduras' -. Ainda que não seja comum a idéia da morte que dá à luz, não obstante, nas Escrituras hebraicas aparece a associação das dores de parto com a redenção de Israel (ver, por ex., Is 66,7; Os 13,13; Jr 13,21; 22,23; $49,24)$ e pode ser esta idéia que suscita a imagem que Pedro utiliza neste ponto. Pedro personifica a morte (especialmente com o nome de Hades em D05, antecipando a referência ao Salmo $15 \mathrm{LXX}$ que está a ponto de citar, At 2,27) como uma mulher parturiente retendo o nascimento de seu filho (cf. Os 13,13) a quem Deus liberta, criando desta maneira uma poderosa imagem da morte que dá à luz à vida $^{259}$.

\subsection{6 - Ap 1,17-18.}

O estudo de Ap 1,17-18 é particularmente importante em relação à interpretação do Descensus como vitória sobre os poderes infernais. Na parte anterior mencionamos a crença vetero-testamentária no poder soberano de Iahweh, que domina inclusive sobre o Sheol (cf. Am 9,1c-2; Is 7,11; Sl 139,8). Em algumas passagens, possivelmente ecos de mitos da criação, Iahweh é apresentado como vencedor de potências do caos, facilmente identificadas como potências infernais:

\footnotetext{
${ }^{256}$ DILLON, R. J., Hechos de los Apóstoles. in: Nuevo Comentário Bíblico San Jerónimo II, 2004, p. 219.

${ }^{257}$ HAUBECK, W.; SIEBENTHAL, H., Nova chave lingüística do Novo Testamento grego, 2009, p. 673.

${ }^{258}$ Idem.

${ }^{259}$ RIUS-CAMPS, J., READ-HEIMERDINGER, J., El Mensaje de los Hechos de los Apóstoles en el Códice Beza, 2004, Tomo I, pp. 175-176.
} 
"Iahweh derrota e mata a monstruosa serpente Leviatã (Is 27,1ss); despedaça Raab e trespassa o Dragão (Is 51,9s); as legiões de Raab devem inclinar-se diante dele (Jó 9,13); Iahweh aniquila Raab e traspassa a Serpente fugitiva (Jó 26,12s); esmaga as cabeças dos monstros das águas e do Leviatã (S1 74,13-15)"260.

Nos evangelhos, em relatos que, com toda probabilidade, remontam ao próprio Jesus histórico, sua ação salvadora é apresentada como uma luta contra as potências do mal. J. Jeremias vê na pequena parábola sobre o combate, transmitida pelos sinóticos (Mc 3,27 // Mt 12,29 e versão independente em Lc 11,21-22), uma peça da tradição pré-pascal, que mostra uma vitória de Jesus sobre Satã, ocorrida antes de seu ministério público (na ocasião da "tentação do deserto") ${ }^{261}$.

Mas, foi principalmente com base em sua crucifixão e ressurreição, que a cristologia das origens cristãs afirmava a vitória de Jesus sobre Satã, como se pode facilmente constatar em passagens como 1Cor 15,24; Cl 2,15; Ef 1,20-21262. Ainda mais explícita é a afirmação do Ressuscitado em Ap 1,17-18: "Eu sou o Primeiro e o Último, o Vivente; estive morto, mais eis que estou vivo pelos séculos dos séculos e tenho as chaves da Morte e dos Hades".

Se Cristo tem agora as chaves, esta posse significa (conforme o Apocalipse está sendo declarado o estado de guerra) o saque de sua vitória, troféu bélico que, em justa batalha, arrebatou a seus donos anteriores; agora Cristo detém de maneira plena o poder, visivelmente representado nas chaves que empunham suas mãos. /.../ Com este triunfo inapelável, pode descer aos infernos, o lugar da morte, abrir suas portas e levar consigo a seus fiéis que se encontravam cativos e aprisionados pelos laços da morte e, não obstante, expectantes e ansiosos de sua vinda. As chaves permitem livre acesso a tais lugares ${ }^{263}$.

${ }^{260}$ MACKENZIE, J. L., Dicionário Bíblico, 1983, p. 198.

261 JEREMIAS, J., Teologia do Novo Testamento, 2004, p.127-128. Ainda, Id. Las parábolas de Jesús, Verbo Divino, Estella, 1997, p. 140: la historia de la tentación en sus diferentes variantes está muy cercana a Mc 3,27; en el mašal de Jesús testimonia a los discípulos la misma experiencia que Mc 3,27 opone a los enemigos: ¡Satán ha sido vencido! ¡Ahora, hoy! ¡Satana maior Christus!.

${ }^{262}$ Idem, Teologia do Novo Testamento, 2004, p.128.

${ }^{263}$ MOLINA, F. C., El Señor de la vida. Lectura Cristológica del Apocalipsis, 1991, p. 61-62. 


\subsection{7 - 1Pd 3,18-20;4,6.}

O texto clássico para se afirmar a descida de Cristo aos infernos e sua pregação aos mortos é 1Pd 3,18-20;4,6. Porém, tal interpretação destes difíceis versículos da Carta do Apóstolo não é isenta de dificuldades, algumas devidas a problemas apresentados pelo próprio texto.

De fato, não é fácil determinar qual a relação de 1Pd 3,18-20 com a sessão parenética anterior, $1 \mathrm{Pd} 3,13-17$, sendo que a interpretação desta afeta a interpretação do texto que segue. Trata-se de uma exortação à conversão dos pagãos, conversão esta que lhes traria a salvação? Nesse caso, os vv. 18-20 deveriam ser lidos como anúncio da generosidade da salvação no Novo Testamento, contrastando com a severidade da Aliança antiga. Ou os vv. 13-17 referem-se à salvação do justo (cristão) e à ameaça de castigo aos injustos, sendo este também o sentido dos versículos que seguem $?^{264}$

Mais ainda, fundamental para a compreensão do texto é saber se a sessão parenética de 1Pd 4,1-6 mantém relação com o texto de 1Pd 3,18-20, como pensa Boismard, sendo esta o fundamento teológico da parenese que segue ${ }^{265}$, ou se os dois textos tratam de assuntos diferentes. Com efeito, ainda que se empreguem os mesmos

\footnotetext{
${ }^{264}$ La doctrine paléochrétienne de la descente reste - du point de vue sotériologique - dans le cadre esquissé par 1 Pierre, mais elle place cet événement très clairement dans les « régions inferieurs de la terre ». Les divers motifs de la descente sont largement développés, et cela de trois manières : Le Christ agit apud infernos premièrement par l'annonce du salut (le motif de la prédication) qui doit être signalé comme le plus ancien), deuxièmement par le don du baptême à tous les justes (de l'Ancienne Alliance) (motif du baptême), et troisièmement par l'assujettissement total de l'enfer et des Maîtres des régions inferieurs (motif du combat). Dans les deux premiers motifs on trouve l'expression du fait que le salut s'acquiert seulement grâce à la foi et le sacrement du baptême (voir 1 Co 15,29) : le baptême vicaire pour les morts). Les justes de l'Ancienne Alliance ne doivent pas être exclus du salut donné par le Christ. Ce Fait entraîne l'annonce de la Bonne Nouvelle du salut et l'administration du baptême au shéol. La doctrine de la descente devient ainsi l'expression de l'universalité de la mission du Christ, qui s'étend jusqu'au commencement de l'humanité. GRILLMEIER, CARDINAL ALOIS, Le Christ dans la tradition chrétienne. De l'âge apostolique au concile de Chalcédoine (451), LES ÉDITIONS DU CERF, PARIS, 2003, p. 261-262.

265 Tout d'abord, il est certain que l'auteur de l'épître développe la section parénétique en 4,1-6 à partir de éléments qu'il a utilisés en 3,18. C'est visible déjà en 4,1: 'Le Christ ayant donc souffert par la chair...'; après la digression concernant le déluge comme type du baptême chrétien, l'auteur reprend son développement parénétique en rappelant les expressions de 3, 18: "Car le Christ a souffert une fois pour lês péchés... mis à mort par la chair'. Mais c'est visible surtout au v. 6 ; pour s'en convaincre, il suffit de mettre les divers membres de phrase en parallèle. BOISMARD, M.-E., Quatre Hymnes Baptismales dans la première épître de Pierre, 1961, p. 64.
} 
termos em ambos os textos, inclusive com certo paralelismo ${ }^{266}$, em 1Pd 4,6 não se menciona o sujeito da pregação, pelo que, se pode interrogar se ambas as passagens tratam de um mesmo acontecimento ${ }^{267}$.

Também não são poucas as dificuldades para tradução do texto de 1 Pd 3,1820, como se pode facilmente observar com a comparação de algumas das versões brasileiras das Sagradas Escrituras (às quais acrescentamos a tradução latina da Nova Vulgata), que colocamos em quadros sinóticos.

266 Além do tema da "pregação" (que aparece em 3,19 e 4,6), o binômio "carne-espírito" (que aparece tanto em 3,18 como em 4,6).

${ }^{267}$ BROWN R., Introdução ao Novo Testamento, 2004, pp. 931-932; On trouve probablement une conception typiquement judéo-chrétienne de cet événement dans 1 P 3, 18-20 avec 4,6. Dans les deux passages, il s'agit vraisemblablement du même événement. Nous y entendons parler d'une venue du Christ. Il n'est pas nécessaire qu'il soit mort en tant que tel, mais on peut présumer la mort et également inclure la Résurrection et l'ascension au ciel. Celui que descend dans la mort et au shéol, ou qui est déjà ressuscité et monte maintenant au ciel, va vers un lieu où des puissances spirituelles, ou peut-être aussi avec elles des âmes humaine, sont gardés. Ce lieu peut être situé en bas (shéol) ou en haut. GRILLMEIER, CARDINAL ALOIS, Le Christ dans la tradition chrétienne. De l'âge apostolique au concile de Chalcédoine (451), LES ÉDITIONS DU CERF, PARIS, 2003, p. 261-262. 


\section{Bíblia Jerusalém ${ }^{268}$}

${ }^{18} \mathrm{Com} \quad$ efeito,

também Cristo morreu uma

vez pelos pecados, o justo

pelos injustos, a fim de vos

conduzir a Deus. Morto na

carne, foi vivificado no

espírito $^{269}$,

${ }^{19}$ no qual foi também

pregar aos espíritos em

prisão,

20 a saber, aos que

foram incrédulos outrora, nos dias de Noé, quando

Deus,

em

sua

longanimidade,

contemporizava com eles,

enquanto Noé construía a

arca, na qual poucas

pessoas, isto é, oito, foram

salvas por meio da água.
Bíblia do Peregrino ${ }^{270}$

\section{Bíblia Tradução}

Ecumênica $^{271}$

${ }^{18}$ Porque Cristo

morreu uma vez por

nossos pecados, o justo

pelos injustos, para vos

conduzir a Deus: sofreu a

morte no corpo,

ressuscitou pelo Espírito

${ }^{19} \mathrm{e}$ assim foi

proclamar também para

as almas encarceradas:

${ }^{20}$ para aqueles que outrora não acreditavam, quando a paciência de Deus contemporizava e Noé fabricava a arca, na qual poucos - oito pessoas - se salvaram atravessando a água. $\begin{array}{cc}{ }^{18} \text { Com } & \text { efeito, } \\ \text { também Cristo morreu }\end{array}$ pelos pecados, uma vez por todas, ele, o justo pelos injustos, a fim de vos apresentar a Deus; ele, justificado em sua carne, mas restituído à vida segundo o Espírito ${ }^{272}$.

${ }^{19}$ Então é que ele foi pregar até aos espíritos que se encontravam na prisão, $\begin{array}{lll}{ }^{20} \text { aos } & \text { rebeldes } & \text { de } \\ \text { outrora, } & \text { quando } & \text { se }\end{array}$ prolongava a paciência de Deus nos dias em que Noé construía a arca, na qual, poucos, isto é, oito pessoas foram salvos pela água.

\begin{tabular}{|c|}
\hline Bíblia de Jerusalém. \\
\hline Edição que \\
\hline preferencialmente em nosso \\
\hline $\begin{array}{l}\text { estudo, Paulus, nova edição } \\
\text { revista e ampliada, } 2004\end{array}$ \\
\hline (conforme a edição francesa \\
\hline $\begin{array}{l}\text { de 1998, La Bible de } \\
\text { Jerusalém, Paris, CERF). }\end{array}$ \\
\hline $\begin{array}{l}{ }^{669} \mathrm{Na} \text { edição francesa de "il a } \\
\text { été vivifié selon l'esprit". }\end{array}$ \\
\hline
\end{tabular}

${ }^{271}$ Bíblia Tradução

Ecumênica, São Paulo:

Edições Loyola, 1994

(traduzido da francês La Bible

- Traduction ocuménique de la Bible, Paris, CERF, 1988).

${ }^{272}$ Em francês: "mais rendu à la vie par l'Esprit". Em nota de rodapé, apresenta como interpretação menos provável: "en cet Esprit", 


\section{Bíblia CNBB ${ }^{273}$}

${ }^{18}$ De fato, também Cristo morreu, uma vez por todas, por causa dos pecados, o justo pelos injustos, a fim de nos conduzir a Deus. Sofreu a morte, na existência humana, mas recebeu nova vida no Espírito.

${ }^{19}$ No Espírito, ele foi também pregar aos espíritos na prisão,

- como nos dias em que Noé construía a arca. Nesta arca, umas poucas pessoas oito - foram salvas, por meio da água.
Nova Vulgata ${ }^{274}$

18 Quia et Christus semel pro peccatis passus est, iustus pro iniustis, ut vos adduceret ad Deum, mortificatus quidem carne, vivificatus autem Spiritu:

${ }^{19}$ in quo et his, qui in carcere erant, spiritibus adveniens praedicavit,

${ }^{20}$ qui increduli fuerant aliquando, quando exspectabat Dei patientia in diebus Noe, cum fabricaretur arca, in qua pauci, id est octo animae, salvae factae sunt per aquam.
${ }^{273}$ Bíblia CNBB, São Paulo: CNBB/Canção Nova, 2008.

\footnotetext{
${ }^{274}$ Nova Vulgata, Bibliorum Sacrorum auctoritate Ioannis Pauli PP. II promulgata. Libreria Editrice Vaticana, 1986.
} 
Bíblia tradução João Ferreira Almeida $^{275}$

${ }^{18}$ Porque também Cristo padeceu uma vez pelos pecados, o justo pelos injustos, para levar-nos a Deus; mortificado, na verdade, na carne, mas vivificado pelo Espírito;

${ }^{19}$ No qual também foi, e pregou aos espíritos em prisão;

20 quando Deus aguardava com paciência, enquanto se edificava a arca, na qual poucas pessoas, isto é, apenas oito se salvaram através da água.

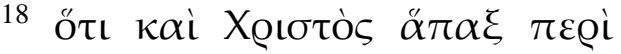

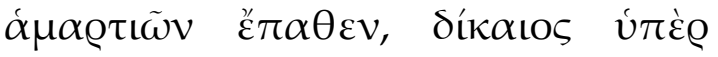

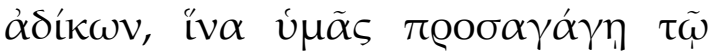

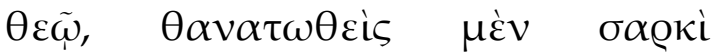

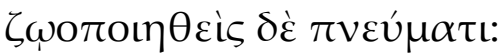

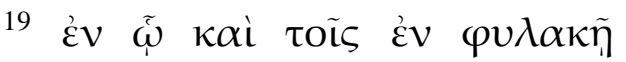

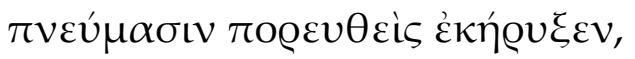

$$
\text { Novo Testamento grego (Nestle) }{ }^{276}
$$

${ }^{275}$ Novo Testamento Interlinear Grego-português. Barueri: Sociedades Bíblicas do Brasil, 2004.

\footnotetext{
${ }^{276}$ Nuevo Testamento Interlineal griego-español, Barcelona: Editorial Clie, 1990.
} 
Algumas diferenças são patentes:

Na expressão $\delta \dot{\varepsilon} \pi \nu \varepsilon v ́ \mu \alpha \tau \iota$ (v. 18) o termo $\pi \nu \varepsilon \tilde{u} \mu \alpha$ pode tanto significar a parte imaterial do ser humano, a alma ou espírito humano (como traduz a Bíblia de Jerusalém), como pode também se referir ao Espírito Santo (como traduzem as demais versões).

O pronome relativo $\dot{\varepsilon} v \tilde{\omega}$ (v.19) é passível de diferentes interpretações. Entendido em relação ao Espírito do v. 18 (como "Espírito Santo”) significaria a participação deste Espírito na pregação de Cristo (Nova Vulgata, Bíblia da CNBB e tradução João Ferreira de Almeida). Entendido como uma expressão grega estereotipada, significando "então é que" (TEB) ou "e assim” (Bíblia do Peregrino), faz o texto dizer que a pregação aconteceu após a Ressurreição. No caso da tradução da Bíblia de Jerusalém, significaria que Cristo foi “espiritualmente" fazer a pregação (“sua alma” foi pregar) ${ }^{277}$.

No v. 19, o advérbio kaì possibilitou as traduções "foi também" ("pregar”, Bíblia de Jerusalém, CNBB; "proclamar”, Bíblia do Peregrino; “e pregou”, João Ferreira de Almeida), assim como a tradução “(foi pregar) até aos" da TEB, o que tem sentido diferente ${ }^{278}$.

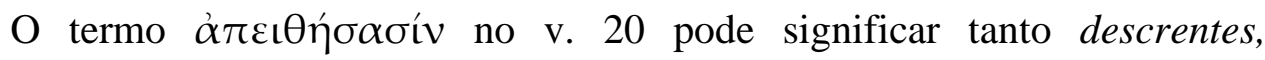
incrédulos, (Nova Vulgata, Bíblia de Jerusalém, Bíblia do Peregrino) como

277 Para exegese, cf. William Joseph DALTON, Christ's proclamation to the spirits. A study of

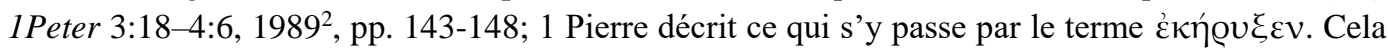
signifie une proclamation ou une manifestation du Christ devant ces puissances ou devant ces âmes; il y voit précisément une proclamation de la divine seigneurie qui a maintenant vaincu toutes les Domination et les Puissances par la mort sur la croix. Partant de la tradition hénochienne, on peut désigner cette proclamation comme une prédication dans l'Hadès. Celle-ci s'adresse aux esprits (ou âmes) qui ont péris dans le déluge - c'est á dire les païens - et se présente comme un modèle de la confession chrétienne. Si l'on considère cette "descente aux enfers" comme une confrontation du Ressuscité, qui remonte avec les puissances spirituelles (ou les âmes) séjournant dans les sphères, il est dès lors facile d'y introduire une interprétation judéo-chrétienne de la descente aux enfers, où le Christ se rend «dans son corps» (sauf si l'on pense à la conception typiquement juive de l'unité du corps et de l'âme). GRILLMEIER, CARDINAL ALOIS, Le Christ dans la tradition chrétienne. De l'âge apostolique au concile de Chalcédoine (451), LES ÉDITIONS DU CERF, PARIS, 2003, p. 261-262.

${ }^{278}$ Ibid. 148-150. 
desobedientes, rebeldes (TEB e CNBB), o que faz bastante diferença na identificação de quem são os “espíritos em prisão" do v. $18^{279}$.

As dificuldades do texto não terminam aí; são deixadas sem resposta (ao menos direta) às outras questões:

Quem são os $\varphi v \lambda \alpha \kappa \tilde{n} \pi v \varepsilon v ́ \mu \alpha \sigma \iota v$ mencionados no v. 19? Seriam os mesmos vek@oĩs mencionados em $1 \mathrm{Pd} 4,6 ?^{280} \mathrm{E}$, nesse caso, a pregação do Senhor teria como destinatários apenas aos justos da antiga Aliança, ou todos os justos falecidos, ou todos os mortos indistintamente? A geração de Noé, explicitamente citada no v. 20, representaria todos os falecidos, ou essa geração seria alvo de uma especial consideração? (e, neste caso, por quê?). Ou, ainda, o termo "espíritos em prisão" não designariam os homens, mas seres das hierarquias celestes decaídos? Conforme Raymond Brown,

na antropologia semítica, a palavra 'espíritos' (distintos de 'fantasmas') é um modo inusitado de referir-se aos mortos; com maior probabilidade, subentenderse-iam os anjos. A referência à desobediência nos dias de Noé sugere que esses são anjos ou filhos de Deus que agiram mal ao manter relações com mulheres na terra, conforme Gn 6,1-4, uma maldade que levou Deus a enviar o grande dilúvio do qual Noé foi salvo (Gn 6,5ss) $)^{281}$.

\footnotetext{
${ }^{279}$ Ibid. 163-164.

${ }^{280}$ Tal é a escolha da Bíblia do Peregrino (ao menos na tradução brasileira, dado que não tivemos acesso ao texto espanhol) ao traduzir por "almas encarceradas".

${ }^{281}$ BROWN, R., Introdução ao Novo Testamento, 2004. pp. 932. Por sua vez, Santamaría Lancho acredita que 1Pd que 3,19-21 trata de la salvación y condena de los hombres. Los desobedientes (identificados en la carta con los paganos (perseguidores) se condenan, y los justos se salvan por el agua. Además, la obediencia esta relacionada en 1 Pe con la escucha y obediencia a la palabra (1 Pe 1, 23-24), que es un tema bautismal. Tampoco hay que olvidar que la tradición conocía una predicación de Noé (cf. 2 Pe) que fue rechazada por sus contemporáneos. (SANTAMARIA LANCHO, J.A., Un estudio sobre la soteriología Del dogma del Descensus ad ínferos: 1 Pe 3,19. 20 a y la tradición sobre "la Predicación de Cristo en los Infiernos". 2007. 200 p. Tese (Doutorado em Teologia) Fakultät der Ludwig-Maximilians-Universität München, München, 2007.p. 134, nota 527).
} 


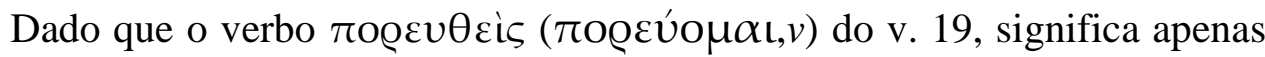
movimento, mudança de lugar, onde estavam estes "espíritos em prisão" aos quais o Senhor foi pregar? Nos abismos da terra (morada dos mortos?), ou nos ares, onde o pensamento bíblico situava os espíritos, inclusive os demoníacos (cf. Ef 2,2$) ?^{282}$

Quando se deu essa pregação? Quando Cristo, conforme a Bíblia de Jerusalém, "morto na carne, vivificado no espírito" foi "espiritualmente" (no espírito) pregar? Ou depois da Ressurreição como traduz a TEB e a Bíblia do Peregrino? Considerando que estes espíritos estivessem "nos ares”, a pregação teria se dado por ocasião de sua Ascensão aos céus?

Qual o conteúdo dessa pregação? Anúncio da salvação, praedicatio evangelica $^{283}$, ou de uma condenação definitiva, praedicatio damnatoria? ${ }^{284}$

Todas essas dificuldades colocam em questão a identificação mesma do texto de 1Pd 3,18-20 com a doutrina da descida de Cristo à morada dos mortos. Esta associação foi feita pela primeira vez por Clemente de Alexandria († 215), sendo que, antes dele, nem mesmo o Evangelho de Pedro a conhecia. Irineu de Lyon nas diversas vezes em que se refere ao Descensus (e mesmo à pregação aos mortos), não o relaciona com o texto da Primeira Carta de Pedro. Mas, introduzida

\footnotetext{
282 Também conforme o pensamento gnóstico, as almas dos mortos subiam pelos ares até o paraíso, sendo interceptada nesse caminho pelos demônios. (DI BERARDINO, A. (Org). Dicionário Patrístico e de Antiguidades Cristãs, 1999, p 1399); Os hereges valentinianos (discípulos do gnóstico Valentin + 160) acreditavam os homens "hílicos" (de alma irracional) e os homens psíquicos de vida irracional desregrada se desfaziam após sua morte, restando apenas os psíquicos de vida racional, divididos em psíquicos não pneumáticos e psíquicos pneumáticos; ¿Donde se congregaban ambos grupos, a raiz de la muerte? Los valentinianos ignoran el Hades subterráneo. Con arreglo a la correlación entre el lugar y sus moradores, parece se congregaban en algunos de los cielos psíquicos dela Hebdómada. Tal vez en el IV cielo planetario (resp. psíquico), o cielo del Paraíso. El mismo cielo, adonde fue levantado el hombre hílico para convivir con el psíquico (cf. Gn 2,8 y 15); y de donde cayó, exiliado por el Demiurgo: recobraría a los dos grupos de 'psíquicos', en espera del Salvador. A raíz de su muerte de Cruz, el Salvador, en vez de bajar al Hades, región subterránea, subió probablemente al IV cielo psíquico, al Paraíso. Allí encontró los dos grupos en estadio aún de ignorancia; en tinieblas del verdadero Dios. (ORBE, A., El 'Descensus ad inferos' y San Irineo, in: Gregorianum, 68, 1987, 489).

${ }^{283}$ Clemente, como veremos adiante, entende a pregação como benéfica, afirmando ter o Senhor "evangelizado aqueles que pereceram no dilúvio" CLEMENTE DE ALEXANDRIA, Les Stromates VI 45,4, 1999, p. 153 (Sources Chrétiennes, 446.

${ }^{284}$ Por isso, diz Damasceno que 'como evangelizou os que estavam na terra, também o fez com os dos infernos', não para converter à fé os incrédulos, mas 'para censurar a infidelidade deles'. (S. Tomás de Aquino, Suma Teológica III,52,2, resp.3. S. Tomás, porém, demonstra crer ser "melhor explicação" a de S. Agostinho, que exporemos adiante). Como autor atual a defender a praedicatio damnatoria encontramos HEIMANN, L.; Pregação aos mortos, 2002.
} 
por Clemente, a associação acabou por se impor, ainda que com interpretações diferentes devido à ambiguidade do texto e aos problemas suscitados pela própria associação.

Pretendendo esclarecer as obscuridades de 1Pd 3,18-20, a partir do séc. XIX, alguns autores ${ }^{285}$ formularam a hipótese de que a passagem estivesse associada ao Livro apócrifo de Enoque, que citamos acima; sendo uma cristianização de um midraxe judaico, que inverteria a obra na qual se inspirou: enquanto Enoque levaria aos espíritos aprisionados a terrível sentença: "Vós não tereis nenhuma paz!” (En. 16,2), o anúncio de Cristo seria a salvação.

A proposta de uma pregação aos anjos caídos relacionado com os espíritos em prisão de $1 \mathrm{Pd} 3,18-20$, agradou a muitos e atualmente parece ter-se tornado dominante na interpretação da passagem ${ }^{286}$. Mas, novamente, trata-se de uma associação que traz problemas! Santamaría Lancho, em sua já citada tese doutoral, aponta diversas dificuldades dessa associação que apresentamos a seguir:

Por diferença de linguagem. Enquanto que nas passagens do Novo Testamento que se referem com segurança ao Livro de Enoque, 2Pd e Jd, são usados os mesmo termos do livro apócrifo ${ }^{287}$, é grande a diferença de termos entre $1 P d$ 3,18-20 e a passagem de Enoque, que tem maior paralelismo com ela no cap. 12, do Livros dos Anjos: "Praticamente nenhuma das palavras usadas no capitulo 12 de 1 Enoque coincide com 1 Pe 3,19"288.

${ }^{285}$ A ideia parece ter sido do teólogo protestante alemão Friedrich Spitta († 1924) (Cf. DALTON, W. J., Christ's proclamation to the Spirits, A study of the 1 Peter 3:18-4:6, 1989, p. 151). Não tivemos acesso à obra de F. Spitta, Christi Predigt an die Geister: 1 Petr. 3, 19 ff. Ein Beitr. zur neutestamentl. Theologie, Göttingen 1890.

${ }^{286}$ Ver JEREMIAS, J., Entre Viernes santo y Domingo de Pascua. In: Abba El mensaje central del Nuevo Testamento, 1999, pp. 189-196, como também BALTHASAR, H. U.; Teología de los tres días, 2000, p. 138; SANTAMARÍA LANCHO (op. cit. 52) indica uma série de autores que seguem essa posição.

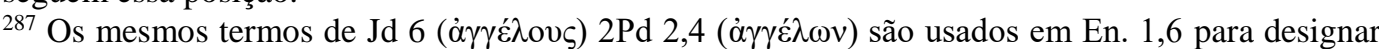
os seres celestiais. Também o termo de Jd 6, $\delta \varepsilon \sigma \mu o \tilde{\varsigma}$ (encarcerados) aparece em 1En. 10,4.12; $10,13.14 ; 13,1 ; 14,5 ; 18,16 ; 21,6$, nunca usando o termo "prisão" citado em 1Pd 3,19. A causa da

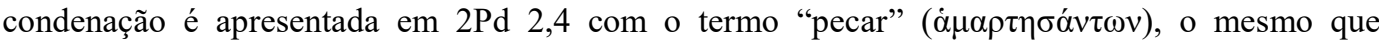
aparece em 1Hen. 6,3;18,16 e 21,6; diferente do termo $\dot{\alpha} \pi \varepsilon 1 \theta \varepsilon \dot{\varepsilon} \omega$ (desobediência, incredulidade)

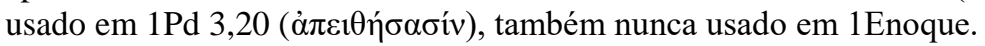

288 SANTAMARIA LANCHO, J.A., Un estudio sobre la soteriología Del dogma del Descensus ad inferos: 1 Pe 3,19-20a y la tradición sobre "la Predicación de Cristo en los Infiernos". 2007. 200 p. Tese (Doutorado em Teologia) Fakultät der Ludwig-Maximilians-Universität München, München, 2007, p. 131. 
Por diferença de temas. No que se refere ao termo $\dot{\alpha} \pi \varepsilon \iota \theta \varepsilon ́ \omega$ (desobediência, incredulidade) usado no v. 20 ( $\dot{\alpha} \pi \varepsilon \iota \theta \eta ́ \sigma \alpha \sigma i ́ v)$, o mesmo aparece na Prima Petri mais três vezes $(2,8 ; 3,1 ; 4,17)$, todas relacionadas à Palavra (ou Evangelho), ou seja, à desobediência à pregação. Ora, não foi esse o pecado que motivou a condenação dos anjos mencionados em Enoque, dos quais se afirma terem mantido relacionamento sexual com mulheres e lhes ensinado artes mágicas.

Também 1Pd 3,20 sugere que a desobediência mencionada se deu "enquanto Noé construía a arca", o que não se pode dizer do pecado dos anjos a que se refere Enoque.

Falta de apoio na tradição. Os Padres da Igreja que conheciam o livro de Enoque, como Justino (II Apologia 5,3-4), nunca o relacionam com o texto da 1Pd 3,18-20.

Concluindo, se deve dizer que, contrariamente a quanto muitos pensaram no passado e alguns continuam a crer hoje, na famosíssima passagem de 1Pd 3,19-20 não se fala da descida de Cristo aos infernos, mas de sua ascensão à glória que é, ao mesmo tempo, salvação e condenação: salvação para todos os que nele creram, a começar pelos justos do Antigo Testamento; condenação contra os incrédulos de todos os tempos, dos quais o modelo mais impressionante oferecem os 'espíritos' malvados que provocaram, segundo a tradição judaica, a devastação do dilúvio 289 .

\footnotetext{
289 Settimio di CIPRIANI, Insegna la prima lettera di Pietro $(3,19-20 ; 4,6)$ la "discesa" di Cristo agli inferi?, in Communio (italiana), 55 [1981] 15. Também William Joseph DALTON, após abundante argumentação, conclui afirmando: To sum up our findings on this fundamentally important phrase of 1Pet 3:18, we may take it as certain that it refers, in stereotyped traditional fashion, to death of Christ and his bodily resurrection, with the emphasis on the resurrection. In no way can it be construed to refer to the 'separated soul' of Christ. If such an idea is introduced into the text, this is due either to a misunderstanding of the antithesis flesh-spirit, or to the subtle pressure of past exegesis which for so long used this text a major evidence for the descent of Christ's soul into the world of the dead. DALTON, W. J.;Christ's proclamation to the spirits. A study of 1Peter 3:18-4:6, 19892 , p. 142.
} 


\section{3 - O desenvolvimento sistemático da descida de Cristo a} morada dos mortos.

Se, conforme pensamos, a ideia da descida de Cristo à morada dos mortos tinha nos primórdios apenas o sentido da afirmação de sua morte (sendo praticamente sinônimo dela), muito cedo, na reflexão patrística a afirmação ganharia novos coloridos, quer cristológicos, quer (e predominantemente) soteriológicos.

Os Padres procuraram, primeiramente, explicar o papel dessa descida na economia da salvação, enfoque que nos parece bastante segundo o pensamento bíblico. São Paulo, com efeito, apresenta, como parte do kerygma, que ele mesmo recebera, não apenas a morte do Senhor, mas também o sentido salvífico desta morte: "morreu por nossos pecados, segundo as Escrituras" (1Cor 15,3), do mesmo modo os Padres explicitaram o sentido soteriológico da descida junto aos mortos. E foi principalmente no âmbito da soteriologia que esta doutrina mais se desenvolveu, quer seja na Patrística, quer seja na reflexão teológica posterior.

Mais tarde, como veremos, foi dada também atenção à questão cristológica, procurando-se analisar o que a afirmação da descida aos infernos significava para a compreensão do próprio mistério de Cristo.

A reflexão dos Padres considerou grandemente nas diferentes profissões que foram progressivamente elaboradas, nas quais se inseriu o artigo que professa a descida de Cristo aos infernos. Nos Símbolos esta foi contemplada, basicamente, sob o enfoque soteriológico.

A teologia dos Padres influenciou, também, as fórmulas litúrgicas onde se menciona a descida de Cristo aos infernos. Ainda que, diversas destas tenham sua formulação definitiva em períodos mais recentes, refletem fundamentalmente, a teologia patrística. 


\subsection{1 - As interpretações soteriológicas}

Duas são as principais imagens com as quais os Padres interpretaram a descida de Cristo aos infernos: a pregação aos mortos e a vitória sobre as potências infernais, imagens que, muitas vezes, se interpenetram e se completam mutuamente.

\subsection{2 - A pregação de Cristo aos mortos.}

Cristo, portanto, desceu aos abismos da morte (539), para que «os mortos ouvissem a voz do Filho do Homem e os que a ouvissem, vivessem (Jo 5, $25)^{290}$.

A mais antiga das interpretações do Descensus parece ter sido a da pregação de Cristo na morada dos mortos. Em algumas representações iconográficas ${ }^{291}$ o Salvador é representado na morada dos mortos com o livro (ou rolo) dos Evangelhos em sua mão.

A escassez de textos bíblicos, que fundamentassem a doutrina da descida de Cristo aos infernos, fez com que os Padres buscassem apoio em outras obras da literatura apócrifa. O texto apócrifo, conhecido como Pseudo Jeremias, é uma das passagens mais antigas que se usavam para fundamentar a pregação de Cristo aos mortos, por ocasião de sua descida. Encontramo-lo, pela primeira vez, em Justino de Roma, em seu Diálogo com o judeu Trifão. No texto, Justino acusa os judeus de mutilarem as Sagradas Escrituras, retirando delas passagens "nas quais se demonstra que esse mesmo Jesus crucificado foi claramente anunciado como Deus e homem, e que haveria de ser crucificado e morrer"292. Segundo Justino, "das palavras do profeta Jeremias também eliminaram esta passagem: 'O Senhor, o Deus santo de Israel, lembrou-se de seus mortos, dos que dormiram na terra amontoada, e desceu até eles para anunciar-lhes a sua salvação",293.

\footnotetext{
${ }^{290}$ CEC, 635.

${ }^{291}$ PASSARELLI, G., Iconos. Festividades Bizantinas, 1999, p. 22 (Cf. figura 3 p. 287).

292 JUSTINO, Diálogo com Trifão, 71.

${ }^{293}$ Ibid. 72,4.
} 
Que o texto gozava de prestígio entre os antigos cristãos comprova-se pelo uso que Santo Irineu de Lyon faz dele como fundamentação escriturística da descida de Cristo aos Hades. Mas esse mesmo uso mostra as dificuldades de estabelecer sua relação com nosso tema: além das diferentes versões apresentadas por Irineu, em uma ocasião ele o atribui a Jeremias (AH IV,22,1), em outra, na mesma obra, o atribui a Isaías (AH III,20,4), em outras, a um dos profetas, sem especificar qual (AH IV,33,1 e 33,12; V,31,1).

De origem incerta, o texto deve ter surgido em ambiente cristão (o que esvaziaria o valor da argumentação de Justino), podendo ser parte de um texto apócrifo atribuído a Jeremias (que conteria também a citação apresentada por Mt 27,8-10?), ou um midraxe cristão, acrescentado ao livro de Jeremias (mas, nesse caso, a qual passagem?). De qualquer modo, não se encontram em nenhuma versão reconhecida das Sagradas Escrituras ${ }^{294}$.

Não é possível estabelecer sua data de origem e, na hipótese de não ser de origem cristã, é difícil definir seu sentido original; na hipótese (mais provável) de possuir origens cristãs, o texto seria um antiquíssimo testemunho da afirmação da descida de Cristo à morada dos mortos e, conforme a versão que dele aceitarmos $^{295}$, de sua pregação aos que lá estavam.

${ }^{294} \mathrm{O}$ texto aparece cinco vezes na $\mathrm{AH}$ e uma vez na Démonstration de la prédication apostolique 78;1995, 192. (SChr, 406): O Senhor, o Santo de Israel, lembrou-se de seus mortos adormecidos na terra da sepultura e desceu para lhes anunciar a boa-nova da salvação com que os salvaria (AH. III,20,4). O Senhor, o Santo, lembrou-se de seus mortos que já tinham adormecido na terra lodocenta, desceu até eles para os tirar de lá e salvá-los (Ib IV,33,12). O Senhor se lembrou de seus santos mortos, dos que antes adormeceram na terra das sepulturas e desceu até eles para tirálos de lá e salvá-los (Ibid V,31,1);

${ }^{295}$ Nas versões mencionadas em AH IV, 33,12; V, 31,1 e IV, 33,1 não se faz menção de um anúncio aos mortos. 
Ainda o Evangelho de Pedro, obra apócrifa, datada provavelmente da primeira metade do século II $^{296}$, conhecida por Orígenes ${ }^{297}$ e Eusébio de Cesaréia $^{298}$, encontramos uma referência à pregação do Senhor aos mortos. Quando Cristo é retirado do sepulcro por dois anjos gigantescos, seguido pela cruz, "ouviram uma voz vinda dos céus que dizia: 'Pregaste para os que dormem?' e da cruz fez-se ouvir uma resposta: 'Sim,"299.

Também um pequeno ágrafo, de autor, destinatário e local de composição ignorados, citado por Clemente de Alexandria, se refere à pregação do Senhor aos mortos: "O Inferno disse à Perdição: 'Sua aparência nós não vimos, mas sua voz, nós a ouvimos ${ }{ }^{300}$. O texto era bastante conhecido na antiguidade, sendo tido como divinamente inspirado, inclusive pelos Padres da Igreja, dentre os quais podemos citar Hipólito de Roma e Epifânio de Salamina ${ }^{301}$.

\begin{abstract}
296 Por varios testimonios de los Padres de la Iglesia parece indudable que en torno al siglo II circuló en algunos ambientes reducidos un evangelio atribuido a Pedro. Los Padres coinciden en afirmar que este evangelio estaba falsamente atribuido al apóstol, contenía elementos añadidos a la recta doctrina del Salvador y fue rechazado y considerado como apócrifo. Históricamente este hecho debió reducir mucho su posible influencia EDOM M. PABLO, El Evangelio de Pedro, Salamanca, 2015, Ediciones Sígueme, p. 27.

297 ORIGENES, Commentaire sur l'Évangile selon Matthieu 10,17 (Tome I Livres X et XI. Introduction, traduction et notes par Robert Girod, 1970 ; SC 162,216.

${ }^{298}$ EUSÉBIO DE CESARÉIA, História Eclesiástica. VI,12,2 (Patrística 15, p. 295).

${ }^{299}$ EVANGELHO DE PEDRO, 10,41-42. In: Apócrifos da Bíblia e pseudo-epígrafos, p. 563. "El diálogo entre la voz celestial y la voz desde la cruz evidencia el motivo cristiano del descenso de Cristo a los infiernos y la predicación a los muertos, que se asienta sobre el tema veterotestamentario del Hades. Como en el EVPe, en los relatos canónicos tampoco se narra un descenso a los infiernos o la predicación a los que duermen. Sin embargo, ambos motivos se presuponen (cf. Mt 27,52) o se mencionan en otros lugares del Nuevo Testamento, especialmente en textos asociados con la figura de Pedro (Hch 4,6; Hch 2, 24s; 1Pe 3,18-19). Es el anuncio primitivo de la resurrección el que fundamenta los motivos del descenso y de la predicación. El descenso subraya que Jesús realmente conoció la muerte y que fue al lugar de los muertos o Hades. Por eso resucitó de entre los muertos (Hch 3,5; Rm 4,24; 1Pe 1,21. El regresso a la vida supone la victoria sobre el Hades y las garras del Sheol preconizada en la resurrección de Lázaro $(J n$ 11,44) y anunciada repetidamente por Jesús (cf. Mc 8,31; 9,31; 10,34 y paralelos). Jesús anuncia la predicación a los muertos, que constata que la salvación non tiene fronteras y afecta tanto a los vivos como a los fallecidos" EDOM M. PABLO, El Evangelio de Pedro, Salamanca, 2015, Ediciones Sígueme, p. 91-92.

${ }^{300}$ Clemente interpreta o texto, opondo-se à personificação dos Hades: "não é o lugar que recebendo uma voz disse as palavras que acabamos de citar, mas que aqueles cuja residência estava" CLEMENTE DE ALEXANDRIA, Les Stromates VI 45,1, 1999, p. 151-153 (SChr, 446. 301 Il est invoque comme um texte scripturaire non seulement dans le passage de Clément d'Alexandrie que nous venos citer, mais aussi dans la notice que la Refutation de toutes les hérésies, consacre aux Naassènes et dans une homélie qui a circulé sous le nom d'Epiphane de Salamine. Il est cité sans être formellement identifié comme «Écriture » par Clément d'Alexandrie pour commenter 1P 3,19 et dans un sermon pseudo-hippolytien. On le retrouve, enfin, incorporé dans le récit des Actes de Thomas et des Questions de Barthélemy. (GOUNELLE, R., La descente $d u$ Christ aux enfers. Institutionnalisation d'une croyance, 2000, p. 41-42). Gounelle é de opinião que o ágrafo seja de origem síria (Ibid. p. 46).
\end{abstract}


Na mesma época, temos o Pastor de Hermas

uma obra estranha, e, ao mesmo tempo, um dos escritos mais considerados da antiguidade cristã. Estranha enquanto está vazada no gênero apocalíptico, cuja essência decorre dos diálogos obtidos através de visões de seres celestes. /.../ Esta obra foi, por muito tempo, tida como inspirada, inclusive a colocaram no Cânon do NT. As frequientes referências que se encontram dela em vários Padres escritores, demonstram a alta estima em que era tida ${ }^{302}$.

Nessa obra, de cunho marcadamente eclesiológico, o autor professa a necessidade absoluta do batismo para ingressar na Igreja e na salvação da qual ela é portadora. Na nona parábola, os justos da antiga Aliança, que haviam morrido antes da vinda do Salvador, são apresentados como pedras que subiam do abismo para serem colocadas na construção da torre (Pastor 80,3; $9^{\mathrm{a}}$ Parábola.), que é a Igreja (Pastor 90,1), depois de passarem pela Porta (símbolo de Cristo e do batismo; Pastor 80,4). “As dez primeiras (pedras), colocadas no alicerce, é a primeira geração de homens justos; as vinte e cinco seguintes são a segunda (geração de homens justos); as trinta e cinco seguintes são os profetas de Deus e seus servos" (Pastor 92,4).

Isso pode acontecer porque "os apóstolos e doutores que anunciaram o nome do Filho de Deus, adormecidos no poder e na fé do Filho de Deus, o anunciaram àqueles que tinham morrido antes deles, e lhes deram o selo do anúncio" (Pastor, 93,5). Ou seja, a missão que receberam do Salvador, de anunciar o Evangelho e batizar as nações (Mt 28,19), os apóstolos continuaram a cumprí-la após terem morrido, possibilitando aos mortos (justos da Aliança antiga) o acesso à salvação ${ }^{303}$.

Temos, pois, uma visão bastante peculiar do Descensus ad inferos e da pregação feita aos mortos, realizada desta vez, não por Jesus em pessoa, mas pelos seus apóstolos. A nós, não restam dúvidas que a ideia depende de uma doutrina anterior da descida e pregação do próprio Cristo, que o autor transferiu para os apóstolos, em razão de seu pensamento eclesiológico.

\footnotetext{
${ }^{302}$ FRANGIOTTI, R., Introdução à obra do Pastor de Hermas. In Padres Apostólicos, p. 161.

${ }^{303}$ A ideia de um batismo administrado na morada dos mortos aparece também no apócrifo Epístola dos Apóstolos, onde é o próprio Jesus quem o administra: "Per questo sono sceso al luogho di Lazaro e ho predicato ai giusti e ai profeti, perché potessero uscire dalla quiete di laggiù e venire a quella di lassù. Ho steso su loro La mia destra com l'acqua del battesimo, perdono e savezza de ogni male" (Epistola degli Apostoli, 27)" ANCONA, G., Disceso agli inferi. 1999, p. 38.
} 
O mesmo se pode dizer da curiosa "descida de João Batista aos infernos", atestada pelo apócrifo Atos de Pilatos (ou Evangelho de Nicodemos) ${ }^{304}$, por Hipólito $^{305}$ e por Orígenes ${ }^{306}$.

No que se refere aos Padres, o tema da pregação de Jesus aos mortos aparece indiretamente afirmado por Santo Inácio de Antioquia, em sua epístola aos Magnésios ${ }^{307}$. Afirmação mais explícita encontramos em Hipólito (que o une ao tema da vitória) $)^{308}$. Mas é Santo Irineu († por volta de 202) quem o desenvolve com maior profundidade. O tema aparece na obra Adversus Haereses, na refutação da heresia marcionita, que rejeitava toda economia do antigo Testamento. Dizia o bispo de Lyon acerca de Marcião:

\begin{abstract}
${ }^{304}$ No texto João fala aos mortos: Eu sou João, o último dos profetas, aquele que preparou os caminhos do Filho de Deus e pregou a penitência ao povo para remissão dos pecados. O filho de Deus veio ao meu encontro e, ao vê-lo de longe, disse ao povo: 'Eis o Cordeiro de Deus, aquele que tira os pecados do mundo' /.../ E por isso mesmo também enviou-me a vós para anunciar a chegada do Filho de Deus unigênito a este lugar, a fim de que aquele que acreditar seja salvo, e quem não acreditar seja condenado. Por isto recomendo a todos que, enquanto o virdes, adoreis somente a ele, porque esta é a única oportunidade de que dispondes para fazer penitência pelo culto que rendestes aos ídolos enquanto vivíeis no mundo vil de antes e pelos pecados que cometestes; isto já não poderá ser feito em outra ocasião. ATOS DE PILATOS XVIII, 2, DESCIDA DE CRISTO AO INFERNO 2, versão grega, in Apócrifos e pseudoepigráficos da Bíblia, p. 552.

305 (João Batista) depois de ter sido morto por Herodes, foi evangelizar aqueles que estavam nos infernos, apresentando-se lá como precursor, para tornar conhecido que desceria também o Salvador, para resgatar as almas dos santos das mãos da morte. HIPÓLITO, O Anticristo, 45 em http://www.earlychristianwritings.com/text/hippolytus-christ.html. Acessado em 23 de Novembro de 2010 .

306 João Batista desceu nos infernos para anunciar Cristo, para predizer Aquele que lá desceria (Homilia sobre a pitonisa de Endor, comentando Mt 11,3; In libr. Reg. hom. 2, PG 12,1024A). Opondo-se a Orígenes temos um fragmento de uma Homilia sobre o Evangelho de Lucas, de São Cirilo de Alexandria: Muitos preferem entendê-lo assim: certamente porque o Batista havia sido levado à mansão dos mortos com violência por Herodes. Precedendo a Cristo e para descer primeiro aos Hades, pergunta - dizem - se este era o que tinha de vir para libertar aos que jaziam nas trevas e nas sombras da morte. Recusamos absolutamente esta proposta. Na Escritura inspirada, nunca encontramos que o Batista anunciasse antecipadamente aos espíritos encerrados nos Hades, e que seriam iluminados com seu esplendor na vinda do Salvador. (PG 72, 611ss).

${ }^{307}$ Como podemos viver sem aquele que até os profetas, seus discípulos em espírito, esperavam como Mestre? Foi precisamente aquele que justamente esperavam, quem ao chegar, os ressuscitou dos mortos. (INÁCIO DE ANTIOQUIA, Mag IX,2)

308 Así indicó toda la autoridad entregada del padre al Hijo, que ha sido designado rey de los celestiales, terrearles e infernales, y juez de todos: de los celestiales porque era el Logos engendrado del corazón del Padre antes de todos los demás; de los terrenales, porque también fue engendrado como hombre entre los hombres, remodelando a través de sí mismo a Adán; y de los infernales, porque también fue uno más entre los muertos, predicando la buena noticia a las almas de los santos y por medio de su muerte venciendo la muerte. (HIPÓLITO, El Anticristo, Madrid: 2012, Editorial Ciudad Nueva, p. 73-74).
\end{abstract}


como verdadeiro porta-voz do diabo que fala tudo o que é contrário à verdade, que Caim e seus semelhantes, os sodomitas, os egípcios e seus semelhantes, e todos os pagãos que praticaram toda espécie de maldades foram salvos pelo Senhor, quando desceu aos infernos e levou consigo ao seu reino os que acorreram a ele. Porém, segundo a serpente que falou em Marcião, Abel, Henoc, Noé e os outros justos, os patriarcas descendentes de Abraão com todos os profetas e os que agradaram a Deus não compartilharam da salvação. Com efeito, diz ele, sabendo todos eles que Deus estava sempre a tentá-los, pensaram também naquele momento numa nova tentação e não foram ao encontro de Jesus e não acreditaram no seu anúncio: deste modo suas almas permaneceram nos infernos ${ }^{309}$.

Opondo-se a ele, Irineu afirma que a vinda e a pregação de Jesus junto aos mortos não tinham como destinatários os ímpios, mas os justos da antiga Aliança. Estes, mesmo tendo sido acusados pelas Escrituras de muitos pecados, foram perdoados por ocasião da vinda do Senhor (AH IV, 31,1).

Por isso o Senhor desceu às partes inferiores da terra para levar também a eles a boa-nova de sua vinda, que é a remissão dos pecados para os que crêem nele. Crêem nele todos os que nele esperaram, isto é, que anunciaram a sua vinda e cooperaram com suas economias, os justos, os profetas e os patriarcas. A eles, como a nós, perdoou os pecados que não lhes devemos mais imputar, se não quisermos desprezar a graça de Deus (AH IV, 27,2).

Irineu diz que aprendeu essa doutrina do "Presbítero", personagem que não conseguimos identificar, mas que afirma ter ouvido dos Apóstolos e seus sucessores (AH IV, 27,1). Para fundamentar ainda mais a doutrina, Irineu recorreu também ao Pseudo-Jeremias, obra que ele tinha como canônica: "O Senhor, o Santo de Israel, lembrou-se de seus mortos adormecidos na terra da sepultura e desceu para lhes anunciar a boa-nova da salvação com que os salvaria” (AH III,20,4). A “evangelização" mencionada no texto ${ }^{310}$ refere-se ao anúncio da salvação, pelo que a afirmação não difere fundamentalmente da ideia da descida do Senhor como libertação dos justos (que apresentaremos a seguir). Não há no pensamento de Irineu a ideia de uma conversão post mortem, antes, o contexto de oposição às heresias de Marcião, exclui qualquer menção da salvação oferecida aos ímpios no além ${ }^{311}$.

\footnotetext{
${ }^{309} \mathrm{AH}, \mathrm{I}, 27,3$.

${ }^{310}$ A tradução latina que nos restou do original grego de Irineu diz: Commemoratus est Dominus Sanctus Israel mortuorum suorum qui dormierant in terra sepultionis; et descendit ad eos evangelizare salutem quae est ab eo, uti salvaret eos. (AH III, 20,4).

${ }^{311}$ Um estudo mais completo acerca do tema pode ser encontrado em ORBE A., El 'Descensus ad inferos' y San Irineo, in: Gregorianum, 68, (1987) 485-522.
} 
Com Clemente de Alexandria a interpretação da descida de Cristo à mansão dos mortos e sua pregação aos que ali estavam, sofreu uma alteração que afetou profundamente as gerações posteriores, tendo sido ele o primeiro dos Padres a associar a doutrina da Descensus com o texto da Primeira Carta de Pedro 3,18-20.

Incentivador da filosofia, Clemente acreditava que a vinda do Logos fora preparada entre os pagãos pelos filósofos, assim como o fora pela a Lei e os Profetas entre os judeus. Acreditava também, que a salvação ou a condenação só poderiam ser dadas com justiça após a pregação do Evangelho: "Seria uma grande injustiça se aqueles que saíram desta vida antes da vinda do Senhor, houvessem tomado parte na salvação ou no castigo sem haver sido evangelizados, ou sem oferecer razão do que acreditavam ou não" (Stromata. VI,48,4). Para tanto, era necessário que os que já haviam morrido antes da vinda de Cristo recebessem também o anúncio do Evangelho que lhes possibilitaria a escolha pela salvação.

Desse modo "os que viveram na justiça segundo a Lei”, os justos da Antiga Aliança mortos antes da vinda do Senhor, receberam dele a pregação do Evangelho, quando Ele, após sua morte, foi pregar aos mortos. Do mesmo modo, os falecidos que "que viveram na justiça segundo a filosofia" receberam também o anúncio do Evangelho, que "os apóstolos, imitando ao Senhor, também pregaram nos Hades" (Stromata VI, 45,5).

Clemente harmoniza, pois, as duas versões da pregação entre os mortos que julgava ter encontrado: a pregação realizada por Cristo, segundo ele atestada em 1Pd 3,18-20, e a pregação feita pelos apóstolos, atestada (como vimos) pelo Pastor (obra que na época muitos tinham por canônica).

Ainda que não fosse um apocatasta, visto que admitia a pregação de Cristo e dos apóstolos apenas aos justos (judeus ou pagãos), ao entender a pregação aos mortos, não apenas como anúncio do perdão, mas como convite à conversão ${ }^{312}$, Clemente introduziu a ideia de conversão post mortem que seria depois desenvolvida por Orígenes.

\footnotetext{
312 Pois, eu opino, os melhores discípulos têm de ser imitadores de seu Mestre tanto aqui como ali (i.é, nos Hades), para converter aos que provém dos judeus e dos pagãos. (CLEMENTE DE ALEXANDRIA, Les Stromates VI 45,5, 1999, p. 153 (SChr, 446).
} 
Também Orígenes falou amplamente da descida e da pregação de Cristo aos mortos. Aclamado por alguns e condenado por outros, seu pensamento é bastante complexo e sua análise ultrapassa os limites de nosso trabalho. Vale, porém, lembrar que o Adamantino se limitava, muitas vezes, a apresentar suposições $^{313}$, pelas quais não são de todo justas as condenações que lhe foram feitas, principalmente por terem sido suas ideias julgadas mais tarde fora de seu contexto e, possivelmente extremadas. No que se refere ao nosso tema, Orígenes é uma testemunha privilegiada da doutrina da descida e da pregação de Cristo aos mortos, que aparece diversas vezes em suas obras ${ }^{314}$.

Entendendo que a Escritura afirmava a salvação de muitos injustos do tempo da Antiga Aliança (os habitantes de Sodoma, cf. Mt 10,15; os ninivitas, Lc 11,32), Orígenes interpretou os castigos divinos como corretivos, como uma forma de instrução. Ainda que admitisse uma condenação definitiva, para o Diabo, os habitantes de Cafarnaum (Mt 11,23), o convidado sem a veste nupcial (Mt 22,11-13) 315 $^{315}$ (pelo que não parece justa a acusação que lhe fazem de ser apocatasta), Orígenes, como Clemente, admitiam a possibilidade da conversão após a morte, deixando, em última análise, o problema nas mãos da Providência divina. Por isso, entende a descida e a pregação de Cristo junto aos mortos como uma oferta da salvação feita no além. Respondendo as objeções de Celso, afirmou a respeito de Cristo que, "despojada sua alma do corpo, ele foi se entreter com as almas despojadas do corpo, e converteu a si as que queriam se converter ou que ele via mais bem preparadas, por motivos que ele conhecia" ${ }^{\text {316. }}$.

\footnotetext{
313 ORÍGENES, Traité des Principes II, 6,2, 1978, p. 173 (SChr, 253).

${ }^{314}$ Além dos textos já citados, encontramos referências em: Comei depressa. É a Páscoa para o Senhor, isto é, a 'passagem' do Senhor. Aquele que atravessou os limites fixados por Deus por causa da desobediência de Adão é, com efeito, o Senhor, que debilitou o aguilhão da morte e destruiu seu poder, dando, pela pregação do Evangelho aos espíritos que estavam aprisionados no Hades um meio para 'atravessar' e proporcionando-lhes também um meio de subir e entrar no céu, por sua própria ascensão, uma vez elevadas as portas e portais para a sua entrada. (ORIGENES, Sobre a Páscoa apud LANCHO, op. cit.). Também no fragmento de um comentário ao Evangelho de João: Tomás dice: "Vayamos a morir con él". Había leído las profecías relativas al Salvador y también había oído decir, naturalmente, que al Hijo de Dios le quedaba por cumplir la economia relativa a las almas, que había debido cumplir descendiendo al lugar de ellas, para ir a predicar a los espíritus prisioneros, que en otro tiempo habían sido rebeldes). Así pues, habiendo oído decir:"Yo voy a despertarlo", él entendía que Lázaro no podía ser desatado y resucitado de entre lós muertos sino sólo a condición de que Jesús descendiese al lugar de las almas. Ibid, 203.

${ }^{315}$ Ibid. II, 5,2, p. 173(SChr, 166).

${ }^{316}$ Contra Celso II, 43.
} 
Orígenes relaciona a descida de Cristo à morada dos mortos a outros temas, que mais tarde serão desenvolvidos por outros teólogos. Em sua obra aparecerem relacionados ao Descensus o tema da solidariedade (compaixão) de Cristo pela humanidade ${ }^{317}$, o Descensus como uma continuação/radicalização da encarnação do Verbo $^{318}$ (temas retomados, mais tarde, como veremos, pelo teólogo suiço Hans Urs von Balthasar).

\subsection{3 - A descida de Cristo à morada dos mortos como vitória sobre os poderes infernais.}

Na expressão «Jesus desceu à mansão dos mortos», o Símbolo confessa que Jesus morreu realmente, e que, por ter morrido por nós, venceu a morte e o Diabo "que tem o poder da morte" $(\mathrm{Heb} 2,14)^{319}$.

Outra importante interpretação soteriológica do Descensus ad infera é a da vitória de Jesus sobre as forças do mal, bastante explorada nos apócrifos, que personificando a morada dos mortos (como já o fizera a Sagrada Escritura), descrevem com muita criatividade a descida do Senhor aos infernos, sua luta e vitória sobre as potências diabólicas.

No Evangelho de Nicodemos ${ }^{320}$, um dos mortos que ressuscitaram por ocasião dos eventos descritos em Mt 27,52-53 relata o que viu acontecer na morada dos mortos, por ocasião da Paixão de Jesus:

\footnotetext{
317 “Se è disceso sulla terra, ciò è stato per compassione... p. 67. Ibid. Homilia sobre Ezequiel, 6,6.

318 Comentado a passagem do evangelho de João, na qual o Batista afirma não ser digno desatar as sandálias de Jesus, afirma: Também o texto sobre as sandálias tem um sentido místico, não deve ser passado em silêncio. Penso que a encarnação, quando o Filho de Deus toma uma carne e osso, constitui uma das sandálias, e a descida ao Hades, seja o que de for que se há de entender pelo termo 'Hades' e a viagem em espírito até a prisão, a outra. Da descida ao Hades se diz no Salmo 15: 'não abandonarás minha alma no Hades'; da viagem até a prisão em espírito, na epístola católica de Pedro ... (segue texto de 1Pd 3,18-19). (SCh 157, Paris 1970, p. 260-262).

${ }^{319}$ CEC 636.

${ }^{320}$ Une théologie de l'histoire s'y fait entendre, même si elle est présentée comme tout à fait primitive et quelle que soit la conception du monde (physico-mytique ?) qui s'y rattache. Mais l'œuvre du Christ comporte aussi la victoire sur la Puissances infernales qui apparaissent sous trois formes : l'Hadès, la mort et Satan. Le cadre était assez large pour recevoir un développement mythique qui atteint peut-être son apogée dans l'Évangile de Nicodème. GRILLMEIER, CARDINAL ALOIS, Le Christ dans la tradition chrétienne. De l'âge apostolique au concile de Chalcédoine (451), LES ÉDITIONS DU CERF, PARIS, 2003, p. 263.
} 
Então, de novo veio uma voz que dizia: 'Levantai as portas'. O Inferno, que ouviu repetir essa voz, disse como se não se apercebesse: 'Quem é este Rei da Glória?' E os anjos do Senhor responderam: 'O Senhor forte e poderoso, o Senhor, o poderoso na batalha'. E num instante, à convocação de conjuração dessa voz, as portas de bronze tornaram-se pequeninas e os ferrolhos de ferro ficaram reduzidos a pedaços, e todos os defuntos acorrentados viram-se livres de suas correntes e nós dentre eles. E entrou o Rei da Glória na figura humana, e todos os antros escuros do Inferno foram iluminados. Em seguida o Inferno começou a gritar: 'Fomos vencidos, ai de nós! Mas quem és tu, que possuis tal poder e força? /.../ E então o Rei da Glória agarrou o grande sátrapa Satanás pelo pescoço e entregou-o aos anjos dizendo: 'Amarrai com correntes de ferro suas mãos, seus pés, seu pescoço e sua boca'. Depois colocou-o nas mãos do Inferno com a seguinte recomendação: 'Toma-o e o mantém bem preso até minha segunda vinda' ${ }^{321}$

Envolto em um linguajar mitológico, o apócrifo apresenta a profissão de fé cristã na "extensão da obra redentora a todos os homens de todos os tempos e de todos os lugares, porque todos aqueles que se salvaram se tornaram participantes da redenção" 322 .

Também nos Odes de Salomão $(42,11-20)$ aparece o tema da vitória do Senhor no mundo dos mortos: "Os infernos me viram e foram esmagados. A morte me vomitou, e muitos comigo" 323 .

O tema também esteve bastante presente nos Padres da Igreja. Como vimos, no pensamento de Santo Irineu, a doutrina da descida de Cristo à morada dos mortos aparece nas duas vertentes da antiga tradição, a pregação aos mortos e vitória contra os poderes infernais. Tendo já analisado o tema da pregação, vejamos agora o da vitória.

Assim como na interpretação do Descensus como pregação, também aqui Irineu utiliza o texto apócrifo do Pseudo-Jeremias ${ }^{324}$ para falar da descida do Senhor como libertação e salvação dos que haviam já morrido: "O Senhor, o Santo, lembrou-se de seus mortos que já tinham adormecido na terra lodocenta, desceu até eles para os tirar de lá e salvá-los" (AH IV, 33,12). "O Senhor se lembrou de seus santos mortos, dos que antes adormeceram na terra das sepulturas e desceu até eles para tirá-los de lá e salvá-los” (AH V, 31,1); e, numa citação não

${ }^{321}$ DESCIDA DE CRISTO AO INFERNO (Versão Grega) 5,3-6,2. In: Apócrifos da Bíblia e pseudo-epígrafos, 2005 pp. 554-555.

${ }^{322} \mathrm{CEC}, 634$.

${ }^{323}$ Texto citado conforme CHIALÀ, S., Discese agli inferi, p. 46.

${ }^{324}$ AH III,20,4; AH IV 22,1; Démonstration de la prédication apostolique 78, SChr 406, p. 192. 
literal: "aquele que lembrando-se dos pais já adormecidos, desce até eles para libertá-los e salvá-los" (AH IV, 33,1).

O Senhor desce à morada dos mortos para libertar os justos da antiga Aliança ("seus santos mortos" AH V 31,1; “os pais já adormecidos” AH IV, 33,1), "pelos quais o Filho de Deus ainda não tinha sofrido /.../. Para eles a morte do Senhor foi a remissão de seus pecados" (AH IV, 27,2). Não faz, pois, sentido afirmar como pretendem alguns $^{325}$, que Irineu se referisse a ressurreição antecipada dos justos: a salvação oferecida nos infernos foi o perdão dos pecados.

O tema da vitória sobre o Diabo, obtida por Cristo pela ocasião de sua descida aos infernos ${ }^{326}$, aparece também na famosa homilia pascal de Melitão, bispo de Sardes († por volta de 180). Nela, o próprio Cristo se apresenta como o vencedor: "Eu sou, diz o Cristo, eu sou quem destruiu a morte, quem venceu o inimigo, quem pisoteou o Hades, quem atou ao forte, quem arrebatou para o alto dos céus"327. A homilia faz referência à parábola do combate (Mc 3,27), que mencionamos acima.

Encontramos o mesmo tema nos Sermões de São Cesário de Arles ${ }^{328}$ e Orígenes: "Para que desceu Cristo aos infernos? Para vencer a morte ou para ser vencido? Ele desceu àquele lugar não como servo, dos que ali estão, mas como Senhor para combater" 329 . Também em De Principiis, refere-se a Jesus como "a um triunfador sobre o reino da morte, que volta do reino da morte com o saque $^{330}$,

\footnotetext{
325 Helcion Ribeiro, em nota a AH III, 20,4: O autor repete a citação atribuindo-a, porém, a Jeremias. Todavia, tal texto não se encontra na Bíblia atual; antes parece ser um midraxe sobre Jeremias, cultivado em ambiente judaico-cristão, onde se discutia a sorte dos santos, patriarcas e profetas de Israel falecidos. E sua importância dogmática se prende ao objetivo da descida de Cristo aos mortos: não apenas para anunciar-lhes a libertação futura, mas libertar de imediato os justos ressucitando-os corporalmente (não só suas almas), antecipando a ressurreição escatológica. ${ }^{326}$ A obra de Fra Angélico, Christ in Limbo mostra os demônios derrotados com a chegada de Cristo. (Cf. BARTZ, G., Master of Italian Art - Fra Angélico, 2007, p. 91; figura 4 p. 288). ${ }^{327}$ MELITÓN DE SARDES, Sur la Pâques 102 Paris: 1966, p 121 (SChr, 123).

${ }^{328}$ Questo leone, cioè Cristo, della tribù di Giuda, discese vittoriosamente negli inferi, per sottrarci dalla boca del leone ostile. Egli va a caccia per salvaci, ci carttura e ci rilascia, ci fa prigionieri por poi restituirci liberi alla nostra patria. (Sermão 119, in: CHIALÀ, S.; Discese agli inferi, 47)

${ }^{329}$ Hom 1Re VI, 6-7.

${ }^{330}$ ORÍGENES, De Principiis II, 6,2 em: http://www.earlychristianwritings.com/text/origen123.html. Acessado em 06 de Dezembro de 2010.
} 


\subsection{4 - A peculiar abordagem de Santo Agostinho.}

O pensamento de Santo Agostinho de Hipona acerca da descida de Cristo aos infernos apresenta tal peculiaridade que requer ser estudado à parte. Por outro lado, sua interpretação, como veremos, influenciou profundamente a teologia ocidental acerca do Descensus.

A teologia de Agostinho sobre a descida de Cristo à morada dos mortos é encontrada principalmente em sua Carta a Evódio ${ }^{331}$ († por volta de 424), bispo de Uzala. O bispo de Uzala mantinha correspondência direta com Agostinho, buscando conselhos do sábio, para ingressar na fé e evitar transgressões doutrinais.

Em carta enviada ao bispo de Hipona, Evódio perguntara, entre outras questões, "quais são aqueles espíritos dos quais, em sua epístola, Pedro dá testemunho do Senhor dizendo: 'morto na carne, vivificado no espírito, no qual foi também pregar aos espíritos encarcerados, etc'. Parece que estavam no inferno e, descendo, Cristo evangelizou a todos e libertou a todos graciosamente das penas e das trevas" ${ }^{332}$. Na Epístola 164 Agostinho tentou responder as diversas dificuldades que a passagem da Primeira Carta de Pedro apresenta.

Baseando-se no texto de At 2, 24.27, Agostinho entendia por "inferno" o lugar dos condenados: "Está bem claro que o Senhor, morto na carne, desceu aos infernos. Com efeito, não podemos contradizer a profecia que diz: Porque não deixarás minha alma no inferno. O mesmo Pedro o expõe nos Atos dos Apóstolos para que ninguém ouse entendê-lo de outro modo, nem desfigure suas palavras, nas quais afirma que ele dissolveu as dores do inferno, no qual era impossível que ele fosse retido. Quem, pois, senão um infiel, negará que Cristo esteve nos infernos?"333. O mesmo pode ser mais claramente percebido em outros escritos do santo bispo: "Dificilmente pode se encontrar nas Sagradas Escrituras a palavra ‘inferno' usada em um sentido bom. /.../ a palavra 'inferno' é tomada apenas no

\footnotetext{
${ }^{331}$ Ibid. 164 (PL 33, 709-718). O santo trata da questão também na Carta a Dardano, prefeito da Gália (Epist. 187,5, PL 33, 832-848), seu Comentário literal ao Gênesis (Genesi ad litteram XII, 33,63, PL 34, 481-482) e no Comentário ao Salmo 85,18 (Patrística 9/2, 863-864).

${ }^{332}$ Ibid. 163 (PL 33, 708).

${ }^{333}$ Ibid. 164,3; PL 33, 710.
} 
sentido de lugar de castigo" 334 . Contrariando a tradição (que supunha a visita e pregação de Cristo aos justos), para Agostinho (como também para Evódio) o “inferno", aonde desceu o Senhor, era o lugar dos condenados.

Mas, qual o sentido dessa "descida"? Teria a alma de Cristo experimentado a condenação? "Como podemos acreditar com piedade que a alma de Cristo desceu aos infernos?"335. Agostinho responde afirmando que o Senhor desceu aos infernos não como condenado, mas para ali atuar como Salvador: "nenhuma causa se apresenta para que o Salvador ali descesse, senão para salvar das dores" $" 336$.

Agostinho acreditava, assim como Evódio ${ }^{337}$, que com a ressurreição o inferno seria dissolvido; julgava que o Senhor ali fora para salvar apenas alguns, aqueles que deveriam ser libertados ${ }^{338}$.

Isso considerado, Agostinho recusa-se a ver ligação entre a passagem de 1Pd 3,18-20 e a doutrina do Descensus. Com efeito, tal identificação supunha diversos problemas:

- Por que Cristo teria pregado apenas à geração de Noé, sendo que muitos outros milhares haviam ido para os infernos antes da vinda e da Paixão do Senhor? E se Cristo, pregou a todos, porque Pedro cita apenas a geração de Noé como objeto da pregação de Jesus?

\footnotetext{
${ }^{334}$ Ibid. 187,2,6 (PL 33, 834). Também, Id: Utrum autem sinus ille Abrahae, ubi dives impius cum in tormentis esset inferni, requiescentem pauperem vidit, vel paradisi censendus vocabulo, vel ad inferos pertinere existimandus sit, non facile dixerim; Santo Agostinho tem dificuldade em situar "o seio de Abraão", onde os justos falecidos já encontravam o repouso: Aludo ainda a outra opinião: Talvez no próprio inferno haja uma parte mais abaixo, onde são arrojados os ímpios que pecaram mais. Com efeito, não podemos afirmar com certeza que Abraão não tenha estado nem alguma parte do inferno. O Senhor ainda não descera aos infernos a fim de retirar dali as almas de todos os santos que o haviam precedido. E, no entanto, Abraão estava no repouso ali. AGOSTINHO, Comentário aos Salmos, 85,18; Patrística 9/2 p.863.

${ }^{335}$ Epistola. 187,2,6 (PL 33, 834).

336 " ".../ nulla causa occurrit cur illo credatur venisse Salvator, nisi ut ab eius doloribus salvos faceret" (Ibid. 164,8).

${ }^{337}$ Ibid. 163 (PL 33, 708)

${ }^{338}$ Unde etiam quaeri solet, si nonnisi poenalia recte intelleguntur inferna, quomodo animam Domini Christi pie credamus fuisse in inferno. Sed bene respondetur ideo descendisse, ut quibus oportuit subveniret. (Ibid. 187,2,6, PL 33, 834).
} 
Falo dos muitos milhares de homens, que não conhecendo a Deus e prestando culto aos demônios e aos ídolos, do tempo de Noé até a Paixão Cristo emigraram dessa vida. Por que Cristo, encontrando-os nos infernos, não pregou a esses, mas somente aos que foram incrédulos no tempo de Noé, enquanto ele construía a arca? Se, ao contrário, Cristo pregou a todos, por que Pedro menciona somente aqueles, deixando sob silêncio a multidão inumerável de todos os outros? 339

- Notando o paralelismo dos textos de 1Pd 3,18-20 e 1Pd 4,6, Agostinho concluiu que se referiam ao mesmo tema e negou que pudessem estar relacionados com o Descensus. Com efeito, em 1Pd 4,6 afirma que "a Boa-nova foi pregada também aos mortos, a fim de que sejam julgados como os homens na carne, mas vivam no espírito, segundo Deus". Ora, os incrédulos do tempo de Noé não poderiam ser julgados como os homens na carne, pois já não a tinham mais e, na ocasião da descida de Cristo aos infernos, ainda não haviam recebido a carne de volta (com a ressurreição). Logo, conclui o santo, o Apóstolo Pedro se referia não aos mortos fisicamente, mas às "almas que se encontravam ainda no corpo e estavam presas nas trevas da ignorância como num cárcere" ${ }^{340}$.

- Ainda, a idéia de uma pregação aos mortos implicava a possibilidade da conversão após a morte. Se for dada oportunidade de conversão após a morte àqueles que, tendo morrido antes da vinda de Cristo não tiveram meios de conhecê-lo, deveria ser dada também a mesma oportunidade a todos aqueles que, em qualquer tempo, morressem sem conhecer o Senhor. E se todos pudessem se converter após a morte, ficaria esvaziada a necessidade da pregação missionária; seria melhor que as pessoas não conhecessem a Cristo nessa vida (com risco de rejeitá-lo) e recebessem a pregação salvadora no além. Como é óbvio, o santo considera essa afirmação uma "ímpia vanidade" ${ }^{341}$. Logo, segundo ele, o texto da Primeira Carta de Pedro não pode ser entendido em relação ao Descensus.

Agostinho, por fim, conclui que a pregação feita por Cristo aos incrédulos, do tempo de Noé, se deu não durante a descida do Senhor aos infernos, mas enquanto esses incrédulos ainda viviam na terra: "Ele, com efeito, desde o início do gênero humano, sempre veio, não com o seu corpo, mas com o espírito, a reprovar os malvados como Caim e antes até mesmo Adão e sua consorte, a

\footnotetext{
339 Ibid. 164, 2 (PL 33, 709).

${ }^{340}$ Ibid. 164, 16 (PL 33, 715).

${ }^{341}$ Ibid. 164, 4,13 (PL 33, 714): "impiae vanitatis est".
} 
consolar os bons e admoestar uns e outros de modo que alguns acreditassem para a própria salvação e outros permanecessem incrédulos para o próprio castigo" 342 .

Tal interpretação alegorizante influenciou a exegese de 1Pd 3,18-20, a ponto que Santo Tomás de Aquino, mesmo conhecendo interpretação diferente ${ }^{343}$, prefere a de Agostinho como a melhor explicação (melius exponit):

Agostinho, porém, dá melhor explicação, quando diz que essa pregação não deve se referir à descida de Cristo aos infernos, mas, à obra de sua divindade, exercida de desde o início do mundo. E este seria o sentido: 'Vindo em Espírito' de sua divindade, Cristo pregou por inspirações internas, bem como exortações exteriores feitas pelos justos, 'aos espíritos que se encontravam na prisão', ou seja, vivendo num corpo mortal, que é como que uma prisão da alma, 'aos que outrora foram incrédulos', ou seja, a pregação de Noé, 'quando se prolongava a paciência de Deus' pela qual se adiava a pena do dilúvio. Por isso, acrescenta: 'nos dias em que Noé construía a arca' ${ }^{344}$.

O pensamento de Santo Agostinho, porém, não está isento de problemas. Além da afirmação de um "inferno transitório", visto que admite que, com sua descida junto aos condenados, Cristo libertou alguns do castigo, mais grave parece ser a indeterminação dos motivos pelos quais esses foram libertados. Na carta a Dardano, prefeito da Gália, Agostinho afirma que Cristo desceu para libertar "aqueles que deveriam ser libertados" 345 . A afirmação abriu caminho para ideias predestinacionista ou, até mesmo, apocatástas, justamente a aquela doutrina que Santo Agostinho desejava refutar quando escreveu a Evódio.

Já na antiguidade estes temas foram retomados por alguns Papas. Assim, São Gregório I escrevendo ao presbítero Jorge (Carta Memor bonitatis, maio de 567) condenou a afirmação de que, ao descer aos infernos, Cristo teria ali salvado todos os que nele acreditaram ${ }^{346}$. Argumentou que se as obras, conforme a palavra do Apóstolo Tiago (Tg 2,20), são necessárias aos que crêem em Cristo, após a sua vinda, não poderiam ser menos necessárias aos que viveram antes de sua Encarnação. Conclui afirmando que "o Senhor, ao descer aos infernos, libertou

\footnotetext{
342 Ibid. 164,17 (PL 33, 716).

${ }^{343}$ A interpretação de Damasceno (Cf. ST. III, q. 52, a.2 ).

344 ST III, 52a.3, BAC, Madrid, 1994.

345 Epistola 187, 2,6 (PL 33, 834).

346 /.../ omnipotentem Dominum salvatorem nostrum Jesum Christum ad inferos descesndentem, omnes qui illic confiterentur eum Deum, salvasse, atque a pœnis debitis liberasse. (Epístola 15, PL $77,86)$.
} 
das cadeias infernais somente aqueles que, vivendo na carne, pela sua graça se mantiveram na fé e nas boas obras"347

No tempo do Papa Zacarias, a 3ª Sessão do Sínodo de Roma de 745 (25 de outubro) condenou os erros de Clemente, um sacerdote escocês, "que na sua estupidez afasta quanto foi estabelecido pelos santos Padres e todos os atos sinodais, e que introduz também para os cristãos o judaísmo, pregando [é licito] tomar a mulher do irmão defunto, e que além disso prega que o Senhor Jesus Cristo, logo que desceu aos infernos, tirou de lá a todos, pios e ímpios" ${ }^{\text {„34, }}$ privando-o de qualquer ofício sacerdotal e anatematizando-o.

\section{4 - As interpretações predominantemente cristológicas.}

Este o sentido primeiro dado pela pregação apostólica à descida de Jesus à mansão dos mortos: Jesus conheceu a morte, como todos os homens, e foi ter com eles, por sua alma, à morada dos mortos ${ }^{349}$.

Até o séc. IV na reflexão teológica concernente ao Descensus ad infera predominava, fundamentalmente, o enfoque soteriológico. Tal enfoque não foi posteriormente abandonado, antes retomou sua predominância depois do séc. V. Porém, nos sécs. IV e V (mesmo permanecendo a questão soteriológica) a ênfase se descolou para a temática cristológica ${ }^{350}$. Tal se deve a uma mudança de acento na própria cristologia, que de um enfoque mais "econômico" (a ação salvífica realizada por Cristo) passou a considerar principalmente o "ser em si" de Cristo. Assim, de uma "cristologia das duas fases", onde o binômio carne-Espírito, de caráter predominantemente funcional, servia para indicar as duas fases da história de Jesus Cristo (fase "segundo a carne”, antes da Ressurreição, e fase "segundo o

\footnotetext{
${ }^{347}$ Ibid. 870.

348 DHü 587.

${ }^{349}$ CEC 632, Tradução nossa, pois a tradução brasileira não corresponde aos textos latinos (editio typica) e francês (língua original), nos quais se afirma explicitamente a ida da "alma" de Cristo à morada dos mortos (anima Sua; par son ame).

${ }^{350}$ Avec la progression de la réflexion sur la personne du Christ, la doctrine de la descente reçut aussi une orientation plus proprement 'christologique'. On s'interrogeant alors sur le rapport entre la divinité et l'humanité du Christ, entre la divinité, l'âme et le corps, au moment de sa mort. Une caractéristique particulière de cette étape du développement de la doctrine de la descente fut la supposition de la 'descente du Logos'. Mais ce développement appartient plutôt au III siècle finissant au IV siècle. GRILLMEIER, C. A., Le Christ dans la tradition chrétienne. De l'âge apostolique au concile de Chalcédoine (451), 2003, p. 263.
} 
Espírito", após a Ressurreição, cf. Rm 1,3-4 ${ }^{351}$ ), passou-se a uma "cristologia dos dois planos", onde o binômio anterior foi progressivamente substituído pelo binômio Logos-carne, entendido em sentido vertical, com ênfase no momento da Encarnação.

Em relação ao nosso tema, a problemática deslocou-se de saber "o que Jesus operou com o Descensus" (questão soteriológica), para investigar "de que modo a pessoa de Jesus desceu aos infernos" (questão cristológica): a "estrutura" ou "composição" da pessoa de Jesus ${ }^{352}$.

Encontrando-se no período anterior às precisões do Concílio de Calcedônia, movendo-se basicamente no contexto de combate à heresia ariana, diversos Padres, particularmente os de tradição alexandrina, chegaram a ressaltar tanto a natureza do Lógos, a ponto de desvalorizar a plena natureza humana de Jesus $^{353}$. Isso se tornava particularmente grave na tendência de atribuir ao Lógos tudo que deveria se referir à alma de Jesus (tendência que evoluiu para a heresia apolinarista, que negava explicitamente a existência da alma de Cristo).

\footnotetext{
351 A cristologia arcaica movia-se predominantemente em perspectiva histórico-salvífica, interpretando a história de Jesus a partir de sua manifestação na história humana. Bem cedo, porém, colocou-se a questão de saber como Jesus, "nascido de Maria segundo a carne", foi constituído "Filho de Deus segundo o Espírito". A identificação de tal momento parece ter-se antecipado progressivamente da ressurreição ( $\mathrm{Rm} 1,4)$, ao batismo (momento no qual permaneceram muitos gnósticos), à concepção (Mt e Lc), até chegar à preexistência (Jo 1,1-3). Ver, a propósito, duas interessantes obras de Larry W. HURTADO que analisam a consciência progressiva acerca da divindade de Jesus a partir do estudo da devoção que lhe tributavam: Señor Jesucristo. La devoción a Jesús em el Cristianismo primitivo, (tradução de Francisco J. Molina de La Torre) Sígueme, Salamanca 2008 e (mais resumido) Come Gesù divenne Dio, (tradução deAngelo Fracchia) Paideia Editrice, Brescia, 2010.

${ }^{352} \mathrm{La}$ sombre image de l'Hadès fait donc partie, dans la pensée de l'Église primitive, du tableaux lumineux de la christologie de l'élévation qui englobe la Résurrection., l'Ascension et la Session à la droite du Père. On peut effectivement écarter complètement de la pensée sotériologique fondamentale, l'hypothèse de son insertion dans une vision concrète du monde (peut-être à trois niveaux) et un ajustement plus ou moins mythologique. Une certaine liberté domine quant à cette association. Dans optique de 1 P 3, 19-20, on voit l'action du Christ, habituellement désignée comme descensus ad inferos, probablement déjà saisie dans sa montée. Mis est-que la descente devient une montée en association avec l'image concrète du monde ? Cela n'est pas décisif. En tous cas, la descente a un caractère pascale (dans le semble du Vendredi-Saint, du Samedi-Saint et du jour de Pâques) du fait qu'elle est la victoire sur la mort, sur l'enfer et sur le Satan. Cependant, le lien entre la descente et la glorification n'a pas toujours la même intensité. Au cours des states postérieurs de la doctrine de la descente, où le Christ est considéré en état de séparation (de la divinité) de l'âme et du corps et où l'on réfléchit sur ce fait, le motif des Pâques ne transparaît guère. On parle du descensus in triduo mortis. GRILLMEIER, C. A., Le Christ dans la tradition chrétienne. De l'âge apostolique au concile de Chalcédoine (451), 2003, p. 264-265.

${ }^{353}$ Uma interessante apresentação do tema pode ser encontrada na obra de CANTALAMESSA, R., O mistério da transfiguração (tradução de Alda da Anunciação Machado), 2001, pp. 70-74 (O Cristo da escola alexandrina).
} 
No que se refere ao nosso tema, tal pensamento deveria conduzir à afirmação de que foi somente o Lógos que desceu aos infernos ${ }^{354}$, doutrina que não poderia deixar de apresentar dificuldades (numa época em que se entendia literalmente o descensus ad infera), visto que, sendo Logos divino onipresente, dele não se pode falar de um movimento, de uma descida aos Hades.

Alguns tentaram superar essa dificuldade, afirmando ter sido o corpo de Jesus que desceu aos infernos ${ }^{355}$, ou o Lógos unido ao corpo, ou ainda, o Lógos transformado em corpo. Contra estes escreveu Santo Atanásio de Alexandria, com afirmações que sofriam os limites da teologia de então. Para ele

o Lógos é a força da qual brota toda vida e movimento: o mundo encontra no Lógos o seu modelo, seu suporte, o seu ordenamento e vida (cf. Contra gentes, 44 [PG 25,88C]). Ele, em relação ao mundo, está na mesma relação que une a alma humana ao corpo; no entanto, entre Lógos e alma racional há somente uma evidente afinidade, não identidade. Isto se torna importante quando se tenta compreender La relação que existe entre o Lógos e a humanidade de Jesus Cristo. Assim, 'quando (Atanásio) considera o ser de Cristo, a sua atenção é imediatamente atraída para o Lógos e a sua relação com o corpo de Cristo, e vê essa relação como completamente análoga à relação Lógos-mundo, alma-corpo' [Grillmeier, Gesù Cristo, p. 588]. Ora, o corpo de Cristo é apenas uma parte do corpo mais amplo do universo e como o Lógos dá vida à totalidade, do mesmo modo e com maior razão vivifica parte dessa. O Lógos está no corpo de Cristo em toda a sua plenitude e transmite a esse corpo vida e potência; ele, porém, conserva sempre a sua transcendência. Em outros termos, o Lógos dá vida e movimento ao corpo de Cristo; tem uma função vivificante em relação à carne, até o ponto que para Atanásio não há possibilidade de espaço para a alma humana de Jesus Cristo. O Lógos tem sua atividade física mediada pela realidade corpórea da humanidade de Cristo... ${ }^{356}$.

Desse modo, a morte de Jesus é vista como a separação do Lógos do corpo. Por isso, quem desceu aos infernos foi o próprio Lógos. Opondo-se aos que afirmavam que o Lógos se transformara em carne, Atanásio afirma, após citar o conhecido texto de 1Pd 3,19:

\footnotetext{
${ }^{354}$ Teoria que os autores alemães irão chamar de Logosabstieg.

355 Tal parece ser a afirmação de Santo Efrém, o sírio: La divinità era nascosta nell'umanità e così la morte le si accostò. Uccise e venne uccisa. La morte uccise la vita che si trovava nella natura [umana di Cristo], e fu uccisa dalla vita chi si trovava al di fuori della natura [umana di Cristo, cioè nella sua divinità]. E poiché la morte non poteva consumarlo senza il corpo e anche lo sheol non poteva inghiottirlo senza carne, egli venne alla Vergine, affinché di qui un veicolo lo conducesse allo sheol... Con il corpo ricevuto dalla Vergine egli penetrò nel sheol, ne saccheggiò le ricchezze e ne vuotò i tesori... Questi l'abile figlio del falegname, che costruì la sua croce sopra lo sheol che tutto inghiotte e [così] fecce passare gli uomini al regno della vita. (Sermo de Domino nostro 3-4; Corpus Scriptorum Christianorum Orientalium 270, 3-4; apud ANCONA, G., Disceso agli inferi, p. 56-57).

${ }^{356}$ ANCONA, G. Disceso agli inferi, p. 53.
} 
Isso refuta completamente a loucura daqueles que dizem que o Lógos se converteu em carne e osso. Se assim fosse, não haveria sido necessário o sepulcro, pois o corpo mesmo teria ido pregar aos espíritos que se encontravam no Hades. Mas, na verdade, é somente o Lógos que foi pregar a esses, enquanto José envolvia o corpo em um lençol e o depositava sob o Gólgota. E assim era manifesto a todos que não era o Lógos, mas o corpo do Lógos ${ }^{357}$.

Afirmações semelhantes parecem poder ser encontradas também em Santo Hilário de Poitiers:

O que desceu é o mesmo que subiu. Ainda se poderá hesitar, dizendo que não foi Jesus Cristo o Homem ressuscitado dos mortos que se elevou acima de todos os céus e está à destra de Deus? Acaso se dirá que desceu aos infernos o corpo que jazia no sepulcro? Mas se o que desceu é o mesmo que subiu e não se acredita que o corpo tenha descido aos infernos e também não se duvida de que, ressurgindo dos mortos, tenha subido aos céus, que mais resta a não se a fé no mistério escondido, desconhecido pelo mundo e pelos príncipes deste mundo ${ }^{358}$.

Superada a heresia apolinarista, foi à alma de Cristo que a grande tradição atribuiu a descida à morada dos mortos ${ }^{359}$, o que é particularmente visível em São Cirilo de Alexandria, em cujas obras o tema do Descensus aparece muitas vezes, principalmente (dada a afinidade do tema) nas cartas que enviava a seus fiéis por ocasião da Páscoa ${ }^{360}$. Particularmente interessante é o uso que faz desta doutrina, em sua obra De Incarnatione Unigeniti, como meio de refutação do apolinarismo:

357 ATANASIO, Carta a Epicteto, PG 26, 1059AB; GRILLMEIER, CARDINAL ALOIS, Le Christ dans la tradition chrétienne. De l'âge apostolique au concile de Chalcédoine (451), LES ÉDITIONS DU CERF, PARIS, 2003, p. 638-639.

${ }^{358}$ HILÁRIO DE POITIERS, Tratado sobre a Santíssima Trindade (X,65), Paulus, São Paulo, 2005, p. 408.

359 A afirmação da descida da alma de Cristo aos infernos já podia ser encontrada em Orígenes, Catequese sobre o Sl 3,6: Por tanto decimos que nuestro Salvador Jesucristo, cuando soportó la muerte común por nosotros, entonces se durmió, verdaderamente entró en el sueño, cuando su alma fue separada del cuerpo. Del mismo modo que los que cogen el sueño, mientras el cuerpo yace, actúan según la mente, guiándose por ciertas imaginaciones que les vienen, y hacen algo sin ayuda ninguna del cuerpo, del que no necesitan, así, (también), aun cuando en todos los particulares la imagen no sea semejante a aquello que representa; no obstante, para que el alma se muestre operativa sin el cuerpo, del que ha sido separada y coge el sueño, después que se dice: "yo dormí", se añade, "y fui adormecido" . Y ¿qué hay de maravilloso, si de este modo el sueño del Salvador no fue absolutamente ocio para su alma, sino una cierta cesación del uso del cuerpo como instrumento? Esta (el alma) realiza por sí misma sus deberes /.../ Por tanto nada admirable que el Salvador diga: Dormí y entré en el sueño, como quien hiciera muchas cosas por la salvación de las almas en este tiempo en que está separado del cuerpo, como dice Pedro en su epístola católica /.../ Después del sueño, el Padre, tomándole, lo despertó. LANCHO p. 208-209, que cita conforme B. ReICKE, The Disobedient Spirits and Christian Baptism. A Study of 1 Pet .III:19 and its Context, København 1946, p. 30-31

${ }^{360}$ Carta Festal I, 6,162-185 (SChr 372, p. 184-187) Carta Festal II, 8,63-89 (SChr 372, p. 231.233); Carta IV,6,112-114 (SChr 372, p. 272); Carta V,1,29ss (SChr 372, p. 284); Carta VI, VI,12,72-73 (SChr 372, p. 396); Carta VII,2,185ss (SChr 392, p. 52); Carta VIII, 6,130-131 (SChr 392, p. 110); Carta IX,6,97ss (SChr 392, p. 174), Carta X, 5,58s (SChr 392, p. 238); Carta XI, 8,84-90 (SChr 392, p. 308); Carta XII , 6, 40-49 (SChr 434 p. 76-78); Carta XIII,4,114 (SChr 434, p. 116); Carta XIV,2,352 (SChr 434, 162); Carta XV, 4,6ss (SChr 434 p.198); Carta XVI 6,77-79 
De fato, São Pedro afirma: 'ela não foi retida no inferno'. Com efeito, Pedro não coloca a questão que a natureza que é absolutamente inalcançável e inacessível, isto é, a natureza divina do Unigênito, tenha regressado dos abismos subterrâneos. Porque não haveria de assombra-se se o Lógos de Deus não permaneceu nos infernos, ele que por sua atividade e natureza divina, prodigiosamente, inconcebivelmente, tudo enche, habita em tudo. A divindade está por cima de toda localização, limite e tamanho mensurável, sem poder ser contida por nada. O paradoxo, do qual ninguém pode deixar de admirar-se, é que um corpo, que era por natureza corruptível, tinha sido revivido, pois estava unido

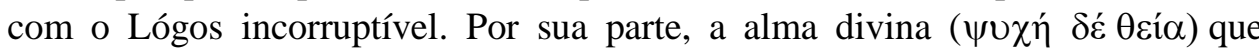
recebeu o concurso e a união junto com o Lógos, desce para residir no Hades, usando da virtude e potência que pertencem a Deus, se mostrou também aos espíritos que ali estavam ${ }^{361}$

Último Padre da Igreja Oriental, São João de Damasco, dedica ao Descensus o cap. 29 do livro III de sua obra De fide ortodoxa. Após ter refutado os principais erros cristológicos (monofisismo, monoenergismo e monotelismo) e afirmado, num contexto histórico-salvífico, a doutrina católica sobre Jesus (união hipostática, communicatio idiomatum, duas vontades, etc) o Damasceno afirma que "a alma deificada desceu aos infernos, e assim o Sol da justiça raiou para os que habitavam sob a terra, assim (desceu) para iluminar também aqueles que debaixo da terra sentavam-se nas trevas e na sombra da morte" 362

(SChr 434 p. 248); Carta XVII 4,93-94 (SChr 434 p. 292). A concepção do Descensus predominante nas cartas é a vitória sobre potências infernais, ainda que não esteja ausente o tema da pregação (cf. Carta I, 6,168-169, SChr 372, p. 185; Carta XIX; PG 77, 836C).

${ }^{361}$ De Incarnatione Unigeniti 692b-694a, SChr 97, 235. O mesmo tema pode ser encontrado, em clara referência à polêmica anti-apolinarista, no já citado Fragmentum in Epistolam I Petri: indo em alma, pregou aos espíritos no Hades, como alma tratou as almas. Os que guardavam o inferno, vendo-o, tremeram, romperam-se as antigas portas e as trancas primitivas se abriram. (PG 74,1013C).

${ }^{362}$ PG 94, 1101. 
Quanto ao Ocidente, a afirmação da descida da alma de Cristo aos infernos remonta a Tertuliano, o qual, em sua fase católica, afirmava que com a alma de Cristo subiram aos céus as almas dos justos ${ }^{363}$ (após se tornar montanista, Tertuliano limitou esta ascensão aos mártires, os únicos que estariam desfrutando do Paraíso ${ }^{364}$ ). Após as controvérsias apolinaristas, a mesma doutrina é atestada por Fulgêncio de Ruspe ${ }^{365}$ e pelo Papa Hormisdas, na Carta Inter ea quae (26 de março de 521) ao Imperador Justino

Em coerência com o querer nascer homem, foi sepultado, em coerência como ser semelhante ao Pai, ressuscitou: sofredor de feridas e salvador dos sofredores, contado entre os defuntos e vivificador dos moribundos, descendo aos infernos e não se afastando do seio do Pai. Assim, por força singular e admirável poder, retornou também logo a alma que pela [nossa] condição comum tinha entregue 366.

O mesmo tema aparece, por fim, na Explanação sobre o Cântico dos Cânticos de Apônio ${ }^{367}$ : "Esta é sem dúvida a única alma, a rainha das rainhas, que assumiu e trouxe o Verbo de Deus de modo exemplar, por meio da qual ele abalou o inferno e libertou as almas que estavam presas" 368 .

\footnotetext{
${ }^{363}$ Tertuliano, De anima 55, PL 2, 742-743.

${ }^{364}$ Tertuliano, De resurrectione 43,11, PL 2, 742-743.

365 (...) o mesmo que foi feito Deus-homem (Jo 1,14) foi suspenso na cruz, e o mesmo que foi feito Deus-homem (Jo 1,14) estava no sepulcro, e o mesmo que foi feito Deus-homem (Jo 1,14) ressuscitou dos infernos no terceiro dia. Mas, no sepulcro, o mesmo Deus estava somente segundo a carne, e no inferno desce somente segundo a alma. Esta retornando dos infernos à carne no terceiro dia, o mesmo Deus ressuscitou do túmulo segundo a carne pela qual estava no sepulcro. E quarenta dias depois da ressurreição, o mesmo que foi feito Deus (Jo 1,14), subindo aos céus, sentou-se a direita de Deus, de onde virá no fim do século para julgar os vivos e os mortos FULGENCIO DE RUSPIO, De fide ad Petrum, 11 in: GOUNELLE, R. La descente du Christ aux enfers. 2004, PP. 351-352.

${ }^{366}$ Epistola 79 PL 63 513D.

${ }^{367}$ Com o nome de Apônio, considerado como romano, foi transmitida a Expositio in Canticum Canticorum, segundo a opinião comum escrita entre o a. 405 e 451 na Itália, provavelmente em Roma. Inspirado por modelos anteriores (Orígenes, Ps.-Hipólito) e fundamentado numa discreta cultura teológica e filosófica, este comentário merece ser estudado tanto em vista da história da exegese (conceito de história da salvação - visão espiritual da união entre Cristo e a Alma), como pelo que diz respeito à sua cristologia, segundo a qual a alma de Jesus, unida definitivamente ao Verbo no momento da cruz, conseguiu lugar de destaque. A sua influência, porém, talvez não tenha sido relevante. De qualquer modo, Gregório Magno e Beda o Venerável a conheciam e no séc. IX foi retomada na forma de doze homilias. (DPAC p. 135-136).

368 APONIUS, Canticum Canticorum Explanationis libri duodecim, IX, PLS 1,962.
} 


\section{5. - A sistematização da doutrina nos Símbolos de fé.}

Ainda que fórmulas doutrinas estejam presentes no Novo Testamento $^{369}$ e na literatura cristã antiga ${ }^{370}$, o gênero "Símbolos de fé" demorou mais tempo a se desenvolver. Utilizados nos ritos batismais, os Símbolos desenvolveram-se das formas interrogativas (usadas na cerimônia do batismo) para as fórmulas declarativas que os catecúmenos deveriam recitar no período da instrução, estas particularmente influenciadas pela Regula fidei ${ }^{371}$. "No Ocidente, sua forma particular, desenvolvida na igreja de Roma (o antigo Símbolo romano, conhecido pelos estudiosos como R) por volta de 330, redigido originalmente numa fórmula grega do princípio do séc. II, tornou-se o modelo de todos os símbolos ocidentais desse tipo" ${ }^{\text {372 }}$. Neste, como se pode constatar nas antigas versões de Hipólito de Roma ${ }^{373}$ e de Marcelo de Ancira $^{374}$, não se faz menção da descida de Cristo aos infernos.

Foi no Oriente, num período particularmente fecundo ao desenvolvimento dos Símbolos (período da recepção do $1^{\circ}$ Concílio Niceno), que o tema da descida de Cristo aos infernos foi introduzido numa profissão de fé. Para entender o alcance de tal proposição, faze-se necessário um breve resumo da situação da época.

\subsection{1 - Os Símbolos filo-arianos.}

O Concílio Niceno foi seguido por intermináveis discussões sinodais, nas quais os grupos se dividiam, sendo uns acusados de arianismo (Eusébio de Nicomédia e seus partidários) e outros de sabelianismo (Marcelo de Ancira e, por

${ }^{369}$ Por ex. Rm 1,3-4; 4,24-25; 1Cor 8,6; 1Tm 2,5; 3,16; 1Pd 3,18.

${ }^{370}$ Por ex nas cartas de Inácio de Antioquia (Efésios 18,2; Tralianos 9; Esmirnenses 1,1-2) ou de Policarpo de Esmirna (Filipenses 2,1).

371 Definida por R.P.C. Hanson como um "sumário genérico da fé cristã tal como era ensinada e pregada nas igrejas daqueles escritores que dela falam, resumida em termos ligeiramente diversificados de acordo com as predileções do escritor, mas contendo em todo lugar a mesma doutrina substancial” DI BERARDINO, A. (Org). Dicionário Patrístico e de Antiguidades Cristãs, 1999 , p 322.

372 Idem.

373 /.../ e foi crucificado sob Pôncio Pilatos, e morreu, e foi sepultado, e ao terceiro dia ressuscitou vivo dos mortos. (DHü 10).

374 /.../ que sob Pôncio Pilatos foi crucificado e sepultado, e ao terceiro dia ressurgiu dos mortos (DHü 11). 
sua ligação com este, também Atanásio de Alexandria). O problema não deixava de ter sua origem no próprio Concílio, pois, ao afirmar ser o Filho

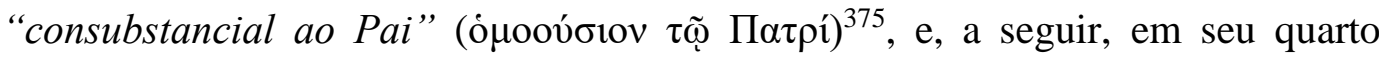
anatematismo, identificar ousia e hypostais ${ }^{376}$, criou uma confusão terminológica que dificultava a aceitação da fórmula homoousios ${ }^{377}$.

Ofendidos com a reabilitação de Marcelo Ancira pelo Papa Júlio, no Concílio reunido em Antioquia para a dedicação da "igreja de ouro" (verão de 341), os bispos, que reabilitaram Ario, mas rejeitavam energicamente serem $\operatorname{arianos}^{378}$, promulgaram "um texto que, de um lado rejeitava o arianismo radical, mas, por outro, prescindia da fórmula nicena e falava em sentido anti-modalístico das três hipóstases da Trindade"379. O texto, claramente oposto a Marcelo de Ancira $^{380}$, não trazia referência à descida de Cristo aos infernos.

Em resposta, a pedido dos bispos ocidentais, o imperador ocidental Constante convenceu seu irmão Constâncio, imperador oriental, a reunir no outono de 342 (ou 343) um concílio em Sérdica (atual Sófia, Bulgária) na fronteira dos dois impérios, para resolver definitivamente a questão da deposição de Atanásio, Marcelo e outros, bem como a questão de fé subjacente ${ }^{381}$. O resultado foi desastroso: os orientais, além de responderam fracamente à convocação, exigiram que não participassem do concílio os bispos depostos e

\section{${ }^{375}$ DHü 125.}

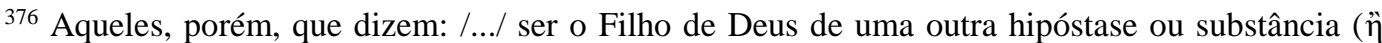

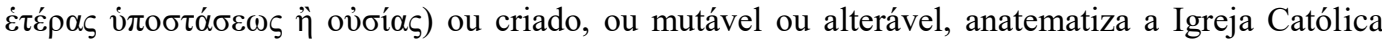
(DHü 126).

377 Se il Padre e il Figlio erano «della stessa sostanza» (ousia) sembravano essere anche «identici» e questo tanto più che i niceni in senso stretto, come Osio di Dordova, parlavano anche di una hypostasis di Padre e Figlio. SCHATZ, K.; Storia dei concili. La Chiesa nei suoi punti focali, Edizioni Dehoniane, Bologna, 1999, p. 34.

${ }^{378}$ Siendo obispos, ¿como iban a rebajarse a seguir un sacerdote?. KELLY, J.N. D.; Primitivos Credos Cristianos, 1980, p. 317.

${ }^{379}$ SCHATZ, op. cit. 34.

${ }^{380}$ Citado por Atanásio PG 26,724. Es cierto que el término homooúsios no aparece en él y, en este sentido, no refleja en plenitud la teología nicena. Pero el arrianismo en sentido estricto se excluye con toda intención al afirmar que el Hijo existió desde antes de todos los tiempos, coexistiendo con el Padre. Al mismo tiempo, los obispos aprovecharon la ocasión para atacar veladamente a su tan odiado Marcelo de Ancira, contra el que va la afirmación de que el Hijo permanece para siempre rey y Dios. Porque una de las características de la doctrina de Marcelo era que el señorío de Cristo acabaría, de acuerdo con lo que Pablo parece decir con aquello de: «Pues él tiene que reinar hasta que haya puesto todos sus enemigos bajo sus pies» (1 Cor 15,25). Para Marcelo se volvería a la mónada divina, la cual en la revelación se había convirtiendo sucesivamente en tríada, pero mediante el proceso inverso volvería a la unidad original, con lo que Dios sería todo en todo. Por tanto, al excluir los extremos representados respectivamente por Arrio y Marcelo, el credo elegía la vía media, preferida por la mayoría de los eclesiásticos. KELLY, op. cit. 318-319.

${ }^{381}$ Sobre o Concílio de Sérdica, ver KELLY, op. cit. pp. 328-333. 
acabaram se retirando em bloco, invocando a necessidade de felicitar o imperador Constâncio por sua vitória sobre os persas. Antes disso, porém, formaram um contra-assembléia, que redigiu uma profissão de fé moderada, de acento antisabeliano (contra Marcelo de Ancira), na qual também não há menção da descida de Cristo à morada dos mortos.

Os ocidentais, por sua vez, reagiram reabilitando Atanásio, Marcelo e Asclépio de Gaza, excomungando Valente de Mursa e Ursácio de Singidunum ("duas víboras geradas pela áspide ariana”) e redigindo uma profissão de fé, composta provavelmente por Ósio de Córdoba e por Protógenes, o bispo local. Esta, mesmo insistindo na diferença das Pessoas ${ }^{382}$, afirmava energicamente a unidade hipostática, em termos tão extremos e provocadores ${ }^{383}$, que só poderiam piorar ainda mais a situação.

Continuou, pois, por bastante tempo a controvérsia: os ocidentais com sua insistência na unidade de Deus e sua tendência em favor de Marcelo (tanto Santo Atanásio como o Ocidente em geral, não tiveram os olhos suficientemente abertos para ver os perigos da teologia marcelianista), que aos orientais soava como sabelianismo. Os orientais, por sua vez, notadamente influenciados pelo origenismo, consideravam a Divindade como três hipóstases ordenadas hierarquicamente, o que o Ocidente via como um triteísmo incipiente, não cessando de condená-lo, ainda que sem razão, como arianismo. Foi neste contexto que,

em 357, alguns bispos - entre os quais se destacavam Valente de Mursa e Ursácio de Singidunum - se reuniram em Sírmio, onde publicaram uma fórmula de fé que passou a ficar conhecida, na tradição nicena, como blasphemia Sirmiensis. Ela não fazia referência às teses dos anomeus, e condenava o uso tanto de homoousios quanto de homoiousios (homoioúsios, 'semelhante na substância') sublinhando a inferioridade do Filho em relação ao Pai (Hilário de Poitiers, De syn. 11) ${ }^{384}$

\footnotetext{
${ }^{382}$ We do not say that the Father is Son, nor that the Son is Father; but that the Father is Father, and the Son of the Father Son. (Ibid.)

${ }^{383}$ La doctrina que se defiende positivamente es la de que no hay sino una hipóstasis divina, «la que los mismos herejes denominan ousía». No hay más que un solo Dios, una divinidad de Padre, Hijo y Espíritu Santo, una hipóstasis. La hipóstasis del Hijo es la misma y idéntica que la del Padre. Con todo, el Padre y el Hijo no son idénticos. KELLY, op. cit. 331-332

384 PERRONE, L. De Nicéia a Calcedônia, in. ALBERIGO, G.; História dos Concílios Ecumênicos, 1995, 51.
} 


\subsection{2 - O Símbolo de Sírmio.}

Foi no contexto destas controvérsias, que encontramos a mais antiga menção à descida de Cristo aos infernos em um Símbolo, no Símbolo do $4^{o}$ Sínodo de Sírmio (ano 359), de tendências semi-arianas ${ }^{385}$, cujo teor nos é reportado por Santo Atanásio de Alexandria ${ }^{386}$. Elaborado na corte imperial de Constâncio II (e a pedido deste), por representantes de diversas tendências teológicas, tinham como propósito servir de base sobre a qual se pretendia obter a unidade da Igreja, dividida no Sínodo de Sérdica. Deveria, pois, ser apresentado aos delegados ocidentais que se reuniram em Rímini e aos orientais, em Selêucida.

A propósito de nosso tema o Símbolo afirmava: "que foi crucificado e que

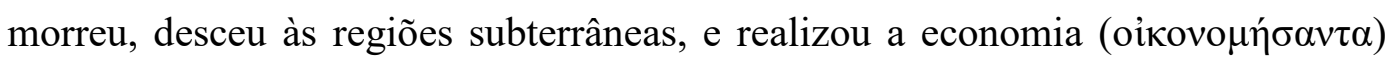
com os que ali estavam; que o vendo os guardiões do Hades tremeram (Jó $38,17 \mathrm{~b}$ ), e que ressuscitou dentre os mortos ao terceiro dia" ${ }^{387}$.

A ausência de um artigo referente ao sepultamente de Jesus fez com que se pensasse que a menção ao Descensus fosse, no Símbolo de Sírmio, um mero substituto do sepultamento. A menção, porém, da "economia" realizada pelo Senhor nos infernos e do temor de seus guardiões não permite, porém, tal conclusão.

A mencionada "economia" é o projeto global da encarnação, segundo o qual Cristo deve se dirigir a todo o homem, incluindo aqueles que o esperavam nos infernos (tema desenvolvido na interpretação do Descensus como pregação

\footnotetext{
385 No exílio o Papa Libério subscreveu o Símbolo composto pelo sínodo semi-ariano e excomungou Atanásio, o defensor da fé. Disto dão testemunho cartas do mesmo Libério conservadas entre fragmentos da obra histórica Adversus Valentem et Ursacium de Hilário de Poitiers, cuja autenticidade no passado foi impugnada sem razão. Coloca-se assim, a questão da ortodoxia do Papa Libério. As fórmulas de fé por ele aceitas evitam o conceito niceno de homousios. Trata-se sobretudo da primeira fórmula sirmiense, definida no II Sínodo de Sírmio (Panônia Inferior), em 351, contra Paulo Samosata e Fortino, fórmula que Libério, no exílio em Beréia, em 357, teve de subscrever. Esta fórmula foi benignamente interpretada no sentido da ortodoxia por Hilário de Poitiers, severo crítico de Libério: de Synodis, 39-62. Muito provavelmente, Libério levado em 358 para Sírmio, subscreveu também a $3^{\text {a }}$ fórmula sirmiense, estabelecida no IV Sínodo (depois da Páscoa de 358). Esta é composta da supracitada 1 formula sirmiense, da 2 fórmula do Sínodo - também semi-ariano - de Antioquia (no período da festa da Encênia de 341) e dos anatematismos extraídos dos 19 artigos do sínodo semi-ariano de Ancira (antes da Páscoa de 358) pelo IV Sínodo de Sírmio (omitidos os cânones 1-5,18 e 19, particularmente suspeitos de heresia). (DHü p. 57).

${ }^{386}$ De Synodis 8,5 PG 26,692-693.

${ }^{387}$ O texto nos é transmitido por Sócrates, História Eclesiástica II,37,20 (PG 67, 305)
} 
aos mortos). A menção ao temor das potências infernais é um tema bastante freqüente nas descrições da descida de Cristo aos infernos ${ }^{388}$, fazendo parte da interpretação do Descensus como vitória sobre os poderes infernais. Desse modo, o Símbolo de Sírmio, em breves palavras, retoma os principais motivos da interpretação soteriológica do descensus ad infera ${ }^{389}$.

\subsection{3 - O Símbolo de Nicéia.}

Tendo sido apresentada aos 400 representantes ocidentais, reunidos em Rímini, a blasphemia Sirmiensis foi imediatamente rejeitada por estes, que também condenaram Valente de Múrcia (subordinacionista) e afirmaram a necessidade de se ater à fórmula do ano 325 , definida em Nicéia (entendida como teologia de uma única hypóstasis). Não sendo possível chegar a um consenso, cada uma das partes enviou uma delegação junto ao imperador. Enquanto aguardavam por estes em Nicéia, pressionados por Valente, "os delegados ocidentais da maioria - que rejeitara o texto de Sírmio - revisaram as decisões do Sínodo que os enviara. Em 10 de outubro de 359, anularam a condenação de Valente e de seus amigos, e assinaram uma forma modificada do símbolo de Sírmio" ${ }^{390}$, conhecida tradicionalmente como Símbolo de Nicéia.

No que se refere à descida de Jesus aos infernos, o Símbolo professava: "foi suspenso na cruz, morreu e foi sepultado, desceu às regiões subterrâneas, diante do qual o inferno tremeu e subiu dos mortos no terceiro dia" ${ }^{391}$.

\footnotetext{
${ }^{388}$ Como ex. se pode citar o Fragmentum in Epistolam I Petri de Cirilo de Jerusalém, que retoma, praticamente, as mesmas expressões do Símbolo de Sírmio: Os que guardavam o inferno, vendo-o, tremeram, romperam-se as antigas portas e as trancas primitivas se abriram. O Unigênito falou com suma autoridade aos espíritos simpatizantes pronunciando a palavra da economia

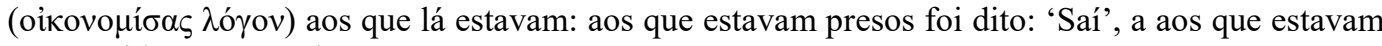
na escuridão: "Mostrai-vos'. (PG 74, 1013C).

${ }^{389} \mathrm{~L}$ 'interpretation du symbole de Sirmium à la lumière des autres textes qui associent comme lui le motif de l'économie' et $\mathrm{Jb} 38,17 \mathrm{~b}$ à notre théologoumène permettent donc de supposer que les rédacteurs de cette formule de foi ont voulu décrire la venue du Fils de Dieu dans le monde infernal en ces termes: le Christ s'est rendu parmi les morts afin de réalizer le but de l'incarnation, tel qu'il était voulu par le Père; le déploiement immédiat de sa puissance a effrayé les puissances infernales. GOUNELLE, R.; La descente du Christ aus enfers, 2000,. p. 291).

${ }^{390}$ GOUNELLE, R.; op. cit. p. 295.

${ }^{391} \mathrm{O}$ texto nos é transmitido por Teodoreto de Ciro, História Eclesiástica II,21,4 (cf. em inglês: http://www.ccel.org/ccel/schaff/npnf203.iv.viii.ii.xvi.html 
Como se pode perceber na comparação dos textos, ainda que o Símbolo de Nicéia mantenha a afirmação fundamental da descida de Jesus às regiões subterrâneas, além da exclusão de toda referência à "economia" realizada pelo Senhor no Hades, a mudança em relação ao tremor das potências infernais faz com que se torne imperceptível a referência à passagem bíblica que o fundamentava o texto, Jó 38,17. Com efeito, alterou-se o sujeito da frase, mudando de "guardiões do Hades" para o próprio "Hades" e omitiu-se, toda referência à visão do Senhor. Dissociou-se, assim, o temor causado nos poderes infernais da visita do Senhor, associando-o ao temor causado à criação pela sua morte na cruz

O inferno, com efeito, aparece menos como uma força que Cristo deve vencer, que como um lugar que treme por sua descida, da mesma maneira que as outras partes do mundo criado; esse terror de toda criação não está diretamente ligada à vinda do Filho de Deus do mundo infernal, mas à sua morte, enquanto que o tremor dos porteiros se realizou pela descida aos infernos. A tradição do medo da morte e aquela do medo dos porteiros não se sobrepõem, mas correspondem a momentos diferentes da história da salvação ${ }^{392}$. /.../ Revisando a quarta fórmula de Sirmium, os redatores do símbolo de Nicéia não se contentam em fazer modificações estilísticas. Pela supressão do motivo da 'economia' e pela ocultação da citação de Jó $38,17 \mathrm{~b}$, foi introduzido na confissão de fé um enunciado mais ambíguo, que poderia imediatamente ser interpretado fora do contexto da descida aos infernos se não aparecesse depois à menção 'desceu as regiões subterrâneas'. Que se refira diretamente ou não, o medo do mundo infernal não parece apresentar um papel preponderante na vitória de Cristo sobre as forças infernais: ele não causou a derrota; anunciou-a - ela ocorre quando o Filho de Deus está na cruz - onde a sanciona ${ }^{393}$

http://www.documentacatholicaomnia.eu/04z/z_0393-

0466_Theodoretus_Cyrrhi_Episcopus_Historia_Ecclesiastica_EN.doc.html

${ }^{392}$ GOUNELLE, R.; op. cit. p 289.

393 Ibid. p. 300 


\subsection{4 - O Símbolo de Constantinopla.}

O tema da descida de Cristo aos infernos não aparece na profissão de fé proposta por Acácio de Cesaréia no Sínodo de Selêucida (final do ano 359) ${ }^{394}$. "Obviamente, nosso teologúmeno parece ter sido ligado às controvérsias entre os homeous e partidários de uma única hipóstese - controvérsias que apresentaram um papel importante nas negociações que se realizaram em Sírmio e em Nicéia como aos debates entre os neo-arianos e homeouseanos em Selêucida" ${ }^{395}$. Como não chegassem a um acordo, tanto os partidários de Acácio como os homeousianos enviaram embaixadas ao imperador, que se encontrava em Constantinopla.

$\mathrm{Na}$ profissão de fé elaborada pelo Concílio que se reuniu em Constantinopla, em janeiro de 360, nosso tema volta a aparecer: "foi crucificado, morto e sepultado, desceu as regiões subterrâneas, diante do qual o inferno tremeu, ressuscitou dos mortos no terceiro dia" ${ }^{\text {396 }}$. Como se pode perceber com a comparação dos textos, a fórmula retomou a citação de Jó 38,17b (versão dos Setenta) ${ }^{397}$ como base escriturística para a afirmação da descida de Cristo aos infernos, empregada anteriormente em Sírmio, que o Sínodo de Nicéia havia deixado de lado.

Como vimos, os primeiros Símbolos a fazerem menção da descida de Cristo aos infernos foram os de tendências arianas. Nestes também, o tema não ocupava lugar de destaque, sendo, muitas vezes, apenas mencionado junto aos temas da paixão e ressurreição.

Isso, porém, não diminui a importância de nosso tema. Cabe, primeiramente, lembrar que sua ausência em um Símbolo não equivale de modo algum à ignorância ou, menos ainda, à negação dessa verdade de fé por parte da Igreja que o utilizava. Assim, por ex., não encontramos a afirmação do Descensus

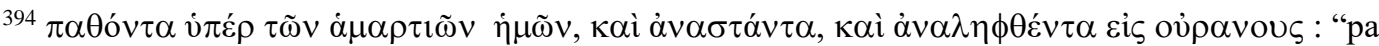
deceu pelos nossos pecados, ressuscitou e foi levado aos céus. (Sócrates de Constantinopla, História Eclesiástica II, 40, 2; PG 67, 345).

395 GOUNELLE, R.; op. cit. p. 301.

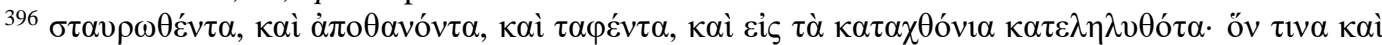

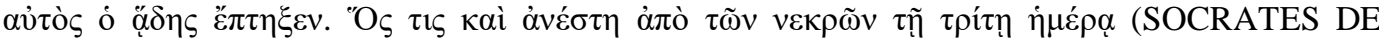
CONSTANTINOPLA, História Eclesiástica II, 40, 2; PG 67, 355).

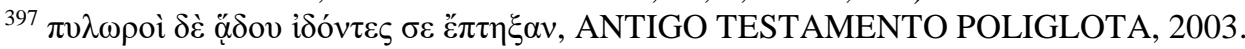


na profissão de fé da Igreja de Hipona: Santo Agostinho, no Sermão Guelferbytanus, ao comentar o Símbolo, passa diretamente do sepultamento à ressurreiçãa ${ }^{398}$. Isto não significa que ele ou sua Igreja desconhecessem ou negassem o Descensus, como se percebe perfeitamente em sua Carta a Evódio: "Quem, pois, senão um infiel, negará que Cristo esteve nos infernos?"399. O mesmo se pode dizer em relação à Igreja de Cartago: mesmo não figurando em seu Símbolo, o tema aparece nas explicações de seu bispo Quodvultdeus ${ }^{400}$.

Também, a ausência de discussões é indicativa de que todos os lados em oposição admitiam pacificamente que o Senhor desceu aos infernos, mesmo quando divergiam quanto ao seu conteúdo e interpretação.

Cabe perguntar a razão do particular interesse dos arianos (e semi-arianos) no tema da descida de Cristo aos infernos. A resposta parece estar na interpretação que davam da doutrina.

Os teólogos arianos parecem ter citado a descida do Filho de Deus nas regiões subterrâneas afim de afirmar sua ausência junto ao Pai, e ter utilizado este motivo para explicar o medo que Cristo sofreu diante da morte. O arianismo parece ter dado certa importância ao da vinda do Filho de Deus ao mundo infernal como parte de suas elaborações dogmáticas, provocando, por sua vez, o labor teológico de seus adversários ${ }^{401}$.

\footnotetext{
398 AGOSTINHO, Sermo 213, 3; PL 38, 1061-1062

${ }^{399} \mathrm{Ib}$, Epístola 164,3; PL 33, 710.

${ }^{400}$ Quodvultdeus Sermo 3: De Symbolo, III.6.9-10 (CCL 60,359), o texto do Símbolo pode ser encontrado em DHü 22.

${ }^{401}$ GOUNELLE, op. cit. 142.
} 


\subsection{5 - Os Símbolos católicos - O Símbolo de Aquiléia}

O tema da descida de Jesus aos infernos parece ter ocupado lugar de destaque na Igreja de Aquiléia, norte da Itália, como se deduz das pregações pascais de seu bispo São Cromácio ${ }^{402}$. Tal importância aparece também refletida no fato do Símbolo daquela Igreja, conforme atesta o monge-teólogo Tirânio Rufino (em escrito do ano 404), ser o mais antigo Símbolo ocidental, não ariano, que faz menção da descida do Senhor aos infernos: "crucificado sob Pôncio Pilatos e sepultado, desceu aos infernos, ao terceiro dia ressuscitou dos mortos" $" 403$.

Em sua exposição, Rufino justifica o fato da profissão de fé de sua Igreja trazer um artigo que não estava presente nem no Símbolo da Igreja Romana, nem nos Símbolos orientais, dizendo que o sentido da expressão se encontrava nas palavras "foi sepultado", presente nos demais símbolos ${ }^{404}$. Tal justificativa, que pretendia prevenir qualquer acusação contra a Igreja de Aquiléia, em área tão delicada, como a profissão da fé, é contrariada pela exposição que o mesmo Rufino fez a seguir.

Com efeito, pretendendo provar pelas Escrituras o artigo de fé professado, Rufino referiu-se a diversas passagens que não guardam relação direta com o sepultamento do Senhor: "mas que também desceu ao inferno foi de modo evidente pronunciado profetizado nos Salmos, onde se diz" (segue a citação dos $\mathrm{Sl}$ 21,16; 29,10; 68,3, bem como Mt 11,3; 1Pd 3,18 e, para falar da ação de Cristo nos infernos, S1 35,10; S1 29,4) ${ }^{405}$. Assim, pois, a afirmação do descensus ad infera para a Igreja de Aquiléia é um evidente conteúdo soteriológico, não sendo mero sinônimo do sepultamento de Jesus.

O que afirmamos é indiretamente comprovado por um símbolo de origem desconhecida, com probabilidade de vir do norte da Itália (região de Aquiléia), no

\footnotetext{
402 Sermo 16, (Sermo I in nocte magna, SChr 154, 262-267), Sermo 24, 5 (SChr 164, 76-77).

403 Commentarius in Symbolum Apostolorum 14, PL 21,352.

${ }^{404}$ Sciendum sane est, quod in Ecclesia Romanæ Symbolum non habetur additum, descendit ad infera: sed neque in Orientis Ecclesiis habetur hic sermo: vis tamen verbi eadem videtur esse in eo, quod sepultus dicitur. (Ibid. PL 21, 356).

${ }^{405}$ Ibid. 28, PL 31,363.
} 
qual o conteúdo soteriológico do Descensus aparece de modo mais explícito, ao se afirmar que o Senhor "desceu ao inferno; pisoteou o aguilhão da morte"406.

\subsection{6 - O Símbolo Apostólico.}

Aos dez dias da Ascensão, estando reunidos os discípulos por medo dos judeus, o Senhor lhes enviou Paráclito prometido. À sua vinda, se inflamaram como ferro em brasa, e, cheios do conhecimento de todas as línguas, compuseram o Símbolo. Pedro disse: 'Creio em Deus Pai todo-poderoso... Criador do céu e da terra'. André disse: 'e em Jesus Cristo, seu Filho... nosso único Senhor'... Tiago disse: 'Que foi concebido do Espírito Santo... nasceu de Maria Virgem'... João disse: 'Padeceu sob Pôncio Pilatos..., foi crucificado, morto e sepultado'... Tomé disse: 'Desceu aos infernos... ao terceiro dia ressuscitou dos mortos'... Tiago disse: 'Subiu aos céus... está sentado à direita de Deus Pai todo-poderoso'... Felipe disse: 'donde há de vir julgar os vivos e os mortos'... Bartolomeu disse: 'Creio no Espírito Santo'... Mateus disse: 'e na Santa Igreja Católica..., na comunhão dos santos'... Simão disse: 'No perdão dos pecados'... Tadeu disse: 'na ressurreição da carne'... Matias disse: 'na vida eterna' ${ }^{407}$.

Uma ingênua lenda sobre a composição do Símbolo apostólico ${ }^{408}$, atestada por um sermão atribuído a Santo Agostinho, pretendia dar autoridade apostólica ao assim chamado Textus receptus (T), uma versão ampliada do antigo Símbolo batismal da Igreja romana ${ }^{409}$. Nele, se atribui ao apóstolo Tomé a composição do artigo que afirma a descida do Senhor aos infernos ${ }^{410}$. De fato, se o antigo Símbolo romano (conhecido como R) não continha a afirmação do descensus ad ínfera, através desse novo Símbolo, logo chamado apostólico, ele passou definitivamente a fazer parte do patrimônio de fé cristã. Com efeito, se os orientais contestaram sua origem apostólica, no Concílio de Florença (Ferrara, ano 1438), afirmando nunca ter tido notícia de tal tradição, o Símbolo Apostólico,

$406 / . . . /$ il a été crucifié; il a été enseveli; il a foule aux pieds l'aiguillon de la mort, e le troisième jour il est ressuscité... (Fides sancti Hieronymi, in GOUNELLE, R., La descente du Christ aus enfers., 2000, p. 338.

407 (Pseudo) Agostinho, Sermão 240,1, De Symbolo, PL 39, 2189.

408 A lenda é narrada também por Tirano Rufino, Commentarius in Symbolum Apostolorum, 2 (PL $21,337)$.

${ }^{409}$ O Símbolo Apostólico, tal como o conhecemos hoje, é uma versão ligeiramente modificada de R (é indicado como T), que provavelmente vinha do sudoeste da França (Septimânia) e foi largamente adotado na Europa ocidental antes de ser finalmente aceito pela conservadora Igreja romana, por volta de 800 a 1000 . A legenda de que cada um dos apóstolos teria formulado um artigo deste credo era muito aceita até o fim do séc. IV. DI BERARDINO, A. (Org). Dicionário Patrístico e de Antiguidades Cristãs, 1999, p 322.

${ }^{410} \mathrm{O}$ sermão acrescenta pequeno comentário explicativo a cada artigo, que omitimos em nossa tradução. $\mathrm{O}$ texto completo referente ao artigo em questão diz: Thomas dixit, Descendit ad inferna: id est, in anima comitante divinitatem, corpore vero in sepulcro quiescente [Pseudo]. AGOSTINHO, Sermão 240,1, De Symbolo, PL 39, 2189). 
mais tarde acabou se impondo como profissão de fé reconhecida pela maioria das Igrejas e Comunidades eclesiais cristãs ${ }^{411}$.

\subsection{7 - O Símbolo (pseudo-) Atanasiano.}

O último símbolo ocidental (do qual temos notícia) a mencionar brevemente a descida de Cristo aos infernos, conhecido como Quicumque (vult). Sua atribuição a Santo Atanásio de Alexandria (atestada em documentos do séc. VIII) não é mais, praticamente, aceita por nenhum estudioso do tema. Acredita-se que tenha sido composto entre os anos 430 a 500, no sul da Gália, possivelmente em Arles. Adquiriu, junto aos Símbolos apostólico e Niceno grande importância, sendo usado na liturgia, particularmente no Rito De exorcizandis obsessis, a daemonio do antigo Rituale Romanum ${ }^{412}$.

Em relação ao nosso tema, o Símbolo Quicumque, diz apenas: "Ele padeceu pela nossa salvação, desceu aos infernos (descendit [discendit] ad inferos), subiu aos céus"413.

Não deixa de ser significativo que o assim chamado "Credo do Povo de Deus", composto pelo Papa Paulo VI no encerramento do “Ano da Fé" (1968, $19^{\circ}$ centenário XIX do martírio de S. Pedro e S. Paulo) para ser uma profissão de fé "suficientemente explícita e completa para satisfazer, de maneira adequada, à necessidade de luz que angustia a tantos fiéis e a todos aqueles que no mundo buscam a Verdade", não traga menção alguma à descida de Cristo à morada dos mortos: "morreu por nós pregado na Cruz, trazendo-nos a salvação pelo seu Sangue redentor. Foi sepultado e ressuscitou ao terceiro dia pelo seu próprio poder, elevando-nos por esta sua ressurreição a participarmos da vida divina que é a graça" ${ }^{414}$. A omissão pode ser devida apenas ao fato do Credo do Povo de Deus

\footnotetext{
${ }^{411}$ KELLY, J.N. D.; Primitivos Credos Cristianos, 1980, pp. 19 e 435-436.

412 Rituale Romanum Pauli Pontificis Maximi jussus editum aliocumque pontificium cura recognitum atque auuctoritate SSmi. D.N. Pii Papæ XI ad normam Codis Iuris Canonicum accommodatum, Editio justa typicam Vaticanam, Roma, 1925, pp. 276-277.

${ }^{413}$ DHü 75-76.

414 Paulo VI, Homilia em 30 de junho de 1968, Conclusão do "Ano da Fé", http://www.vatican.va/holy_father/paul_vi/motu_proprio/documents/hf_p-vi_motuproprio_19680630_credo_po.html
} 
seguir, neste ponto o Símbolo Niceno-constantinopolitano (que também não traz referência alguma ao Descensus), ou pode ser indicativa da dificuldade que tem o homem moderno para entender um artigo de fé, que utiliza uma representação cosmológica tão diversa da que possuímos.

\section{6 - O testemunho litúrgico (a lex orandi)}

O tema da descida do Senhor aos infernos não ocupa grande papel na liturgia. Ainda que os mistérios do Senhor, particularmente aqueles referentes à Paixão e Ressurreição, sejam um tema obrigatoriamente presente nas orações Eucarísticas, o tema do Descensus raramente encontra-se presente nelas. De fato, das muitas Anáforas existentes, nas tradições orientais e ocidentais, conseguimos encontrar menção do tema nas que seguem:

- A Anáfora de Hipólito, datada em torno de 218, é uma das mais antigas. Não há Sanctus, mas encontramos outras partes essenciais da grande oração eucarística: ação de graças, narrativa da instituição, anamnese, epíclese e a doxologia. A anáfora faz uma introdução da doutrina soteriológica da descida na liturgia. Podemos encontrar, também, uma relação entre a celebração eucarística (como memorial da morte do Senhor) com referência a descida de Cristo ${ }^{415}$.

- A Anáfora grega de São Basílio de Cesaréia: "Ele mesmo Se entregou como preço da morte, na qual estávamos retidos, vendidos pelo pecado, e desceu aos infernos, passando pela cruz, para levar tudo à sua plenitude e destruir as cadeias da morte" $" 416$.

\footnotetext{
${ }^{415}$ Nous te rendons grâces, ô Dieu, par ton Enfant bien-aimé Jésus-Christ, que tu nous as envoyé en ces derniers temps (comme) sauveur, rédempteur et messager de ton dessein, qui lui est Verbe inséparable par qui tu as crée et que, dans ton bon plaisir, tu as envoyé du ciel dans le sein d'une vierge et qui ayant été conçu, s'est incarné et s'est manifesté comme ton Fils, né de l'Esprit-Saint et de la Vierge. C'est lui qui, accomplissant ta volonté et t'acquérant un peuple saint, a étendu les mains tandis qu'il souffrait pour délivrer de la souffrance ceux qui ont confiance en toi. Tandis qu'il se livrait à la souffrance volontaire, pour détruire la mort et rompre les chaînes du diable, fouler aux pieds l'enfer, amener les justes à la lumière, fixer la règle (de foi ?) et manifester la résurrection, prenant du pain, il te rendit grâces et dit : Prenez, mangez, ceci est mon corps qui est rompu pour vous. HIPPOLYTE DE ROME, La Tradition Apostolique, 1968, p. 43-51, (SChr 11). 416 SECRETARIADO NACIONAL DE LITURGIA, Antologia Litúrgica. Textos litúrgicos, patrísticos e canónicos do primeiro milênio, 2003, 4661 (p. 1126).
} 
- Anáfora de Nestório (séc. V): “/.../ pelo seu Sangue precioso nos resgatou e salvou, descendo aos Infernos e desfazendo as cadeias da morte que nos devorava"417.

- Cânon Romano: O Cânon Romano (ou Oração Eucarística I do atual Missal Romano) apresenta no "Unde et memores” (após o Relato da Instituição), uma discreta menção da descida de Cristo aos infernos, que praticamente desaparece nas traduções em português ${ }^{418}$. Em uma tentativa de tradução literal: "Por esta razão, Senhor, nós teus servos, e também teu povo santo, lembrando-nos da Santa Paixão do mesmo Cristo, teu Filho e Senhor nosso, assim como de sua ressurreição dos infernos, e de sua gloriosa ascensão aos céus" ${ }^{\text {«19. }}$.

\section{- Anáfora da liturgia mozarábica (pós-Santo):}

Verdadeiramente santo e verdadeiramente Filho de Deus é o Cristo que saiu do patíbulo da cruz afim de que, na sua morte, a morte perdesse todas as suas forças. Desceu aos infernos para retirar vitorioso o homem caído pela antiga culpa e feito escravo no reino do pecado, e para romper com mão poderosa as trancas das portas e abri-las para aqueles que o seguem á glória da Ressurreição ${ }^{420}$.

- Anáfora IV do atual Missal Romano: Inspirada na Anáfora de São Basílio, a oração Eucarística IV, do atual Rito Romano, traz também uma menção da descida de Cristo aos infernos: "Celebrando agora, ó Pai, a memória da nossa redenção, anunciamos a morte de Cristo e sua descida entre os mortos, proclamamos a sua ressurreição e ascensão à vossa direita".

Por motivos óbvios é na liturgia da Semana Santa que encontramos os maiores testemunhos litúrgicos referentes ao nosso tema, particularmente na liturgia oriental. No rito bizantino, a descida de Cristo aos infernos é o tema da

\footnotetext{
${ }^{417}$ Ibid. 4628 (p. 1112).

${ }^{418}$ Conferir a tradução brasileira: "Celebrando, pois, a memória da paixão do vosso Filho, da sua ressurreição dentre os mortos e gloriosa ascensão aos céus"; e a portuguesa: "Celebrando, agora, Senhor, o memorial da bem-aventurada paixão de Jesus Cristo, vosso Filho, nosso Senhor, da sua ressurreição de entre os mortos e da sua gloriosa ascensão aos céus". O mesmo se dá na tradução inglesa : "Father, we celebrate the memory of Christ, your Son. We, your people and your ministers, recall his passion, his resurrection from the dead, and his ascension into glory". A tradução francesa conserva melhor a referência: "C'est pourquoi nous aussi, tes serviteurs, et ton peuple saint avec nous, faisant mémoire de la passion bienheureuse de ton Fils, Jésus Christ, notre Seigneur, de sa résurrection du séjour des morts et de sa glorieuse ascension dans le ciel ».

419 Texto latino: "Unde et memores, Domine, nos servi tui, sed et plebs tua sancta, eiusdem Christi, Filii tui, Domini nostri, tam beata passionis, necnon et ab inferis resurrectionis, sed et in caelos gloriosa ascensionis".

${ }^{420}$ Citado conforme CHIALÀ, S.; Discese agli inferi, p. 24.
} 
noite da Sexta-feira Santa, sendo o principal enfoque da vitória do Senhor sobre os poderes infernais. Nos Encômios do Sábado Santo encontramos numerosas menções da descida de Cristo aos infernos: "Como suportará o inferno a tua vinda? Não ficará antes despedaçado, cego, ofuscado pelo fulgor resplandecente de tua luz? /.../ Agora, o corpo de Deus está oculto sob a terra, como uma lâmpada de luz debaixo do alqueire e expulsa as trevas infernais. /.../ Quando o inferno voraz engoliu a pedra da vida, ele vomitou os mortos que desde sempre devorara. /.../ Mesmo quando eras colocado no túmulo, no momento em que ias aos infernos, ó Cristo, abrias os túmulos dos mortos e despojavas o inferno". ( $1^{\mathrm{a}}$ estância). Também nos Tropários do mesmo dia: "Profetizando a tua divina humilhação sobre a Cruz, Habacuque clamava fora de si, dizendo: 'Tu desfizeste o poder dos fortes, ó bondoso, visitando os habitantes do Inferno, ó Onipotente!' /.../ O Inferno, vindo ao teu encontro, ó Verbo ficou cheio de amargura à vista de um mortal divinizado, coberto do chagas e Todo-Poderoso e perante o horror deste espetáculo, achou-se perdido" (4a . Ode, Hirmos e Tropário).

Na liturgia ocidental, além das Anáfora mozarábica e da atual Anáfora IV do Missal Romano, acima citadas, encontramos apenas oração das Laudes do Sábado Santo: "Pai cheio de bondade, vosso Filho unigênito desceu à mansão dos mortos e dela surgiu vitorioso..." ${ }^{421}$, bem como a famosa "antiga Homilia no grande Sábado Santo", no Ofício das Leituras do mesmo dia ${ }^{422}$.

\footnotetext{
${ }^{421}$ LITURGIA DAS HORAS II, p. 446.

${ }^{422}$ Ibid. Encontramos ainda menção do tema no refrão do canto processional de São Venâncio Fortunato (607), bispo de Poitiers: Salve, festa dies, toto venerabilis aevo. Qua Deus infernum vicit et astra tenet.
} 


\section{CAPÍTULO III - Os desdobramentos da descida de Cristo a morada dos mortos nos períodos medieval e moderno}

No que se refere à reflexão sobre a descida de Cristo a morada dos mortos, o período medieval tem como ponto alto o pensamento de Santo Tomás de Aquino $(\dagger$ 1274). Suas afirmações marcaram de tal forma a teologia católica que se tornaram, por assim dizer, a posição clássica da Igreja acerca do tema, sendo retomadas pelo Catecismo do Concílio de Trento.

O período moderno, por sua vez, foi marcado pelas controvérsias com os reformadores. Destes, Calvino foi quem apresentou o pensamento mais profundo acerca de nosso tema (pensamento que não deixou de ter influência, inclusive sobre pensadores católicos posteriores). No lado católico encontramos, nesse período, São Roberto Belarmino, cuja obra apresenta expressa intenção apologética.

\section{1 - A teologia medieval: Santo Tomás de Aquino.}

Na idade Média o tema da descida de Cristo a morada dos mortos já aparecera no o Sínodo de Sens (a.1140), que, opondo-se aos erros de Pedro Abelardo, condenou a afirmação "que a alma de Cristo não desceu aos infernos por si mesma, mas só por potência" ${ }^{423}$. Ainda, dez anos antes do nascimento de Santo Tomás, no tempo do Papa Inocêncio III, a Constituição De fide catholica do Concílio Lateranense IV (a. 1215), opondo-se ao dualismo dos cátaros, que atribuíam o mundo material às forças do mal, após professar a fé no Deus criador de todas as coisas, visíveis e invisíveis, e afirmar a realidade da encarnação, pela qual "o Filho de Deus encarnado, Jesus Cristo /.../ tornou-se verdadeiro homem, composto de alma racional e corpo humano, uma só pessoa em duas naturezas" afirmou que o mesmo Jesus Cristo "depois de ter sofrido na cruz e de ser morto pela salvação do gênero humano, desceu aos infernos, ressuscitou dos mortos e

${ }^{423}$ DHü 738. 
subiu ao céu; mas desceu em alma e ressuscitou em carne, subiu igualmente com uma e outra" 424 .

Devedor da cultua de sua época, como Dante Alighieri ${ }^{425}$, Santo Tomás de Aquino também imaginava os infernos situados debaixo da terra e composto de partes distintas. A descida de Cristo a morada dos mortos era, pois, entendida de modo local ${ }^{426}$.

O tema é tratado pelo Doctor Angelicus em três de suas obras, das quais, a mais conhecida é, sem dúvida, a Suma Teológica. Nela, ao tratar do Mistério da Encarnação do Filho de Deus, de sua vida, morte e ressurreição, Santo Tomás dedica a questão 52 ao nosso tema, abordando, em oito artigos, a razão, o lugar, a modalidade, a duração e os efeitos da descida de Cristo à morada dos mortos.

$\mathrm{O}$ artigo primeiro trata da razão da descida de Cristo à morada dos mortos. Santo Tomás utiliza o argumento da conveniência, afirmando que esta era oportuna em razão da salvação do pecado, para derrotar definitivamente o demônio e para manifestar sua glória:

\footnotetext{
${ }^{424}$ CONCILIORUM OECUMENICORUM DECRETA, 230. Il concilio iniziò il 1 novembre 1215 e durò appena tre settimane, con tre sedute plenarie in tutto. /.../ Sui modo in cui si giunse ai decreti non sapiamo praticamente nulla. Tenuto conto del poco tempo a disposizione e della quantità di decreti emanati si deve ritenere che la maggior parte di essi fosse stata preparata in antecipo e che al concilio le varie consultazioni li abbiano modificati solo molto marginalmente. (SCHATZ, K.; Storia dei Concili. La Chiesa nei suoi punti focali, 1999, p. 104).

${ }^{425}$ Cf. no Figura 5 p. 289, o esquema do Inferno segundo a Divina Comédia (http://projetodante.blogspot.com/2010/09/o-inferno-de-dante.html.

${ }^{426}$ Santo Tomás estava, todavia, consciente da objeção de que a alma de Cristo, "por ser incorpórea, parece que não pode se mover localmente" (Sum. Teol. III, q.52,a.1, 3, p. 736) ${ }^{1}$, à qual responde dizendo que "a alma de Cristo não desceu aos infernos pelo mesmo gênero de movimento com que os corpos se movem, mas pelo gênero de movimento com que os anjos se movem" (Sum. Teol. III, q.52,a.1, ad 3, p. 737) ${ }^{1}$. A relação entre o movimento da alma de Cristo e o movimento angélico já havia sido afirmada na primeira parte da Suma, quando concluiu que os anjos deveriam ser capazes de mover-se localmente, pois "pela mesma razão pode mover-se o anjo bem-aventurado e a alma bem-aventurada. Ora, é necessário admitir-se que esta se move localmente, pois é artigo de fé que a alma de Cristo desceu aos infernos. Logo, o anjo beato se move localmente" (Sum. Teol. II, q.53, a.1) ${ }^{2}$. Segundo ele, a ocupação de um lugar por um anjo deve ser entendida não como uma presença por quantidade dimensionada (como os corpos), mas por uma "quantidade de virtual" (de atuação), "assim semelhantemente diz-se que o anjo está num lugar corpóreo, não como contido, de certo modo" (Sum. Teol. II, q.52, a.1, sol.) 2 . "Não estando o anjo em um lugar senão pelo contacto da sua virtude como já se disse, o movimento local do anjo não será, por força, senão os seus diversos contactos com os diversos lugares sucessiva e não simultâneamente, porque o anjo não pode estar simultâneamente em varios lugares, como antes se disse" (Sum. Teol. II, q.53, a.1, sol.) ${ }^{2}$. Assim também deve ser entendida a "descida de Cristo aos infernos".
} 
Foi conveniente que Cristo tenha descido aos infernos. Primeiro, porque ele viera assumir nossa pena para dela nos livrar, como de até lá descer. Por isso, diz o livro de Oséias: 'Morte eu serei tua morte! Inferno, eu serei tua mordida'. Segundo, porque era conveniente que, tendo sido vencido que mantinha nos infernos. É o que diz o livro de Zacarias: 'Quanto a ti, por causa da aliança firmada contigo no sangue, libertarei os teus cativos da cisternasem água'. E a Carta aos Colossences diz: 'Despojou os principados e as potestades e os expôs publicamente'. Terceiro, para que, ao viver e ao morrer, também o mostrasse nos infernos, ao visitá-los e iluminá-los. Por isso, diz o Salmo 23: 'Príncipes, levantai vossas portas', que a Glosa interpreta: 'Ou seja, príncipes dos infernos, retirai vosso poder com que detínheis até agora os homens', e assim, conforme diz a Carta aos Filipenses: 'Ao nome de Jesus todo joelho se dobre', não apenas nos céus', mas também 'nos infernos' ${ }^{427}$.

$\mathrm{O}$ artigo segundo se refere ao lugar, nele $\mathrm{S}$. Tomás explica que, "por sua essência /.../ a alma de Cristo desceu somente ao local dos infernos onde os justos estavam detidos, afim de visitar também in loco, segundo a sua alma, aqueles que ele, segundo a divindade, visitava pela graça interior" ${ }^{\text {"28 }}$. Nas demais partes do inferno, Cristo esteve apenas pelo efeito dessa descida (ao lugar dos justos). Assim, no "inferno dos condenados, ele realizou o efeito de censurar a incredulidade e malícia deles", aos "que estavam detidos no purgatório, porém, deu esperança de conseguirem a glória" ${ }^{429}$.

O artigo terceiro é dedicado ao modo pelo qual Cristo esteve no inferno. Fundamentando-se na união hipostática, Santo Tomás intentou demonstrar, através de uma complexa especulação teológica, que Cristo esteve inteiro nos infernos:

na morte de Cristo, embora a alma estivesse separada do corpo, nenhum dos dois esteve separado da pessoa do filho de Deus, como foi dito acima. Logo, nos três dias da morte de Cristo temos de afirmar que Cristo, todo ele, esteve no sepulcro, pois toda a pessoa ali esteve pelo corpo a ela unido. De modo semelhante, esteve inteiro nos infernos, pois toda a pessoa de Cristo ali esteve em razão da alma a ela unida. Cristo inteiro, por conseguinte, estava em qualquer lugar em razão da natureza divina ${ }^{430}$.

\footnotetext{
${ }^{427}$ Sum. Teol. III, 52,1, p. $736-7 .^{1}$

${ }^{428}$ Sum. Teol. III, 52,2, p. 739. ${ }^{1}$

${ }^{429}$ Id.

${ }^{430}$ Sum. Teol. III, 52,3, p. $741^{1}$
} 
O artigo terceiro é dedicado ao tempo no qual Cristo esteve no inferno.

Assim como Cristo, afim de assumir em si as nossas penas, quis que seu corpo fosse posto num sepulcro, também quis que sua alma descesse aos infernos. O corpo dele, porém, ficou no sepulcro um dia inteiro e duas noites, para comprovar a realidade de sua morte. Por isso acreditamos que sua alma permaneceu também nos infernos durante esse mesmo tempo, para que, simultaneamente, saísse a alma dos infernos e o corpo, do sepulcro ${ }^{431}$

Desse inferno, porém, transfigurado pela presença de Jesus, podia-se já dizer ser o Paraíso, pelo que foi cumprida a promessa feita ao bom ladrão (Lc 23,43): "Por isso, o ladrão desceu com Cristo até o local dos infernos a fim de ficar com ele, uma vez que lhe fora dito: 'Hoje, estarás comigo no paraíso', pois lá gozava da divindade de Cristo, como os demais santos" ${ }^{432}$.

Nos quatro últimos artigos da questão $52^{1}$, Santo Tomás aborda os efeitos salvíficos da descida de Cristo à morada dos mortos, afirmando a libertação das almas dos santos patriarcas (art. 5) (333 $^{4}$ das almas do purgatório "que já estavam suficientemente purificadas, ou também aos que, ainda em vida mereceram, pela fé, amor e devoção à em relação à morte de Cristo, ser libertados da pena temporal do purgatório, quando Cristo lá desceu” ( art. 8, ad 1). Rejeitando qualquer teoria apocatasta, Santo Tomás afirma, porém, que a descida de Cristo a morada dos mortos não libertou nenhum dos condenados (art. 6), nem as almas das crianças que morreram com o pecado original (art. 7).

Também na Exposição In Symbolum Apostolorum ${ }^{434}$ Santo Tomás trata de nosso tema. A obra reúne as pregações por ele feitas aos fiéis de Nápoles, na Quaresma de 1273, explicando o Símbolo Apostólico. A perspectiva apresentada difere sensivelmente da Suma, por sua abordagem mais soteriológica e, em razão do público, pelo enfoque parenético.

\footnotetext{
${ }^{431}$ Sum. Teol. III, 52,4, p. 743. ${ }^{1}$

${ }^{432}$ Sum. Teol. III, 52,4, ad 3, p. 743. ${ }^{1}$

${ }^{433}$ Estes, segundo Santo Tomás, "enquanto viviam, tinham sido libertados, pela fé em Cristo, de todo pecado tanto original como atual, bem como da dívida da pena dos atuais pecados: não todavia, da dívida do pecado original, pela qual ficavam excluídos da glória, uma vez que não estava ainda pago o preço da redenção humana" (art. 5, ad 2).

434 TOMAS DE AQUINO, O Credo. Petrópolis: 2006.
} 
Após breve introdução de caráter cristológico ${ }^{435}$ Santo Tomás apresenta quatro razões para a descida de Cristo à morada dos mortos.

\section{A primeira razão foi para}

que pudesse sofrer todo o castigo do pecado, e assim a culpa fosse completamente expiada. $\mathrm{O}$ castigo do pecado do homem não consistia somente na morte do corpo, mas também num sofrimento para a alma. Visto que esta havia pecado, cabia-lhe ser punida pela privação da visão de Deus. Não se tinha ainda oferecido uma satisfação por essa pena ${ }^{436}$.

Por isso Cristo, a fim de suportar totalmente, e de modo perfeito a pena devida aos pecadores, quis, não apenas morrer, mas também descer com sua alma aos infernos ${ }^{437}$.

A segunda razão foi "para socorrer perfeitamente todos os seus amigos" que lá jaziam, a saber, os justos da antiga Aliança. "Uma vez que Cristo havia visitado seus amigos no mundo, e os socorrera com sua própria norte, quis, também, visitar os amigos que estavam nos infernos, socorrendo-os, descendo até eles" $" 438$.

A terceira razão foi para "triunfar perfeitamente sobre o diabo". Cristo já havia vencido o demônio por sua morte na cruz, mas quis derrotá-lo definitivamente e de modo perfeito, acorrentando-o em sua casa, que é o inferno, e tomar sua presa $\_$os fiéis, que ele mantinha cativos. "Como Cristo recebera a posse do céu e da terra, quis também ter a posse dos infernos" $(F 12,10)^{439}$.

A quarta e última razão "foi libertar os santos que estavam nos infernos. Assim, como Cristo quis submeter-se à morte para libertar os vivos, quis, também,

${ }^{435}$ Conforme foi dito, a norte de Cristo consistiu na separação entre sua alma e seu corpo, como acontece na norte de qualquer homem. A Divindade, porém, estava tão indissoluvelmente unida ao homem Jesus, que, por mais que sua alma e seu corpo se separassem entre si, continuou ligada ao seu corpo e à sua alma, de forma perfeitíssima. Eis por que o Filho de Deus tanto permaneceu com o corpo no sepulcro, como desceu com a alma aos infernos (à mansão dos mortos). Idem, p.59

${ }^{436}$ Id., p. 60

437 Tal afirmação não é idêntica à que encontramos na Summa, nem, como veremos, no Comentário às Sentenças de Pedro Lombardo, onde se diz expressamente que "Christo fuit competens in infernum descendere, secundum quod infernus importat locum, non autem secundum quod importat poenam" (Super III Sent., d. 22, q.2,a.1,sol.1). A idéia seria, mais tarde desenvolvida pelo teólogo suíço Hans Urs von Balthasar (como teremos ocasião de apresentar).

${ }^{438}$ TOMAS DE AQUINO, op. cit. p. 60

${ }^{439}$ Id., p. 61. 
descer os infernos, para libertar os que lá se achavam" ${ }^{440}$. Negando a tese da salvação apocatasta, Santo Tomás afirma que "embora Cristo tivesse destruído totalmente a morte, não destruiu totalmente o inferno, mas como que lhe deu uma mordida?, visto que não libertou a todos que lá estavam. Libertou, unicamente, os que lá estavam sem pecado mortal". Pelo que "deixou, pois, no inferno, os que ali estavam com pecado mortal, e as crianças que não haviam sido circuncidadas"441.

A essa explicação de caráter teológico, Santo Tomás acrescenta uma meditação de cunho parenético, com quatro conclusões. A primeira delas é a firme esperança em Deus, que todos devem ter:

Por mais afligido que o homem esteja, deve esperar ajuda de Deus, e confiar nele. Não há nada mais grave do que estar no inferno. Ora, se Cristo libertou os que lá estavam, todo homem que verdadeiramente for amigo de Deus deve ter total confiança de que Ele o livrará de qualquer angustia ${ }^{442}$

A segunda é que a do temor de Deus e afastamento da presunção, que deriva da consciência da eternidade das penas infernais:

Embora Cristo tenha padecido pelos pecadores, e descido aos infernos, não libertou a todos, porém tão-somente os que se achavam sem pecado mortal, conforme dito. Os que tinham morrido em pecado mortal, deixou-os no inferno. Portanto, ninguém, que morra em pecado mortal, espere ser perdoado. Ficarão ali durante o tempo em que os Santos Patriarcas ficarem no paraíso, isto é, para sempre $^{443}$

A terceira é o conselho da vigilância e da meditação frequente sobre as penas infernais: "aquele que, em vida, desce com o pensamento ao inferno, com certa frequencia, não irá parar lá tão facilmente depois da morte, uma vez que esse pensamento o afasta do pecado ${ }^{444 \text {, }}$.

A quarta, por fim, é a caridade para com as almas do purgatório, a exemplo de Cristo, que "desceu até lá para libertar aqueles a quem amava. Ora, nós também devemos descer até lá para ajudar aqueles a quem amamos. Os que estão no purgatório não podem se ajudar a si mesmos ${ }^{445}$ ".

$$
\begin{aligned}
& { }^{440} \text { Id. } \\
& { }^{441} \text { Id., p. } 61-62 \\
& { }^{442} \text { Id. } \\
& { }^{443} \text { Id., p. } 63 \\
& { }^{444} \text { Id. } \\
& { }^{445} \text { Id., p. } 64
\end{aligned}
$$


A descida de Cristo aos infernos aparece, por fim, numa obra menos conhecida do Aquinate, o Comentário às Sentenças de Pedro Lombardo ${ }^{446}$, onde o tema é tratado junto à questão da relação existente entre a divindade e a humanidade de Cristo após sua morte. Apresentando as razões pelas quais a Divindade deveria manteve-se unida à carne de Cristo (e à sua alma), mesmo enquanto ele estava morto ${ }^{447}$. Santo Tomás afirma (na terceira razão) que o mistério da encarnação deveria, em razão de sua própria finalidade, permanecer eficaz também após a morte de Cristo ${ }^{448}$, o que só poderia acontecer em razão da presença da Pessoa divina, que sustentava os atos realizados por Jesus após sua morte. Esses atos post-mortem foram realizados em sua descida aos infernos. A essa descida ele dedica dois artigos: "De descensu Christi ad inferos" e "De effectu quem ibi fecit".

Para Santo Tomás, a descida de Cristo à morada dos mortos é consequência do mistério da encarnação, visto que nela Cristo assumiu, para nos redimir, as condições concretas da existência humana, entre as quais estava, antes de sua Paixão, o inferno ${ }^{449}$. Cristo, porém, não sofreu as penas dos condenados, nem mesmo a "tenebrarum experientiam" que experimentavam os santos patriarcas, descendo ao inferno apenas enquanto lugar ${ }^{450}$.

\footnotetext{
${ }^{446}$ O texto latino de Scriptum super Libros Sententiarum pode ser achado no Archivio della Latinità Italiana del Medioevo da Unione Accademica Nazionale (Itália) http://www.uan.it/alim/letteratura.nsf/\%28cercaVolumi\%29/BE284BD30AFD990CC12571BE003 48172?OpenDocument

447 "Corpus Christi in morte non fuit separatum Deitate" (Super III Sent., d.21, q.1, a.1, sol.1, in http://www.uan.it/alim/letteratura.nsf/\%28cercaVolumi\%29/BE284BD30AFD990CC12571BE003 48172?OpenDocument

${ }^{448}$ Tertio ex fine assumptionis: quia ea quae post mortem ipsius circa ipsum acta sunt, salutaria nobis non fuissent, nisi Deitas adiuncta esset. (Ibid.).

449 /.../erat omnibus hominibus commune ante passionem Christi quod pro debito originalis peccati ad infernum descendebant. (Super III Sent., d.22, q.2, a. 1, q.3, sol. 1, Ibid.)

${ }^{450}$ Christo fuit competens in infernum descendere, secundum quod infernus importat locum, non autem secundum quod importat poenam. (Ibid.)
} 
Ao admitir, a opinião corrente de diversos infernos ${ }^{451}$ (ou um inferno composto e diversas partes), Santo Tomás afirmava que Cristo desceu apenas ao inferno superior, onde estavam os santos patriarcas ("infernus sanctorum patrum”), não ao purgatório ("purgatorium”) ou ao limbo das crianças ("limbus puerorum") ou, menos ainda, ao inferno dos condenados ("infernus damnatorum").

Quanto a eficácia da descida de Cristo aos infernos, afirmava que nela Cristo iluminou os santos patriarcas ${ }^{452}$, libertando-os ${ }^{453}$. Mas não libertou os que estavam no inferno dos condenados ${ }^{454}$, ou as crianças do limbo ${ }^{455}$; quanto aos que estavam no purgatório, também não foram libertados ${ }^{456}$, a não ser aqueles que em sua vida o mereceram ${ }^{457}$.

\footnotetext{
$451 / . . . /$ quadruplex est infernus. Unus est infernus damnatorum, in quo sunt tenebrae et quantum ad carentiam divinae visionis, et quantum ad carentiam gratiae, et est ibi poena sensibilis; et hic infernus est locus damnatorum. Alius est infernus supra istum, in quo sunt tenebrae et propter carentiam divinae visionis, et propter carentiam gratiae, sed non est ibi poena sensibilis; et dicitur limbus puerorum. Alius supra hunc est, in quo sunt tenebrae quantum ad carentiam divinae visionis, sed non quantum ad carentiam gratiae, sed est ibi poena sensus; et dicitur purgatorium. Alius magis supra est, in quo est tenebra quantum ad carentiam divinae visionis, sed non quantum ad carentiam gratiae, neque est ibi poena sensibilis; et hic est infernus sanctorum patrum; et in hunc tantum Christus descendit quantum ad locum, sed non quantum ad tenebrarum experientiam (Super III Sent., d.22, q.2, a. 1, q.3, sol.2, Ibid.).

452 /.../ex quo Christus a patribus qui erant in limbo, omnes tenebras interiores expulerat per demonstrationem suae Deitatis, congruum etiam fuit per praesentiam suae humanitatis quantum ad animam etiam tenebras exteriores ab eis excludere, locum illuminando. (Super III Sent., d.22, q.2, a. $1, \mathrm{q} .4$, sol.1, Ibid.).

453 /.../ quod eduxit eos de tenebris dum eos illuminavit: et educens eos de loco illo dicitur de tenebris eduxisse, quas locus ille de sui natura prius habuerat. (Ibid.).

$454 / . . . /$ illi autem qui sunt damnati in inferno, sunt obstinati in malitia, sicut daemones; et ideo de poena illi liberari non potuerunt: et hoc non fuit ex insufficientia liberantis, sed ex indispositione ipsorum. (Super III Sent., d.22, q.2, a. 1, q.4, sol.2, Ibid.).

455 /.../ quod redemptio Christi non habuit locum nisi in illis qui fuerunt membra Christi: unde cum pueri qui erant in limbo, nunquam fuerint membra Christi neque per propriam fidem, neque per fidei sacramentum (quod nunc est baptismus, tunc autem erat circumcisio, vel sacrificium), constat quod ipsi liberati non fuerunt. (Super III Sent., d.22, q.2, a. 1, q.4, sol.3, Ibid.).

$456 / . . . /$ quod quamvis hoc non inveniatur determinatum a sanctis, potest tamen dici, quod illi qui erant in purgatorio, non fuerunt liberati: quia cum poena purgatorii debeatur peccato actuali; oportet quod expietur per proprium actum, vel passionem illius qui peccavit, vel alterius specialis personae agentis pro ipso. In purgatorio autem non potest culpa expiari per aliquem actum meritorium, quia non sunt in statu merendi: unde oportet quod expietur eorum culpa per poenam, quam ipsi sustineant, nisi per suffragia eorum qui sunt in statu merendi, liberentur. (Super III Sent., d.22, q.2, a. 1, q.4, sol.4, Ibid.).

${ }^{457}$ Nisi dicatur, quod in vita sua hoc meruerunt ut per passionem Christi liberarentur. (Ibid.).
} 
Ainda no período medieval, encontramos breve menção ao nosso tema na Carta Cum dudum (agosto de 1341), do Papa Bento XII, o qual, condenando proposições teológicas atribuídas aos armênios, tratou do tema do Descensus junto a questões relacionadas ao pecado original e ao batismo:

Cristo se encarnou e padeceu pela salvação dos homens, porque pela sua paixão, os filhos de Adão que viveram antes da dita paixão foram libertos do inferno, no que, porém, se encontravam não por causa de um pecado original que estivesse neles, mas por causa da gravidade do pecado pessoal dos primeiros progenitores. Crêem que Cristo se encarnou e padeceu pela salvação das crianças que nasceram depois de sua paixão, porque por meio de sua paixão destruiu totalmente o inferno ${ }^{458}$.

Dez anos depois, Clemente VI, na Carta Super quibusdam a Mekhitar, Katholikós dos armênios, interrogava se os armênios acreditavam que "Cristo não destruiu, quando desceu aos infernos, o inferno inferior" ${ }^{\prime 45}$.

\subsection{A teologia moderna: João Calvino}

As Institutio Religionis Christianae 460 do reformador Calvino († 1564) apresentam uma notável reflexão sobre o tema que nos propomos. Encontramos-la na parte dedicada ao Símbolo, Livro II, capítulo 16: "Como Cristo cumpriu as funções de Redentor para que nos adquirisse a salvação, onde se trata de sua Morte e Ressurreição, bem como de sua Ascensão ao céu”. No capítulo, a descida de Cristo às regiões infernais é tratado nos nn. 8 a 12.

Calvino começa afirmando a importância do tema em razão de seu conteúdo soteriológico: "não convém omitir sua descida aos infernos, que não é

\footnotetext{
${ }^{458}$ DHü 1011

$459 / . . . /$ non destruxit descendendo ad ínferos inferiorem infernum. (DHü 1077).

${ }^{460}$ No presente trabalho seguimos, de um modo geral a tradução de Waldyr Carvalho Luz "As Institutas ou Tratado da Religião cristã. Edição clássica" (http://www.scribd.com/doc/6915088/Joao-Calvino-Institutas-2-traducao-do-latim 07/01/2011 17:26), cotejado, quando necessário, com o texto original: Ioannis Calvino Institutio Christianae Religionis, cum brevi annotatione atque locupletissimis ad editionem amestelodamensem accuratissime exscribi curavit A. Tholuck. Berolini apud Gustavum Eichler, 1834, Londres, Pairs e Genebra.
} 
de pequena importância para efeito da redenção. /.../ ele contém mistério excelente e longe de desprezar-se de matéria da máxima relevância"461.

Calvino, a seguir, opõe-se a duas interpretações do referido artigo do Símbolo: a primeira, de tipo reducionista, que identifica a descida aos infernos com a sepultura de Jesus: "Há também, por outro lado, os que afirmam que aqui não se diz algo novo, mas apenas se repete, em outras palavras, o que fora antes dito acerca do sepultamento, uma vez que nas Escrituras amiúde se emprega o termo Inferno em lugar de sepultura" ${ }^{462}$. Declara o reformador que a afirmação do Símbolo "desceu às regiões infernais", não pode ser tomada como explicação de "foi sepultado", nem se pode supor que "nesta síntese, na qual resumidamente, quanto se pode fazer no menor número de palavras, se compendiam os principais artigos da fé, pudesse insinuar-se uma repetição tão supérflua"463.

A segunda interpretação a qual se opõe Calvino, de tipo mais "mitológico", é a da descida Cristo aos infernos para libertar as almas dos justos ali aprisionados:

Outros o interpretam diferentemente, dizendo que Cristo desceu às almas dos Patriarcas que haviam morrido sob a lei, para que lhes levasse a proclamação da redenção consumada, e as livrasse do cárcere onde se mantinham encerradas. /.../ Não sei como haja acontecido que a posteridade imaginasse existir um lugar subterrâneo a que deram o nome de limbo. Mas, a despeito de esta fábula contar com grandes autores, e é hoje também seriamente defendida por muitos como sendo a verdade, entretanto não passa de fábula. Ora, a idéia de encerrar as almas dos mortos em um cárcere é pueril. Que necessidade, pois, houve de a alma de Cristo descer ali para que ele as libertasse? ${ }^{464}$

Calvino conhece a relação do texto de 1 Pd 3,19 com o tema, sendo que, dele extrai seu significado essencial: a universalidade da salvação obtida pela morte de Cristo, que se estende até as almas dos que morreram antes de sua manifestação:

${ }^{461}$ Ibid, art. 8, p. 265

${ }^{462}$ Art. 9, p. 266.

${ }^{463}$ Ibid.

${ }^{464}$ Ibid. art. 10, pp. 266-267. Quod Christus descenderit ad animas Patrum, qui sub Legem mortui erant, ut nuntium peractae redemptionis perferret, ac erueret eas ex carcere, ubi inclusae tenebantur. /.../ nescio qui factum sit, ut posteritas locum putaret esse subterraneum, cui afinxit nomem Limbi. Sed haec fabula tametsi magnos auctores habet, et hodie quoque a multis serio pro valitate defenditur, nihil tamen fabula quam est. Nam concludere in carcere mortuorum animas puerile est: Christi autem animam illuc descendere, ut eas manumitteret, quid opus fuit?. (Institutio pp. 333-334) 
Ora, até mesmo o contexto nos conduz a isto: que os fiéis que morreram antes desse tempo foram co-participantes conosco da mesma graça, pois que Pedro daí amplia o poder da morte de Cristo, que tenha ela penetrado até os mortos, enquanto as almas piedosas têm desfrutado da visão atual dessa visitação, que haviam ansiosamente esperado ${ }^{465}$.

Calvino entende e interpreta o artigo da descida de Cristo aos infernos como a afirmação de sua assunção da morte na totalidade de seu corpo e alma: "Nada aconteceria se Cristo tivesse experimentado apenas a morte corporal" "E, na verdade, a menos que também sua alma fosse participante do castigo, teria Cristo sido Redentor apenas dos corpos" ${ }^{\prime 67}$.

Tendo, pois, rejeitado a interpretação mitologizante tradicional, Calvino entende o termo "inferno" como expressão do abandono extremo de Deus sofrido por Jesus:

para que saibamos não só que o corpo de Cristo foi entregue por preço de redenção, mas houve também um preço maior e mais excelente, a saber, que ele sofreu na alma os terríveis tormentos de um homem condenado e perdido" 468 . "Nós, porém, estamos afirmando que ele suportou o peso da severidade divina, porquanto, ferido e afligido pela mão de Deus, experimentou todos os sinais de um Deus irado e punitivo. ${ }^{469}$

Como se já pode notar pelos textos apresentados, a compreensão de Calvino da descida de Cristo aos infernos é marcada pela perspectiva da Reforma, com soteriologia de acentuada ênfase, no caráter penal, e na teoria da satisfação:

Pouco antes referimos do Profeta que 'foi imposto sobre ele o castigo de nossa paz'; que 'ele foi ferido' pelo Pai 'por causa de nossas transgressões'; que 'foi esmagado por causa de nossas enfermidades' [Is 53.5], palavras com as quais significa ter-se submetido por fiador, avalista e até mesmo como culpado, em lugar dos transgressores, para que pagasse e saldasse todas as penas que deles se deveriam exigir, excetuado apenas isto: que 'não podia ser retido pelos tormentos da morte' [At 2.24]. Portanto, nada há de surpreendente dizer-se que ele desceu aos infernos, uma vez que tenha ele sofrido esta morte infligida aos pecadores por um Deus irado. ${ }^{470}$

${ }^{465}$ Ibid. p. 267

${ }^{466}$ Nihil actum erat, si corporea tantum morte defunctus fuisset Christus. (p. 334).

${ }^{467}$ Et sane nisi poenae fuisset particeps anima, corporibus tantum fuisset Redemptor. (p. 335).

$468 / . . . /$ ut sciamus non modo corpus Christi in pretium redemptionis fuisse traditum, sed alius maius et excellentius pretium fuisse, quod diros in anima cruciatus damnati ac perditi hominis pertulerit. (Ibid.).

469 Sed hoc nos dicimus, divinae severitatis gravitatem eum sustinuisse: quoniam manu Dei percussus et afflictus, omnia irati et punientis Dei signa expertus est. (p. 335).

${ }^{470}$ Ibid, pp. 267-268. 


\subsection{1. - São Roberto Belarmino.}

O cardeal jesuíta trata do tema em suas Disputationes de controversiis christianae fidei adversus hujus temporis hereticos ${ }^{471}$, atendo-se, como foi dito, ao pensamento de Santo Tomás, que já havia se tornado doutrina tradicional católica $^{472}$. Sua obra, porém, é de grande erudição, na qual o conhecimento exegético (com freqüentes as referências à Escritura em suas línguas originais) se une ao patrístico e teológico. No Livro IV De Christi Anima, após tratar das controvérsias a respeito da ciência da alma de Cristo (cap. 1), ele se ocupa das questões "se e como Cristo desceu aos infernos".

São Roberto apresenta como fundamentação bíblica, do artigo contido no Símbolo Apostólico, os textos tradicionais de At 2,31, e de Ef 4,9. Sabia que o artigo não estava presente nas profissões de fé mais antigas, como atestam os diversos comentários dos Padres (dos quais ele cita Irineu, Orígenes e Tertuliano e Agostinho), que em suas exposições sobre o Símbolo, não o mencionavam, passando direto do sepultamento à Ressurreição do Senhor ${ }^{473}$ (embora o façam Cirilo e João Crisóstomo). Afirma que a dificuldade já fora notada por Rufino de Aquiléia, que a resolveu entendendo estar a afirmação da descida aos infernos contida implicitamente na afirmação da sepultura ${ }^{474}$. Em favor dessa interpretação ele argumenta afirmando não ser possível que se oponham os Símbolo Niceno (que não contém o artigo) e o Símbolo (Pseudo) Atanasiano (que o contém). Citando Santo Anselmo, afirma que o artigo, mesmo não estando presente no Símbolo Niceno, recebe sumo consenso de todas as Igrejas orientais e ocidentais; ele mesmo cita as obras de hereges, Lutero e Calvino, que também o admitem (cap. 6).

\footnotetext{
${ }^{471}$ Roberti cardinalis BELLARMINI, Opera Omnia I, Disputationes de controversiis christianae fidei adversus hujus temporis hereticos, Josephum Giuliano Editorem, Neapoli, 1836.

${ }^{472}$ A dependência do pensamento de Santo Tomás é explícita; conferir, por ex. o cap. 16: Ad quae loca inferni descenderit B. Thomas 3. P. q.32 art.2 docet, Christum per realem presentiam solum descendisse ad lymbum Patrum: per effectum autem ad omnia loca inferni; nam damnatos incredulitatis arguit, eis vero qui purgabantur spem gloriae dedit.

473 /.../ explicant regulam Fidei ab apostolis traditam, et non meminerunt hujus particulae, sed a Sepultura transeunt ad Ressurrectionem. (p. 270).

$474 / . . . /$ tamen implicite contineri in articolo de sepultura, quia sicut corpus descendit ad locum corporum, ita anima ad locum animarum. (ibid.)
} 
No contexto de controvérsia, próprio da obra, São Roberto passa, então, a opõe-se aos ensinamentos de João Brenz, que identificava a descida de Cristo aos infernos a um aniquilamento (cap. 7) ${ }^{475}$.

A seguir, no capítulo 8, após apresentar um resumo do ensinamento de Calvino, refuta com diversos argumentos, a afirmação que Cristo teria padecido as penas dos condenados ao inferno ${ }^{476}$. As Escrituras atribuem nossa salvação à morte corporal de Jesus e desconhecem um sofrimento por Ele sofrido após a morte; as palavras de Cristo na cruz (evangelho de Lucas) não o mostram temendo pela própria salvação; a Igreja nunca celebrou um padecimento infernal de Jesus pela nossa salvação, logo, "ou a Igreja sempre foi ingratíssima, ou são fíç̧ões o que ensinou Calvino" 477 .

Refuta, a seguir, (cap. 9) os que identificam a descida de Cristo aos infernos com o seu sepultamento (Martin Bucer, Teodoro de Beza) ${ }^{478}$, aos quais responde afirmando a realidade dos infernos, "lugar subterrâneo distinto da sepultura" (tema depois desenvolvido no cap. 10), e que, assim como as almas dos que morreram antes de Cristo não foram ao céu, mas aos infernos subterrâneos (cap. 11), assim também a alma de Cristo, que desceu onde estavam as almas, desceu a esses infernos (tema retomado no cap. 12). Após analisar no cap. 13 o locus obscurissimus da 1Pd 3,18-19; 4,6 $6^{479}$, São Roberto apresenta no capítulo 14 abundante fundamentação patrística (cerca de vinte citações), para comprovar que o descensus difere do sepultamento.

Por fim, São Roberto se opõe novamente a Calvino, que interpretava metaforicamente sua descida aos infernos (identificando-a com seus efeitos

\footnotetext{
475 Prima sententia est, quod descendere ad ínferos sit penitus interire et extingue. Brentius in Catech. Anni 1551. dicit, descendere ad inferos, esse penitus interire. Et in Act. introducit Christum sic loquentem: Descendam in infernum, sentiam dolores inferni, et plane periisse videbor (Lib. IV 7, p. 270)

${ }^{476}$ Altera sententia est eiusdem Calvini lib. 2 Inst. Cap. 16... ubi docet, Christum dici descendisse ad inferos, quia passus est dolores animarum damnatorum (Lib. IV 8, p. 271).

${ }^{477}$ Ibid. p. 272.

${ }^{478}$ Sequitur tertia explicatio, explicatio, quae est Buceri... et Bezae qui docent, intelligi sepulchrum in Scripturis nomine inferni; proinde nihil esse aliud, Christum descendisse ad ínferos, quam sepultum esse (Lib. IV 9, p. 275-276).

${ }^{479}$ Ibid. p. 280. São Roberto se opõe as interpretações de Santo Agostinho (carta a Evódio, que já tivemos ocasião de analisar), de Teodoro de Beza (dependente de Agostinho) e de Calvino.
} 
salvíficos aos patriarcas no limbo) e a Guilherme Durand, que não sabia afirmar se essa descida era segundo a essência, ou se referia apenas a seus efeitos ${ }^{480}$.

\subsection{2 - O Catecismo Tridentino.}

Concluído o Concílio Tridentino (a. 1563), o Papa São Pio V mandou publicar o assim chamado Catecismo Romano, ou Tridentino ${ }^{481}$, o qual foi para o século XVI, uma referência para a formação do clero e para a formação da religiosidade católica no mundo ocidental, de acordo com a fé tridentina. Em sua $1^{\text {a }}$ parte, cap. 6, o Catecismo Tridentino tratou da descida de Cristo aos infernos. No n. 91 se apresenta o tema: "este artigo nos propõe para crer que, tendo Cristo morrido, sua alma desceu aos infernos, e ali permaneceu, enquanto seu corpo esteve no sepulcro", insistindo em afirmar que "ainda que a alma tenha se separado do corpo, nunca a divindade se separou nem da alma, nem do corpo" de Cristo.

No art. 92 o Catecismo interpreta realisticamente a afirmação, dizendo ser ímpia e ignorante a posição que identifica o Descensus com o sepultamento do Senhor, justificando essa afirmação no art. seguinte: "Porque tendo nos ensinado o artigo anterior que Cristo Senhor foi sepultado, não haveria causa alguma para que os santos Apóstolos, ao ensinar a fé, repetissem uma mesma coisa de um modo distinto e mais obscuro".

O artigo 94 distingue os vários significados da palavra "infernos": o inferno dos condenados, o purgatório e "a terceira classe de inferno, aquele no qual eram recebidas as almas dos santos antes da vinda de Cristo", às quais Cristo libertou quando desceu aos infernos.

Ainda que a alma de Cristo tenha descido aos infernos "não só por sua virtude, mas também com sua presença real” (art. 95), em "nada diminuiu seu

480 Calvinus sententiam suam vult esse certissima: Durandus vero dicit, non esse pertinaciter asserendum, Christi animam non descendisse secundum essentiam ad infernum, immo forte descendisse, sed id non constare, cum tamen constet, eum descendisse secundum effectum. (ibd. p. 284).

${ }^{481}$ CATECHISMVS, Ex Decreto Concilii Tridentini, ad Parochos Pii Quinti Pont. Max. Iussu editusad, editionem Romae A. D. MDLXVI publici iuris factam accuratissime expressus 
poder supremo, nem o esplendor de sua santidade contraiu a menor mancha /.../ desceu não para padecer, mas para livrar aqueles santos e homens justos da miserável moléstia daquele cárcere” (art. 96). "Cristo desceu aos infernos para que, tomando aos demônios seus despojos e libertando aqueles santos Pais e demais justos do cárcere, os levasse consigo ao céu" (art. 97). O Descensus revela, pois, que "pelo benefício da Paixão, conseguiram a salvação eterna não somente os justos que nasceram depois da vinda do Senhor, mas também todos os que o antecederam, desde Adão, e a quantos houverem até o final do mundo" (art. 97).

\section{3 - A descida de Cristo aos infernos: Período contemporâneo.}

Na teologia contemporânea, o tema da descida de Cristo foi retomado com maior vigor, ultrapassando-se os limites nos quais havia, de certo modo, se encapsulado com a teologia tomista. Se a "teologia romana" continuasse a manter as posições anteriores (como demonstram o Catecismo da Igreja Católica e os pronunciamentos do Papa João Paulo II), diversos teólogos tratariam o tema com enfoques diferentes, quer retomando intuições da teologia patrística, quer tomando posições originais (algumas nem sempre ortodoxas). Entre eles se destaca o teólogo suíço Hans Urs von Balthasar. Para organizar a apresentação, após a exposição da teologia oficial, dividiremos os autores por grupos linguísticos.

\subsection{O magistério de João Paulo II}

O Papa João Paulo II tratou do tema da descida de Cristo aos infernos, na Audiência geral de 11 de janeiro de 1989, em uma catequese sobre o Símbolo Apostólico. Após citar as passagens bíblicas tradicionalmente associadas ao Descensus, e dizer que, no presente caso, "inferno" não se refere ao "estado de danação, mas a morada dos mortos" o Papa interpreta a expressão: “desceu aos infernos" como indicadora da realidade da morte real de Jesus e de sua salvação, que alcançou as gerações anteriores à sua vinda histórica: “Cristo passou através de uma autêntica experiência da morte, compreendendo o momento final que 
geralmente faz parte da economia global: foi depositado no sepulcro". A afirmação da "descida aos infernos" é, pois,

uma conformação que sua morte foi uma morte real e não só aparente. Sua alma, separado do corpo, era glorificada em Deus, mas o corpo jazia no sepulcro, no estado de cadáver. Durante os três dias (não completos) passados entre o momento em que 'expirou' (cf. Mc 15,37) e a Ressurreição, Jesus experimentou o 'estado de morte', isto é a separação da alma do corpo, no estado e condição de todos os homens. Este é o primeiro significado das palavras 'desceu aos infernos"”.

A seguir, citando 1Pd 3,19, o Papa afirma que "esta parece ser uma representação metafórica da extensão da salvação de Cristo para aqueles que tinham morrido antes dele". O texto de $1 \mathrm{Pd}$ confirmaria assim, a concepção do Descensus como

cumprimento, até a plenitude, da mensagem evangélica da salvação /.../ Como morto - ao mesmo tempo como vivo 'para sempre' - Cristo tem 'poder sobre a morte e sobre os infernos' (cf. Ap 1,17-18). Nisto se manifesta e se realiza a pontência salvífica da morte sacrifical de Cristo, operadora da Redenção em relação a todos os homens: também os que morreram antes de sua vinda e de sua 'descida aos infernos', mas que foram alcançados por sua graça justificante. ${ }^{482}$

Também o tema da pregação aos mortos é interpretado pelo Papa neste mesmo sentido. Citando 1Pd 4,6, afirmou que "a Palavra do Evangelho e da Cruz alcança a todos, também aqueles pertencentes às gerações passadas, porque todos os que são salvos, são feitos participantes da Redenção, antes mesmo que ocorresse o evento histórico do sacrifício de Cristo no Gólgota" 483.

\footnotetext{
${ }^{482}$ http://www.vatican.va/holy_father/john_paul_ii/audiences/1989/documents/hf_jp-

ii_aud_19890111_it.html. Outra pequena menção ao tema do Descensus aparece também no discurso do papa João Paulo II aos peregrinos poloneses do Ano Santo da Redenção (21 abr 1984) “'Patì sotto Ponzio Pilato, morì e fu sepolto. Discese agli inferi': proprio oggi, attendendo la risurrezione di Cristo, in cui si compie la sua Pasqua, il suo passaggio, nutriamo una particolare venerazione per questo 'discese agli inferi', che la potenza della redenzione ha portato a tutti i discendenti di Adamo, che attendono la liberazione che conduca alla pienezza di vita" (http://www.vatican.va/holy_father/john_paul_ii/speeches/1984/april/documents/hf_jpii_spe_19840421_pellegrini-polacchi_it.html).

483 Idem
} 


\section{5 - O Catecismo da Igreja Católica.}

O Catecismo da Igreja Católica, promulgado pelo Papa João Paulo II, dedica quatro artigos à descida de Cristo aos infernos, retomando os principais pontos da doutrina referentes ao tema. Entende o artigo de fé primeiramente como a afirmação da realidade da morte de Jesus: "Este o sentido primeiro dado pela pregação apostólica à descida de Jesus à mansão dos mortos: Jesus conheceu a morte, como todos os homens, e foi ter com eles, por sua alma, à morada dos mortos" (art. 632) $)^{484}$.

Renunciando a qualquer doutrina apocatasta, o Catecismo ensina que, em sua descida junto aos mortos, Jesus libertou "os justos que O tinham precedido" não os condenados, como também não aboliu o inferno da condenação (art. 633).

O Catecismo retoma também os temas tradicionais da pregação aos mortos: "A descida à mansão dos mortos é o cumprimento, até à plenitude, do anúncio evangélico da salvação" (art. 634), e da vitória sobre as potências infernais (art. 635).

Por sua vez, o Compêndio do Catecismo da Igreja Católica, promulgado pelo Papa Bento XVI, irá resumir a doutrina, retomando a distinção entre o "inferno dos condenados" e os "infernos" aos quais desceu Jesus, bem como explicitando que essa descida se deu com a alma de Jesus, unida à sua Pessoa divina:

Os «infernos» (não confundir com o inferno da condenação) ou mansão dos mortos, designam o estado de todos aqueles que, justos ou maus, morreram antes de Cristo. Com a alma unida à sua Pessoa divina, Jesus alcançou, nos infernos, os justos que esperavam o seu Redentor para acederem finalmente à visão de Deus. Depois de com a sua morte, ter vencido a morte e o diabo «que da morte tem o poder» (Heb 2,14), libertou os justos que esperavam o Redentor, e abriu-lhes as portas do Céu ${ }^{485}$.

${ }^{484}$ CEC 632, Tradução nossa, pois a tradução brasileira ("Jesus conheceu a morte, como todos os homens, e foi ter com eles à morada dos mortos") não corresponde aos textos latinos (editio typica: "anima Sua") e francês (língua original: "par son ame"), nos quais se afirma explicitamente a ida da "alma" de Cristo à morada dos mortos.

${ }^{485}$ CCEC, 125. 


\subsection{Teólogos de língua alemã}

A descida de Cristo a morada dos mortos na perspectiva alemã, na primeira metade de nosso século, mostrou uma discreta e global atenção teológica sobre o nosso tema proposto. Nestes últimos anos, todavia, as contribuições se reencontraram mais facilmente no contexto da produção cristológica ou no estudo mais amplo sobre a soteriologia cristã. Entre os teólogos de língua alemã podemos citar Hans Urs von Balthasar, Ratzinger, Rahner e Hans Kung que contribuíram no desenvolvimento da doutrina da descida de Cristo à mansão dos mortos

\subsection{1 - Hans Urs von Balthasar.}

O tema do descensus ad inferos ocupa um lugar de destaque no pensamento de Hans Urs von Balthasar, sendo o corolário de sua teologia kenótica, o núcleo estruturador de seu pensamento. O tema vem apresentado em sua obra Teologia dos três dias, que aparece reproduzida no Compêndio de Dogmática histórico-salvífica Mysterium Salutis ${ }^{486}$, condensado no artigo “Descida ao Inferno", no volume IV de seus Ensaios Teológicos ${ }^{487}$.

Aplicando o princípio da reciprocidade entre a Trindade econômica e a Trindade imanente, von Balthasar faz derivar a kenosis histórica do Filho do mistério da auto-doação eterna na Trindade: "O despojamento de Deus (na Encarnação) tem sua possibilidade ôntica no eterno esvaziamento de Deus, isto é, em sua doação tripessoal" ${ }^{488}$. Tal posição, ainda que possa ter seu valor (e fundamento bíblico, cf. Jo 8,38), não deixa de apresentar dificuldades, correndo o risco de transformar o mistério da redenção em uma "teodicéia", na qual tudo

\footnotetext{
486 Como não pudemos ter acesso ao texto original, no presente trabalho utilizamos a tradução brasileira de Mysterium Salutis III/6, Editora Vozes Ltda, Petrópolis, 1974 (tradução de D. Mateus Rocha osb), que cotejamos, quando necessário, com a tradução espanhola Mysterium Salutis. Manual de Teologia como Historia de la salvación, Ediciones Cristiandad, Madrid, 1972 (tradução de Guillermo Aparicio y Jesús Rey), bem como com a tradução espanhola de Teologia de los tres dias, Ediciones Encuentro, Madrid, 2000 (trad. José Pedro Tosaus).

487 BALTHASAR, H. U. v., Descenso al Infierno, in Ensayos Teológicos IV. Pneuma $e$ Instituición. Madrid. Ediciones Encuentro e Ediciones Cristiandad, 2008, p. 319-330.

${ }^{488}$ BALTHASAR, H. U. v., Mysterium Salutis, III/6, p. 19 (cotejado com a tradução espanhola El misterio Pascual. In:FEINER, J., LÖHRER, M. (eds.), Mysterium Salutis. Manual de Teología como Historia de Salvación, III, Madrid, 1969).
} 
ocorre de modo necessário ${ }^{489}$ (risco esse do qual a obra de von Balthasar parece não conseguir libertar-se completamente ${ }^{490}$ ).

E é no descensus ad inferos que a kenosis do Filho de Deus encontra seu ponto máximo:

Se o Pai deve ser considerado como criador da liberdade humana - com todas as suas consequências previsíveis - então originariamente o juízo lhe pertence, e consequentemente o inferno, e se ele enviou o seu Filho ao mundo para salvar e não para condenar, e se, para esta função lhe entregou todo o julgamento (Jo 5,22 ), então ele devia introduzi-lo como encarnado, também no inferno (como última consequência da liberdade criada) $)^{491}$.

Ao expor seu pensamento, von Balthasar segue os relatos bíblicos da Paixão. Em nossa análise, prescindindo dos textos em que ele apresenta a vida de Jesus como orientada para a cruz $^{492}$, e os textos sobre a Eucaristia ${ }^{493}$, passamos logo à cena do Horto das Oliveiras, que apresenta maior ligação com nosso tema, pois é interpretada com a mesma chave de leitura com que depois se interpreta a "ida à morada dos mortos". Segundo nosso autor, no Horto já aparece a

489 Balthasar ha intentado fundar la kénosis histórica de Cristo en una kénosis intratrinitaria del Hijo. Si con este término quiere sugerir que el Hijo es relación procedente del Padre y ordenada a él, todo recepción y todo respuesta, y que la obediencia del Hijo encarnado corresponde a su filiación trinitaria prolongando ese trinitario «ser para el Padre» como un «ser para los hombres» en el mundo, y compartiendo su destino hasta el límite de bajar a los infiernos para superarlos, entonces hasta cierto punto debemos estar de acuerdo. Pero hablar sin más de una kénosis intratrinitaria en sentido estricto carece de fundamento bíblico y es una aplicación ilegítima del principio de reciprocidad entre la Trinidad inmanente y la Trinidad económica. Dios revela y realiza en el mundo lo que es su vida trinitaria; pero la existencia encarnada del Hijo tiene elementos de novedad, libertad e historia que son consecuencia del pecado humano, y que no preexisten ni tienen su fundamento en la vida trinitaria. La negatividad no pertenece al ser de Dios, y en ese sentido el desgarro, Riss (Hegel), del mal, del dolor y de la muerte no pasan por él. Dios entra en el devenir, el dolor y la muerte, pero como expresión no de su ser en necesidad sino de su libertad en amor. Sin embargo, frente a Rahner tiene razón Balthasar al subrayar las condiciones concretas de la historia humana y su repercusión sobre el Hijo encarnado. La encarnación ha sido «en semejanza de la carne de pecado». «Dios ha destruido al pecado por el pecado en la muerte» [Rom 8,3-6] CARDEDAL, O. G. de, Cristología, 2001, 397-398.

${ }^{490}$ Veja-se, a título de exemplo, a afirmação de Von Balthasar a propósito do relato do Getsêmani: ao contrário do relato da tentação, em todo este acontecimento em parte nenhuma se fala do diabo. Toda a história da paixão o deixa à margem. Ela se passa entre o Pai e o Filho. Aquilo que interessa é a aceitação do pecado do mundo (Jo 1,29). Com este acontecimento, a potência adversária foi «desarmada» ( $\mathrm{Col} 2,15)$ - sem um combate expresso com a mesma Mysterium Salutis, III/6, 70

${ }^{491}$ Mysterium Salutis, III/6, p 119. Nas traduções espanholas (Mysterium Salutis, p. 755 e Teología de los tres días, p. 151), em lugar de "condenar" usa-se o verbo "juzgar".

${ }^{492}$ BALTHASAR, H. U. v., Teología de los tres días, pp. 77-82.

${ }^{493}$ Ibid. pp. 89-86. 
disposição de Jesus de solidarizar-se com os pecadores, sofrendo em lugar deles, a "pæna damni". No Horto Jesus sofre

com o 'pavor' ( $\dot{\kappa} \kappa \theta \alpha \mu \beta \varepsilon \tilde{\imath} \sigma \theta \alpha \iota)$ e a 'angústia' da 'solidão' ( $\dot{\alpha}-\delta \eta \mu o v \varepsilon \tilde{\imath} v: M c$ 14,33). Solidão com respeito a Deus que se afasta, mas ainda não desapareceu e ao qual Jesus se dirige com a invocação terna e suplicante de 'papai', abba, mas com o qual não há outra comunicação que o anjo lucano que conforta para o sofrimento, ou, nos paralelos joânicos, a voz que ressoa confirmatória desde o céu, que afirma a glorificação do Pai (não de Jesus!) através da Paixão ${ }^{494}$.

Para Jesus, "a angústia do Horto das Oliveiras é um tal com-padecer com os pecadores que a perda de Deus que esperava realmente a estes (poena damni) é assumida pelo amor humanado de Deus em forma de timor gehennalis: ao ser 'sobrecarregado' com o pecado do mundo, Jesus já não se distingue em seu destino dos pecadores /.../ e experimenta desse modo a angústia e o pavor que, por direito, haveriam de sentir aqueles" ${ }^{\$ 495}$. Afirma, desse modo, que no Horto Jesus parte para enfrentar a morte ignominiosa, sem qualquer outro sentido que a obediência à vontade do Pai por si mesma:

Se os primeiros anúncios da Paixão tomam explicitamente em consideração a ressurreição ao terceiro dia (por conseguinte, a exaltação depois do rebaixamento), no Horto não há nada que aponte adiante, à glorificação. Se desde as declarações anteriores, e desde os textos posteriores que as explicam, parece possível enxertar o destino de Jesus no esquema judaico vetero-testamentário do 'justo sofredor' que posteriormente é exaltado e recompensado, na agonia do Horto - minha vontade, tua vontade - é apagado todo esquematismo ante o único e de importância excepcional. Tampouco as categorias da teologia martirial do judaísmo tardio podem aclarar nada nesse caso, pois as múltiples motivações e efeitos repletos de bênçãos do martírio, bem como a atitude concretamente éticoheróica do mártir, ficam aqui fora do horizonte de visão. Todo 'sentido' fica inexoravelmente reduzido a humilde preferência da vontade do Pai por si mesma. Nada se fala aqui de que a esperança na imortalidade da teologia apocalíptica e sapiencial tardias atenue, de antemão, o aguilhão da morte $(\mathrm{Sb} 2,24 ; 3,2 \mathrm{~s})^{496}$.

Recorrendo a categorias vetero-testamentárias ${ }^{497}$, von Balthasar fala da prisão e condenação de Jesus, como uma "entrega" que Deus faz de seu Filho; como fizera com seu povo infiel, Deus Jesus aos poderes da morte:

\footnotetext{
${ }^{494}$ Ibid. p. $86-87$.

495 Ibid. p. 90.

${ }^{496}$ Ibid. p. 91.

${ }^{497}$ En la Antigua Alianza, no solo se predice el sufrimiento interior de Cristo, sino que éste se vive de antemano en múltiples maneras. /.../ El abandono del pueblo por parte de Dios es, por tanto, auténtico y único en su género, pues auténtica y única en su género es también la presencia de Dios que sólo Israel ha conocido en medio de él. (ibid. 63-64).
} 
A teologia da entrega só se pode elaborar em perspectiva trinitária. O fato de que Deus «entrega» seu Filho «é uma das afirmações mais inauditas do Novo Testamento; devemos entender a 'entrega' no sentido pleno, e não suavizá-la convertendo-a em 'missão' ou 'dom'. Neste caso sucedeu o que Abraão não teve que fazer com Isaac: Cristo foi abandonado pelo Pai de forma intencionada ao destino da morte; Deus o lançou fora, aos poderes da perdição, chame-se a estes homens ou morte... 'Deus fez de Cristo pecado' (2Cor 5,21), Cristo é o maldito de Deus... Neste ponto se explicita que a theologia crucis não pode ser mais radical» ${ }^{498}$.

Mesmo reconhecendo admite uma "entrega" que o Filho faz de si mesmo, von Balthasar insiste que a interpretação desta auto-entrega "não pode se isolar como um elemento independente, porque, do contrário, estaremos a um passo de perder o horizonte escatológico e resvalar para a teologia martirial”499.

Desse modo, a crucifixão de Jesus é interpretada por von Balthasar como um ato judicial de Deus, que castiga a Cristo como maldito, objeto de sua cólera: “A cruz é, antes de tudo, realização do juízo divino sobre o 'pecado' compendiado no Filho, posto à luz e sofrido por ele (2Cor 5,21); o envio do Filho se deu na

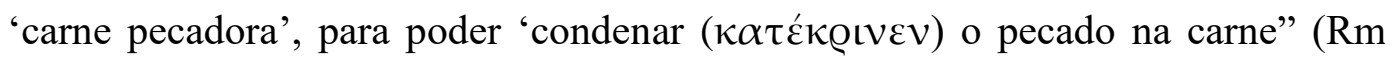
$8,3)^{» 500}$. Respeitando a justiça devida à sua aliança, Deus "deve levar a sério seu companheiro de aliança e reconduzi-lo com juízo, correção e castigo, à justiça que o rebelde não pode restaurar por sua própria conta"501.

Nas palavras pronunciadas por Cristo na cruz, von Balthasar vê a confirmação de sua tese. Em sua interpretação, porém, toma o "grito de abandono" (Mc 15,34 // Mt 27,46) como determinante da vivência pessoal de Jesus (praticamente prescindindo das demais palavras, "palavras da cruz"):

À luz da explicação teológica de João e Paulo, as descrições da Paixão recebem em conjunto seu perfil teológico. Primeiramente as palavras. Em primeiro lugar se encontra o grito de abandono, em Marcos a única palavra pronunciada na cruz, que somente na arbitrária ordenação de uma harmonia dos evangelhos fica relegada à condição de 'quarta palavra' 502 .

\footnotetext{
${ }^{498}$ Ibid. p. 96.

${ }^{499}$ Ibid.

${ }^{500}$ Ibid. p. 102. A esa cólera debe exponerse el Hijo en la Pasión. Él debe poner fin escatológico a la cólera terrible, de fundamento divino, que arde a lo largo de todo el antiguo Testamento y que finalmente consumió a la Jerusalén infiel en el propio fuego de la gloria (Ez10,2). (Ibid. 119).

${ }^{501}$ Ibid. p. 103.

${ }^{502}$ Ibid. p. 107.
} 
Esta é interpretada por von Balthasar não no contexto do Sl 22,2 como usualmente se faz ${ }^{503}$, mas como expressão da vivência anímica de Jesus, à luz dos relatos das experiências dos místicos, como abandono por parte de Deus ${ }^{504}$.

Mas é com sua compreensão peculiar, do Descensus, que von Balthasar leva ao extremo sua compreensão da kenosis do Filho de Deus. Tomando o Sheol "no sentido vetero-testamentário clássico, deixando de lado as especulações do judaísmo tardio, com influências persas e helenistas" $" 505$, nosso autor entende o estado dos mortos como total passividade ${ }^{506}$ (os "refaim" que apresentamos acima $^{507}$ ) e rejeita qualquer atividade de Cristo no além:

o que primeiramente se deve aqui considerar é que Jesus está realmente morto, e o está porque se fez realmente homem conosco, filhos de Adão; que, portanto, não aproveita o 'breve' tempo em que está morto para realizar todo tipo de 'atividades' no além (como frequentemente se pode ler nos livros de teologia) ${ }^{508}$.

Desse modo, recusando como mitológica a teologia do Descensus como "vitória sobre os poderes infernais", admite apenas a "pregação aos mortos"509, e esta entendida a seu modo: "Não há dificuldade em entender este 'ir aos espíritos encarcerados' primordialmente como um 'estar entre', e a 'pregação', do mesmo modo, primordialmente como o anúncio da 'redenção' ativamente sofrida e

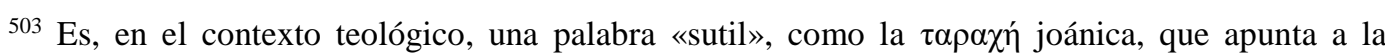
culminación única de Jesús, y en modo alguno al comienzo de la recitación de un salmo que termina con la glorificación del que sufre y requiere una interpretación en el contexto sálmico (Ibid. 107).

${ }^{504}$ En este caso tiene plena vigencia el principio básico que Ireneo estableció contra los gnósticos, según el cual Cristo no podía exigir de sus discípulos ningún padecimiento que él como maestro no hubiera padecido en su persona (Adv.. Haer. III,18,5-6). (Ibid p. 107).

505 BALTHASAR, H. U. v.,Teología de los tres días, 139-140.

${ }^{506}$ Cuando atribuimos a los muertos formas de actividad nuevas, pero que prolongan las terrenas, con ello no expresamos sólo nuestra perplejidad; lo hacemos en contra de una convicción mejor, que nos dice que estar muerto no es un acontecimiento parcial, sino que afecta al hombre como un todo - aun cuando este principio no considere extinguido al sujeto -, y que este estado significa principalmente dejar atrás toda actividad espontánea, y por tanto implica pasividad, estado en el cual quizás se saca misteriosamente la suma de la actividad vital ya concluida. Ibid, 129.

507 Cristo pertenece ahora a los refá'im, los «sin fuerzas»; no puede entablar una lucha activa contra las «fuerzas del infierno», tampoco «triunfar» subjetivamente, cosa que a su vez presupondría vida y fuerza. (Ibid. p. 149).

508 Ibid. Por isso rejeita, inclusive, a expressão "descida aos mortos": Pero, ¿acaso el «descendit» no expresa claramente una actividad, especialmente si se toma como marco conceptual de otras actividades determinadas de Jesús en el reino de los muertos, actividades que se consideran consecuencia inmediata de aquélla? ¿No debería bastarnos hablar de «estar con los muertos»? (Ibid. p. 131).

509 Todo esto es sólo la lógica del morir humano llevada hasta el final, y no dice nada sobre un «descenso», y menos aún sobre una «lucha» o incluso sobre un «victorioso desfile triunfal» de Cristo por el Hades /.../ No lo olvidemos: entre los muertos no hay comunicación viva. En este caso, solidaridad significa «estar solo con» (Ibid. p. 143). 
efetuada através da cruz de Jesus vivo, e não como uma atividade nova, separada da primeira" ${ }^{510}$.

Mas, ainda mais complexa é a afirmação que Cristo, em solidariedade aos pecadores, sofre no inferno a pena dos condenados:

O castigo imposto à humanidade 'pré-cristã' devido ao 'pecado original' prescindimos aqui do pecado pessoal - é de jure definitivo: é a poena damni, privação da visão de Deus" 511 . "Se mediante a graça de Cristo que atua antecipadamente, aqueles que viveram no amor antes dele não experimentaram toda a 'poena damni' verdadeiramente merecida (porque o esperam à luz da fé, do amor e da esperança), quem, então, a experimenta realmente, senão o próprio Redentor? Não é, precisamente, esta desigualdade a conseqüência última da lei da solidariedade?"512 "Partindo do que acabamos de dizer, resulta inevitável pensar que o Redentor, ao poupar os mortos, em sua solidariedade com eles, a experiência plena do 'estar morto' (como poena damni) - de modo que um raio celestial de luz de fé, de amor e de esperança iluminou desde sempre o 'abismo' tomou sobre si em representação vicária a dita experiência inteira. Assim ele se mostra como o único que, indo além da experiência comum da morte, mediu a profundidade do abismo ${ }^{513}$.

Em outra obra, Teodramática, Von Balthasar leva suas afirmações ainda longe: "O Crucificado não padece simplesmente o inferno merecido pelos pecadores; padece algo que vai mais além e abaixo deste: um abandono de Deus na pura obediência de amor da que só o Filho é capaz, que abarca qualitativamente todo inferno possível"514.

A consequência quase inevitável das ideias de von Balthasar relativas ao Descensus (e do conjunto de sua teologia kenótica) é a aceitação da apocatástasis. Solidarizando-se com os condenados, Cristo concede efetivamente a salvação a todos:

\footnotetext{
${ }^{510}$ Ibid. p. 131. Notar que von Balthasar fundamenta biblicamente o Descensus, entendido como pregação aos mortos, na controvertida passagem de 1Pd 3,18-19, que já tivemos oportunidade de analisar, e esta entendida à luz do livro apócrifo de Henoc; como vimos, estas duas opções são bastante questionáveis.

${ }^{511}$ Ibid. p. 143.

512 Ibid. p. 144.

${ }^{513}$ Ibid. p. 145.

${ }^{514}$ BALTHASAR, H. U. v.,Teodramática 5, Madrid: Encuentro Ediciones, 1997, p. 252.
} 
o inferno, no sentido neo-testamentário, depende do acontecimento Cristo; mas se Cristo não sofreu somente pelos eleitos, mas por todos os homens, também assumiu precisamente o 'não escatológico' destes ao acontecimento salvífico protagonizado por ele; então há de se dar ao Cusano fundamentalmente a razão, seja qual for o modo como se descrevem os particulares da experiência do Sábado santo. A dita experiência não tem porque ser outra coisa que aquilo que exige uma solidariedade, considerada seriamente, no šeol, um šeol não iluminado por luz alguma de redenção, pois toda luz de redenção procede unicamente do solidário até o final. E ele pode comunicá-la somente porque, em função de representação vicária, renunciou a ela ${ }^{515}$.

Ao utilizar os textos de 1Pd 3,18-20 e 4,6 entendidos como pregação de Cristo nos infernos, von Balthasar abre caminho para se admitir uma salvação oferecida após morte: “a pregação da Boa Nova aos mortos em (1Pd) 4,3 é um acontecimento no além, que estende até lá o efeito do fruto do sofrimento de Cristo na carne, seja qual for o modo como se entenda aqui a idéia de uma conversão depois da morte" ${ }^{\text {516. }}$. Mais ainda, interpretando $1 \mathrm{Pd}$ 3,18-20 à luz do livro apócrifo de $\mathrm{Henoc}^{517}$, nosso autor ameaça chegar à doutrina da apocatástais mais radical, que admite a salvação inclusive dos demônios ${ }^{518}$, o que ele, porém, parece negar em outras de suas obras ${ }^{519}$.

Após esta apresentação sumária do pensamento de von Balthasar, em relação ao nosso tema, da Descida de Cristo à morada dos mortos „uma avaliação crítica faz-se necessária.

- O modo como ele utiliza as Sagradas Escrituras para fundamentar suas afirmações parece-nos questionável. Com relação aos relatos, ao pretender

\footnotetext{
${ }^{515}$ BALTHASAR, H. U. v., Teología de los tres días. p. 148.

516 Ibid. p. 137.

${ }^{517}$ Caben pocas dudas de que el teologúmeno del viaje de Cristo al Hades tiene como modelo el mito de Henoc que acabamos de describir. Hasta los espíritus desobedientes metidos en la oscura mazmorra de la fortaleza del mundo inferior llega una vez más un mensajero de Dios con una embajada divina. Pero, mientras que Henoc debía hacerles saber la nueva de la imposibilidad del perdón, la nueva de este otro mensaje es diferente: Buena Nueva (4,6). Así, la doctrina de la predicación de Cristo en el Hades quiere expresar que el Justo murió por los injustos $(3,18)$; su morir expiatorio ha alcanzado la salvación incluso para los perdidos sin esperanza» (Ibid. p. 138139).

518 /.../ estas acotaciones ponen de manifiesto como algo sumamente verosímil que la predicación de la Buena Nueva a los muertos en 4,6 y la proclamación a los espíritus encarcelados en 3,19 son el mismo acontecimiento, con lo cual en estos «espíritus» se puede seguir viendo, con BO REICKE, los poderes cósmicos de la época anterior al diluvio juntamente con los hombres dominados por ellos. (Ibid. p. 137).

519 Veja-se, por exemplo, o capítulo X (Satanas) da obra Tratado sobre el infierno. Compendio (Valencia, 1999, EDICEP, tradução de Salvador Castellote Cubells) que von Balthasar escrever em resposta às acusações de apocatasta que lhe foram feitas.
} 
concluir do texto das Escrituras, qual era a vivência interior de Jesus no Horto das Oliveiras ou na cruz, encontramos, de fato, dificuldades muito graves. Os evangelhos, com efeito, não podem ser tomados como biografias de Jesus, a ponto deles se concluirem sobre suas disposições interiores no momento da Paixão;

- Ainda mais, o pensamento de von Balthasar, considerado em si mesmo, não aparece isento de contradições. Com efeito, afirmar que Jesus enfrentou a morte sem qualquer consideração à glorificação que se seguiria, sem referência inclusive à teologia do martírio, equivale também a negar todo sentido soteriológico à sua intenção. Ele teria experimentado a morte do condenado, que morre sozinho, para si somente, e sem nenhum tipo de sentido. Ora, como nos parece suficientemente demonstrado por J. Jeremias, Jesus mesmo conferiu sentido salvíficos expiatórios aos sofrimentos e à morte que havia de padecer, entendendo-os à luz das Escrituras, particularmente de Is 53, o quarto canto do Servo de Javé ${ }^{520}$;

- A escolha da compreensão da "morada dos mortos" no "sentido veterotestamentário clássico", como completa inatividade, ignorando a evolução posterior parece-nos arbitrária. Por que a "morada dos mortos" deve ser entendida preferencialmente aos moldes das fases mais primitivas do antigo Testamento? Tal entendimento opõe-se à compreensão demonstrada pelo próprio Jesus em suas parábolas (cf. Lc 16, 19-31);

- A ideia de Jesus, após a morte, experimentando a poena damni, não encontra suficiente apoio na Sagrada Escritura e, muito menos, na tradição patrística. Pelo contrário, Agostinho, quando diz que Jesus desceu ao inferno dos condenados, faz questão de afirmar que o fez para ali atuar como Salvador:

\footnotetext{
${ }^{520}$ Após um longa exposição, o autor afirma: Finalmente hay que mencionar a Lc 23,34, donde Jesús intercede sobre La cruz: 'Padre, perdónales, porque no saben lo que hacen'. Esta oración es una añadidura al texto más antiguo, pero está basada en una antigua tradición, como lo demuestran la forma (dios tratado como 'Padre', Abba), y el contexto (la intercesión por los enemigos). Nuevamente, tenemos en esta oración una interpretación implícita de la muerte de Jesús. Porque Jesús la ofrece en lugar del voto expiatorio: 'Que mi muerte expie todos mis pecados', que un condenado debía pronunciar antes de su ejecución. Jesús aplica la virtud expiatoria de su muerte no a si mismo, como era costumbre, sino a sus ejecutores. Aquí nuevamente el fondo lo encontramos en Is 53, que termina con aquellas palabras: 'e intercedió por los pecadores' (v. 12). JEREMÍAS, J., Abba. El mensaje central del Nuevo Testamento, 1999, p. 288.
} 
"nenhuma causa se apresenta para que o Salvador ali descesse, senão para salvar das dores" $" 521$.

Se num primeiro momento, tal afirmação parece ter origem no já citado pensamento de Calvino, que afirmava a descida ao inferno como o extremo abandono de Deus sofrido por Jesus ${ }^{522}$, a influência mais imediata nós a encontramos nas experiências místicas de Adrienne von $\mathrm{Speyr}^{523}$, de quem von Balthasar foi diretor espiritual.

$521 / . . . /$ nulla causa occurrit cur illo credatur venisse Salvator, nisi ut ab eius doloribus salvos faceret. (Ib. 164,8).

${ }^{522}$ Instituições da Religião Cristã, II, 16, 10-11. "As Institutas ou Tratado da Religião cristã. Edição clássica” (http://www.scribd.com/doc/6915088/Joao-Calvino-Institutas-2-traducao-dolatim, Acessado em 07/01/2011 17:26)

${ }^{523} \mathrm{O}$ próprio von Balthasar preparou para a revista Communio uma edição de textos de Adrienne von Speyr relativos à descida de Cristo aos infernos "Après la mort (A. gît comme morte sur la chaise longue). D'abord le tressaillement au moment du coup de lance. Ensuite une pause et une suspension : reddition de la mission au Père dans le 'Paradis' (où le larron peut demeurer). Puis soudain A. 'commençait à s'enforcer, dans un abîme', elle avait l'impression de tomber sans fin, toujours plus rapidement. Elle 'tombe jusqu'au fond de l'enfer'. Et ceci dans um état 'de mort'. Il n'y a plus des souffrance physique, mais une autre forme, encore plus profonde d'intémporalité. 'La durée est suspendue'. Ainsi, 'dans l'enfer rien ne peut être du passer'. 'Tout n'est que maintenant'. 'Alors l'enfer est-il ce qui est plus contraire au ciel, où il y a, dans l'éternité divine, l'accomplissement de tout le temps ? Dans l'enfer, l'intemporalité est un état interminable, où l'on ne peut plus agir, l'opression du poids du péché, le caractère définitif et le présent du non-sens'. 'L'abandon est devenu la totale aliénation'. Tout le contact humain est exclu. 'La foi, la charité et l'espérance sont inacessible'. A. dit et fait les choses quotidiennes comme 'un mécanisme'. Elle est 'comme une poupée, ou mieux : comme un catatonique qui prend toute les positions qu'un autre lui donne'. L'homme dans l'enfer, dit-elle, 'n'a plus rien d'infini, il est pure finitude'. Aussi ne pourrait-il pas se confesser, tout au plus pourrait-il 'se laisser psychanalyser à l'infini'. Si quelque chose se meut, si on se meut, c'est alors sans aucun sens de la direction; ce qu'on laisse derrière soi revient sur soi. Et rien n'est términé, il n'y a aucune issue'. 'On avance dans l'éternité de l'enfer, mais plus on avance, plus l'éternité se trouve devant vous. C'est ce qui est le plus contraire à l'éternité du ciel'. En chaque seconde que je vis en enfer, les années que je dois y passer se multiplient. Naturellement, ce n'est là qu'une image humaine pour l'état en quéstion, pour l'absence toujours plus grande espoir'. C'est 'l'horreur achevée'. Mais A. n'est pas ici comme 'damnée', elle se trouve dans une marche paradoxale à la suite du Seigneur ; elle doit chercher les 'traces' du Seigneur, dont elle sait qu'il passe ou est passé par ici, mais les traces restent invisibles : dans l'enfer, le Christ mort n'agit plus. 'Quand on suite sur la terre le Seigneur ou ses saints, on trouve partout des traces ; des traces de la grâce, des traces de la présence passée ou de la parole passé'. Dans l'enfer, non. 'On tente de suivre ses traces, et on remarque que ce n'est pas possible'. 'On marche sur les pas du Seigneur, et pourtant on ne les connaît pas'. 'Inutilité', tel est le nom de cet état». (...) «'À la créacion du monde, Dieu est entrée dans le chaos, afin de le mettre en ordre'. 'D'un jour de la créacion à un autre jour de la créacion, on le voit se dissiper'. Mais du fait que Dieu donne à l'homme en pechant, peut faire pénétrer dans l'ordre. 'La liberté du choix est quelque chose de neutre, et par là apparenté au chaos'. 'L'apocalypse est pleine de preuve démontrant que le (second) chaos existe ; il peut être descellé'. Et puisque l'homme l'a produit, Dieu 'pénètre de nouveau dans le chaos, maintenant non plus en tant que Créateur, mais en tant que destructeur', en tant que redempteur. L'enfer est le second chaos séparé du monde remis en ordre à la Croix. Ce que le Créateur a séparé en mettant de l'ordre était 'de l'eau claire comme du crystal'; ce qui est séparé du pécheur est 'le pur contraire', le boubier comme 'produit résiduel'. 'Le chaos est ce dont quelque chose est né, l'enfer est ce dans quoi quelque chose naît'. 'Si un homme avait été là lors de la créacion du monde, il n'aurait pas 
É conhecido por todos que a teologia do Sábado santo em BALTHASAR está inspirada nas revelações privadas de ADRIENNE VON SPEYR. Sua dirigida experimentou, após sua conversão ao catolicismo, fenômenos místicos durante a celebração da Semana Santa. Estas experiências versavam sobre a ida de Cristo ao lugar da condenação, ao inferno. BALTHASAR deu "forma teológica" a estas revelações e explicou sistematicamente como elas poderiam ser integradas no dogma cristão ${ }^{524}$.

\title{
3.6.2 - Joseph Ratzinger.
}

\author{
Em seu comentário ao Símbolo Apostólico, escrito em $1968^{525}$, Introdução \\ ao Cristianismo, Joseph Ratzinger faz uma sucinta apresentação do artigo "desceu \\ aos infernos". Mesmo sendo claramente perceptível a afinidade de termos com o \\ pensamento de von Balthasar, as afirmações do futuro Pontífice apresentam \\ correções importantes ao pensamento do teólogo suíço.
}

Após sustentar a dificuldade do tema, ("talvez nenhum artigo do Credo esteja mais longe de nossa consciência atual do que este" ${ }^{\text {526 }}$ ), e sua escassa

tenu pour possible que Dieu puisse créer un ordre à partir du chaos ; pas davantage l'humanité souffrante ne croit que le Seigneur au Calvaire puisse créer un ordre du salut. Nous devons être déjà rachetés pour croire à la possibilité de la rédemption du monde par la Passion du Seigneur'. 'L'enfer formé doit être transformé en chaos informe' »; "L'obéissance du Fils incarné était depuis toujours le mode sotériologique de son don éternel d'amour au Père. Si la mission de Jésus 'accomplie' avec la mort sur la Croix, et s'il rend au Père l'Esprit qui l'a envoyé, l'obéissance du Seigneur mort est l'objet d'une sur-exigence ultime, inattendue et imprévisible. 'Dans le calice est toujours mis encore du nouveau, sans considération de ce qu'il est déjà plein à déborder'. C'est d'un côté, une obéissance sans vision possible, puisque le Fils doit chercher le Père là où il ne peut pas être, dans ce qui est réjeté par Dieu. De l'autre côté, ce n'est plus une obéissance active, 'il ne lui reste plus de force productive', 'il est mené plutôt qu'il ne va lui-même', il est devenu 'plus fonction', 'une contrainte que l'on s'impose à soi même, ou plutôt : que l'on vous a imposée'. Il est pure objectivité, de même que ce qui est éprouvé dans l'enfer, le péché du monde, est pure objectivité; 'entre le Seigneur et le péché, il n’y a aucune loi qui règne, mais une simple confrontation sans loi'. Ainsi n'y a-t-il pas des phases, pas d'élaboration, mais en toute aspect de ce qui est éprouvé, il y a toujours le tout, de même que l'expérience met en jeu toute l'obéissance. Ce qui doit être assumé, c'est le mystère incompréhensible du péché dans l'enfer'. Devoir assumer ce mystère et ce qu'il a de 'contradictoire' dans l'intemporalité, engendre 'l'angoisse d'enfer' spécifique, c'est 'l'inhumain' absolu. Le cri sur la Croix était un abandon subjectif au milieu de l'obéissance accomplie, l'abandon dans l'enfer est purement objectif, c'est un 'au délà de l'obéissance' ». SPEYR, A. von, L'expérience du Samedi Saint. In : Communio (edição francesa) VI, I (1981), pp. 64-68.

${ }^{524}$ SANTAMARIA LANCHO, J.A.., Un estudio sobre la soteriología Del dogma del Descensus ad ínferos: 1 Pe 3,19-20a y la tradición sobre "la Predicación de Cristo en los Infiernos". 2007. 200 p. Tese (Doutorado em Teologia) Fakultät der Ludwig-Maximilians-Universität München, München, 2007., p. 715.

${ }^{525}$ A obra foi publicada originalmente em alemão, com o título Einführung in das Christentum, por Kösel-Verlag (München). Seguimos a tradução Introdução ao Cristianismo. Preleções sobre o Símbolo Apostólico. Herder, São Paulo 1970, tradução de Pe. José Wisniewski Filho.

${ }^{526}$ RATZINGER, op. cit. 246. 
fundamentação bíblica ${ }^{527}$, utiliza (como von Balthasar) o grito de Jesus na cruz ("Meu Deus, por que me abandonaste?") como chave de interpretação da experiência de Jesus. Interpreta-o, porém, (diferente de von Balthasar), no contexto do S1 22 [21],2, como "prece brotada da miséria mais profunda da treva de Deus", que, termina, porém, “com um louvor à divina grandeza”,528.

Mostrando a relação do termo "inferno" com o conceito hebraico de sheol/morte ${ }^{529}$ Ratzinger afirma, pois, que o artigo quer expressar

que Cristo atravessou as portas de nossa solidão derradeira, que em sua paixão desceu ao abismo do nosso abandono. Onde voz alguma está em condição de alcançar-nos, ali ele se encontra. Com isto o inferno foi vencido, ou, mais exatamente: a morte, que antes era inferno, não o é mais. Ambas as coisas não são mais o mesmo, porque em seu centro está a vida, porque em seu meio habita o amor. Só o excluir-se, o fechar-se voluntário é o inferno, ou, no dizer da Bíblia, é morte segunda (por exemplo Ap 20,14) ${ }^{530}$.

Assim ele interpreta a imagem patrística da libertação dos mortos, bem como o texto de Mt 27,52.

Como se pode facilmente perceber, é aceita de Von Balthasar, além da fundamentação escriturística, a ideia da solidariedade de Cristo com os mortos, sem chegar aos extremos da afirmação de Jesus ter sofrido as penas dos condenados, ou os extremos da salvação apocatásta.

Como já foi apresentado, eleito Sumo Pontífice, nosso autor fez diversas referências ao tema, em uma delas com referência quase literal à sua antiga obra (cf. meditação proferida em Turim de 02 de maio de 2010).

Após assumir o ofício primacial, o Papa Bento XVI referiu-se mais de uma vez ao nosso tema. Na homilia da Vigília Pascal de 2007, o Descensus é apresentado em perspectiva soteriológica:

\footnotetext{
${ }^{527}$ Ratzinger reconhece, com razão, que "os poucos textos em que a Escritura parece falar algo a respeito (1Pdr 3,19s; 4,6; Ef 4,9; Rm 10,7; Mt 12,40; At 2,27.31) são tão difíceis de compreender que facilmente se pode interpretá-los em muitos sentidos" (Op. cit. 246).

${ }^{528}$ Op. cit. 249.

529 /.../ o Antigo Testamento conhece uma palavra apenas para conotar inferno e morte, a palavra sheol: porque ambas as coisas são idênticas para o Antigo Testamento. A morte é solidão simplesmente. Mas a solidão à qual não pode chegar o amor é o inferno. (Op. cit. 253).

${ }^{530}$ Op. cit, 253.
} 
No Credo professamos a respeito do caminho de Cristo: 'Desceu à mansão dos mortos'. O que acontece então? Visto que não conhecemos o mundo da morte, podemos representar este processo de superação da morte somente com imagens que permanecem sempre pouco apropriadas. Porém, com toda a sua insuficiência, elas nos ajudam a entender algo do mistério. A liturgia aplica à descida de Jesus na noite da morte a palavra do S1 24 [23]: 'Levantai, ó pórticos, os vossos dintéis, levantai-vos, ó pórticos eternos!' A porta da morte está fechada, ninguém dali pode voltar para trás. Não existe uma chave para esta porta férrea. Cristo, porém, possui a chave. A sua Cruz abre de par em par as portas da morte, as portas irrevogáveis. Elas agora já não são intransponíveis. A sua Cruz, a radicalidade do seu amor é a chave que abre esta porta. O amor d'Aquele que, sendo Deus, se fez homem para poder morrer - este amor tem a força para abrir esta porta. Este amor é mais forte que a morte. Os ícones pascais da Igreja oriental mostram como Cristo entra no mundo dos mortos. A sua veste é luz, porque Deus é luz. 'A noite é clara como o dia, as trevas são como a luz' (cf. Sl 139 [138], 12). Jesus que entra no mundo dos mortos leva os estigmas: as suas feridas, os seus padecimentos tornaram-se poder, são amor que vence a morte. Ele encontra Adão e todos os homens que esperam na noite da morte. À sua vista parece até ouvir a oração de Jonas: 'Clamei a vós do meio da morada dos mortos, e ouvistes a minha voz' (Jn 2, 3). O Filho de Deus na encarnação fez-se uma só coisa com o ser humano - com Adão. Mas só naquele momento, em que cumpre o extremo ato de amor descendo na noite da morte, Ele cumpre o caminho da encarnação. Com a sua morte Ele leva Adão pela mão, leva todos os homens em expectativa para a luz ${ }^{531}$.

Após falar da impossibilidade do ser humano alcançar a salvação, a qual é oferecida por Cristo, o Papa concluiu sua homilia com uma prece ao Ressuscitado:

Senhor, mostra hoje também que o amor é mais forte do que o ódio. Que é mais forte do que a morte. Desce também nas noites e na mansão dos mortos deste nosso tempo moderno e segura pela mão aqueles que esperam. Leva-os para a luz! Permanece também comigo nas minhas noites escuras e leva-me para fora! Ajuda-me, ajuda-nos a descer contigo na escuridão daqueles que estão à espera, que das profundezas gritam por ti! Ajuda-nos a levar-lhes a tua luz! Ajuda-nos a chegar ao 'sim' do amor, que nos faz descer e por isso mesmo elevarmo-nos juntamente contigo! Amém ${ }^{532}$.

Em uma meditação proferida em Turim (02 de maio de 2010), diante do

Santo Sudário, o Papa retomou o tema:

\footnotetext{
${ }^{531} \mathrm{http} / / / \mathrm{www} . v a t i c a n . v a / h o l y \_f a t h e r /$ benedict_xvi/homilies/2007/documents/hf_benxvi_hom_20070407_veglia-pasquale_po.html 532 Ibid
} 
Naquele 'tempo-além-do-tempo' Jesus Cristo 'desceu à mansão dos mortos'. O que significa esta expressão? Quer dizer que Deus, feito homem, chegou até ao ponto de entrar na solidão extrema e absoluta do homem, onde não chega raio de amor algum, onde reina o abandono total sem palavra de conforto alguma: 'mansão dos mortos'. Jesus Cristo, permanecendo na morte, ultrapassou a porta desta solidão última para nos guiar também a nós a ultrapassá-la com Ele. Todos nós sentimos algumas vezes uma sensação assustadora de abandono, e o que mais nos assusta é precisamente isto, como quando somos crianças, temos medo de estar sozinhos no escuro e só a presença de uma pessoa que nos ama pode dar-nos segurança. Aconteceu exatamente isto no Sábado Santo: no reino da morte ressoou a voz de Deus. Sucedeu o impensável: ou seja, que o Amor penetrou 'na mansão dos mortos': também no escuro extremo da solidão humana mais absoluta nós podemos escutar uma voz que nos chama e encontrar alguém que nos pega pela mão e nos conduz para fora. O ser humano vive porque é amado e pode amar; e se até no espaço da morte penetrou o amor, então também lá chegou a vida. Na hora da extrema solidão nunca estaremos sozinhos: 'Passio Christi. Passio hominis'. Este é o mistério do Sábado Santo! Exatamente do escuro da morte do Filho de Deus brilhou a luz de uma esperança nova: a luz da Ressurreição ${ }^{533}$.

Menções menores foram também feitas pelo Papa no Discurso à Cúria Romana no Natal de 2009 (recordando sua visita à Terra Santa) ${ }^{534}$, na Mensagem

Pascal Urbi et Orbi de $2009^{535}$ e na Homilia da Vigília Pascal de $2010^{536}$.

\footnotetext{
$533 \mathrm{http} / / /$ www.vatican.va/holy_father/benedict_xvi/speeches/2010/may/documents/hf_benxvi_spe_20100502_meditazione-torino_po.html acesso em 01/12/2010 22:52.

${ }^{534}$ Vimos na Jordânia o ponto mais baixo da terra junto do rio Jordão. Como poderíamos deixar de nos sentir interpelados pela palavra da Carta aos Efésios, segundo a qual Cristo 'desceu às regiões inferiores da terra' (Ef 4, 9)? Em Cristo, Deus desceu até à última profundidade do ser humano, até à noite do ódio e da cegueira, até à escuridão do afastamento do homem de Deus, para aí acender a luz do seu amor. Ele está presente até na noite mais profunda: 'Se descer aos infernos, lá Vos encontro' esta afirmação do Salmo 139/138, 8 realizou-se na descida de Jesus. (http://www.vatican.va/holy_father/benedict_xvi/speeches/2009/december/documents/hf_benxvi_spe_20091221_curia-auguri_po.html). Acessado em: 23 de Novembro de 2010.

${ }^{535}$ Até o próprio reino da morte foi libertado, porque também aos «infernos» chegou o Verbo da vida, impelido pelo sopro do Espírito (Sal 139/138,8)

http://www.vatican.va/holy_father/benedict_xvi/messages/urbi/documents/hf_benxvi_mes_20090412_urbi-easter_po.html. Acessado em: 23 de Novembro de 2010.

${ }^{536}$ Citando um acréscimo ao apócrifo judaico "Vida de Adão e Eva", no qual o arcanjo Miguel diz a Set, filho de Adão: O óleo da misericórdia para toda a eternidade será dado a quantos deverão renascer da água e do Espírito Santo. Então, o Filho de Deus rico de amor, Cristo, descerá às profundezas da terra e conduzirá o teu pai ao Paraíso, para junto da árvore da misericórdia. (http://www.vatican.va/holy_father/benedict_xvi/homilies/2010/documents/hf_benxvi_hom_20100403_veglia-pasquale_po.html). Acessado em: 23 de Novembro de 2010.
} 


\subsection{3 - Karl Rahner}

Karl Rahner entende a descida de Cristo aos infernos dentro do contexto de sua peculiar compreensão da morte humana; o descensus é "um momento da morte de Cristo", enquanto intrínseco à própria natureza da morte humana que ele padeceu $^{537}$.

Para Rahner, porém, a tradicional compreensão da morte como separação entre alma e corpo não é suficiente. Entende a morte como um evento singular que, diz respeito à totalidade do homem, e não somente ao seu corpo, não acontecendo na morte uma separação absoluta entre a espiritualidade humana e a materialidade do mundo ${ }^{538}$. Pelo contrário, na morte a alma passa a relacionar-se de modo ainda mais amplo com a materialidade do mundo, tornando-se não " $a$ cósmica, mas cósmica-universal" "539, fazendo com que o homem se torne um "verdadeiro ser cósmico" "540.

Aplicando à morte de Cristo "esta hipótese de antropologia metafísica da morte ${ }^{, 541}$, Rahner conclui que a descida do Filho de Deus ao Hades constitui o cumprimento de sua encarnação, depois que sua realidade humana espiritual

\footnotetext{
537 Abbiamo già detto precedentemente che, secondo la documentazione del Nuovo Testamento, questa discesa di Cristo agli inferi non viene interpretata semplicimente come un'opera soteriologica a favore degli uomini giusti del tempo avanti Cristo che non avevano potuto essere partecipi della visione di Dio prima della morte di Cristo, ma viene invece interpretata come un momento della stessa morte, in quanto Egli è morto de morte umana. Karl Rahner, Sulla teologia della morte, 60.

538 /.../ nella morte l'anima dell'uomo entra completamente nella condizione al di là del mondo, oppure viene a trovarsi proprio per questo in una maggiore vicinanza e in più intimo rapporto a quel fondamento difficilmente intelligibile, ma tuttavia reale, dell'unità del mondo, nel quale tutte le cose del mondo sono collegate e comunicano fra loro prima ancora del loro reciproco influsso, no essendo più vincolata dalla sua forma corporea particolare?. (p. 20). Após diversas considerações, Rahner inclina-se pela segunda hipótese.

${ }^{539}$ Ibid. p. 22.

${ }^{540}$ Un tale rapporto al mondo, senza che venga maggiorato fino a essere un rapporto come quello tra anima e rispettivo corpo, potrebbe anche significare che l'anima, la quale, abandonando nella morte la sua forma fisica limitata, si apre all'universo, contribuisce in certo qual modo a determinare la totalità del mondo quale fondamento della vita personale degli esseri in quanto fisico-spirituali. Non solo per il fatto - e ciò fa parte veramente dei dati della dottrina di fede - che per Dio la qualità morale del singolo uomo (compiuto) conferisce a determinare il suo comportamento verso il mondo e tutti gli altri singoli, ma nel senso pure che nel cosmo subentra una ripercussione diretta e in esso immanente, proveniente da ogni singola persona, che nella morte diviene cosmico-universale, attraverso il suo rapporto ontologico-reale, che si apre al mondo come totalità. (Ibid, p. 23).

${ }^{541}$ Ibid. p. 59.
} 
adquiriu, precisamente através da morte, "uma relação ontológico-real com a totalidade do mundo"542 não apenas trazendo a salvação para todos os homens, mas tornando-se "também em sua humanidade o que Ele, pela sua dignidade sempre foi, isto é, o coração do mundo, o centro mais íntimo de toda realidade criada" ${ }^{543}$.

\subsection{4 - Hans Küng.}

Hans Küng em sua obra "Vida eterna" refere-se a diversas dificuldades que o artigo do Símbolo Apostólico da descida de Cristo aos infernos apresenta ao homem moderno. $\mathrm{O}$ autor primeiramente se pergunta sobre o significado da afirmação, se esta não seria o equivalente ao "topos histórico-religioso que já podemos constatar entre os primitivos e que também aparece nas religiões desenvolvidas /.../ o mito do deus, ou também do homem - em sonho, visão ou morte aparente - ao qual se permite penetrar no obscuro e misterioso mundo inferior, no sombrio reino dos mortos"544, e do qual ele apresenta diversos exemplos.

Mostra, a seguir, que a própria compreensão do termo "inferno" no referido artigo de fé variou ao longo dos séculos, passando de "reino dos mortos" (de todos os mortos) para, em oposição ao paraíso, reino dos bem-aventurados, reino dos não bem-aventurados ${ }^{545}$. "Que concepção subjaz a este descensus ad inferos?"546

Admitida a primeira compreensão o artigo, estaria simplesmente reafirmando a morte de Cristo já professada no Símbolo; por que, então, seria necessário um artigo de fé referente a sua descida ao reino dos mortos? Admitida a segunda compreensão, que supõe uma ação de Cristo entre a morte e a

\footnotetext{
${ }^{542}$ Ibid. p. 59.

${ }^{543}$ Ibid. p. 70-72.

${ }^{544}$ KÜNG, H.; ¿ ¿Vida eterna?, 1983.pp. 208-209

${ }^{545}$ Ibid p. 209.

${ }^{546}$ Ibid.
} 
ressurreição, deve-se perguntar se tal afirmação encontra fundamento suficiente no Novo Testamento ${ }^{547}$.

Após apresentar as diferentes interpretações clássicas da conhecida passagem de 1Pd 3,18-19548, Hans Küng rejeita, baseando-se na exegese atual, que ela se refira à descida de Cristo aos infernos, ou a uma atividade sua entre a morte e ressurreição. Segundo ele, o texto da Primeira Pedro, trata antes, "do Cristo, ressuscitado e transfigurado pelo Espírito que, como novo Henoc, anuncia sua ascensão (e não em sua descida aos infernos!) aos anjos caídos nas regiões inferiores do céu (não no interior da terra!) sua condenação" ${ }^{\text {,49. }}$.

Pergunta, então, Hans Küng, “que pensar deste artigo de fé”? ${ }^{550}$ Pergunta à qual ele não oferece uma resposta, propriamente falando, mas "algumas orientações":

1. Tanto para o pensamento bíblico como para a Igreja primitiva e medieval, a morte e sepultura é o mesmo que descer ao mundo dos mortos (sheol ouo hades), pelo que não se tem uma interpretação particular do referido artigo.

2. A interpretação da descida de Jesus, aos infernos como abandono ou ira da parte de Deus (segundo ele mais fundamentada bíblicamente), também não exige um artigo junto à afirmação da morte e sepultura.

3. Os textos do Novo testamento não apresentam de modo algum uma descida aos infernos, nem uma ação ou sofrimento de Jesus entre a morte e a ressurreição.

4. A solidariedade para com os mortos e a salvação da humanidade précristã ou extra-cristã pode ser legitimada teologicamente, sem recorrer

\footnotetext{
${ }^{547}$ ¿De verdad no se ha querido siempre significar con ello un suceso específico entre la muerte $y$ la resurrección\} ¿Por tanto, un descenso a los infiernos, sea cual fuere la forma de entenderlo? Si se opta por esta segunda variante, la cuestión se plantea en estos términos: ¿Se puede, a la vista del Nuevo Testamento, justificar semejante acción (o pasión) más allá de la muerte? P. 210

$5481^{\text {a }}$ ) pregação de Jesus no reino dos mortos, oferecendo a eles uma possibilidade de conversão (Clemente de Alexandria); $2^{\mathrm{a}}$ ) Cristo preexistente que pregou, antes da encarnação, aos pecadores pela boca de Noé (Santo Agostinho); $3^{\mathrm{a}}$ ) a morte de Cristo como experiência da ira de Deus, abandono (Lutero e Calvino); $4^{\mathrm{a}}$ ) a alma (espírito) de Cristo que anunciou o evangelho aos justos da Antiga Aliança (Contrarreforma) (cf. oc. p. 211).

${ }^{549}$ KUNG, H., Op.cit. 212.

${ }^{550}$ KUNG, H., Op.cit. 213.
} 
a representação mitológica de uma pregação, ou marcha triunfante, ou dolorosa de Cristo nos infernos.

5. "De tudo isso se deduz claramente a relatividade histórica deste artigo de fé sobre o 'descensus"”, que apareceu "em meados do século IV em uma profissão de fé oriental" 551 .

À questão: "Não deveria este artigo do descensus ser eliminado do Credo?", o autor responde recordando a doutrina da hierarquia das verdades, e afirmando a importância tradicional e ecumênica do Símbolo apostólico, que mesmo “com toda sua problematicidade, não deve ser substituído”, devendo, porém, ser interpretado criticamente para o nosso tempo; particularmente as afirmações da descida aos infernos e ascensão estão condicionadas por antigas interpretações do mundo ${ }^{552}$.

O estudo sobre a descida de Cristo aos infernos introduz para Hans Küng outro ainda mais complexo: "Acaso se pode hoje continuar a crer no inferno? "553, tema que ultrapassa os objetivos de nossa exposição.

\footnotetext{
${ }^{551}$ Op.cit. 215. Hans Küng se equivoca ao afirmar em relação à quarta fórmula de Sírmio "lo que en principio era pura descripción del destino mortal de Jesús, se interpretó muy pronto en el Occidente com o primer acto de la victoria de Jesús sobre el demonio" (oc. 215). Como vimos, a quarta fórmula de Sírmio menciona, junto à afirmação de que Jesus "desceu às regiões subterrâneas" que Ele "realizou a economia com os que ali estavam; que vendo-o os guardiões do Hades tremeram (Jó 38,17b)", uma clara menção à eficácia soteriológica do Descensus.

${ }^{552}$ KUNG, H., Op.cit. p. 216

${ }^{553} \mathrm{Id}$.
} 


\section{7 - Teólogos de língua francesa}

A corrente francesa tem como característica apresentar uma abordagem cristológica e soteriológica da descida de Cristo à mansão dos mortos. Longe de pensar em uma referencia com a cruz e a morte de Cristo, o artigo de fé passa a estar mais associado à glorificação de Cristo. Com efeito, surge a necessidade em dar um novo sentido à descida de Cristo para a fé cristã. Tanto a vitória sobre o mal, quanto a solidariedade aos que morreram, se tornaram temáticas para o desenvolvimento teológico da descida de Cristo à mansão dos mortos, para a corrente francesa.

\subsection{1 - Jean Galot.}

Encontramos o pensamento do teólogo francês Jean Galot em um artigo da Nouvelle Revue Théologique, La Descente du Christ aux enfers ${ }^{554}$, e no $13^{\circ}$ capítulo ("A glorificação espiritual de Cristo na morte”) de sua Cristologia 555 . Em ambos os textos o autor, fundamentando-se na passagem de 1Pd 3,18ss, abordando a descida de Cristo aos infernos nos dois aspectos, cristológico (qual a condição de Cristo após a morte?) e soteriológico (qual a ação de Cristo após a morte?):

O problema da descida aos infernos é primeiramente um problema cristológico, porque nos obriga afirmar qual era a situação pessoal de Cristo na morte, e o que significa a estadia de Cristo no lugar onde se encontravam os defuntos (...). Por outro lado, convém elucidar a missão realizada por Cristo nos infernos; é o problema soteriológico ${ }^{556}$.

No que se refere à cristologia, o autor associa fundamentalmente a descida de Cristo aos infernos à sua glorificação; o descensus, assim, não faz parte da cruz e da morte, mas da ressurreição de Jesus. Isso porque ele entende a afirmação da 1Pd 3,18, "morto na carne e vivificado no espírito" referindo-se ao estado de

${ }^{554}$ GALOT, J.; La Descente du Christ aux enfers, in: Nouvelle Revue Théologique, Tome 83 (1961) 471-491.

${ }^{555}$ GALOT, J.; Gesù liberatore. Cristologia II Firenze: Libreria Editrice Fiorentina, 1983,.p. 327355.

556 GALOT, J.; La Descente du Christ aux enfers, in: Nouvelle Revue Théologique, Tome 83 (1961) p. 472. 
Cristo durante o triduum mortis. Longe de compreender as duas condições de Cristo "morto" e "vivificado" como estados separados um do outro, Galot salienta que ambos dizem respeito a um único momento ${ }^{557}$ : no momento da morte a alma de Cristo passa a estar numa ordem superior e gloriosa, recebe uma "vivificação" e glória que antecedem a Ressurreição.

É preciso salientar a afirmação essencial: depois de sua morte, Cristo recebeu uma vida nova espiritual. Ele foi glorificado em sua alma antes de estar, três dias, em seu corpo. 'Depois da morte, a alma de Cristo, diz Chaine em seu comentário, está plenamente gloriosa e triunfante, ela foi vivificada'. Nós estamos habituados tanto a falar da morte e da ressurreição de Jesus quanto poderíamos estar inclinados a identificar Ressurreição e Glorificação de Cristo. Ora a primeira glorificação aconteceu antes da Ressurreição. O primeiro fruto do sacrifício redentor, ou seu primeiro coroamento, foi esta plenitude da vida divina que apreendeu a alma de Jesus no momento onde a morte veio fazer sua obra ${ }^{558}$

No que se refere à soteriologia, apoiando no texto: "pregou aos espíritos encarcerados", Jean Galot vê o descensus como a salvação concedida aos mortos da antiga Aliança. Evitando as questões da possibilidade de conversão após à morte (aos que morreram em pecado), Galot afirma que na Primeira Pedro

o autor quer mostrar no texto o que se encontra no 'antítipo' ou realidade correspondente do Novo Testamento. Há uma pregação de Cristo para os incrédulos de outrora, uma possibilidade para eles de conversão e de acesso a Deus. Porém, de modo indeterminado, sem pretender, por exemplo, que historicamente toda a geração do dilúvio caiu num estado de culpabilidade, exceto oito pessoas que teriam sido salvas. Não é a realidade histórica desta geração que interessa, mas o que esta representa para o batismo. Não há pretensão em afirmar que houve pessoas mortas em estado de pecado aos quais Cristo ofereceu uma possibilidade de conversão no momento da descida aos infernos. Quer unicamente indicar que às gerações anteriores foram oferecidas por Cristo o acesso a Deus, e que para elas, também foi pregar a possibilidade de conversão. A salvação concedida aos antigos é a imagem da salvação concedida atualmente mediante o batismo ${ }^{559}$.

Por fim, bastante original, é a relação que o autor estabelece entre a descida de Jesus aos infernos com a Páscoa hebraica (libertação ao povo da antiga

\footnotetext{
${ }^{557}$ Mis à mort dans la chair' et 'rendu vivant dans l'esprit' paraissent se rapport tous deux à la même situation du Christ, celle où il s'est trouvé par le fait de as mort. Aucun intervalle n'est indique entre cette mise à mort et celle vivification; plutôt que d'avoir lieu à divers moments, elles sont présentées sur des plants différents, celui de la chair et celui de l'esprit, comme deux aspects d'un même état. Ibid. 473-474.

${ }^{558}$ Ibid., 479

${ }^{559}$ Ibid., 484
} 
Aliança) e Ressurreição com a Páscoa cristã (libertação para o povo da nova Aliança $)^{560}$.

\subsubsection{Christian Duquoc.}

O teólogo francês Christian Duquoc apresenta-nos sua posição referente à descida de Cristo aos infernos em um artigo de Lumiere et vie ${ }^{561}$, retomada no segundo volume de sua Cristologia, Ensaio dogmático ${ }^{562}$.

A primeira consideração feita por Duquoc sobre este artigo do Símbolo é o seu sentido como um acontecimento salvífico ${ }^{563}$. Duquoc fala da dificuldade para compreensão que o tema traz ao homem moderno, o que não deve ser motivo de levar à desistência de abordá-lo ${ }^{564}$. Segundo ele, essa abordagem pode ser feita através de uma análise cultural ${ }^{565}$.

\footnotetext{
560 Per terminare, osserviamo Che si può esprimere il senso della discesa agli inferi nel quadro liturgico come un passaggio dalla Pasqua ebraica alla festa cristiana di Pasqua. Il Cristo è morto nel momento in cui stava per cominciare la Pasqua ebraica, Pasqua che coincideva con il sabato. La Pasqua era la festa della liberazione del popolo, ricordo della grande liberazione del passato, e promessa di salvezza futura; il sabato era il simbolo del riposo finale, quello dell'era messianica. In questo momento della Pasqua e del sabato, il Cristo ha procurato la liberazione e il riposo messianico a tutte le anime dell'antica economia. Egli ha così compiuto per tutte loro le promesse della Pasqua e del sabato. Una volta terminati questa Pasqua e questo sabato, il Cristo ha stabilito, tramite la sua rissurrezione corporea, una nuova Pasqua e un nuovo sabato per quelli che vivono sulla terra: festa di Pasqua, domenica, simbolo della nuova era, della liberazione già compiuta $\mathrm{e}$ del riposo messianico, già assicurato. (GALOT, J.; Gesù liberatore. Cristologia II, p. 354-355).

${ }^{561}$ DUQUOC, C., La descente du Christ aux enfers, problématique théologique, Lumiere et vie 87 (1968) 45-62.

562 DUQUOC, C., Cristologia Ensaio Dogmático II. O Messias, pp. 46-62.

${ }^{563}$ Toda afirmação de fé se reveste, pois, de valor prático. Confessar que Jesus desceu aos infernos não é descrever a odisseia de sua alma, como curiosidade sobre o além, nem mesmo significa especular sobre a condição das almas "mortas", mas é relatar um evento salvífico, isto é, que ilumina, hoje também, a situação do homem diante de Deus, desviando-o da perdição. DUQUOC, C., La descente du Christ aux enfers, problématique théologique, Lumiere et vie 87 (1968), p. 47.

${ }^{564}$ Apparement, la descente aux enfers a perdu pour nous sa valeur symbolique et pratique. Elle relève davantage du folklore que du sérieux de la foi. On ne doit pourtant pas prendre trop rapidement son parti de ce que des représentations insérées dans le Credo deviennent religieusement indifférentes. Les proclamer et les accepter sans requérir qu'elles aient un sens pour nous, c'est faire accroire tôt ou tard que les données dogmatiques sont des superstructures, vénérables en raison de leur antiquité, mais vides. Idem.

${ }^{565}$ DUQUOC, C., Cristologia Ensaio Dogmático II. O Messias, p. 47.
} 
Segundo Duquoc, o artigo da descida de Cristo à morada dos mortos, de inserção tardia no Símbolo, pretendia originalmente apenas significar a realidade da morte de Jesus ${ }^{566}$. Esta era também a postura do Novo Testamento, que realizou, frente às representações judaicas do além, um processo de “demitização".

Se essa interpretação for correta, o Novo Testamento, parece, não teve nenhum interesse na odisséia infernal de Jesus. Comparando a abundância de imagens e representações do judaísmo e mais tarde, dos Padres, na descrição das realidades extra-terrestres, com a diferença de interesses: o judaísmo e os Padres crêem ingenuamente num mundo do Além, cuja topografia pode, a rigor, ser traçada, e o Novo Testamento, ao contrário, põe toda sua atenção no sentido antropológico e, consequentemente, crístico, das representações originariamente cosmológicas. Para o Novo Testamento essas mesmas representações são símbolos da situação humana de proximidade ou de afastamento de Deus. Fazendo isso, "demitiza", sem, no entanto, abandonar uma linguagem falando mais à imaginação que à razão. 'Hoje mesmo estarás comigo no paraíso': não é o lugar que conta, é a vida na presença de Cristo, a vida com Deus. Ninguém pode saber qual seja a forma de que se reveste para o homem, essa proximidade com Deus, ela não é descritível, uma vez que ninguém jamais viu a Deus. A morte é real, ela destrói a dimensão histórica e geográfica que serve de substrato à nossa linguagem, e o Novo Testamento, utilizando de representações judaicas, deixa na verdade, de falar do Além em termos do aquém. Não recusa ele um discurso sobre o Além, mas exige que esse mesmo discurso incida sobre o sentido humano e atual do além. Somente a linguagem antropológica é adaptada para esse novo estilo, e a linguagem cosmológica relacionada as realidades últimas, no judaísmo e nos padres, se torna inútil ${ }^{567}$.

Ora, segundo nosso autor, não foi esse o sentido dado ao descensus pela Antiguidade cristã. Antes, os Padres, com as diversas imagens de conquista, libertação e pregação, pretendiam acentuar "que Jesus já é vitorioso quando se apresenta na morada dos mortos" 568 . Tais imagens significaram um processo de “'remitização', processo que corre o risco de abafar com a capa do anedótico e do maravilhoso, o autêntico sentido da descida aos Infernos" (p. 52).

566 Duquoc não especifica a qual "Confissão de Fé do final do séc. IV" (cf. p. 48) ele se refere. Notar, porém, que a IV fórmula de Sírmio, como vimos, com a menção da economia e do tremor dos porteiros infernais já dava um claro sentido soteriológico à descida aos infernos. Quanto ao Símbolo de Aquiléia (ao qual é mais provável que o autor se refira), já nas explicações de Rufino percebe-se também claro sentido soteriológico.

${ }^{567}$ DUQUOC, C., Cristologia Ensaio Dogmático II. O Messias, p. 53.

${ }^{568}$ Ibid. 49 
Duquoc, sem negar o valor da linguagem mitológica ou simbólica para exprimir as realidades desta ordem $^{569}$, e admitindo a inevitabilidade de seu uso pela Igreja antiga ${ }^{570}$, afirma a necessidade de uma nova demitização:

O que foi para os cristãos de outrora uma ajuda na fé, é de agora em diante obstáculo, pois ninguém toma a sérios as representações subjacentes à afirmação da descida aos infernos. 'Demitizar' é retornar ao Novo Testamento, devolver às imagens sem sentido para nós seu valor originário, e devolver à formulação dogmática seu valor prático ${ }^{571}$.

Segundo ele, esta demitização não é uma pretensão moderna, já tendo sido realizada por Calvino em sua Instituição Cristã, ao qual, porém, ele não deixa de criticar $^{572}$. O conteúdo do artigo de fé é expresso por Duquoc sob a ideia da solidariedade de Jesus. A descida aos Infernos

evoca o irremediável da morte, deixando entrever, porém, a esperança de que ela seja vencida. /.../ Descer aos Infernos para Jesus é defrontar-se com o irremediável e, então, assumir de corpo inteiro, o destino trágico do homem, é acompanhá-lo até onde ele se sente mais abandonado ${ }^{573}$.

A ideia de Inferno, além de expressar a tragicidade da condição, situa-a em relação a Deus e ao seu silêncio:

Jesus enfrenta esse silêncio. Descer aos Infernos é enfrentar a ausência de Deus, cujo sinal é a morte. 'Não são os mortos que te louvam', diz o Salmista. Jesus, mais do que ninguém, conhece esse abandono, mas Jesus, ao morrer, entrega-se inteiramente a Deus. Ele contra toda esperança, vence os Infernos como ausência de Deus. O que nos concede é permanecer neste silêncio sem perder a esperança ${ }^{574}$.

\footnotetext{
$569 \mathrm{O}$ fato de se dar um sentido antropológico às realidades do Além não nos obriga a assumir com relação a este uma linguagem racional no sentido científico do termo. Nenhuma linguagem direta pode apreender essa possibilidade. Ela está sempre presente e sempre velada, em nossa experiência. Um contorno é necessário, essa possibilidade só pode ser evocada. Ibid. p. 54.

${ }^{570}$ Era preciso expressar a exterioridade da morte, seu poder, o fato de o homem não ser senhor da própria vida, era preciso mostrar o Cristo enfrentando esse poder e destruí-lo. Vivendo num mundo de representações cosmológicas,, não se pode entender como os crentes tivessem podido expressar o irremediável da morte e da vitória de Cristo, dramatizar esse combate, sem exteriorizálo. Ibid. p. 56

${ }^{571}$ Ibid. p. 56.

572 A linguagem de Calvino, embora não seja cosmológica, nem por isso mesmo deixa de ser 'mítica': descreve o Além em termos do aquém. Substitui o cosmos pela estrutura jurídica da sociedade e pelas representações aliadas a uma ordem ideal em que a 'reparação' e a 'satisfação' se tornam necessárias, uma vez que houve uma violação. Ibid. p. 57.

${ }^{573}$ Ibid. p. 58.

${ }^{574}$ Ibid. pp. 59-60.
} 
O autor conclui pela importância que deve ter a afirmação da descida de

Cristo aos infernos, também para ao cristão do mundo moderno:

O Cristianismo poderia confessar simplesmente a vida ressuscitada de Jesus Cristo. Faltaria, porém, a essa confissão, a expressão de nossa condição. A vida ressuscitada de Cristo é nossa, no sentido de que ela é a prova de que esse homem venceu o destino. Não existe, pois, Inferno que não seja criação do homem, não existe, então, inferno que seja irremediável, a não ser aquele que o homem cria como irremediável. É nossa própria história que é simbolizada pela descida aos Infernos. É por isso que ela é uma fórmula dogmática descritiva de um evento que nos diz respeito. Ela proclama que aquilo que o homem Jesus enfrentou, nós, também o enfrentaremos em sua vitória, e, então, na esperança. $O$ fato de Jesus ter descido aos Infernos para de lá subir vivo, marca o espaço livre concedido à ação do homem. Nenhuma potência pesa sobre sua liberdade, a não ser o seu próprio instinto do nada. A confissão de fé narra, com efeito, a descida aos Infernos à luz da Ressurreição. A vitória é conquistada desde o momento em que esse confronto com a potência da morte é proclamado. É pelo fato de que o irremediável não é exterior à decisão do homem, que esse mesmo irremediável pode ser vencido. O destino é forjado pelo próprio homem. Toda a luta contra o destino é, então, uma subida aos Infernos. Em Jesus, a humanidade inteira é assumida nesse movimento de libertação. O Cristo não substitui o homem na rejeição do destino. Ele suscita, abre, dá o primeiro passo no combate. Quando o último inimigo estiver vencido - a morte - Jesus entregará o 'Reino' ao Pai. Mas, por ora, a humanidade não deixa de descer aos Infernos, e pela graça de Cristo, de lá subir. A esperança cristã, do que Péguy nos diz que causa admiração ao próprio Deus, é conseqüência prática da afirmação de nosso CREDO: o Cristo desceu aos Infernos $^{575}$.

\subsection{3 - Louis Lochet.}

A obra de Louis Lochet Jésus descendu aux enfers ${ }^{576}$ é, na verdade, um estudo de soteriologia, que trata principalmente da questão da eternidade (interminabilidade) do inferno. É nessa perspectiva que ele trata o tema da descida de Jesus aos infernos: "Parece-nos, com efeito, que a descida aos infernos, afirmada pela Igreja no Credo e revelada pela Escritura, não é somente uma espécie de episódio estranho e um tanto mítico da missão de Jesus: passagem sem conseqüências para nossa vida presente e para nossa esperança cristã’577. Afirma

\footnotetext{
${ }^{775}$ DUQUOC, C.; Cristologia, Ensaio Dogmático II: O Messias. 1996, p. 60.

576 Paris, Editions du Cerf, 1979. O título dado à tradução espanhola realça mais o sentido soteriológico: Louis Lochet, La salvación llega a los infiernos, Sal Terrae, Santander, 1980 (tradução de Juan J. Gracía Valenceja)

${ }^{577}$ LOCHET, L.Jésus descendu aux enfers, p. 15.
} 
que a descida de Cristo aos infernos deve ser vista como "uma dimensão da missão de Cristo e um aspecto sempre atual do mistério da salvação"578.

Em sua obra após apresentar os textos da Escritura referentes à condenação eterna, especialmente as passagens do Evangelho ${ }^{579}$, e concluir "que a salvação de todos é impossível, visto que há condenados"580, Lochet passa a mostrar, baseado na mesma Sagrada Escritura, que “Deus é o Senhor do impossível': esta não é uma afirmação ocasional que se poderia encontrar em um ou outro texto do antigo ou do Novo Testamento. É toda a Bíblia, desde o Gênesis até o Apocalipse, que revela esta certeza. Essa é, através de mil situações paradoxais, a mensagem central: um eixo ao qual convergem todos os caminhos" ${ }^{\prime 581}$.

Essa salvação "impossível” nos é concedida pela Cruz, pela solidariedade de Cristo com os pecadores. Neste contexto o autor insere a reflexão sobre a descida de Cristo aos infernos:

Descer aos infernos quer dizer /.../ que Jesus, por amor se fez solidário de todos os sofrimentos humanos, que procedem dos pecados, de todos os sofrimentos dos pecadores, não somente os sofrimentos da terra, mas os que penetram nas trevas dos infernos; não só dos vivos, mas também dos mortos; não só os de seu tempo, mas os de todos os tempos; não só dos justos, mas os dos réprobos. Em sua solidariedade com o homem foi até o final, até a solidariedade com os pecadores; em sua solidariedade com os pecadores foi até o final, chegando ao fundo do abismo; em sua solidariedade com a criação foi até o final, solidarizando-se com todos e com tudo, desde o mais alto do céu até o mais profundo dos infernos. Que mistério! $!^{582}$

Seguindo de modo bem próximo o pensamento de Von Balthasar, Lochet termina por concluir na possibilidade de salvação mesmo nos infernos:

\footnotetext{
${ }^{578}$ Ibid. p. 16-17.

${ }^{579}$ Cela est vrai pour tous. Pour tous leur amour ou leur refus d'amour entraînera le bonheur ou le malheur éternel, le cielo u l'enfer. Et celui-là même qui les jugera à la fin des temps será celui qu'ils auront accueilli ou rejeté en l'autre, même sans le connaître encoré: le Christ. Ibid. p. 35.

${ }^{580}$ Ibid. p. 47.

${ }^{581}$ Ibid.

${ }^{582}$ Ibid. p. 91.
} 
Creio no inferno porque esta dimensão do mistério do homem e do mistério de Deus aparece clara e fortemente afirmada pela Palavra de Deus, ainda que não com esse mesmo termo. /.../ mas, precisamente por ser um mistério cristão, nossa fé no inferno não pode separar-se de nossa fé na totalidade do mistério de Cristo. Não é outro mistério, é o mesmo. Como o mistério de Cristo é mistério de salvação, nossa fé no inferno é uma dimensão de nossa fé no mistério da salvação. Eu creio em Jesus Salvador de todos, desde o mais alto dos céus até o mais profundo dos infernos ${ }^{583}$.

\subsection{4 - Adolph Gesché}

O tema da descida de Cristo aos infernos foi tratado pelo teólogo belga Adolphe Gesché em um artigo publicado na Revue Théologique de Louvain ${ }^{584}$, o qual foi depois retomado (e ligeiramente ampliado) no sexto volume da série “Deus para pensar: O Cristo"

Gesché começa a tratar de nosso tema, quando analisa os relatos do túmulo vazio e percebe sua relatividade (devido a diversidade de significados que o fato poderia ter).

Não se deve espantar ao verificar que essa narrativa do túmulo tenha, enfim, apenas uma importância relativa na tradição. São Paulo parece ignorá-la completamente, uma vez que não fala dela. Ou, se conhecia esse episódio, não julga indispensável falar dele. A igreja jamais considerou estar obrigada a fazer menção deles em seus Credos. O famoso e longo discurso de Pedro que, no Pentecostes, funda a fé cristã na Ressurreição (At 2,14-16) fala dele somente muito indiretamente e de maneira que parece mais ter como alvo a saída dos Infernos do que a do túmulo. Por sua vez, os ícones orientais representam Cristo saindo do Inferno, jamais "saindo do túmulo" (o que aliás, o Evangelho tampouco faz $)^{586}$.

O autor sabe das dificuldades que sua opção metodológica impõe: "Escolhendo falar da Ressurreição de Jesus pelo viés do tema da Descida ao

${ }^{583}$ Ibid, p. 125.128-129; No que se refere a ausência de liberdade dos condenados ao inferno afirma: La liberté du damné est incapable de se retourner d'elle-même vers Dieu, c'est pourquoi em lui-même est sans issue. Mais La liberte de Dieu qui est presente em enfer est-elle capable d'y agir comme Sauveur?Dieu, qui créel'être, peut-il recrée au-dedans de l'être, par CE lien qui Le relie à as créature une liberte nouvelle?. Ibid, p. 133).

584 Adolphe Gesché, L'agonie de La Réssurrection ou La Descente aux Enfers, RTL 25 (1994) 529.

${ }^{585}$ Adolphe Gesché, $O$ Cristo, Paulinas, São Paulo, 2004 (tradução de Carlos Felício da Silveira). A obra foi publicada originalmente pelas Edicions du Cerf, em 2001 (Dieu pour penser, VI, Le

Christ).

${ }^{586}$ Ibid. p. 132. 
Inferno, escolhe-se antes de tudo o mais difícil e problemático: o de todos os riscos da ingenuidade cosmológica e de todos os perigos da deriva mitológica" ${ }^{\text {587 }}$, mas justifica sua opção afirmando que "a linguagem cosmológica e o discurso mitológico têm capacidades que não tem a razão puramente racional”"588.

Por experiência teológica sabe-se, aliás, que quanto mais um dado de fé (pensemos na doutrina do pecado original) aparece oculto em um invólucro mitológico, mais temos nisso o sinal de que se trata realmente de um assunto importante mas difícil, e que, justamente por isso, precisou, como que inconscientemente, apelar para recursos outros que aos das abstrações comuns. Do mito, não se deve apagar a chama ${ }^{589}$.

As fontes por ele apresentadas são as tradicionais: "praticamente todos os Credos antigos, todas as liturgias batismais e eucarísticas (tanto orientais como ocidentais), todos os discursos petrinos e paulinos mencionam a Descida ao Inferno como parte integrante da gesta pascal" ${ }^{150}$.

Analisando o discurso de Pedro em At 2,19-35, Gesché faz a importante observação que, conforme a seqüência de "lugares" apresentados no texto, "1. Terra (crucifixão, sepultamento); 2. Inferno (descida, estada de "três dias"); 3. Céu (subida do Inferno no terceiro dia, ressurreição e exaltação, nesse momento, à direita do Pai) /.../ a Ressurreição no terceiro dia não está representada como saída do túmulo, mas do Inferno"591. Conclui daí a importância de se estudar a descida aos Infernos para uma compreensão adequada da Ressurreição de Jesus.

\footnotetext{
${ }^{587}$ Ibid. p. 146.

588 Ibid.

${ }^{589}$ Ibid. p. 148.

${ }^{590}$ Ibid. p. 148. Apesar dos argumentos apresentados nas citações que acompanham o texto (notas 62 a 67), considerando o que já expusemos, a afirmação nos parece um pouco exagerada, particularmente no que se refere aos textos bíblicos e aos Símbolos. Concordamos, porém, com a afirmação da importância do tema na "tradição patrística e representações iconográficas orientais" (nota 63).

${ }^{591}$ Ibid. p. 150
} 
A afirmação da descida de Cristo ao inferno nos revela primeiramente uma mudança na compreensão da própria morte. Esta não é simplesmente um "fenômeno biológico e instantâneo /.../ o drama de um instante"

um desenrolar temporal. Morrer é seguramente dar o último suspiro, mas é também (e principalmente?) entrar (e ficar) na morada dos mortos (o Xeol, o Hades15). A morte não é o drama de um instante, ela é um acontecimento que consiste, se assim se pode exprimir, em 'viver a vida dos mortos'. Decerto, bem se sabe, a carne que se decompõe agora no túmulo um dia expirou de velhice, pereceu afogada ou queimada, sucumbiu à doença. Mas a morte não pára nisso nem nesses fenômenos imediatos: o ser que somos não desaparece, ele volta na morada da morte a viver uma vida, mais ou menos sinistra e miserável, como 'almas penadas', num país sem retorno e ausente de significação ${ }^{593}$.

Referindo-se a Jesus, a afirmação da descida ao inferno significa que ele “realmente conheceu a morte, a 'verdadeira' morte, em toda sua verdade, 'durante três dias' /.../, não foi dispensada dela, viveu-a com todos os seus tormentos, que não se limitam às dores físicas da Cruz"594. Tal acontecimento segue a lógica da encarnação, pela qual Jesus desce "a esse lugar de desolação, afastamento dos seres humanos (já não se está na terra) e de Deus (não se está no Céu)”595.

Por isso, só a afirmação da descida ao inferno é capaz de dar à Ressurreição seu alcance real:

\begin{abstract}
Mas eis então o drama da morte de Jesus mais bem valorizado do que de qualquer outra maneira. E já se adivinha o que isso vai significar para uma melhor compreensão da Ressurreição. É com efeito desse estado, desse lugar onde a morte exerce seu poder (ver o krateisthai, estar sob o poder de alguém, de At 2,24) que Jesus vai ser "despertado", erguido, ressuscitado, libertado. É algo totalmente diferente e mais do que simplesmente ressuscitar do túmulo - o que no fundo seria apenas a conseqüência empírica: "Vede, ele não está aí" (ver Mt 28,6).29 E que, aliás, não é vivido como uma descoberta de Jesus: "Alguns de nossos companheiros foram ao túmulo e o que encontraram estava conforme com o que as mulheres tinham dito; a ele, porém, não o viram" $(\operatorname{Lc} 24,24)^{596}$.
\end{abstract}

Desse modo, "Cristo ressuscitado é o Cristo que sai da morada dos mortos, do estado (do lugar) assinalado aos mortos, isto é, da verdadeira morte"597. "Jesus sai vitorioso da morte saindo do Inferno, ressuscitando do Inferno: aí é o lugar da

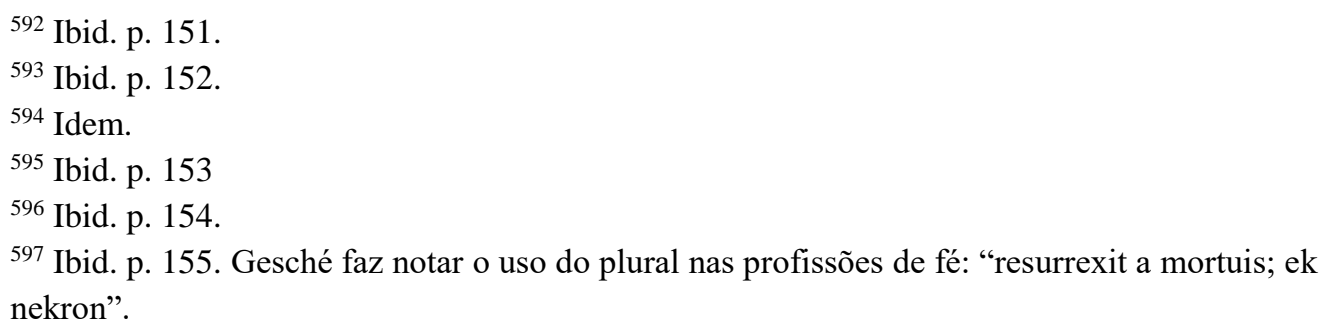


Ressurreição vitoriosa. Venceu a morte em seu próprio terreno (Thanatoi thanaton patesas, venceu a morte pela morte, venceu a morte em seu próprio espaço") ${ }^{598}$.

Como nota corretamente o autor, a afirmação da descida ao inferno "dá à Ressurreição uma densidade maior do que o faz qualquer outra representação ou conceitualização" 599 , evitando-se que seja entendida como um mero ato "prodigioso" ou miraculoso, uma mera revitalização pessoal. Faz com que a Ressurreição seja entendida como deve, "uma vitória contra a morte, e não simplesmente, se se pode dizer, contra uma morte, contra tal morte" ${ }^{\prime 600}$.

Após lembrar, com muito bom senso, que não se deve tratar as representações simbólicas além do que elas podem ${ }^{601}$, Gesché passa a analisar e retoma as representações tradicionais da descida de Cristo ao Inferno: "um combate contra o demônio", "a pregação aos acorrentados" e "a saída vitoriosa".

Com relação a primeira, pretende "captar o significado, como salvação, dessa representação da vitória sobre o Inferno".

\footnotetext{
${ }^{598}$ Ibid. p. 156.

${ }^{599}$ Ibid.

${ }^{600}$ Ibid. p. 157.

${ }^{601}$ Reproduzimos duas notas em que o autor trata do tema, por julgá-las de especial importância: nota 94 (p. 157) Mesmo se, com são João, dizemos que Jesus ressuscitou na Cruz e que com alguns dizemos que é como ressuscitado que Cristo desceu ao Inferno, isso não é ponto de fé. Ao contrário, a fé tenderia a exprimir-se dizendo que ressuscitou no terceiro dia (é a insistência mais frequente). Quanto a outras apresentações ainda, como a que diz que Jesus foi ao Inferno somente com sua alma (teoria tardia, inspirada na antropologia grega e sem dúvida imaginada para harmonizar a Descida ao Inferno com a estada do corpo no túmulo); ou como a que diz que Jesus visitou o Inferno com seu corpo ressuscitado, eu seria tentado a dizer que pouco importa (ver Jo 21,22-23, 'que te importa'; 2Cor 12,2-3, 'eu não sei', 'Deus o sabe'): só a subtileza dessas apresentações (para não falar de outras ainda) já é mau sinal. O que importa é que Jesus entrou como salvador no Inferno e que 'basta' (!) que o tenha feito como Deus e como ser humano, em seu estado de Encarnação, prolongando o que fez na Palestina". E nota 108 (p. 164): "Retorno a essa questão (ver a nota 3, p. 175). Muito se discutiu para tentar saber se o Senhor desceu morto ou já ressuscitado, apenas com sua alma ou também seu corpo, apenas segundo sua divindade ou também com sua humanidade. Toda opinião é possível. Parece-me, salvo meliore judicio, que se pode muito bem admitir que Jesus 'entra no Inferno', isto é, conhece até o fim a morte, como morto. Não é somente 'no terceiro dia' que ressuscita dentre os mortos? Que ele não tenha entrado como ressuscitado, não é isso que impediria, uma vez que ele é o Deus da vida, de salvar os seres humanos aprisionados. Em todo caso é nesse ponto que é preciso ficar vigilante e não tratar as representações além do que elas podem. Somos, neste estudo, contra uma minimização do tema da Descida ao Inferno; não gostaríamos que se caísse no outro excesso, o da maximização.
} 
Que nos diz ela? Que, depois de sua morte na Cruz, Cristo prossegue, no último reduto do mal (do Maligno), a luta contra o pecado, o mal e a morte, começada na Encarnação, continuada na vida pública (pregação da salvação, curas; perdão dos pecados) e culminando na terra com a Paixão e a Cruz. Mas esse combate não estava terminado, devia acabar num último combate contra o mal em seu próprio espaço, o Inferno, lá especificamente onde ele reina quase sem constrangimento, "na casa dele", o Adversário, o Mau, personalização do mal radical (Hb 2,14). É a obra da Encarnação e da Redenção que tem prosseguimento ${ }^{602}$.

A descida ao Inferno nos fala que a Ressurreição não deve ser como um mero "prodígio", mas como uma "vitória", que vence o mal, não apenas como "mal moral"; antes como vitória sobre o mal, como "erro de destino", "perda do acesso à Árvore da vida":

o combate do Senhor vai até as raízes destinais, não simplesmente morais, do mal que corrompe a vida, e que esse combate do Salvador pela vida deve desembocar em vitória contra o que impediu o acesso à Vida, contra o que fechou o acesso àquilo que constitui o fim e o destino do ser humano. $\mathrm{O}$ combate do Príncipe da Vida contra o príncipe da morte (Jo 14,30), que detém a vida como refém, deve reabrir o acesso à Vida ${ }^{603}$.

Como "pregação aos acorrentados" (fundamentando-se em 1Pd 3,18-20;

4,6) Gesché entende a descida de Jesus ao Inferno como oferecimento universal da salvação:

a Pregação, a Paixão e a Cruz são propostas a todos os seres humanos, como o foram aos contemporâneos da Palestina. E notemos, vale a pena sublinhar, que essa Pregação aos acorrentados não se dirige somente aos justos do Antigo Testamento, mas também aos pecadores (Pedro fala dos "rebeldes"), o que acentua o caráter salvífico da Descida ao Inferno. Todos os Antigos (e não somente os Justos, como se repete muito freqüentemente) vão poder beneficiar-se da Revelação salvífica de Deus em Jesus e aderir (ou não) pela fé à sua mensagem ${ }^{604}$.

Trata-se da tal vitória sobre o Inferno que este "é aniquilado, não existe mais". Por fim, Gesché aborda a "saída vitoriosa"605 de Cristo do Inferno, o "aspecto agônico da Ressurreição" (expressão que dava título ao artigo anterior: "L'agonie de La Resurrection ou La Descente aux Enfers"). Afirma que a descida ao Inferno manifesta o sentido soteriológico da Ressurreição.

\footnotetext{
${ }^{602}$ Ibid. p. 163.

${ }^{603}$ Ibid. p. 163-164.

${ }^{604}$ Ibid. p. 165.

${ }^{605}$ Em nota já havia esclarecido que “falando de 'Descida ao Inferno', será preciso quase sempre ter em mente ao mesmo tempo: 'Estadia no Inferno' e 'Saída do Inferno'. Conservaremos o uso corrente, que afinal faz sinédoque" (nota 61; p. 148).
} 
Deixando a morada dos mortos, como mostram magnificamente os ícones em que ele tira Adão e Eva pelos punhos ${ }^{606}$, Jesus arrasta vitoriosamente no seu próprio acesso à Vida - ao mesmo tempo que a si próprio - aqueles que estão mortos. A ressurreição de Jesus é, ao mesmo tempo, sua ressurreição e a dos outros. Não é somente uma vitória pessoal ("Deus o livrou dos tormentos da morte"), mas uma vitória que "empunha" aqueles que estavam já mortos e vítimas da perdição (Unheil). Jesus, ressuscitando, é ao mesmo tempo o Ressuscitado e o Ressuscitante, aquele que é arrancado e aquele que arranca do Mal e da morte, para arrastar vitoriosamente à Vida aqueles que estavam afastados dela ${ }^{607}$.

Revela, assim, o caráter combativo, agônico (de agon = combate) da Ressurreição, que a constitui como parte integrante do Mistério da Redenção, não podendo ser considerada uma mera recompensa, que Jesus recebe pela morte que passou.

Eu não sou o Deus dos mortos, mas dos vivos" (Mt 22,32). O Filho desse Deus dos vivos é aquele que vem dar prosseguimento a essa afirmação: "Eu sou a Ressurreição e a Vida" (Jo 11,25).77 Pelo recurso que faz ao vocabulário da Força da Direita do Pai e do Poder do Espírito no momento da Ressurreição, a Escritura remete a todo o vocabulário da Criação, apresentada, ela também, como ato da onipotência de Deus. Foi preciso força e esforço (foram necessários "seis dias") para criar. Da mesma maneira ("Eu acabei a obra" do Pai [Jo 17,4]), foi preciso força e poder (foram necessários "três dias") para tirar Jesus da morte e para que este tirasse os mortos da morte, restituindo assim o acesso à (Árvore da) Vida. É o que temos chamado, por isso, a agonia da Ressurreição, desde o jardim de Getsêmani até o terceiro dia, quando da saída do Inferno. Mas como essa agonia está aureolada de glória! ${ }^{108}$

\section{8 - Um teólogo brasileiro: Leonardo Boff.}

O tema da descida de Cristo aos infernos não tem grande presença na teologia latino-americana. Encontramo-lo apenas na obra Vida para além da morte $^{609}$ do teólogo brasileiro Leonardo Boff.

Ao admitir os textos que classicamente se referem ao descensus ${ }^{610}$, como fundamento da doutrina contida no Credo, Boff precisa que Jesus não desceu ao

606 Cf. figura 6 p. 290, o magnífico afresco do sec. XIV de Kariye Cami, Istambul (in. PASSARELLI, G., Iconos. Festividades Bizantinas., 1999, p. 19). Esse caráter de vitória 'exigindo esforço' é salientado ainda pelo fato de que Cristo segura os protoparentes pelos punhos, para que não corram o risco de escorregar, caso fossem puxados apenas pela mão, garantem-nos os iconólogos. (Gesché, op. cit.. nota 119, p. 167)..

${ }^{607}$ Ibid. p. 166.

${ }^{608}$ Ibid. p. 172.

${ }^{609}$ BOFF, L. Vida para além da morte, 1973. 
inferno ("que é a radical ausência de Deus, a situação dos que a si mesmos e voluntariamente se isolaram de Deus e de Cristo" ${ }^{611}$ ), mas aos infernos ou Hades, que "constituíam para o mundo antigo a situação de todos os mortos" ${ }^{612}$. Desse modo, o significado primeiro e óbvio da afirmação da descida de Cristo aos infernos "é ressaltar a realidade da morte de Cristo. Na representação mítica da época, Cristo, com sua morte desceu aos Hades. Morreu de verdade e participou da sorte de todos os mortais" $"$.

A doutrina da descida de Cristo aos infernos adquire, porém, um significado especial dentro da compreensão específica que Boff tem da morte, "como crise radical, de-cisão e juízo"614 e como "cisão e passagem" entre "um tipo de corporalidade limitado, biológico, restrito a um pedaço do mundo, i.é, ao nosso 'corpo' e outro tipo de corporalidade em relação à matéria ilimitado, aberto, pancósmico que corresponde ao novo modo de ser em que entra o homem após a morte, a eternidade" ${ }^{\natural 15}$.

Em relação à morte como crise, a doutrina da descida de Cristo aos infernos, significa afirmação de sua radical solidariedade com o homem:

${ }^{610} \mathrm{O}$ Novo Testamento faz algumas afirmações verdadeiramente surpreendentes sobre uma descida de Cristo aos infernos. Id. 184. Os textos citados pelo autor são 1Pd 3,19; 4,5-6; At 2,31; Rm 10,7; Ef 4,9-10; Ap 1,18; Fl 2,10 (pp. 184-185). Já vimos a dificuldade em relacionar estes textos com a afirmação de uma descida de Cristo aos infernos.

${ }^{611}$ BOFF L., op. cit. p. 185

${ }^{612} \mathrm{Id}$.

${ }^{613} \mathrm{Id}$.

${ }^{614}$ Segundo Boff, na morte é dado ao ser humano a capacidade de optar por Deus ou contra Ele: Todo homem se encontrará face a face com Deus e com o Ressuscitado, mesmo que em sua existência nem sequer lhes tenha ouvido os nomes. Num momento a todos é oferecida a chance de ser cristãos, de optar por Deus e por Cristo" (p. 47). "Nesse momento de total desmascaramento do homem diante de si mesmo pode dar-se também uma total con-versão. Ainda uma vez lhe é oferecida a chance e ele pode decidir-se para a abertura total de si ao Absoluto e à totalidade da realidade criada. (Idem,p. 50).

${ }^{615}$ BOFF, L. op.cit. p. 39; Ainda: Morte não significa um abandonar do mundo, mas um assumi-lo de forma mais integradora. A globalidade da realidade não constitui uma justaposição disparatada de elementos.Preside-a uma unidade radical; há um coração que unifica tudo num sentido realontológico, não só física, mas também psicológicamente. $\mathrm{O}$ homem se encontra num enraizamento ontológico com o mundo, pois, ele é, na verdade,um espírito encarnadona matéria. Esse seu estatuto natural jamais o perde. Na morte, ele se potecializa mais e mais. Por isso, a morte não é só perda. É ganho ontológico numa união mais profunda com o ser material., Idem, p. 189. A nós, parece evidente a relação do pensamento de Boff com o de K. Rahner, que acima apresentamos. 
O homem teme a morte, porque teme o vácuo. /.../ Cristo, ao morrer, participou da situação humana mortal. /.../ Encarnou não só a vida com tudo o que ela significa de possibilidades de encontro, de amor, de crescimento, mas também a morte com tudo o que ela implica em aniquilação, abandono e solidão. 'Mas aquele que desceu é também aquele que subiu' (cf. Ef 4,10). Se desceu, foi para nos assegurar: não temais; eu tenho as chaves da morte; eu venci a morte; eu passei pela porta da última solidão; lá onde não havia nenhuma presença, estou eu; lá onde não se houvia nenhuma palavra, está minha voz; lá onde havia um derradeiro abandono, está o meu aconchego; lá onde reinava a morte mora a $\operatorname{vida}^{616}$.

A descida de Cristo aos infernos é a afirmação da possibilidade de salvação, oferecida a todas as gerações, também no tempo antes de Cristo:

São Pedro diz ainda que a boa-nova foi anunciada aos mortos para o seu julgamento (1Pdr 4,5-6). Essa afirmação pode muito bem ser interpretada dentro da concepção da morte como decisão final e radical do homem. Aí se realiza o grande encontro com Deus e com a graça de Jesus Cristo. Isso vale para todos os homens As crianças inocentes que morreram antes de qualquer decisão livre, ao morrer, entram na situação da 'pregação de Cristo aos mortos nos infernos'. Com isso afirmamos: elas também não estão fora da salvação trazida por Jesus Cristo; é por Ele que são salvas ${ }^{617}$

Em relação à morte como "penetração do homem /.../ no coração da matéria" ${ }^{\circ 18}$, a afirmação da descida de Cristo aos infernos significa a mudança ocorrida na criação com o ato salvador de Jesus Cristo, a "transfiguração do cosmos":

Com sua morte, Cristo 'penetrou no coração da terra' (em te kardía tes gés: Mt 12,40). Ele a penetrou enquanto Deus encarnado. A matéria, a partir da morte e ressurreição de Cristo, conquistou assim uma nova dimensão que antes não tinha: dentro dela germina e fermenta uma nova realidade, atuante e viva, tudo repletando e levando para uma meta final. /.../

Como Ressuscitado, Cristo está no mundo, em seu cerne em suas camadas mais ínfimas (infernos). Começou a transfiguração dos cosmos Essa compreensão nos esclarece o significado da afirmação da fé na instrumentalidade universal da humanidade de Cristo. Penetrando o mundo, Ele é o sacramento universal de todos os homens, por que todos estão ligados ao mundo. Todos os homens assim estão em contacto, consciente ou inconscientemente, com o Cristo. Ao morrer, quando o homem penetra no coração da terra, se encontra com a presença do Senhor ressuscitado e cósmico. Aí se dá a grande decisão e o grande encontro ${ }^{619}$.

\footnotetext{
${ }^{616}$ Id, p. 186.

${ }^{617}$ Ibid. 189.

${ }^{618}$ BOFF, L. op. cit. p. 189.

${ }^{619}$ BOFF, L. op. cit. p. 190. Também aqui é perceptível à relação com o pensamento de Karl Rahner, citado na bibliografia pelo autor.
} 
Não se pode negar que Leonardo Boff tenta aproximar o imaginário teológico da própria realidade ou até mesmo da própria obra criada. Não somente, a Descida de Cristo à mansão dos mortos, numa perspectiva pancósmica, mas encontramos outras referencias de uma aproximação histórica. A Trindade, por exemplo, significou toda uma construção a partir de pessoas de diferentes épocas, culturas e condições sociais e econômicas, que reconheceram e usaram as expressões que a teologia construiu e elaborou sobre a Trindade. O próprio Leonardo Boff afirma que "a rigidez das fórmulas trinitárias e os rigores das expressões teológicas ficaram para o uso dos eruditos da fé cristã’"620.

Entre a realidade teórica e conceitual, que a teologia definiu, pode-se dizer que parcelas significativas não necessariamente tenha se perdido, obviamente não só ficaram desconhecidas ou foram ignoradas, mas é possível que tivesse ocorrido uma associação destes conceitos teológicos com o imaginário das pessoas e estas se inseriram no contexto coletivo e imaginário, por isso, Boff afirma: “Os próprios santos Padres quando abordaram, em suas longas e ardorosas discussões, suas perspectivas teológicas, não deixaram de trabalhar sobre analogias, figuras e imagens ${ }^{621}$.

${ }^{620}$ BOFF, L. A Trindade e a Sociedade, o Deus que liberta o seu povo. 3.ed. Coleção Teologia e libertação. Petrópolis: Vozes, 1987, p. 129 ${ }^{621} \mathrm{Id}$. 


\section{Capítulo IV - A descida aos infernos como modelo para a atuação da Igreja}

Ao analisarmos o artigo de fé da descida de Cristo à mansão dos mortos, podemos perceber que este é carregado de imagens e simbolismos. Não se pode negar que estas imagens e símbolos podem dar um significado e ajudar de uma forma ou de outra na compreensão da fé. A fé procura a inteligência para melhor entender a mensagem evangélica. A teologia ocupa-se de Deus e do homem, fazendo com que, a relação entre ambos, no plano da salvação, tenha relevância ao homem em sua globalidade e razão última. Compreender a ação de Deus na história requer uma hermenêutica, uma interpretação e uma atualização ${ }^{622}$, para que se possa desenvolver uma atuação na Igreja.

A teologia como ciência da fé, deve partir primeiramente do Evangelho, para que se possa obter uma visão integral do homem. Se partirmos primeiramente de uma visão do homem, teremos uma compreensão deturpada ou truncada da própria teologia, assim, os resultados poderiam ser nefastos. O objetivo principal em atribuir a teologia como ciência da fé é procurar apoiar as ciências humanas, para melhor orientar e aprofundar a mensagem revelada ${ }^{623}$.

Desta forma, se percebermos a teologia como ciência de fé, vinculada a outros métodos científicos de pesquisa (filosóficos ou até mesmo literários), podemos tentar apresentar uma hermenêutica do artigo de fé da Descida de Cristo aos Infernos. Ao acolher este artigo de fé, mesmo sendo uma expressão literária carregada de imagens e simbolismos, podemos atribuir uma reflexão sobre a história e sobre o engajamento prático no processo histórico contemporâneo. $\mathrm{O}$ dado de fé, já presente nas primeiras comunidades cristãs, mesmo que não corresponda com nossa realidade histórica, nos serve para atualizarmos de acordo com o contexto atual em que vivemos. Assim,

A esperança cristã, com toda a sua dinâmica em nossa práxis hoje, enraíza-se neste 'fato', neste dado objetivo. Enraiza-se na fé no Senhor Jesus como acontecimento

622 TEPE, V., Estamos Salvos, São Paulo, Edição Paulinas, 1982, p. 113.

623 Ibid. 112-114. 
histórico que nós não re-lemos ou interpretamos na luz de nossa práxis atual, mas que nós acolhemos como verdade que ilumina nossa vida e nossa práxis hoje. Esta verdade nos é transmitida de geração em geração a partir das testemunhas oculares, os apóstolos. Já são Paulo se coloca na corrente dessa transmissão: 'o que recebi, eu vos transmiti' $(1 \text { Cor } 11,23)^{624}$.

Esta "atualização", hermenêutica, pode ser conferida na história porque a fé nos fala algo sobre a história do indivíduo ou de uma sociedade ${ }^{625}$. Ela, a fé, nos dá uma característica da pessoa humana que nenhuma ciência pode oferecer: a meta história. Uma meta que é trans-histórica. Assim, como a meta da vida individual de Jesus, sua ressurreição é trans-histórica ${ }^{626}$.

${ }^{624}$ TEPE, V., Estamos Salvos, São Paulo, Edição Paulinas, 1982, p. 120.

${ }^{625} \mathrm{O}$ cristianismo não é um resumo de verdades teóricas ou práticas, não é um sistema filosófico ou ideológico: é fé. Fé numa verdade histórica que se tornou o fundamento de tudo. Esta verdade histórica chama-se Jesus Cristo, morto e ressuscitado. 'E ninguém pode lançar fundamento diverso do que já foi colocado: Jesus Cristo' (1Cor 3,11); Ibid., p. 121; O mito vem do grego $\mu v \theta$ os (mithós), que significa uma narrativa com caráter simbólico e ilustrativo, em geral relacionada à determinada religião ou cultura. $\mathrm{O}$ mito tem como objetivo explicar os acontecimentos cotidianos, os fenômenos naturais e a origem do universo e do homem. $\mathrm{O}$ mito usa a imagem de criaturas sobrenaturais - deuses, semideuses e heróis - para tentar explicar a realidade ${ }^{626}$ Ibid., p. 114. 
É evidente que estas imagens e figuras simbólicas que o símbolo de fé foi adquirindo, podem ter em si uma linguagem uma lógica própria. ${ }^{627}$ Longe de considerá-los simplesmente como meras ilusões ou estórias, ${ }^{628}$ contadas por determinados povos, para justificar uma ausência de resposta, este simbolismo pode ter uma função pedagógica e esclarecedora ${ }^{629}$.

Este sentido pedagógico, na tentativa de um esclarecimento da existência,

${ }^{627}$ Leonardo Boff descreve a importância da linguagem mitológica e nos mostra que é possível desenvolver uma hermenêutica para tentar responder as situações da própria realidade. Os mitos são linguagem para traduzir fenômenos profundos, indescritíveis pela razão analítica, podendo ser expresso, ao falar do namoramento, do amor, do cuidado essencial, da tradição da pessoa amada, das crises da vida, das doenças incuráveis, do nascimento e da morte senão com emoção. BOFF, L., Saber cuidar: Ética do humano - compaixão pela terra, 2017, p. 37; Leonardo Boff justifica uma interpretação mitológica com apoio da psicologia quando diz: O Inconsciente se estrutura em mitos e arquétipos, símbolos e imagens. Mito para a psicologia não significa, como para a história das religiões, estórias de deuses ou contos fantásticos de seres supraterrenos com seu destino, lutas, derrotas e vitórias de heróis. Mito é a forma como o Inconsciente coletivo representa para si o sentido radical das situações permanentes da vida em relação com Deus, com o pai, com a mãe, com a mulher, com o homem, com o rei, com o sacerdote, com os animais, com o homem, com o mal, com o sexo, etc. O mito possui estruturas, linguagem e lógica próprias. Não é absurdo ou arbitrário, embora o possa parecer para a razão analítica do consciente, que se orienta na verificação dos objetos. Nele fala o Inconsciente e não o consciente. Daí que a pesquisa meramente 'científica', 'objetiva' dificilmente entende o mito porque o aborda com categorias hauridas da vida consciente. BOFF, L., Jesus Cristo Libertador, 1972, p. 35-36.

${ }^{628}$ A verdade do mito não reside também na sua realização 'objetiva', no mundo da realidade. A pesquisa 'científica' e 'crítica' que procedeu assim desqualificou de imediato o mito como fábula e ilusão. O erro, porém, não está no mito, mas no estudioso que falseou totalmente a perspectiva na ilusão de que o homem é unicamente racionalidade e vida consciente. O consciente e o mundo dos objetos, bem como dizia S. Freud, formam apenas a ponta saliente do iceberque que em sua grande maioria se esconde debaixo da água (Inconsciente). Desmitização não significa o desmascaramento do mito confrontado com a realidade objetiva, o que seria não compreender o mito, mas dar-se conta do mito como linguagem do Inconsciente, aceita-lo como uma forma legítima de compreensão lógica e integrá-lo no processo de individuação da personalidade. Buscar o sentido do mito não é detectar sua origem genética, se veio dos persas ou dos gregos, nem decifrar as tradições que o configuraram. O sentido e a verdade do mito residem na força interpretativa que possui no esclarecimento da existência. BOFF, L., Jesus Cristo Libertador, 1972 , p. 36.

${ }^{629}$ Estimamos que as mitologias, mais que as ciências e as filosofias, encerram, junto com as religiões, os grandes elucidamentos da essência humana. Aí as culturas projetaram, geração após geração, grandes visões, acumularam reflexões, fizeram aprofundamento e os passaram a seus pósteros. Souberam usar de uma linguagem plástica, com imagens tiradas das profundezas do inconsciente coletivo, acessível a todas as idades e todos os tempos. Além das visões e dos símbolos, suscitam e continuam suscitando grandes emoções. E são essas que ficam e mobilizam as pessoas e os povos na história. (...); As deusas e os deuses mitológicos não devem ser considerados como existentes em si mesmos, seres substanciais e independentes de nossa existência. Configuram arquétipo do inconsciente coletivo, vales dizer, centros de grande energia e significação, que somente através da linguagem dos heróis e das heroínas, dos deuses e das deusas podem ser expressos adequadamente. São figuras carregadas de emoção, feitas referências paradigmáticas e inspiração mobilizadoras para os comportamentos humanos. (...);Entendidas como forças espirituais poderosas, as múltiplas divindades representam os mútuos centros energéticos e as diferentes fontes de sentido que estruturam a interioridade humana. BOFF, L., Saber cuidar: Ética do humano - compaixão pela terra, 2017, p. 37-38. 
nos permite perceber que determinados artigos de fé ${ }^{630}$, como a Descida de Cristo aos Infernos, tem uma mensagem, uma linguagem, e um método que dá sentido a iniciativa salvífica promovida por Jesus.

Com efeito, para a Teologia Latino-americana, este artigo de fé da Descida de Cristo aos infernos, pode desempenhar uma nova forma de pensar ${ }^{631}$. Haveria uma correspondência em "Descer" aos mais pobres, estar presente aos mais oprimidos, aos injustiçados, àqueles considerados invisíveis na sociedade. Se compreendermos a iniciativa divina em levar a Salvação, o anúncio da Boa Nova e da Solidariedade na região mais inferior da terra, as periferias existenciais se tornam o palco para esta iniciativa cristã.

Jesus, o Cristo, esteve presente na história, compartilhou do sofrimento humano, das angústias do homem. A Salvação só poderia ser conferida no âmbito da história humana ${ }^{632}$. Assim sendo, toda a iniciativa cristã exerce uma prática que corresponde às ações de Jesus, ou seja, uma salvação que tem início na história pelo anúncio da Boa Nova, mas que ainda esperamos pela irrupção do Reino de

\footnotetext{
${ }^{630}$ Enquanto, porém, o mito não se realizar para todos os homens e para o cosmos ele não poderá ser totalmente desmitologizado e desilusionado. Nessa perspectiva há preciosas intuições que vêm esclarecer pontos obscuros e de permanente compreensão na mensagem de Jesus, como o anúncio iminente da vinda do Reino, o conflito com a lei e outros. BOFF, L., Jesus Cristo Libertador, 1972, p. 37.

${ }^{631}$ Concretamente, no caso da maioria de nossos cristãos latino-americanos, torna-se indispensável uma reformulação da fé, uma espécie de 're-mitificação', para que eles se tornem capazes de ser cristãos em um mundo no qual muitas das velhas expressões da fé se encontram superadas. $\mathrm{O}$ problema não é tanto o de se é possível ou não falar da mensagem cristã sem terminologia mítica, mas sim o de que a maioria das expressões míticas usadas começam a cair em desuso, deixando de ser instrumento de compreensão e comunicação vital. Não há dúvida de que teólogos como Teillhard de Chardin conseguiram expressar o conteúdo da fé cristã em moldes novos, poéticos e talvez até míticos, ajudando os homens de hoje a fortalecer sua fé e expressá-la em termos atuais e de elevada significação. Hoje, nossos povos latino-americanos necessitam de algo semelhante. (...) Talvez, com esses novos moldes, a fé renasça e recobre seu dinamismo essencial, que deve ser eterno, pois provém do contato vivificador com Cristo Salvador. Verbete MITO, in: IDÍGORAS, J. L., Vocabulário Teológico para a América Latina, São Paulo: Edições Paulinas, 1983, p. 298. ${ }^{632} \mathrm{O}$ descenso de Deus à história não é captado em sua formalidade abstrata pura aceitando simplesmente o grande prodígio e dom desse descenso, mas quando se observa em que consiste concretamente. E o concreto é Jesus de Nazaré. Não se trata, pois, só de aceitar na fé o prodígio e o dom de Deus se ter tornado um ser humano, mas também é decisivo esclarecer o concreto desse tornar-se. Só isso aponta para o fato, certamente, mas também só isso mostra o significado do fato: a aproximação aos homens por parte de Deus enquanto salvífica, partilhando sua condição até os extremos da cruz. (...) Em outras palavras, é fé que existe um prodígio e dom de Deus que nenhuma cristologia pode demonstrar, pois vem de cima. Mas o que é esse prodígio e esse dom, é coisa a constatar, encontrar-se embaixo, e por isso a cristologia, aceitando desde o princípio a totalidade de Jesus Cristo, pode também começar por aí. SOBRINO, J., Jesus, o Libertador, I A história de Jesus de Nazare, 1996, p. 63, Série II, O Deus que liberta seu povo (Coleção Teologia e Libertação).
} 
Deus $^{633}$.

Se a iniciativa salvífica promovida por Jesus se estende na história, assim como sua mensagem profética e sua ação solidária, fazendo correspondência com as três perspectivas teológicas do "Descensus", é justo que vejamos mais de perto como procedem estas iniciativas. Somente assim, poderemos atribuir uma hermenêutica ao Descensus apresentando uma aproximação de tais perspectivas teológicas, com a realidade da sociedade latino-americana.

Nos textos bíblicos encontramos expressões em que muitas vezes as conhecemos a partir de leituras bíblicas, em menções de algumas obras ou artigos científicos, mas que, geralmente nos fogem a ideia daquilo que nos podem representar. Cada expressão tem um sentido terminológico em que corresponde com sua cosmologia, história e sua forma de pensar. Expressões tais como, Sheol, Hades, Inferos, Refaim, são expressões que se referem a um pós-morte e que dentro de um estudo bíblico-teológico pode despertar interesse em saber como o povo hebreu, ou até mesmo as primeiras comunidades, pensavam o pós-morte. Em vista disso, colhemos estas expressões, no mínimo curiosas, que dentro de seu contexto histórico teve sua relevância, mas com a ajuda da hermenêutica podemos tentar estender seu significado aos inúmeros desafios presentes em nossa sociedade.

\footnotetext{
${ }^{633} \mathrm{O}$ cristianismo se apoia em um fato histórico que dá significado à história inteira: Cristo Jesus, que viveu entre nós, morreu e ressuscitou. Embora a experiência profunda das testemunhas tenha sido narrada num estilo antigo, no qual não faltam elementos míticos, isso não pode levar à exclusão do caráter central do acontecimento histórico de cristo. Hoje, mais do que nunca, trata-se de superar um cristianismo intimista, reduzido à própria vivência interior e desligado das consequências sociais na história. Além disso, deve-se levar em conta que é quase impossível falar das realidades religiosas, da fé e de Deus sem utilizar uma linguagem próxima ao mítico. As palavras que transmitem a mensagem religiosa da fé não expressam somente acontecimentos que se podem comprovar, mas penetram regiões em que a linguagem deve-se fazer de certa forma simbólica e mítica para expressar o encontro com Deus e seu Reino. Verbete MITO, in: IDÍGORAS, J. L., Vocabulário Teológico para a América Latina, São Paulo: Edições Paulinas, 1983, p. 298.
} 


\section{1 - O "lugar dos mortos" à luz da teologia latino-americana}

Muitos cristãos expressam sua fé afirmando que Jesus "foi crucificado, morto e sepultado, desceu à mansão dos mortos..." Se as afirmações referentes à crucifixão, morte e sepultamento do Senhor não causam problemas, e são mais facilmente compreensíveis, a afirmação seguinte parece obscura - que "mansão dos mortos" é essa, que fala o Credo? A obscuridade aumenta ainda mais quando traduzindo literalmente do latim (descendit ad ínferos) se afirma que Jesus “desceu aos infernos”. O que foi fazer Jesus, neste lugar de perdição?

O texto bíblico nos apresenta estes "lugares" após a morte, em que esperava que Deus pudesse tomar sua iniciativa. Com efeito, se Deus também se revela a partir de ações humanas, sendo o homem instrumento nas mãos de Deus para levar a mensagem salvífica, podemos por meio de uma hermenêutica fazer correspondência com as devidas expressões terminológicas de Sheol, Hades, Inferos e Refaim, com a situação do povo latino-americano, nos diversos setores da vida na sociedade ${ }^{634}$.

Desde o Antigo Testamento, encontramos referência da ação de Deus, que poderia se estender àqueles que morreram. Uma das compreensões de morte no Antigo Testamento afirma que aquele que morria descia ao Sheol. O pensamento do povo da Bíblia em relação à morte, em razão de complexidade do tema (Descensus), não era uniforme, mas comportava mudanças e contradições. Desse modo, se em determinadas passagens da Escritura a morte é entendida simplesmente como o fim do humano (S1 55,16; 1Rs 2,6.9; Jó 21,13) e o Sheol, ou

634 A ler algumas considerações da teóloga Maria Clara Bingemer, podemos perceber que a analogia apresentada pela teóloga em muito se aproxima daquilo que queremos apresentar nesta tese, porém, com bases fundamentais são diferentes. Autora, ao afirmar que inferno (no singular), seria o lugar que se vai após a morte, sendo um lugar que se situa abaixo, na região inferior àquela onde acontece à vida, seria o lugar em que carrega consigo o conteúdo tradicional das pregações, como fogo, trevas, demônios que atormentam e torturam os condenados, sede, gemidos e ranger de dentes. Com efeito, quando falamos de Deus, falamos de sua justiça principalmente com os mais oprimidos. É dentro desse contexto que Bingemer faz uma analogia do conteúdo infernal com as aspirações mais fundamentais do ser humano: o peso da opressão, da injustiça, falta de trabalho, situações estas que poderiam ser chamadas de infernais (BINGEMER, M. C., Inferno e Céu: possibilidade e promessa, in: LIBÂNIO, J. B., BINGEMER, M. C., Escatologia cristã, Petrópolis, Vozes, 1985, p. 249, Série III - A libertação na História, Tomo X, Coleção Teologia e Libertação). Em nossa pesquisa, não optamos por uma base escatológica, partindo já de um juízo de Deus, para justificar os maiores anseios da humanidade, mas sim, com base cristológica, partindo do questionamento de qual teria sido a atuação de Cristo após a morte, antropologicamente, como Cristo teria descido à mansão dos mortos ou infernos (no plural) e, por fim, onde, ele teria descido nas regiões inferiores? 
"lugar dos mortos", parece apenas representar o túmulo (Jó 17,13-16), outras passagens parecem aceitar uma forma de subsistência, mais ou menos miserável, após a morte (Ecl 9,5-6; Is 38,18), compreendendo o Sheol como uma planície subterrânea e sombria (Jó 7,9; Gn 37,35), que poderia comportar inclusive alguma forma de organização (Is 14,9).

Se nos períodos mais antigos, se afirmava a total impossibilidade da saída do lugar dos mortos (Jó 7,9), mais tarde se compreendeu que o poder de Yahweh se estende também ao Sheol (Am 9, 1c-2; Sl 139,8), donde só Ele pode fazer sair o ser humano (Sb 16,13). A expressão Sheol, no texto bíblico, quer referir-se à condição de abandono daqueles que morreram no tempo de Israel. Todos aqueles que morriam no Antigo Testamento desciam para uma região escura e tenebrosa. Um abismo profundo, onde não se louvava a Deus e não se tinha acesso aos viventes.

Por analogia, em nossa sociedade, podemos perceber situações que se identificariam aos abandonados no Sheol ${ }^{635}$. No abismo, naquela obscuridade cuja vida parece já não mais existir, se assemelha a condição de vida de tantas pessoas em sua extrema pobreza e miséria. Este povo sofrido se torna incapaz de constituir-se como pessoa digna de direitos e deveres na sociedade.

A analogia que fazemos não é de uma "além-morte", mas de uma morte histórica, de um povo crucificado e sofredor ${ }^{636}$. A morte como pobreza, injustiça é acompanhada pela crueldade. Os mais pobres são aqueles que têm pouco ou nenhum valor na sociedade, por causa de fatores econômicos, raciais e até mesmo

${ }^{635}$ Segundo a posição de Jon Sobrino a compreensão de Sheol demorou a ser formulada em Israel. Israel concebeu Deus, antes de tudo com relação com a vida real e histórica do povo. Israel considerava esta vida presente e terrena como grande dom de Deus. Daí Israel relacionou Deus com a vida e com os vivos, sobretudo com as relações sociais entre os vivos e sua religião foi precisamente dar testemunho desse Deus. O povo tinha que concentrar toda a sua atenção e energia nesta missão histórica e terrena. Daí no início, o mundo dos mortos, o sheol, não ter sido considerado como âmbito de Javé. E para o homem de fé a tragédia de terminar no sheol era deixar de estar em comunhão com Javé, SOBRINO, J., A fé em Jesus Cristo, Ensaio a partir das vítimas. 2000, p. 63, Série II, O Deus que liberta seu povo (Coleção Teologia e Libertação).

636 Daí a linguagem de 'povo', 'povos' etc., que está transida de morte, e não de uma morte natural, mas de uma morte histórica, que toma a forma de crucifixão, assassinato, privação histórica ativa da vida, lenta ou rapidamente. Essa morte, produto da injustiça, é acompanhada pela crueldade, pelo desprezo e, por outro lado, pelo encobrimento. A isso costumo acrescentar que o povo crucificado, além do mais, nega palavra a ela e até nome, e com isso lhe nega existência. O povo crucificado não 'é', e o mundo de abundância impede ou dificulta que 'chegue a ser'. Assim, pode não se interessar - sem má consciência - pelo que ocorre com essas maiorias. SOBRINO, JON, Fora dos pobres não há salvação, São Paulo, Paulinas, 2008, p. 21. 
culturais; estes foram postos a margem da sociedade e excluídos de seus direitos fundamentais. Jesus desce até aos mais pobres e injustiçados, assim como Deus pôde tomar sua iniciativa àqueles que desceram ao Sheol, para levar a esperança como contribuição salvífica.

A expressão Hades, por sua vez, encontramos na obra Fédon de Platão. A definição dada por Platão sobre a expressão Hades nos faz pensar como a cultura grega imaginava ou tentava compreender tanto o pós-morte, como um mundo inferior. Platão, ao ser questionado sobre o pós-morte, afirmou: “a alma, a porção invisível, que vai para um lugar semelhante a ela, nobre, puro e invisível, o verdadeiro Hades, ou seja, o Invisível, para junto de um deus sábio e bom ${ }^{637 "}$.

Por outro lado, dentro de uma compreensão mais teológica a "Descida ao Hades," desenvolveu-se de uma forma efetiva na igreja cristã com o passar dos séculos, talvez numa tentativa de reviver a doutrina pagã do Hades. Dentro do pensamento grego havia um lugar para onde iam todos os mortos - o Hades. Este era dividido em dois setores: o Elísio (para onde iam todos os bons) e o Tártaro (para onde iam todos os maus).

Tradução grega do termo Sheol, o termo - Hades - do Novo Testamento, comporta também diversidade de sentidos, podendo significar tanto um lugar de castigo (Mt 11,23), um lugar intermediário anterior ao julgamento final, onde são reunidos todos os mortos, bons e maus (Ap 20,13), onde o "seio de Abraão" seria o local reservado dos justos (Lc 16, 19-31), ou apresentar-se como uma personificação da morte (Ap 6,8; 20,14).

A afirmação da descida de Cristo ao lugar dos mortos encontra-se em perfeita sintonia com o pensamento bíblico, para o qual a afirmação da morte e da sepultura era o mesmo que afirmar a passagem ao Sheol (ou ao Hades). Ainda que estudos mais recentes levantem dúvidas se o texto de 1Pd 3,18-20;4,6, que

${ }^{637}$ PLATAO, Fedon, XIX Para Platão este nome tem aqui a significação de Invisível, o país do Invisível, o reino das sombras. 'os gregos derivavam a palavra $1 \delta \eta \varsigma$ (Hades) de $\alpha$ e $1 \delta \eta \varsigma$ encontraram nesta palavra a significação de invisível, explicando simplesmente que Hades, como rei dos mortos, mora com as almas destes debaixo da terra, e é por isso invisível aos homens e aos outros deuses. Mas Platão modifica a acepção: Hades é o 'invisível verdadeiro', isto é, a substância invariável, eterna e imperceptível aos sentidos, mas captável pelo espírito, que depois da morte se aparta dos obstáculos da matéria (corpo) e vê diretamente o Hades, isto é, o ser eterno'. (Comentário Coleção os Pensadores - Fedon XIX) 
tradicionalmente se emprega (desde Clemente de Alexandria ${ }^{638}$ ), para afirmar a descida de Cristo ao Hades, outras passagens da Escritura (Rm 10,6-8; Ef 4,8-9; At 2,24-31; Ap 1,17-18) parecem supor tal doutrina. Somente, a partir dos Padres Apostólicos e Apologetas apareceram especulações sobre qual teria sido a atividade de Jesus Cristo, após a sua morte e sepultamento, na morada dos mortos.

Durante a história da igreja muitos tentaram dar uma justificativa sobre a ação de Jesus durante sua descida a um local chamado Hades, entre a sua morte e ressurreição. Neste último caso, o grande problema é definir o que Jesus foi fazer lá.

Desta forma, podemos utilizar da hermenêutica para transportar o conceito de invisibilidade dada ao Hades por Platão para algumas situações que encontramos em nossa sociedade. A aproximação do conceito dado a Hades está na invisibilidade social, fazendo referência a seres socialmente invisíveis, seja pela indiferença ou preconceito, os injustiçados, nos fazendo crer que tal circunstancia atinja muitas vezes aqueles que estão à margem da sociedade. É evidente que estes se tornariam as maiores vítimas da invisibilidade social.

Afirma-se que Jesus, o Redentor, após a sua morte teria “descido às regiões inferiores (Inferos), da terra" (Ef 4,9). Essa expressão apareceu em dois credos da igreja cristã antiga, ainda que com palavras diferentes. A primeira ocorrência está no Credo Apostólico, que tem a expressão latina "descendit ad inferna" (desceu aos infernos), e a outra se encontra no Credo de Atanásio, com a expressão latina "descendit ad inferos" (desceu às regiões inferiores). Em vista deste Descensus (Descida) a pergunta a ser feita é qual teria sido a atividade de Jesus no mundo inferior? Segundo Kelly, este afirma: "Deveria ser observado que após Santo Agostinho é que prevaleceu o hábito ocidental de explicar 1Pedro 3,19 como um testemunho da missão de Cristo aos contemporâneos de Noé muito antes de sua encarnação ${ }^{639}$." Assim sendo, podemos perceber que segundo a tradição haviam aqueles que se encontravam no mundo inferior. Separados e distantes dos vivos, esperavam unicamente uma intervenção do Redentor.

${ }^{638}$ CLEMENTE DE ALEXANDRIA. Les Stromates VI 45-48 (Sch 446). Paris. CERF, 1999.

${ }^{639}$ KELLY, J. N. D., Early Christian Creeds, 1986, p. 379 
Escapar de toda a exploração, opressão, do peso da injustiça, da humilhação de tudo que é capaz de rebaixar, inferiorizar, para viver integralmente a dignidade da pessoa humana ${ }^{640}$. É na falta da dignidade é que encontramos a maior condição de inferioridade humana.

A expressão Refaim está intrinsicamente ligada ao que diz respeito ao mundo inferior. Os prisioneiros da morte são chamados "impotentes" (Refaim), porque não podem fazer nada e não tem nenhuma forma de relação entre si, nem com os vivos, nem com Deus. Porque o Sheol é o lugar da perda de toda a atividade, do abandono e da solidão total, os refains não se lembram de Deus, nem invocam a Deus, nem louvam a Deus "No reino da morte ninguém te invoca e no Sheol quem te louva?" (S1 6,6). "No Sheol para onde irás, não há nem obra, nem pensamento, nem saber, nem sabedoria" $(\operatorname{Ecl~9,10).}$

Sobre este mundo inferior, podemos perceber que as ideias judaicas não são tão homogêneas em toda a história do Antigo Testamento. É certo que percebemos uma aproximação com a antropologia. Assim sendo, encontramos na antropologia judaica dois padrões antropológicos, um que diz respeito aos vivos, e outro aos mortos. Ao primeiro faz-se referencia ao Basar, Nefesh e Ruah, que expressam definitivamente uma unidade. Desde que não se permitia expressar a ideia de sobrevivência humana após a morte, o Nefesh e Ruah não poderiam existir fora do homem.

Ao segundo, para tornar possível falar de uma sobrevivência dos mortos foi usado outro padrão, formando uma distinção antropológica entre os cadáveres e os Refaims por um lado, e o Sheol e o sepulcro por outro (cf. Gn 23,19; 37,35; 49,29-33). Trata-se de uma sobrevivência que não era um aniquilamento, não é nem mesmo uma existência de almas, no sentido moderno da palavra. Os Refaims levavam uma vida sombria, sendo algo semelhante das sombras do homem, tratase mais de um núcleo pessoal do que uma realidade oposta ao corpo terrestre. Pode-se dizer também que paradoxalmente, os Refaims são os corpos sem alma.

\footnotetext{
${ }^{640}$ La teología de la liberación, en sus instancias válidas, encuentra así un marco de referencia más amplio y completo, que recupera algunos elementos propios, pero sobre todo los coloca en un contexto que los hace eficaces para una salvación auténtica y duradera. RATZINGER, CARDENAL JOSEPH, Jesucristo Evangelizador, in: Iglesia in América, Al encuentro de Jesucristo vivo, 2001, p. 57-58.
} 
Os corpos que não tem peso e nem sustento. Tal existência dos defuntos pode ser expressa também mediante o conceito de sono, coisa que implica também a impossibilidade de expressar qualquer retribuição. Este modo de viver ainda não está ligado à esperança da ressurreição ${ }^{641}$.

Com efeito, não é difícil perceber a relação desta impossibilidade de se expressar, esta inatividade presente nos Refaims, com algumas situações concernentes em nossa sociedade. Tais situações são visíveis muitas vezes quando uma pessoa tenta se esquivar de um processo de exploração ou de opressão, mas, muitas vezes, alienada por diversos fatores não consegue meios suficientes para uma mudança de vida.

Se até então conseguimos fazer uma hermenêutica aos termos Sheol, Hades, Inferos e Refaim, procurando perceber através da etimologia expressões que se identificam com os desafios do cotidiano do homem, podemos aos poucos mostrar que a esperança e a vida também são possíveis como uma meta a ser atingida no seio da humanidade.

Se de tais expressões Sheol, Refaim, Inferos e Hades, muitas vezes fizeram referencia ao pós-morte ou talvez com a própria morte, por outro lado, viver e esperar que esta vida seja abundante se torna o desejo de todo o ser humano. Com isso, não era de se estranhar que apesar de toda situação desumana e de exploração que a sociedade vivia, e ainda vive, surgem expectativas para uma renovação e esperança social. Uma esperança social que se reflete no bem viver, no respeito e na dignidade. Dentro dos setores populares, tais como, operários e camponeses, encontram-se grandes valores humanos e evangélicos como abertura para a dimensão social, facilidade para a comunidade, ajuda fraterna, etc ${ }^{642}$.

É numa perspectiva de fé que o cristão pode testemunhar e participar na libertação dos povos oprimidos e das classes sociais exploradas, percebendo a incompatibilidade radical dos princípios evangélicos com uma sociedade injusta e alienante. Surge um sentimento de que não podem ser cristãos sem assumir um

${ }^{641}$ ANDRZEJ DAŃCZAK, La questione dello stato intermédio nella teologia cattolica negli anni 1962-1999, Pelplin: Wydawnictwo, Bernardinum", 2008, p. 175-176

${ }^{642}$ MUÑOZ, R., Nueva conciencia de la Iglesia en América Latina, Salamanca: Ediciones Sígueme, 1974, p. 292-293. 
compromisso libertador ${ }^{643}$.

A teologia, enquanto reflexão crítica, a luz da Palavra acolhida na fé, da práxis histórica e da presença dos cristãos no mundo poderá ajudar a perceber como estabelecer esta relação. A reflexão teológica ajudará a discernir os valores e a atitude do homem na sociedade, assim como explicar os valores de fé, de esperança e caridade. Tal reflexão teológica tem como justificativa dar apoio ao compromisso libertador, fazendo com que, a mensagem evangélica se torne mais autentica, mais concreta e eficaz ${ }^{644}$.

É claro que além de se comprometer contra a miséria, a injustiça, a exploração, o que se busca é a criação de um homem novo. O Vaticano II já dizia: "Somos assim testemunhas do nascer de um novo humanismo, no qual o homem se define antes de mais pela sua responsabilidade com relação aos seus irmãos e à história ${ }^{645}$ ". A aspiração pela criação de um homem novo é o desejo por uma sociedade melhor na América Latina.

Esta busca por uma sociedade mais digna é um desafio para a fé cristã, pois se busca uma conscientização por uma libertação social. Tem-se como objetivo a emancipação da sociedade e de todo o homem e por isso, a libertação das estruturas que alienam e oprimem se tornam importantes para que este processo se realize.

Portanto, é importante perceber o quando a fé, a esperança e caridade, com apoio de uma reflexão teológica, principalmente do artigo de fé da descida de Cristo a morada dos mortos, contribuem na libertação, pregação e solidariedade para criação de um novo homem. Se a sociedade estava alienada, oprimida e explorada é justo identificar-se em apoio àqueles que sofrem, levando a novidade de Cristo, possibilitando conduzir a humanidade para uma vida mais digna, de justiça e de respeito.

${ }^{643}$ Ibid., p. 215-217

${ }^{644}$ GONÇALVES, P. S. L., Liberationis Mysterium. O projeto sistemático da teologia da libertação. Um estudo teológico na perspectiva da regula fidei, 1997, p. 358, Tesi Gregoriana, Serie Teologia.

${ }^{645}$ Gaudium et Spes, 55 


\section{2 - A pregação aos mortos - O Evangelho como fermento para as mudanças sociais}

Se a afirmação da descida de Cristo à morada dos mortos tinha nos primórdios apenas o sentido da afirmação de sua morte, muito cedo, na reflexão patrística, ela ganharia novos acentos. Os Padres procuraram primeiramente explicitar seu sentido soteriológico e foi principalmente no âmbito da soteriologia que esta doutrina se desenvolveu, quer seja na Patrística, quer seja na reflexão teológica posterior. Mais tarde, foi dada também atenção à questão cristológica, procurando-se analisar o que a afirmação da descida à morada dos mortos significava para a compreensão do próprio mistério de Cristo.

A mais antiga interpretação soteriológica da descida de Cristo aos infernos parece ter sido a da - pregação aos mortos. Recorrendo principalmente a textos apócrifos (dada a escassez de textos das Escrituras), como Pseudo-Jeremias ${ }^{646}$, o Evangelho de Pedro ${ }^{647}$ e o pequeno ágrafo - "O Inferno disse a Perdição" - "Sua aparência nós não vimos, mas sua voz, nós a ouvimos ${ }^{648}$,", os padres afirmavam que o Senhor, após a morte, foi anunciar a salvação ou evangelizar os mortos.

Inspirado no anúncio e na pregação de Jesus aos mortos, podemos apresentar a necessidade de um anúncio que inspire uma transformação social. Anunciar o Evangelho, pregar a Boa-Nova como Cristo fez, requer uma transformação. É evidente a vontade de transformação e de desenvolvimento na sociedade latinoamericana. O Evangelho se torna uma expressão de conversão, da mesma forma como o Cristo desce a morada dos mortos para levar a oportunidade da conversão e acolhimento da Boa-Nova de Cristo.

Se converter no Cristo é se consentir por uma mudança de consciência que

${ }^{646}$ Trata-se de um texto apócrito atribuído ao profeta Jeremias, que aparece citado por Justino de Roma (que acusa os judeus de eliminarem essa passagem da Bíblia): “das palavras do profeta Jeremias também eliminaram esta passagem: 'O Senhor, o Deus Santo de Israel, lembrou-se de seus mortos, dos que dormiram na terra amontoada, e desceu até eles para anunciar-lhes a sua salvação" (Diálogo com Trifão 70). Também Irineu de Lyon considerava a passagem como bíblica (Adversus Haereses IV, 22, 1; III, 20, 4; IV, 33,1 e 33,12; V, 31,1).

${ }^{647}$ Quando Cristo é retirado do sepulcro por dois anjos gigantescos, seguido pela cruz, "ouviram uma voz vinda dos céus que dizia: 'Pregastes para os que dormem?' e da cruz fez-se ouvir uma resposta: 'Sim"” (ÉVANGILE DE PIERRE, 41-42, in: Évangiles Apocryphes, Paris: Seuil, 1983).

648 Clemente interpreta o texto, opondo-se à personificação dos Hades: "não é o lugar que recebendo uma voz disse as palavras que acabamos de citar, mas que aqueles cuja residência estava” CLEMENTE DE ALEXANDRIA, Les Stromates VI 45, 1, p. 151-3 
leva a ver a vida e as situações do cotidiano, pela ótica dos valores cristãos pregados pelo próprio Cristo. Em vista das profundas necessidades da sociedade tais como, uma mudança das mentalidades, de costumes e das estruturas, fizeram com que o Evangelho se tornasse fonte espiritual, em que se promovia a conversão do homem inteiro: espiritual, corporal, pessoal e social ${ }^{649}$. O Evangelho se tornaria o fermento para as mudanças sociais.

O Evangelho nos deve ensinar, em face das realidades em que vivemos imersos, que não se pode atualmente na $\mathrm{AL}$ amar de verdade o irmão nem portanto a Deus sem que o homem se comprometa em nível pessoal e, em muitos casos, até em nível estrutural com o serviço e promoção dos grupos humanos e dos estratos sociais mais pobres e humilhados, arcando com todas as consequiências que se seguem no plano destas realidades temporais ${ }^{650}$.

Para que pudesse atingir esta nova ordem social, era necessária a conscientização de novos valores ${ }^{651}$. Há de se perceber que as fontes evangélicas também manifestam valores que conduz a uma transformação social: dignidade pessoal, solidariedade, fraternidade, comunhão e libertação. Assim, evidencia-se uma unidade profunda entre a evangelização, conscientização e promoção humana. ${ }^{652}$.

Jesus se tornou aquele quem inspira a vontade do ser humano por mudanças estruturais e pessoais, sendo assim, o único libertador ${ }^{653}$. Somente Cristo seria aquele que libertaria do pecado pessoal e social. Por isso, o artigo de fé da descida de Cristo a mansão dos mortos, prefigura aquilo que o cristão poderia alcançar em sua prática cristã. "Descer" no sentido de atingir os maiores desafios do ser humano, humanizar-se perante o sofrimento e anunciar valores dos quais a conscientização e responsabilidade cristã em vista da dignidade e da justiça,

\footnotetext{
${ }^{649}$ Puebla, 1026
}

${ }^{650}$ Puebla, 327

${ }^{651} \mathrm{O}$ movimento moderno de libertação propunha-se uma finalidade política e social. Ele deveria pôr um fim à dominação do homem sobre o homem e promover a igualdade e a fraternidade de todos os homens. Que, nesse campo, tenham sido alcançados resultados positivos, é um fato inegável. A escravidão e a servidão legais foram abolidas. $\mathrm{O}$ direito de todos à cultura fez significativos progressos. Em numerosos países, a lei reconhece a igualdade entre homem e mulher, a participação de todos os cidadãos no exercício do poder político e os mesmos direitos para todos. O racismo é rejeitado como contrário ao direito e à justiça. A formulação dos direitos do homem significa uma consciência mais viva da dignidade de todos os homens. Comparando-se com os sistemas anteriores de dominação, as conquistas da liberdade e da igualdade, em numerosas sociedades, são inegáveis. Libertatis Conscientia, 8

${ }^{652}$ MUÑOZ, R., Nueva conciencia de la Iglesia en América Latina, 1974, p. 13-139

${ }^{653}$ GONÇALVES, P. S. L., Liberationis Mysterium. O projeto sistemático da teologia da libertação. Um estudo teológico na perspectiva da regula fidei, 1997, p. 131, Tesi Gregoriana, Serie Teologia. 
devem também fazer parte da própria vida cristã ${ }^{654}$. A experiência de fé faz pensar numa renovação social, em que é necessária uma profunda conversão das pessoas $^{655}$.

Temos iconografias que mostram que se Cristo desceu a morada dos mortos, Ele também pregou e levou a oportunidade da conversão e salvação de muitos. Para isso, requer mudança de atitude somada a uma convicção de fé. A vida cristã requer essa mudança de atitude e até mesmo de comportamento. É na sociedade, no próprio convívio que vemos a possibilidade em se identificar com o Cristo que pregou e levou a Boa-Nova, inclusive no pós-morte.

É fato que a sociedade vai-se alterando e são com estas alterações que o cristão deve perceber no como deve promover a Palavra de Deus. As mudanças podem ser perceptíveis e isso pode acontecer dentro da própria família, seja ela rural ou urbana. A mulher já começa a descobrir seus direitos, assim como o jovem busca pelos seus próprios valores dentro de um corpo social ${ }^{656}$. Se desperta valores como a fraternidade, solidariedade, e justiça ${ }^{657}$. É evidente uma resistência às formas de opressão e alienação impostas por uma força dominante. Os valores evangélicos se acentuam em contribuição ao nascimento de um compromisso com a libertação dos mais oprimidos ${ }^{658}$.

Não faltam esforços para um enriquecimento cultural. Uma nova linguagem surge na sociedade em vista de uma integração social. Ideias democráticas, reformas agrárias, movimentos populares surgem como forma progressiva de

${ }^{654}$ Ibid., p. 311

${ }^{655}$ MUÑOZ, R., op. cit, 1974, p. 137

656 Ibid., 1974, p. 43

657 MUÑOZ, R., Nueva conciencia de la Iglesia en América Latina, Salamanca: Ediciones Sígueme, 1974, p. 136

658 Ibid., 1974, p. 161; Na área das conquistas sociais e políticas, uma das ambigüidades fundamentais da afirmação da liberdade, no século das Luzes, está ligada à concepção do sujeito dessa liberdade como indivíduo que se basta a si mesmo e tendo com fim a satisfação de seu interesse próprio no gozo dos bens terrestres. A ideologia individualista inspirada por tal concepção do homem favoreceu, nos inícios da era industrial, a desigual repartição das riquezas, a um ponto tal que os trabalhadores viram-se excluídos do acesso aos bens essenciais, para cuja produção tinham contribuído e aos quais tinham direito. Daí nasceram pujantes movimentos de libertação da miséria mantida pela sociedade industrial.Cristãos - leigos e pastores - não deixaram de lutar por um reconhecimento equitativo dos legítimos direitos dos trabalhadores. Em favor dessa causa, o Magistério da Igreja elevou a sua voz, em diversas ocasiões. Libertatis Conscientia, 13 
redistribuição do poder social ${ }^{659}$.

Uma nova consciência se forma na busca de uma dignidade, responsabilidade e de uma vida mais humana. Já se há uma recusa de tratamentos de forma paternalista ou de simples instrumento de trabalho ${ }^{660}$. Surge o anseio por uma sociedade mais justa, consciente de seus direitos e empenhada na participação dos avanços científicos e tecnológicos ${ }^{661}$. A educação tem como função esta conscientização na sociedade ${ }^{662}$. Conscientizar quer dizer "tomar consciência pessoal ou coletiva de sua situação, de sua dignidade, de seus direitos e de suas responsabilidades" 663 .

Ainda que grande parte da população permanecesse alienada, há uma tendência de mudança principalmente por parte da juventude. A tomada de consciência, principalmente pela modernização dos meios de comunicação, fez com que se adquirisse um senso crítico $^{664}$ e consequentemente surgissem reinvindicações por condições melhores de vida como alimento, moradia, educação e saúde, tais reinvindicações se tornam uma prioridade, em vista daquilo que estavam sendo privados ${ }^{665}$. Dentro deste contexto, podemos inserir, por analogia, o artigo de fé da descida de Cristo à mansão dos mortos, em que Cristo desceu àqueles que morreram para pregar/anunciar, levando novamente a oportunidade da conversão. O anúncio cristão também deve levar esta mesma

\footnotetext{
${ }^{659}$ Ibid., 1974, p. 173-174

${ }^{660}$ Ibid. 1974, p. 176

661 A força libertadora do conhecimento científico concretiza-se nas grandes realizações tecnológicas. Quem dispõe das tecnologias, possui o poder sobre a terra e sobre os homens. Daí nascem formas de desigualdade, até então desconhecidas, entre os detentores do saber e aqueles que simplesmente utilizam a técnica. A nova potência tecnológica está ligada ao poder económico e leva à sua concentração. Dessa forma, no interior dos povos e entre os povos, formaram-se relações de dependência que, nos últimos vinte anos, deram ocasião a uma nova reivindicação de libertação. Como impedir que a potência tecnológica não se torne um poder de opressão de grupos humanos ou de povos inteiros?. Libertatis Conscientia, 12

662 De estas verdades fundamentales se dan conclusiones precisas que invitan a un determinado estilo de vida, a ofrecer a los estudiantes y a los miembros de las facultades oportunidades para crecer en su vida espiritual, moral y religiosa. Esta fe cree en el poder de la razón y demanda un empeño permanente en la investigación, la profundización y la extensión del saber humano. La fe no teme a la verdadera ciencia y la ciencia no deberia temer a la fe. Los seres humanos pueden volar alto solamente si usan ambas alas: la de la fe y la de la razón. En esta evaluación y examen de consciência, en relación al adjetivo católico, yo analizaria también muy cerca las relaciones que existen entre la Universidad, La Iglesia local, el obispo y la diócesis, el pároco y la parroquia y la Iglesia universal. PITTAU, GIUSEPPE, La Iglesia en el campo de la educación Evangelizar los centros educativos, in: Iglesia in América, Al encuentro de Jesucristo vivo, p. 209.

${ }^{663}$ MUÑOZ, R., Nueva conciencia de la Iglesia en América Latina, 1974, p. 176

${ }^{664}$ Puebla, 77.

${ }^{665}$ Medellín, Pastoral das Elites, 7. 21e; Movimento de Leigos, 10. 1 e 10. 2; Paz, 2. 7;
} 
oportunidade de transformação, que seja ela pessoal ou social. Descer até as classes mais baixas, conscientizar, dar dignidade a pessoa humana, se tornam ações cristãs, assim como, o próprio Cristo se compadeceu daqueles que se encontravam nas regiões inferiores.

\subsection{1 - O anúncio do Reino na promoção da responsabilidade} cristã.

Cristo, ao pregar a Boa-Nova, quer levar ao cristão a oportunidade de conscientizar e se responsabilizar pelas condutas cristãs. Ele, quis levar a vida onde havia a morte; renascer no Cristo é se deixar envolver pela Palavra de Deus. A Palavra de Deus começa a surgir em ambientes populares e pode se manifestar em valores importantes como solidariedade, fraternidade, caridade e até mesmo a liberdade. Valores estes que correspondem com a mensagem evangélica do anúncio do Reino promovido por Jesus e seus discípulos ${ }^{666}$. Aos poucos, a sociedade desperta para uma responsabilidade solidária, mesmo na dificuldade em conseguir seus próprios direitos como cidadão; é evidente um comprometimento em vista da generosidade e caridade ${ }^{667}$.

É dentro desse contexto que podemos mencionar, por analogia, a compreensão teológica de Pastor de Hermas, sobre a descida de Cristo à mansão dos mortos. A temática do Descensus para Pastor de Hermas chama atenção pela conversão. Ao perceber a mediocridade da vida dos cristãos, o autor acentua a pregação aos mortos por Cristo, dentro de uma perspectiva moral.

O Descensus apresentado por Pastor de Hermas teve uma grande difusão e relevância na Igreja nos finais do Séc. II. Era conhecida na Alexandria, Cartago, Roma e na Galácia, embora se discutisse se os textos de Pastor de Hermas foram considerados como canônicos. Sobre essa questão, foi muito discutida no Séc. II tendo partidários e retratores.

O Capítulo IX, do qual foi redigido o texto sobre o Descensus, parece ter

${ }^{666}$ MUÑOZ, R., op. cit., 1974, p. 209-210;

${ }^{667}$ MUÑOZ, R., Nueva conciencia de la Iglesia en América Latina, 1974, p. 211 
traços peculiares que se distingue do restante da obra do autor, isso faz com que surja a hipótese de que esta composição foi composta independentemente das demais. Torna-se possível que este texto tenha sido escrito na última fase redacional do livro, portanto seria fruto de uma reflexão madura do autor. O texto traz diversas imagens que apresenta a edificação da Igreja, assim como o destino dos homens que se desviam da verdade.

Neste contexto aparece o tema da salvação dada na morada dos mortos. Esta temática se apresenta dentro da edificação da Igreja, que se dá através da imagem da construção de uma torre que vai se levantando com pedras de todas as classes e procedências.

- Senhor, por que as quarenta pedras subiram do abismo com aquelas que já haviam recebido o Selo? Jesus disse: Porque os apóstolos e mestres que pregaram o Nome do Filho de Deus, tendo morrido no poder e na fé do Filho de Deus, pregaram também aos que já haviam morrido e deram o selo da pregação. Desceram com eles na água e subiram de novo. Mas estes desceram vivos e subiram vivos. Aqueles que já haviam morrido desceram mortos e subiram vivos. Graças a estes foram vivificados e reconheceram o nome do Filho de Deus ${ }^{668}$.

A primeira explicação da imagem da construção da Torre está, pois, dominada pela ideia da idoneidade ou não idoneidade das pedras, pela ideia das condições sob as quais estas pedras podem formar parte delas (moral). Isto marca a construção da torre dentro de um contexto teológico-moral.

O Descensus apresentado por Pastor de Hermas se compreende na missão de pregar e levar a todo o mundo, e isto se estende até a morada dos mortos, a importância da responsabilidade pela fé, o desejo de conversão, o consentimento aos valores cristãos dentro de uma perspectiva eclesial. Aqueles que carregam a fé no Filho de Deus recebem a missão de evangelizar e de levar a oportunidade de que uma mudança de vida se torna necessária.

Desta forma, o tema da pregação explica a presença de uma geração que carrega a fé no Filho de Deus, que como pedras, sobem dos abismos. Esta abordagem eclesiológica desperta a responsabilidade de levar a fé dentro de um contexto moral.

Esta atitude de responsabilidade, valores morais, somado a importância da ${ }^{668}$ PASTOR DE HERMAS, Le Pasteur, Comp IX, 15,4-16,6. 
evangelização e no anúncio da Palavra de Deus deve fazer parte da vida cristã, principalmente dentro do contexto latino-americano. Pastor de Hermas pode nos dar este exemplo de como a responsabilidade de fé e solidariedade pode se tornar uma atitude que começa a surgir em decorrência das dificuldades sociais, presente em vários setores da sociedade.

A busca pela dignidade faz com que nasça esse sentimento de partilha. Uma nova solidariedade latino-americana nasce despertando a vontade de transformação e desenvolvimento ${ }^{669}$. Surgem como fundamentais os valores de promoção humana, religiosa, de libertação de todo tipo de escravidão, de maturidade pessoal e de integração social ${ }^{670}$.

A Igreja faz parte destas novas aspirações da sociedade latino-americana. A Conferência de Medellín em 1968 é um exemplo claro da participação da Igreja dentro do contexto social. Os bispos começavam a se tornar membros integrantes de uma sociedade em que esta, tinha o desejo de mudanças e que começava a ter consciência de seus direitos. Da mesma forma, os sacerdotes e leigos também se comprometeram em apoio a uma sociedade mais justa e solidária.

Não obstante, apesar das reinvindicações por mudanças, ainda se constatava uma passividade da grande parte da população. O ensejo por mudanças, por organizações populares, permanecia apenas no nível de reinvindicações, pois estas muitas vezes estavam direcionadas a uma categoria e a uma solução para curto prazo. O sentimento de impotência e imaturidade às questões sociais fazia também com que muitas pessoas se rendessem a proteção paternalista, fugindo de perigos ou de qualquer esforço, a lutar por seus direitos e por uma vida mais digna. Tal atitude dificultava a integração e a ação social, facilitando o abuso da classe dominante ${ }^{671}$.

Em meados da segunda metade do século passado, na sociedade latinoamericana, houve uma conscientização da dignidade humana com seus direitos fundamentais. Com efeito, foi também surgindo entre os grupos cristãos à

${ }^{669}$ MUÑOZ, R., Nueva conciencia de la Iglesia en América Latina, 1974, p. 108

${ }^{670}$ Medellín, Movimentos de Leigos, 10. 2; MUÑOZ, R., Nueva conciencia de la Iglesia en América Latina, p. 292-293; SOBRINO, J., Jesus, o Libertador, I A história de Jesus de Nazare, 1996, p. 35, Série II, O Deus que liberta seu povo (Coleção Teologia e Libertação)

${ }^{671}$ MUÑOZ, R., op. cit. 1974, p. 77-79 
consciência de que a valorização da dignidade humana fazia correspondência com a dignidade do próprio Deus, criador e redentor da humanidade ${ }^{672}$. No documento de Puebla encontramos claramente o desejo da Igreja por uma sociedade mais justa e digna para com os oprimidos: "O amor de Deus que nos dignifica radicalmente se faz necessariamente comunhão de amor com os outros homens e participação fraterna; (...) deve tornar-se sobretudo obra de justiça para com todos

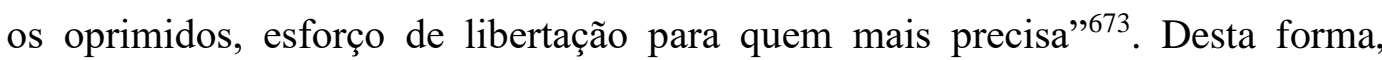
permitiu na sociedade ampliar uma valorização da dignidade da pessoa humana. $\mathrm{O}$ ser humano começou a ser visto como protagonista na história e centro do universo ${ }^{674}$. Houve uma superação da dicotomia entre corpo-espírito, permitindo redescobrir o valor do trabalho como realização pessoal e na construção de um mundo melhor ${ }^{675}$.

Portanto, os homens e mulheres criados a imagem e semelhança de Deus faziam crer que a dignidade e a justiça correspondiam à vontade divina ${ }^{676}$. A vontade de transformação na sociedade latino-americana era também justificada pelos sinais deste projeto criador de Deus. Por isso, quando Cristo desce a mansão dos mortos para levar a oportunidade da conversão, pela pregação do Evangelho, àqueles que morreram, vemos, por analogia, a necessidade do cristão em levar, assim como o Cristo, a oportunidade do conhecimento da Boa-Nova na vivência e na prática cristã. O cristão pode despertar pelo anúncio da Palavra a consciência da responsabilidade e dignidade cristã. O cristão deve "descer" para alcançar os limites do ser humano, e despertar o desejo pela transformação pessoal, social e até mesmo política, na qual a pessoa se insere, seguindo os passos de Jesus.

\footnotetext{
${ }^{672}$ Puebla, 306, 316, 319, 320

${ }^{673}$ Puebla, 327

${ }^{674}$ VELASCO, R. A., A Igreja de Jesus. Processo histórico de consciência social, 1996, p. 296

${ }^{675}$ MUÑOZ, R., Nueva conciencia de la Iglesia en América Latina, 1974, p. 283

${ }^{676}$ Es desde la fe en Cristo que la imagen del varón y la mujer, su identidad y realización histórica, concebidas por la antropologias y las demás ciencias humanas, encuentra los verdaderos criterios para una comprensión integral de los mismos, evitando el peligro siempre latente de una consideración reductiva, y por lo tanto empobrecedora o falsa del mismo ser humano. Sólo desde esta perspectiva es posible entender la creación del varón y la mujer y su misión específica en el designio amoroso de Dios, que quiso revelarse en la historia naciendo de mujer. Ambos reflejan en sí mismos con características propias la imagen y semejanza divina. Este es el fundamento de la igual dignidad, la diferencia y complementariedad natural del varón y la mujer que es 'llamada y tarea' a responsabilizarse en especifica vocación de cada uno, que adquiere una particular trascendencia en la colaboración a la obra creadora de Dios en el ejercicio 'de una paternidad y maternidad que también tienen en si mismas y de manera esencial y exclusiva una semejanza con Dios'. FANIZZI, N. C., La dignidad de la mujer y los desafios para la família Cristiana, in: Iglesia in América, Al encuentro de Jesucristo vivo, 2001, p. 253.
} 
O anúncio da Boa-Nova é pregado para um povo inserido na história. Com efeito, se Cristo, ao pregar a Boa-Nova na morada dos mortos, vemos, por analogia, que é na própria realidade humana que Cristo desce, anuncia e manifesta a Palavra que traz a esperança e a salvação que vem de Deus. Com este Deus inserido na história, podemos perceber as implicações práticas para vida cristã. A práxis eclesial deve corresponder com as ações de Cristo na oportunidade de levar a presença de Deus.

\subsection{2 - Deus se insere na história - A Missão profética da}

\section{Igreja}

A missão profética da Igreja ${ }^{677}$ tem como sujeito a própria ação salvífica de Deus na história ${ }^{678}$. A imagem da Igreja como Povo de Deus ${ }^{679}$, um povo reunido, quer designar também que o projeto salvífico de Deus se desenvolve no interior da história, por meio de um Povo escolhido, inserido numa sociedade e numa época histórica.

\footnotetext{
677 O termo "Igreja" tem sua referencia pela palavra grega ekklesía, em que pode ser traduzida na ideia de "convocação", proveniente do verbo chamar ( ek-kaléo), assim, significando a "assembleia dos chamados". Com o evento de Pentecostes, é formado o novo Povo de Deus pelos discípulos de Jesus, que guarda as características da reunião (ekklesía) e da eleição. O termo utilizado aos cristãos parece coincidir com a reunião do povo, mas também parece significar "...o apelo de Deus que convoca esta assembleia (cf. Ex 12,16; Lv 23,3; Nm 29,1). A Igreja, Povo de Deus (cf. Ap 2,10), é o Israel de Deus (Gl 6,16), convocado por Deus, chamado por ele (cf. 1Cor 1,2; Rm 1,7), MONLOUBOU, L., Igreja. In: MONLOUBOU,L; DU BUIT, F. M. Dicionário Bíblico Universal, 2003, p. 369; Igreja, portanto, parece fazer correspondência com o termo hebraico qahal (cf. Dt 4,10). Uma comunidade reunida, Israel é a convocação de Iahweh, comunidade de Deus, conhecido como povo eleito, GONÇALVES, P. S. L., Liberationis Mysterium. O projeto sistemático da teologia da libertação. Um estudo teológico na perspectiva da regula fidei, 1997, p. 224, Tesi Gregoriana, Serie Teologia.

${ }^{678}$ Ibid., 1997, p. 116-117, Tesi Gregoriana, Serie Teologia.

${ }^{679} \mathrm{O}$ 'povo de Deus' torna-se assim uma imagem fundamental da realidade da Igreja, abrindo-lhe uma perspectiva histórica e escatológica: este povo está em marcha na história rumo a um mundo novo. É, em primeiro lugar, um povo de batizados, incessantemente enviado e reunido para existir diante de Deus. DURAND, X., Povo. In: LACOSTE, JEAN-YVES, Dicionário Critico de Teologia, p. 1419; Cristo, ao iniciar a pregação do Reino, reúne consigo os discípulos, escolhe os doze, e os instrui dando-lhes condições para o seguimento e acesso aos mistérios do Reino. Nasce o Povo da Nova Aliança. Nesta perspectiva, a Igreja é identificada por este povo que se dispõe a seguir a Deus pela pessoa de Cristo, SOBRINO, J., Cristologia a partir da América Latina, 1983, p. 366-369.
} 
A nova noção de Igreja, como Povo de Deus, procurou buscar e descobrir qual seria o lugar da Igreja na história da salvação ${ }^{680}$. A Igreja aparece vinculada com o Povo de Deus da Antiga Aliança ${ }^{681}$ na busca pela unidade e comunhão a

Deus na história humana.

Compete ao homem a responsabilidade em manifestar o projeto de Deus para a humanidade. $\mathrm{O}$ homem se torna luz do mundo, fermento e sal da terra, na intenção em transformar a sociedade na família de Deus. Somente assim, pela proclamação da Boa-Nova, pelo empenho da unidade em Deus, e na promoção da esperança e salvação, podemos identificar o povo messiânico, que irá constituir a comunidade dos bem-aventurados na vida futura em Deus ${ }^{682}$.

${ }^{680}$ Pelo mistério da Paixão, Morte e Ressurreição de Jesus Cristo, nasce a Igreja pela ação do Espírito. O novo Povo de Deus formado pela comunidade dos discípulos de Jesus surge animado pela ação do Espírito. Se de princípio o grupo era pequeno: "naqueles dias, Pedro levantou-se no meio dos irmãos - o número das pessoas reunidas era de mais ou menos cento e vinte..." (At 1,15), a partir de Pentecostes (At 2), a comunidade dos discípulos de Jesus se amplia e se expande. A pregação apostólica permitiu a conversão de muitos que "ouvindo isto, eles sentiram o coração traspassado e perguntaram a Pedro e aos demais apóstolos: 'irmãos o que devemos fazer?' Respondeu-lhes Pedro: 'Arrependei-vos, e cada de vós seja batizado em nome de Jesus Cristo para remissão de vossos pecados. Então recebereis o dom do Espírito Santo" (At 2, 37-38). À unidade das primeiras comunidades revela-se "assídua ao ensinamento dos apóstolos, à comunhão fraterna, à fração do pão e às orações" (At 2, 42). A unidade pela fé e pela partilha se se torna a meta pela qual a multidão dos fiéis se empenham em realizar e promover ao redor dos mesmos pastores (At 4, 32-35). A força da unidade caracterizando uma comunidade como povo unido ao seguimento de Cristo é presente também nos textos paulinos quando se afirma: "Há um só Senhor, uma só fé, um só batismo" (Ef 4,5); "já que há um único pão, nós, embora muitos somos um só corpo, visto que participamos de um único pão" (1 Cor 10,17). Desta forma, o conceito de Povo de Deus se identifica com a Igreja do tempo presente com a Igreja nascente, chamada o novo Povo de Deus. Assim, o fiel manifesta sua fé nesta comunidade (At 2,41), Povo de Deus. Comunidade esta, assim denominada Igreja, representada por aqueles que chamados e reunidos em Cristo, continuam no seguimento e no compromisso a Deus.

${ }^{681} \mathrm{Na}$ relação da Igreja com Israel podemos perceber valores que se identificam tais como a ideia de eleição, que não é um privilégio, mas sim, um empenho a um comprometimento a Deus, a própria manifestação de Deus como Aliança e o cumprimento da Promessa que resulta numa tensão para o futuro. Israel é um povo. Tem a consciência de ter herdado a Promessa e a Aliança desde o Pai Abraão. Relembra a cada ano em ser considerado escolhido Deus, já na terra prometida, sua libertação e o cumprimento da promessa e da aliança do Sinai. A recordação da Aliança e Promessa é promovida em torno de grandes eventos de sua história e os ritos comemorativos são retrospectivamente introduzidos na narrativa do evento mesmo (Páscoa, Sinai, travessia do Jordão). É por isso que, o Antigo Testamento adotou, com quase plena exclusividade, o termo hebraico 'am, que significava laços familiares ou vínculo de sangue, para designar o povo eleito de Deus. Eis a força da descendência presente na no povo de Israel para que se perpetue a Aliança e a Promessa de Deus. O conceito de Povo de Deus, principalmente associado ao vínculo sanguíneo, apresenta elementos de solidariedade e comunhão fraterna, baseados na eleição divina como instrumento de sua ação na história da salvação. CONGAR, Y., A Igreja como Povo de Deus. Concilium. n.1, v.1, 1965, p.14; ANTÓN, A., La Iglesia de Cristo, 1977, p. 87 ${ }^{682}$ LG 9 
Se a Igreja, inserida na história, como Igreja Povo de Deus ${ }^{683}$, a ação do Cristo é nortear os passos do cristão para que na realidade do povo de Deus à ação evangelizadora seja eficaz ${ }^{684}$. Cristo ao descer à mansão dos mortos, leva pela pregação aos mortos, à oportunidade da conversão e da salvação. Tal atitude e exemplo deve despertar na vida cristã a mesma ação evangelizadora na realidade humana. Cristo atingiu o nível mais baixo da existência humana. A Igreja, a exemplo do Cristo, também pode atingir as periferias existenciais? levando a esperança e o encontro pessoal com o Cristo. O mistério da descida de Cristo ao "lugar dos mortos" revela-nos o amor de Deus por nós. Seu Filho não "só" desceu do céu à terra e assumiu nossa carne para viver a nossa vida, mas também morreu a nossa morte.

Quando falamos de um Deus inserido na história, falamos de um Deus escondido. É no Sábado Santo que percebemos com maior vigor esse escondimento de Deus que faz parte da espiritualidade do homem, de maneira existencial, quase inconsciente. A morte de Cristo, muitas vezes representa as trevas, a escuridão que interpela o cotidiano da vida. No entanto, com a morte do Filho de Deus podemos perceber um aspecto oposto, positivo, como forma de consolação e esperança, o sinal luminoso de uma esperança manifestado pelo Filho de Deus. Pela morte e ressurreição, vemos os sinais daquele que manifestou sua paixão pelos homens. É Deus que partilha não só o nosso morrer, mas também o permanecer na morte.

683 O termo laos que é usado, na tradução grega do Antigo Testamento, designando o Povo de Israel, também parece corresponder a uma unidade biológica, a saber, a descendência ou a consanguinidade por parte dos membros do povo de Israel. Os vocábulos 'am e goy que aparecem quase como sinônimos, vão se determinando e se especificando, de forma que 'am passa a ter uma referencia muito maior a Israel, enquanto Povo de Deus, e goy (goyim em sua forma plural), é aplicado, muitas vezes a outros povos, concretamente aos povos pagãos $(\mathrm{Nm} \mathrm{23,9)}$. A realidade teológica do povo eleito em sua relação com Deus, pode ser identificada pelas expressões 'amlaos, do texto hebraico e grego do AT. Isso se deve para designar o que de mais peculiar distingue o povo de Israel dos demais povos da terra. Israel é o povo eleito e congregado por Deus, não é simplesmente um povo entre tantos outros povos da terra, mas, dentre as diversas tribos nômades desprovidas de organização, foi constituído um único povo e nação. Um povo constituído por Deus, segundo a fórmula da aliança: "Estarei no meio de vós, serei o vosso Deu s e vós sereis o meu povo" (Lv 26,12; Ex 6,7) Israel foi eleito para que se pudesse manifestar a presença de Deus. Tornou-se o povo da promessa em que nele Deus se fez conhecer em toda a sua glória e poder. A ação salvífica de Deus se estende a partir de Israel para alcançar todo o mundo. ANTÓN, A., $L a$ Iglesia de Cristo, p. 88

${ }^{684}$ A Igreja Povo de Deus, "a Igreja dos Pobres na figura do povo crucificado que morre antes do tempo, como consequência da opressão sistêmica e de seu serviço profético ao Reino de Deus, realiza a sua vocação de ser fiel ao chamado do Senhor para a promoção da vida em abundância" GONÇALVES, P. S. L., Liberationis Mysterium. O projeto sistemático da teologia da libertação. Um estudo teológico na perspectiva da regula fidei, 1997, p. 228, Tesi Gregoriana, Serie Teologia. 
Afirmar que Cristo desceu à mansão dos mortos, significa que Deus feito homem, chegou ao ponto de entrar na solidão extrema e absoluta do homem, onde não se encontra o amor, reina o abandono sem palavra de conforto. Deus compartilhou conosco estes momentos existenciais para nos guiar e ensinar a superá-los. São sentimentos de abandono, medo, insegurança que fazem estarmos no escuro. Este Deus se insere na história da humanidade para levar nas trevas a luz que vem de Deus. O ser humano vive porque é amado e pode amar e, se no espaço da morte penetrou o amor, lá chegou à vida. Essa luz de Cristo que ilumina os lugares tenebrosos mostra o amor de Deus pelos homens de todos os tempos e lugares, assim como as nossas paixões, nossos sofrimentos, nossas dificuldades.

É a descida aos infernos que mostra o Jesus agoniado manifestando a sensação de estar abandonado por Deus. A exclamação de Jesus “Meu Deus meu Deus, por que me abandonaste" (Mc, 15,34) resume a aflição e a esperança de um povo escolhido por Deus, aparentemente tão abandonado. Tal exclamação, que parece manifestar a mais profunda escuridão sem Deus, nos faz perceber que o grito de Jesus na cruz remete-se a realidade do mundo inteiro.

A injustiça presente em nossa realidade latino-americana reflete este abandono e o descaso presente em nossa sociedade. Cristo pôde sentir a dor e a angustia de muitas pessoas, que esperavam um gesto de dignidade e de compaixão. A Igreja, ao seguir a mesma linha dos profetas de Israel, do Evangelho e da Tradição, tem o compromisso em denunciar toda forma de injustiça que se opõe ao plano de Deus. A Igreja tem o dever em denunciar a miséria que desumaniza como fruto da injustiça. Contribuir para a defesa e promoção dos direitos humanos, sobretudo os direitos dos pobres e oprimidos, fazendo-se assim a voz dos sem voz ${ }^{685}$.

Ao descer aos infernos, Deus ficou mudo, desceu a escuridão do silêncio. Esta sensação de vazio, de silêncio, de incompreensão, diz respeito muitas vezes às determinadas situações das quais o ser humano passa em sua vida em ter de se calar por um sistema opressor, injusto e desumano. Faz parte de uma postura cristã, pressionar os governos e as classes dirigentes na tentativa de eliminar toda injustiça e opressão. Solidária com os pobres, a Igreja deve protestar contra os

${ }^{685}$ Centesimus Annus, 22 
falsos valores da sociedade moderna, que destroem o que ainda resta de valores evangélicos tradicionais. Denunciar, enfim, o sistema iníquo, a violência institucionalizada das estruturas opressoras, as raízes materialistas do sistema capitalista, os interesses egoístas e todo uso do poder em proveito próprio ${ }^{686}$.

Esta atitude profética da Igreja deveria estimular indivíduos e povos a converterem-se do ódio e do egoísmo, do abuso do poder e da exploração, para o amor. Estimular os cidadãos a colaborar nos planos construtivos dos governos, e exercer também, uma crítica responsável em função do bem comum ${ }^{687}$.

No meio desse imenso povo pobre e sofredor presente em nossa sociedade, tem-se a intenção e o objetivo em fazer nascer pela força do Espírito, uma Igreja em que os pobres são, ao mesmo tempo, evangelizados e evangelizadores, destinatários e portadores, privilegiados da Boa-nova do Reino de Deus. O imenso povo messiânico se torna o lugar onde se realiza mais e mais o empenho eclesial pela esperança, justiça e misericórdia divina. O Reino de Deus se estende a todos os povos sem exceção ${ }^{688}$. Esta esperança não é uma esperança alienante, sem expectativa, mas uma busca constante na vivência do Evangelho e da dignidade humana. Mesmo em condições extremamente difíceis presente na sociedade, o acolhimento do Evangelho se torna a maior fonte de esperança para uma vida mais digna ${ }^{689}$.

A Boa-Nova não é somente anunciada, mas também celebrada. Ao celebrar jubilosamente a Boa-Nova no culto, e proclamar corajosamente a mensagem libertadora de Jesus, a esperança pela justiça e a dignidade renascem onde não se havia esperança ${ }^{690}$. "Evangelizadora como é, a Igreja começa por se evangelizar a

\footnotetext{
${ }^{686}$ MUÑOZ, R., op.cit., p. 210

${ }^{687}$ Medellín, Paz, n. 14b, 20, 22-23; Pastoral das elites, n. 21; Pobreza, n. 4-5, 10.

${ }^{688}$ Para analisar quem são os destinatários do Reino de Deus, constatamos que o Reino de Deus pertence unicamente aos pobres. De fato Jesus compreende sua missão como dirigida aos pobres: 'Fui enviado para anunciar a Boa-Nova aos pobres (Lc 4,18). Mostra isso também a resposta jubilosa de Jesus aos enviados de João: ‘A Boa-Nova é anunciada aos pobres' (Lc 7,22; Mt 11,5). Segundo Lc, a primeira bem-aventurança de Jesus proclama: 'Felizes os pobres, porque vosso é o reino de Deus $(\operatorname{Lc} 6,20)$. Estas afirmações são fundamentais para compreender o que é o reino de Deus para Jesus. SOBRINO, J., Jesus, o Libertador, I A história de Jesus de Nazare, 1996, p. 124, Série II, O Deus que liberta seu povo (Coleção Teologia e Libertação).

${ }^{689}$ GONÇALVES, P. S. L., Liberationis Mysterium. O projeto sistemático da teologia da libertação. Um estudo teológico na perspectiva da regula fidei, 1997, p. 311-312, Tesi Gregoriana, Serie Teologia.

${ }^{690}$ SOBRINO, J., Jesus, o Libertador, I A história de Jesus de Nazare, 1996, p. 30, Série II, O Deus que liberta seu povo (Coleção Teologia e Libertação).
} 
si mesma... Ela tem sempre necessidade de ser evangelizada, se quiser conservar frescura, alento e força para anunciar o Evangelho" (EN, 15). O anúncio evangélico na sociedade, na sua pobreza e simplicidade, generosidade e coragem evangélica, principalmente aos mais necessitados, constituem verdadeiramente o tempo da graça. Ao entrarmos em contato com os mais necessitados e desesperançados de nossa sociedade, na intenção em levar até eles a Boa-Nova da salvação, "nossas falsas seguranças e nossas ilusões se desfazem como neve ao sol; a existência gloriosa e bastante vã que nós construiremos, aparece-nos como retórica e falsa. Vê-se que não sabíamos nada: éramos vazios, nem sequer poderíamos passar por aprendizes ${ }^{691}$ ". A Igreja poderia tomar uma postura em não evangelizar os mais pobres de nossa sociedade, de forma a ser mais respeitada pela elite ou pela classe burguesa, obtendo prestígio, influência e estabelecer-se, no entanto, não corresponderia com a mensagem proferida por Jesus Cristo.

A sociedade, formada por cristãos conscientes e dinamizada pela esperança messiânica, tem como uma de suas funções carismáticas a promoção da unidade e da fraternidade. Teologicamente, os cristãos inseridos na sociedade formam a Igreja Povo de Deus e mesmo sendo esta Igreja santa e pecadora manifesta a presença salvífica de Deus.

Os mais pobres, inseridos na sociedade, apontam novos caminhos para a Igreja conduzindo-a a se aproximar melhor da mensagem evangélica. Jesus Cristo que se revela, apresentando a novidade radical da Boa-Nova, demonstra o seu amor pelos mais pobres, marginalizados e pecadores ${ }^{692}$. De acordo com as realidades das comunidades de interior e de periferias das cidades, as Igrejas

${ }^{691}$ CONGAR, Y., Balizas de uma reflexão sobre o mistério dos pobres, in: GAUTHIER, P., O Concílio e a Igreja dos pobres, 1967, p. 271.

${ }^{692} \mathrm{Em}$ muitas narrações Jesus aparece junto com os pecadores. Come com os publicanos (Mc 2,15-17b), fala com uma prostituta e até se deixa tocar por ela na casa de um fariseu (Lc 7,36-50), hospeda-se na casa do publicano Zaqueu (Lc 19,1-10), fala com a samaritana que tivera cinco maridos (Jo 4,7-42). Seja qual for a historicidade desses relatos, fica clara a atitude de Jesus de acolher os pecadores e não de se mostrar como juiz severo ou de querer destruí-los. E essa atitude fundamental de acolhida é magnificada nas parábolas. É preciso sair em busca do pecador para salvá-lo (Lc 15,4-10; Mt 18, 12-14), e na inigualável parábola do filho pródigo Jesus ensina qual o sentimento de Deus para com os pecadores (Lc 15,11-32). Jesus também os defende dos que acreditam serem justos e os desprezam (Lc 18, 9-14), e explicita sua missão como a de quem não veio para curar os sãos e sim os enfermos (Mt 9, 12; Lc 5,31). Por fim, faz a escandalosa afirmação de que os publicanos e as prostitutas entrarão no Reino de Deus antes que seus piedosos ouvintes no templo (Mt 21,31). SOBRINO, J., Jesus, o Libertador, I A história de Jesus de Nazare, 1996, p. 147-148, Série II, O Deus que liberta seu povo (Coleção Teologia e Libertação). 
locais são questionadas e convidadas a promover uma mudança de consciência em vista da dignidade humana.

O Concílio Vaticano II, em vista das mudanças históricas, procurava direcionar a Igreja para uma nova compreensão da realidade, para que se promovesse uma nova forma de relacionamento com mundo. Desta forma, podemos entender a mudança histórica iniciada pelo Concílio Vaticano II. "A mudança conciliar pressupõe novo paradigma de compreensão: uma concepção dinâmica, histórico-evolutiva, da realidade do mundo e, dentro dele, uma compreensão lúcida do caráter histórico do cristianismo e da Igreja, e da historicidade constitutiva de toda a Eclesiologia"693.

O próprio de João XXIII, em seu discurso de abertura do Concílio, acentuava a importância da atenção aos sinais dos tempos, do aggiornamento da Igreja, e da importância em saber aproximar as formulações dogmáticas, com a realidade histórica. Ao apresentar tais afirmações, estava adentrando em questões pouco discutidas consideradas intocáveis durante séculos: a "imutabilidade da fé e a imutabilidade da Igreja" $" 694$.

A Igreja, formada por um povo profético e messiânico, tem que seguir o caminho do Senhor; uma Igreja disposta ao serviço e não a exclusão, e dominação, uma Igreja dirigida pela graça de Deus e pela ação do Espírito aos pobres e pecadores; um serviço que nasce do amor e da caridade e que acima de tudo, é um serviço libertador. O amor solidário, que se estende no serviço aos pobres oprimidos, conduzirá infalivelmente a Igreja pelo caminho do seu Senhor.

Manifestar o amor por todos aqueles que foram desprezados, marginalizados e rejeitados revela-se o amor-ágape do Pai. Essa revelação do amor do Pai pela obra criada, tem que continuar na Igreja para que ela seja, na fidelidade a Deus e aos homens, cada vez mais transparentemente sacramento, isto é, "sinal" visível, veraz, eficaz, desse amor universal e salvífico de Deus pelos homens ${ }^{695}$.

É na descida aos infernos que vemos esse amor de Deus pela humanidade. O

${ }^{693}$ VELASCO, R. A., A Igreja de Jesus. Processo histórico de consciência social, 1996. p. 236 ${ }^{694}$ VELASCO, R. A., A Igreja de Jesus. Processo histórico de consciência social, 1996. p. 236 695 CONGAR, Y., Un pueblo messianico: la Iglesia, sacramento de la salvación . 1976, p. 14.16.77 
Filho perde de vista o Pai, de outro lado, o Pai neste momento, perde de vista o Filho. O evento do abandono de Deus na cruz como entrega do Filho, e a entrega do Filho como expressão do amor de Deus, revelam a tão grande dor do Pai e do Filho na morte de Jesus. O Pai que envia seu Filho através de todos os abismos e infernos do abandono, da solidão e da destruição, se faz presentes em todas as coisas, para que nada esteja isento do toque libertador de Deus ${ }^{696}$.

A Igreja demonstra com fatos aquilo que desde o começo do Cristianismo já nos tem apresentado: a força do Evangelho, o poder salvador de Deus e a misericórdia ${ }^{697}$ divina, manifestados na pobreza e fraqueza dos homens ${ }^{698}$. A Igreja se compadece da dor, da angustia, do sofrimento da mesma forma como Deus se compadeceu pela humanidade, entregando seu próprio Filho a morte e ao abandono nos infernos.

Em nossa sociedade, inclusive na América Latina, os cristãos ao descobrirem ou redescobrirem o Evangelho como a Boa-nova da justiça e da misericórdia de Deus, descobrem ou redescobrem a força da liberdade, da generosidade e a alegria da fraternidade cristã. É Deus que se compadece pela atitude cristã, manifestando a força da comunhão na fé, na esperança e no amor, que lhes dá coragem e perseverança contra todas as formas de opressão que humilham sua dignidade de filhos de Deus.

A concreta história de Deus na morte de Jesus e na sua descida à morada dos

${ }^{696}$ MOLTMANN, J., O caminho de Jesus, 1994, 243.

${ }^{697}$ A importância cristológica primária dos milagres é que mostram uma dimensão fundamental de Jesus: a misericórdia. Os milagres não mostram só o poder de Jesus, seja qual for sua capacidade de realizar curas, mas também, principalmente, sua reação à dor dos pobres e fracos. Repetidas vezes se diz nos sinóticos que Jesus sentiu compaixão e misericórdia diante da dor alheia, sobretudo das maiorias simples que o acompanhavam. "Viu uma grande multidão e, sentido compaixão, curou os enfermos' (Mt 14,14). Diz-se que sentiu compaixão de um leproso (Mc 1,41), de dois cegos (Mt 20,34), dos que não tinham o que comer (Mc 8,2; Mt 15, 32), dos que estavam como ovelhas sem pastor (Mc 6, 34; Mt 9,36), da viúva de Nain cujo filho acabava de morrer (Lc 7,13). E pelo menos em quatro narrações de milagres Jesus cura depois do pedido 'tem misericórdia de mim' (Mt 20,29-30p; 15,22p; 17,15; Lc 17,13). É esta misericórdia que, ao mesmo tempo, explica e se expressa nos milagres de Jesus, e que o define em aspectos bem fundamentais. Jesus aparece como quem se sente profundamente comovidopela dor alheia, reage diante dela salvificamente e faz dessa reação algo primeiro e último, critério de toda a sua prática. Na dor alheia, Jesus vê algo de último ao que só se pode reagir adequadamente com ultimidade. Lembrar isto continua sendo de suma importância para o trabalho eclesial hoje. SOBRINO, J., Jesus, o Libertador, I A história de Jesus de Nazare, 1996, p. 140-141, Série II, O Deus que liberta seu povo (Coleção Teologia e Libertação).

698 GONÇALVES, P. S. L., Liberationis Mysterium. O projeto sistemático da teologia da libertação. Um estudo teológico na perspectiva da regula fidei, 1997, p. 222-223, Tesi Gregoriana, Serie Teologia. 
mortos contém em si, todas as profundidades e abismos da história humana. Nesse sentido, a história humana, por mais que perpasse pelo sofrimento e pela dor, está assumida por este Deus inserido na história. Não há sofrimento nessa história que não seja convertido em sofrimento de Deus. Todas as dimensões da corporeidade humana, sejam de virtude ou de miséria, experimentam a vida de Deus.

Portanto, como anúncio evangélico a Igreja pode conduzir os homens e as mulheres a uma nova experiência de Deus. O Deus inserido no seio da humanidade deve despertar a práxis eclesial de que, mesmo no abandono, no sofrimento e na dor, podemos encontrar esperança de que a iniciativa de Deus não tardará. O Cristão, apoiado nos passos de Jesus, pode levar a presença e a luz de Deus onde os abismos e as trevas imperam. Com base nas virtudes apresentadas por Cristo, o povo de Deus pode ter meios para fazer com que a caridade e a solidariedade se tornem realidade ${ }^{699}$. O homem, como filho de Deus, foi libertado e resgatado por Cristo, o Messias, e a Igreja dá testemunho desta ação salvífica de Cristo. Assim, ao perceber Cristo como o Messias, que veio para evangelizar os pobres e estender a salvação a todos sem exclusão, a Igreja se torna a portadora e servidora da Boa-Nova de Cristo. A Igreja Povo de Deus se torna o povo messiânico no testemunho do amor e da caridade.

\footnotetext{
699 A Igreja é Povo de Deus quando tem características: a conscientização da prática da participação e comunhão em comunidade; a evangelização tendo como fonte o próprio Evangelho que reúne e organiza a práxis na comunidade e, por fim a própria Tradição que é o testemunho eficaz da práxis cristã. Assim sendo, a atividade cristã tem como natureza teológica o próprio Batismo e o corpo de Cristo como princípio histórico-social que permite uma participação ativa e viva da fraternidade evangélica, BOFF, L., O que significa teologicamente Povo de Deus e Igreja Popular. Concilium. v.6, n.196, 1984, p. 122
} 


\subsection{3 - A Palavra de Deus a serviço da libertação}

Cristo ao pregar a Boa-Nova tem como finalidade levar a plenitude do Reino de Deus no seio da humanidade, e assim, ele o fez na morada dos mortos, quando levou a Boa-Nova àqueles desprovidos da graça de Deus. É Cirilo de Alexandria que pode nos dar base para justificar uma pregação libertadora. Apoiado em Is 49,9, Cirilo interpreta que Cristo teria descido ao Hades e, após o anúncio da Palavra de Deus, liberta os que estavam na prisão e aponta para o alto ${ }^{700}$.

"Despoja toda a riqueza do diabo, dizendo: aos prisioneiros, saiam; aos que estavam nas trevas, venham à luz!” (Carta I 168-169, SCh 372, 185).

A pregação à morada dos mortos, apresentada por Cirilo, além de estar apoiada em Is 49,9 também tem sua relação com a passagem de 1 Pedro 3,19. Esta relação entre Isaías e 1 Pedro, podemos encontrar também no pensamento de Clemente de Alexandria (Stromates VI, 45,4), quando diz que a pregação aos espíritos é, pois, um mandato de Cristo dirigido aos mortos (presos nas trevas). A ação salvífica de Cristo faz com que os mortos sejam libertados e iluminados.

Desceu ao Hades, anunciou a Boa Nova aos espíritos que estavam alí, e aqueles que estavam lá embaixo, abriram as portas que estavam fechadas e saíram do abismo insaciável da morte. (Carta XI, 8, 89-90; SCh 392, p. 308)

Como se observa Cristo é apresentado não só como aquele que prega e liberta, senão também, como aquele que abre o caminho para a vida. A mensagem dirigida aos mortos foi o fim do cativeiro, a superação da morte, o caminho para a vida, uma clara mensagem de salvação. Uma salvação que se realiza em primeiro lugar em Cristo, se converte em caminho de vida para todos.

Pois tendo pregado aos espíritos no Hades e tendo dito a estes que estavam presos: Saiam! E a estes que estavam nas trevas: Mostram-se ao dia!; ao terceiro dia ressuscitou e abriu de novo em nossa natureza o caminho que leva aos céus,... (Carta II 8, 82-83; SCh 372, p. 232)

A Boa-Nova tem esta condição em libertar, resgatando o homem, aproximando-o de Deus. A libertação, promovida pelo anúncio da Palavra de Deus, tem como intenção conscientizar aos valores inseridos na humanidade. Desta forma, a Igreja, como sacramento de Cristo, atua hoje fundamentalmente na

${ }^{700}$ CIRILO DE ALEXANDRIA, Carta VI, 12,60ss, SCh 372, 396 
sociedade, isto significa que, para descobrir seu plano salvador promovido por Jesus, os cristãos devem estar atentos precisamente aos fatos e situações da vida e da sociedade, ao dinamismo da história dos povos ${ }^{701}$. Devem discernir os "sinais" dessa ação salvadora de Deus: nos valores culturais e religiosos dos povos, nas aspirações e esforços positivos do homem. São estes os "sinais dos tempos" que se deve reconhecer, numa atitude de discípulo, como um desafio à responsabilidade do cristão ${ }^{702}$. A ação responsável do cristão faz com que a evangelização tenha uma função conscientizadora, principalmente na sociedade latino-americana.

Os documentos eclesiais apontavam para a necessidade de olhar, a partir da fé, a vida e a história, particularmente frente à crise social vivida pelo continente latino-americano, na passagem da década de 1960 para 1970: a miséria, a tomada de consciência das maiorias e as estruturas coloniais vigentes ${ }^{703}$. Na Conferência de Puebla, a Igreja retoma o tema dos "sinais dos tempos", como uma das preocupações da "doutrina social da Igreja”, fundamentada na Sagrada Escritura, na doutrina dos Santos Padres e teólogos da Igreja e nos documentos do Magistério, e da promoção humana, respondendo assim, aos novos desafios que interpelam os cristãos latino-americanos ${ }^{704}$.

Os documentos insistiam que a transmissão do evangelho feita pela Igreja não poderia ser simplesmente uma repetição ou explicação da "mensagem" em suas formas bíblicas ou tradicionais, senão expressar esta mensagem em novas formas, enquadradas nas situações, na problemática, nas aspirações e nos esforços humanos, interpretando-o em função do plano de Deus ${ }^{705}$.

A ação evangelizadora deveria conduzir o homem a tomar consciência de

701 GONÇALVES, P. S. L., Liberationis Mysterium. O projeto sistemático da teologia da libertação. Um estudo teológico na perspectiva da regula fidei, 1997, p. 254, Tesi Gregoriana, Serie Teologia.

702 "Sinais dos tempos" quer expressar um reconhecimento pleno da historicidade do mundo e da própria Igreja. É o empenho em compreender que é o próprio tempo, com suas mudanças e seus acontecimentos decisivos, que proporcionam à Igreja os sinais da espera atual do Messias, sinais estes que em coerência com evangelho o homem espera pela plenitude do Reino SOBRINO, J., Jesus, o Libertador, I A história de Jesus de Nazare, 1996, p. 45, Série II, O Deus que liberta seu povo (Coleção Teologia e Libertação).

${ }^{703}$ GUTIÉRREZ, G., op.cit., p. 89-90

${ }^{704}$ Puebla, 472 e 473; Carta Enc. de João Paulo II, Sollicitudo Rei Socialis, 7 (1987). 137

705 LIBÂNIO, J. B., Concílio Vaticano II. Em busca de uma primeira compreensão, São Paulo, Edições Loyola, 2005.p. 77 
que a libertação integral é oferecida por Cristo na história e através história. Assim, toda a história estará aberta para a esperança da plenitude escatológica. O humano tem valor em si mesmo, mas há de ser libertado parcialmente na história presente com a esperança da libertação escatológica plena ${ }^{706}$. Os documentos latino-americanos buscavam, enfim, preferencialmente com a categoria "libertação", uma expressão atualizada e "conscientizadora" do evangelho de Jesus Cristo, encarnação do Deus libertador na história.

Ao perceber a as difíceis condições de vida do povo latino-americano, envolto a pobreza e miséria, a Conferência de Medellín convocou cristãos para se comprometerem na construção de uma sociedade mais justa e solidária, amenizando o sofrimento e angustias dos oprimidos. Com efeito, surge um clamor pela libertação que não lhes chega de nenhuma parte ${ }^{707}$. A iniciativa promovida por Medellín, e mais tarde por Puebla, continua repercutindo nas Conferencias Nacionais dos Bispos da América Latina, como podemos perceber o mesmo ensejo no discurso missionário do Documento de Aparecida.

Na tentativa em promover à libertação integral do ser humano, Medellín afirma que a Igreja tenha uma atitude autenticamente pobre, missionária, pascal, desligada de todo poder temporal e corajosamente comprometida com a libertação do homem todo, e de todos os homens ${ }^{708}$.

O objetivo de Medellín, para com os mais pobres, está no compromisso voluntário dos cristãos, no intuito de expressar a solidariedade para com os mais pobres e na denúncia da pobreza, resultado da injustiça e opressão. O próprio documento utiliza a imagem dos profetas, que já desde aquele tempo, denunciavam a pobreza como um pecado contra YHWH. O mesmo acontece com Jesus, quando este assume a condição de pobre para que todos tivessem vida e

\footnotetext{
${ }^{706}$ A historicidade, pois, da Eclesiologia está implicada na historicidade da Igreja, a qual deriva, por sua vez, da estrutura da encarnação da Igreja na economia da salvação e da missão recebida de dirigir-se à atuação vital de sua mensagem salvífica ao homem do momento histórico. Em cada época histórica, para chegar ao encontro salvífico com Deus, o homem dirige à Igreja perguntas novas e espera dela respostas também novas. Sendo a Igreja a presença sacramental da verdade e da graça salvadoras no mundo, ela deve abrir-se aos sinais dos tempos, sem trair sua origem e seu destino em Cristo, para que possa estabelecer o diálogo de salvação entre Deus e os homens. ANTÓN, A., El misterio de la Iglesia, p. 840

${ }^{707}$ Medellín, Pobreza da Igreja, 3

${ }^{708}$ Medellín, Pobreza da Igreja, 7
} 
vida em plenitude ${ }^{709}$. O testemunho da Igreja, para com os mais necessitados, já serve como uma forma de denúncia da pobreza e da necessidade em promover a solidariedade, reconhecendo os mais empobrecidos como irmãos e irmãs ${ }^{710}$.

Medellín e Puebla afirmam que em vista de tal situação, a Igreja incentiva à atividade missionária sempre redefinindo sua tarefa diante de uma situação que se apresenta contrária à vontade de Deus ${ }^{711}$. Perceber os sinais da fé é perceber este Deus conosco, que se insere no seio da humanidade. Inserir-se na realidade do povo oprimido é deixar-se levar pela realidade e carregar consigo a força da graça e a esperança que vem de Deus. Deus quer agir nos pequenos, e na minoria presente em nossa sociedade ${ }^{712}$.

É evidente que todo o testemunho conferido em seguimento à pessoa de Cristo tem como objetivo promover a dignidade humana. A dignidade humana é um dos temas chaves de Puebla e está intimamente ligada ao tema da libertação ${ }^{713}$. Tudo que atenta contra a dignidade da pessoa humana, é um atentado contra Deus e seu Plano de Salvação ${ }^{714}$. Diante de uma realidade opressora que, aniquila o valor e a dignidade de milhões de pessoas na América Latina, não é de se admirar que se tenha promovido uma reflexão teológica sobre a urgência de libertação. “A salvação, centro da Boa Nova, é libertação do que oprime o homem, mas, sobretudo libertação do pecado do maligno, na alegria de se conhecer a Deus e de ser conhecido por ele, de a pessoa o ver e de se entregar a $\mathrm{ele}^{715 \%}$

Libertação é a palavra-chave para compreendermos, justamente o que seja "salvação". A Salvação é o alívio de tudo o que oprime. Se a mensagem de Jesus é a Boa Nova em que diz: "O Espírito está sobre mim; escolheu-me para anunciar

\footnotetext{
${ }^{709}$ Medellín, Pobreza da Igreja, 7

${ }^{710}$ SOBRINO, J., Jesus, o Libertador, I A história de Jesus de Nazare, 1996, p. 37, Série II, O Deus que liberta seu povo (Coleção Teologia e Libertação).

${ }^{711}$ Ibid., 1996, p. 38, Série II, O Deus que liberta seu povo (Coleção Teologia e Libertação).

712 Puebla, 281: A situação de miséria, marginalidade, injustiça e corrupção que fere nosso Continente, exige do Povo de Deus e de cada cristão um autêntico heroísmo em seu compromisso evangelizador, a fim de poder superar semelhantes obstáculos. Diante de tal desafio, a Igreja sabe que é limitada e pequena, mas se sente animada pelo Espírito e protegida por Maria. Sua poderosa intercessão lhe permitirá superar as "estruturas do pecado" na vida pessoal e social e lhe obterá a verdadeira libertação", que vem de Cristo Jesus.

${ }^{713}$ Puebla, 188

${ }^{714}$ Puebla, 252

715 Puebla, 354
} 
a Boa Nova aos pobres, a libertação aos presos, dar vista aos cegos, por em liberdade os que são maltratados e anunciar o ano de salvação do Senhor" (Lc 4,18-19), a libertação conferida ao homem pode se estender tanto para os males físicos (doença) e morais (injustiça e exploração), quanto para a pobreza. ${ }^{716}$.

Assim, vemos que a libertação aponta para um crescimento e comunhão com Deus e os homens. Deus quer resgatar, libertar a humanidade de tudo aquilo que impede de ver a graça de Deus. Esta imagem da vitória de Cristo, que é capaz de libertar e conduzir para o alto, foi expressiva no artigo de fé da descida aos infernos, já desde o século II. No ícone da Anástasis, Cristo desce aos infernos com toda a sua glória, e resgata, e liberta os patriarcas da Antiga Aliança, puxando-os pelas mãos, é desta forma que Deus também toma sua iniciativa àqueles rejeitados e marginalizados, como se os tomassem pelas mãos, tirando-os de sua condição de miséria e abandono. A ação de Cristo deve despertar na vida cristã esta mesma atitude de libertação e de resgate, pois muitos esperam perceber nas ações humanas a presença de Deus.

716 TEPE, V., Estamos Salvos, 1982, p. 13 


\section{3 - Cristo desce a morada dos mortos como libertação e resgate de muitos. A Igreja na promoção da libertação dos mais pobres e oprimidos.}

No período patrístico foi comum à compreensão da descida de Cristo à morada dos mortos como - luta e vitória sobre os poderes infernais. Descendo aos infernos e aprisionando o Diabo e seus demônios, o Senhor libertou os justos que lá se encontravam. Fundamentada basicamente em apócrifos, como o Evangelho de Nicodemos ${ }^{717}$ e Odes de Salomão ${ }^{718}$, tal interpretação tornou-se célebre graças, principalmente, as homilias pascais, como as de Melitão de $\operatorname{Sardes}^{719}$.

A vitória de Cristo foi muitas vezes representada na iconografia. Os ícones das Igrejas orientais sobre a descida de Cristo à morada dos mortos, que começam a ser pintados no século VII, representam frequentemente o Ressuscitado tendo o demônio aos seus pés e com a cruz como instrumento de vitória sobre ele, sobre o pecado e sobre a morte, outros ícones representam o Ressuscitado segurando e puxando pelos pulsos Adão e Eva. O significado dessas representações é que a descida de Cristo ao lugar dos mortos e sua subida na ressurreição estão vinculadas. Na liturgia das Igrejas do Oriente a descida e subida são inseparáveis: "Vós ressuscitastes dos mortos depois de ter pisado a morte; vós subistes ao céu da glória”.

Porque veio para salvar a humanidade toda, Cristo tinha de ir ao encontro dos filhos de Deus, perdidos no lugar onde eles se encontravam. A Igreja como sacramento de Cristo, herda as mesmas práticas promovidas por Cristo. Se Cristo anunciou a Boa-Nova da Salvação, descendo a mansão dos mortos como resgate de muitos, compete também a Igreja o anúncio desta Boa-Nova, e o resgate daqueles que esperam em ver nela a iniciativa divina. Cristo saiu do lugar dos mortos, não sozinho, mas rodeado dos que foram libertados por ele.

717 Evangelho de Nicodemos, DESCIDA DE CRISTO AOS INFERNOS (Versão Grega), in: Apócrifos da Bíblia e pseudoepígrafos, São Paulo: Fonte, 2005, pp. 5,1-6,2).

${ }^{718}$ Odes de Salomão, Discese agli inferi, Magnano: Qiqajon, 2000, p. 42.

${ }^{719}$ Eu sou, diz o Cristo, eu sou quem destruiu a morte, quem venceu o inimigo, quem pisoteou o Hades, quem atou o forte, quem arrebatou para alto dos céus. (SARDES, Melitón de, Sur la Pâques 102, SCh 123, Paris: CERF, 1966. 
Libertar e resgatar se torna a missão da Igreja. O fiel, ao ser inserido na Igreja lhe é confiado à missão de anunciar a Boa-nova da libertação aos pobres e aos oprimidos, pois esta libertação também faz parte da mensagem central de Jesus, ou seja, anunciar o Reino de Deus aos pobres ${ }^{720}$.

A Igreja sempre procurou estar em defesa dos direitos do fraco, do pobre e do oprimido ${ }^{721}$. Não é de se surpreender que atualmente a Igreja opte por uma sociedade mais justa e fraterna, opondo-se ao sistema de opressão e exclusão.

\begin{abstract}
A Igreja deve seguir o exemplo de Cristo. Ela não pode excluir ninguém e deve oferecer a todos, grandes e pequenos, os meios de salvação que recebeu de Cristo. Mas sua opção e seus prediletos são os fracos e os oprimidos. Não pode ficar indiferente à espoliação do índio expulso de suas terras, à destruição de sua cultura. Não pode fechar os olhos ante a grave situação de insegurança em que vivem os pequenos, ante a fome dos pobres e a desnutrição das crianças. Não pode ignorar os desenraizados, os migrantes que buscam novas oportunidades, e que somente encontram abrigo debaixo dos viadutos ou se aninham nos arredores das grandes cidades. Cristo se faz presente e visível nestas pessoas. Maltratá-las é maltratar a Cristo $^{722}$.
\end{abstract}

Jesus, em seu ministério, proclamava a Boa-nova do Reino não somente com palavras, mas também com ações, que eram "sinais" da presença, da justiça e da misericórdia de Deus entre os homens. A Igreja deve ser também destes sinais do Reino. Na pregação de Jesus, o Reino não é anunciado como uma realidade distante e inatingível, mas como realidade que já se inicia e atua na história. A Igreja em sua fidelidade à missão, não pode limitar-se somente a uma proclamação, meramente verbal da Boa-nova do Reino aos pobres, e a denunciar o que está em contradição flagrante com ela. É necessário também, além do anúncio e da denúncia, realizar e promover gestos e fatos de libertação. Da mesma forma como Cristo, após a morte, leva a esperança da presença de Deus àqueles que morreram como resgate de muitos, a Igreja deve ser sinal de resgate,

\footnotetext{
${ }^{720}$ Em Jesus Cristo, este Deus revela de modo definitivo seu amor aos homens, em especial aos necessitados. A ação concreta de Jesus, sua vida e pregação são o testemunho disto. Jesus justifica suas atitudes frente aos marginalizados, apelando a misericórdia de Deus. Deus ama os pobres não por estes serem melhores que os outros homens, mas por se encontrarem em situações desprivilegiadas. Este amor de Deus desaia o homem, que não raras vezes se fecha em uma concepção de mérito e não consegue acompanhar este amor que transborda gratuitamente. ANDRADE, P. F. C. de. Opção pelos pobres: fidelidade à mais antiga tradição. Grande Sinal in: Revista de Espiritualidade, v.39, n.7, p.575-86, set. 1985.

${ }^{721} \mathrm{O}$ sinal [de sua origem divina] que a Igreja dará ao mundo não pode ser diferente do que Jesus mesmo deu, definindo-se como o enviado de Deus para levar a Boa-nova aos pobres. DUPONT, J., A Igreja e a Pobreza, Petrópolis, Vozes, 1965.p. 444; "Libertação é libertação do oprimido" BOFF, L., BOFF, C., Como fazer teologia da libertação, 2007, p. 45.

${ }^{722}$ Comunicação Pastoral ao Povo de Deus, 15
} 
esperança, presença de Deus no seio da humanidade.

\subsection{1 - O resgate e a libertação de muitos como opção preferencial pelos pobres.}

A vitória de Cristo presente no artigo de fé da descida de Cristo à morada dos mortos, diz respeito ao resgate, a libertação e até mesmo a iniciativa divina que rompe as prisões, permitindo que prevalecesse a salvação que vem de Deus. Quem muito desenvolveu a perspectiva da vitória no artigo de fé da descida de Cristo aos infernos, foi à teologia francesa. Os teólogos franceses acolheram a perspectiva da vitória de Cristo, na região dos mortos, já desenvolvida pelos padres da Igreja, e faz dela uma característica deste artigo de fé.

É Christian Duquoc que apresenta o artigo de fé do descensus como uma inserção tardia ao Símbolo, e que, originalmente queria apenas representar a realidade da morte de Jesus. Segundo este autor, foram os padres da Igreja que deram início a um desenvolvimento teológico daquilo que Jesus teria feito no pósmorte, ao empregar as diversas imagens de conquista, libertação e pregação na região dos mortos. Tais imagens significaram um processo de "remitização", processo que corre o risco de abafar com a capa do anedótico e do maravilhoso, o autêntico sentido da descida aos infernos ${ }^{723}$.

Duquoc afirma que com a descida aos infernos, vemos a atividade salvífica e vitoriosa de Cristo àqueles que morreram, mas, não nega o valor da linguagem mitológica ou simbólica para exprimir as realidades desta ordem. Ao admitir a inevitabilidade de seu uso pela Igreja antiga, afirmou à necessidade de uma nova demitização, um retorno da compreensão do Novo Testamento, fazendo desta descida um defrontar-se com o irremediável, com a morte, como destino trágico do homem. Assim, o descensus expressa a tragicidade da condição humana e a situa em relação a Deus e ao seu silêncio, enfrentado por Jesus após a morte ${ }^{724}$.

Dentro da compreensão de Duquoc nos faz refletir o quanto a tragicidade da

${ }^{723}$ DUQOC, C., La descente du Christ aux enfers, problématique théologique, Lumière et vie, n.87, 45-62, 1968.

${ }^{724}$ DUQUOC, C., Cristologia Ensaio Dogmático II, O Messias, 1980, p. 46-62. 
condição humana retrata, muitas vezes, a situação miserável do ser humano, que espera pela iniciativa divina. Os pobres de modo geral, os sem esperança, os invisíveis sociais pela opressão e injustiça, ouvem a Boa-nova do Reino como uma proclamação da libertação, fundada na justiça e na misericórdia divina, suscitando neles a fé e a esperança por um mundo melhor.

Dentro do contexto latino-americano, esta libertação e este resgate estão inseridos numa interpretação de fé, que busca responder as situações históricas, que desafiam e ao mesmo tempo abrem novos caminhos para a tarefa evangelizadora da Igreja. Por isso, a interpretação da fé é permanente, enquanto esforço de compreensão exigida pelo dom da fé, porquanto responde a interpelações concretas a um mundo cultural determinado. $\mathrm{O}$ mesmo pode dizer que o princípio da teologia da libertação, que nasceu de uma intensa preocupação pastoral, esteve ligado à vida da Igreja, a sua celebração comunitária, a sua inquietude evangelizadora e o seu compromisso com a sociedade latinoamericana, em particular com os mais pobres, excluídos e marginalizados.

Optar pelos mais pobres na sociedade latino-americana é promover este resgate e esta libertação, já promovida por Cristo, quando este desceu até à morada dos mortos e nos convida, não somente a refletir, mas sim a tomarmos também nossa iniciativa na busca de respostas e soluções aos desafios encontrados em nossa sociedade. A opção preferencial pelos pobres sempre esteve presente nas intenções da Igreja e vemos nos documentos eclesiais (Medellín, Puebla, Santo Domingo, Aparecida) e entre outros, o comprometimento e a responsabilidade de fé que deve estar presente na atitude do cristão.

O Deus, que conhecemos nos textos bíblicos, é um Deus presente na história. É um Deus Encarnado na história da humanidade, ao lado dos pobres, dos oprimidos, guiando sempre para a plenitude da vida e da liberdade para todos. Desde o Antigo Testamento percebemos que Deus se compadece pelos mais pobres e marginalizados. "O Deus que se manifeta no Antigo Testamento, coo Sem hor da história, criador, transcendente, e misericordioso, manifesta-se também como Deus da justiça, que se coloca ao lado do fraco, da viúva e do 
indigente ${ }^{725}$ ".

No entanto, não podemos esquecer que muitos membros da Igreja não se comprometeram e não deram importância as ações pastorais voltadas aos mais pobres e necessitados, vendo neles a imagem de Cristo. Mesmo assim, sempre houve, ao longo da história da Igreja, pessoas e acontecimentos eclesiais que testemunharam com coragem o empenho por uma sociedade mais justa e solidária. O resgate e a libertação de muitos se tornam a práxis eclesial aos mais necessitados. "A Igreja viveu, durante toda a Idade Média, ao menos em parte, ao lado dos pobres, dos marginalizados e soube, por muitos de seus filhos, manter um testemunho de pobreza, colocando-se a serviço dos mais necessitados ${ }^{726}$ ”.

O Documento de Aparecida, apresentado em 2007, faz parte deste testemunho eclesial por uma sociedade mais digna. $\mathrm{O}$ documento reafirma, com firmeza, a opção pelos mais pobres. O Papa Bento XVI, agora emérito, no seu discurso de inauguração, já afirmara: “A Igreja está convocada a ser 'advogada da justiça e defensora dos pobres ${ }^{727}$ ", A opção preferencial pelos pobres é uma das referências no documento de Aparecida. Em alguns parágrafos a explicitam com grande evidência: "Reconhecemos o dom da vitalidade da Igreja que peregrina na América Latina e no Caribe, sua opção pelos pobres...” (DA 128). Ainda: “A opção preferencial pelos pobres é uma das peculiaridades que marca a fisionomia da Igreja latino-americana e caribenha" (DA 391).

Os bispos também declararam veementes: "Comprometemo-nos a trabalhar para que a nossa Igreja latino-americana e caribenha continue sendo, com maior afinco, companheira de caminho de nossos irmãos mais pobres, inclusive até o martírio. Hoje nós queremos ratificar e potencializar a opção preferencial pelos pobres, feita nas Conferências anteriores" (DA 396). E insistem: “Assumindo com nova força essa opção pelos pobres, manifestamos que todo processo evangelizador envolve a promoção humana e a autentica libertação, sem a qual não é possível uma ordem justa na sociedade” (DA 399). Na mensagem final da

725 ANDRADE, P. F. C. de. Opção pelos pobres: fidelidade à mais antiga tradição. In: Grande Sinal Revista de Espiritualidade, v.39, n.7 , p.575-86, set. 1985.

${ }^{726}$ Ibid., v.39, n.7, p.575-86, set. 1985.

${ }^{727}$ Documento de Aparecida, número 395; de agora em diante o documento será citado com a abreviação: DA 
Conferência aparece de novo o compromisso: "Reafirmamos a nossa opção preferencial e evangélica pelos pobres" (ponto 4).

Aparecida faz lembrar um detalhe importante. Ao falar da urgência da renovação das paróquias, cita a existência de "pobrezas escondidas": "A paróquia não pode ser alheia aos grandes sofrimentos que a maioria de nossa gente vive e que com muita freqüência são pobrezas escondidas" (DA 176). Quais são essas pobrezas escondidas? Só mesmo uma profunda ‘amizade com os pobres' (DA 398) ajudará a descobri-las: são vexações sofridas, são indiferenças que marginalizam, invejas que desvalorizam, humilhações que massacram. São as exclusões, as faltas de ternura, de misericórdia, a pouca atenção às pessoas necessitadas, o abandono, o isolamento, a solidão forçada.

A Igreja na América Latina não pode ser entendida sem um compromisso preferencial pelos pobres. Se Cristo se fez sinal de esperança para os menos favorecidos, fazendo-os ter acesso ao Reino de Deus, a Igreja e todo o povo de Deus deve também ser sinal de esperança para quem não tem esperança. “A Igreja Latino-americana e a do Brasil, em particular, vem assumindo desde alguns anos uma opção de fundo, a que se costuma chamar de 'opção pelos pobres' ${ }^{728 "}$ ".

A partir do momento em que a Igreja se reconhece como via de acesso ao Reino, esta passa a estar a serviço do Reino de Deus, não perdendo de vista o sentido da provisoriedade, e aponta o sentido do infinito e definitivo no anúncio da vitória de Deus, sendo peregrina e solidária com toda a humanidade ${ }^{729}$.

\footnotetext{
${ }^{728}$ ANDRADE, P. F. C., op.cit., v.39, n.7 , p.575-86, set. 1985.

729 Jon Sobrino nos apresenta uma perspectiva sobre a vitória de Deus quando relaciona esta vitória com a expulsão do demônio. "O mal atuante não é pois, só uma ação isolada de demônios isolados,mas é algo que permeia tudo. É a força negativa da criação, que a destrói e a torna capaz de destruir, a qual se expressará histórica e socialmente como anti-reino. Jesus afirma também que o mal tem grande poder e sabe que diante dele os homens se sentem indefesos e impotentes. (...) Na América Latina não só existem calamidades inenarráveis, mas também o sentimento de indefesa e impotência. Os pobres se sentem indefesos e impotentes às vezes diante das doenças - $\mathrm{o}$ que lembraria as narrações evangélicas -, mas estão assim, sobretudo, diante das calamidades históricas, que não somente sofrem mas também lhe são mpostas em total impotência e desesperança. Deste ponto de vista e para expressar essa indefesa e impotência, propusemos a seguinte definição de pobres: Pobres são os que têm todos os poderes deste mundo contra si: oligarquias, governos, forças armadas, partidos políticos e, às vezes, Igrejas, instituições culturais. Cremos que o impacto mais profundo da teologia da libertação consiste precisamente em ajudar os pobres a superarem esse sentimento de indefesa e impotência, a crerem que é possível a libertação das forças opressoras" SOBRINO, J., Jesus, o Libertador, I A história de Jesus de Nazare, 1996, p. 145, Série II, O Deus que liberta seu povo (Coleção Teologia e Libertação)
} 
O compromisso eclesial deve se estender em toda a vida prática da Igreja, desde sua organização interna, lideranças e de presença no mundo. A opção preferencial pelos pobres deve corresponder a todo o agir pastoral, deve ser um critério essencial para o discernimento e conscientização. A missão da Igreja no mundo, com base nas ações de Cristo, deve se estender a todos os pobres e a toda a sociedade, de modo geral, para que com a graça de Cristo a salvação atinja a todos sem exclusão ${ }^{730}$. "Assumir a causa dos pobres é assumir, antes de mais nada, seus interesses mais imediatos. É colaborar na construção de uma sociedade conforme diz João Paulo II 'a distribuição injusta dos bens ceda o lugar a uma distribuição mais justa'. É fazer tudo para que o abismo entre os que têm e os que não têm "não aumente, mas diminua para que se tenha a igualdade social" ${ }^{731}$."

Não se pode negar uma aproximação entre a pessoa de Jesus e os mais pobres. O Papa Bento XVI em seu discurso inaugural afirmou: “A opção preferencial pelos pobres está implícita na fé cristológica naquele Deus que se fez pobre por nós, para enriquecer-nos com sua pobreza" (citando 2Cor 8,9). O Documento de Aparecida assume a expressão de Bento XVI quando afirma: "Essa opção nasce de nossa fé em Jesus Cristo, o Deus feito homem, que se fez nosso irmão" (DA 392, citando Hb 2,11-12). Desta forma, podemos concluir que a fé em Jesus é inseparável da opção pelos pobres. Não se pode aceitar Jesus sem ver nos mais pobres sua pessoa. No contexto latino-americano não se pode entender a pessoa e as virtudes de Jesus sem conversão eficaz dos mais necessitados. Os pobres ajudam a descobrir o verdadeiro rosto de Jesus Cristo e a mensagem do Evangelho. Para os cristãos, não se entende o resgate da dignidade dos pobres sem ter presente o estilo de vida de Jesus.

Faz parte do seguimento a Jesus o compromisso com os pobres: "Tudo o que tenha relação com Cristo tem relação com os pobres, e tudo o que está relacionado com os pobres clama por Jesus Cristo". O documento ainda reforça com as palavras de Jesus, que acentuam a opção pelos pobres: "Tudo quanto vocês fizeram a um destes meus irmãos menores, o fizeram a mim” (Mt 25,40) (DA 393). Jesus é o fundamento de toda a atividade cristã: "Tenham em vocês os

\footnotetext{
${ }^{730}$ GUTIÉRREZ, G., Uma teologia da libertação no contexto do terceiro milênio, in: O futuro da reflexão teológica na América Latina, 1998, p. 87.

${ }^{731}$ ANDRADE, P. F. C. de. Op.cit., v.39, n.7 , p.575-86, set. 1985.
} 
mesmos sentimentos que havia em Jesus" (F1 2,5). A compreensão de todo o agir dos discípulos e dos cristãos envolvidos dentro do contexto latino-americano deve ter como referencia a pessoa de Jesus. A conduta de Jesus, todas as suas ações e expressões devem orientar o estilo de vida dos cristãos. Eis a importância em conhecer a pessoa de Jesus presente nos Evangelhos ${ }^{732}$.

O cristão, ao se questionar qual seria a relação de Jesus com as pessoas, com as instituições da época, como eram organizadas as comunidades cristãs e qual seria o vínculo de Jesus para com estas, qual a postura, a prática, e os ensinamentos de Jesus para com os seus e principalmente, quais eram os objetivos mais importantes da sua missão e do anúncio da Boa-Nova, nos faz perceber que há um legado de ações promovido por Jesus que nos servem de testemunho. Ser cristão não é por simplesmente optar pelos pobres, mas sim por ter optado por Jesus, que se empenhou em favor dos pobres e se fez pobre entre os pobres. O cristão ao optar pelos pobres, não opta primeiramente por uma dimensão sociopolítica, mas sim evangélica. É a fé e o seguimento a Jesus que radicaliza a opção preferencial pelos pobres, opção que conduz eficazmente a um comprometimento sócio-político ${ }^{733}$.

*Em vista da realidade latino-americana, a opção pelos mais pobres e mais necessitados tem uma importância muito maior, que tende a ser indispensável para o discípulo e seguidor de Jesus de Nazaré, Senhor e Mestre. A expressão "preferencial" não quer dizer simplesmente uma opção. O Documento de Aparecida acentua: "Preferencial implica que deva atravessar todas as estruturas e as prioridades pastorais. A Igreja latino-americana é chamada a ser sacramento de amor, solidariedade e justiça entre nossos povos" (DA 396).

Muito se questiona em qual seria o ponto de partida para melhor atingir os mais necessitados, ou seja, é necessário partir dos pobres para alcançar a Cristo ou devemos partir de Cristo para alcançar os pobres? É seguro partir da pessoa e da prática de Jesus colhendo de suas ações princípios que possam determinar a prática cristã. Conhecer a pessoa de Jesus e perceber como as primeiras comunidades acolheram e transmitiram a pessoa de Jesus, pode contribuir para os

732 GUTIÉRREZ, G., Uma teologia da libertação no contexto do terceiro milênio, in: O futuro da reflexão teológica na América Latina, 1998, p. 88.

${ }^{733}$ Ibid., 1998, p. 90. 
diversos desafios presente na sociedade latino-americana ${ }^{734}$.

É necessário saber como foi à relação de Jesus para com os mais pobres e marginalizados, e seguir os seus passos para a edificação de nossa própria sociedade. "Concretizar o amor ao próximo é para Jesus aproximar-se do necessitado, é exercer a misericórdia para com o outro. A concretixação do amor ao próximo como amor ao necessitado é para Jesus a atualização da misericórdia de Deus"735.

Ao perceber as ações de Jesus e sua missão para com os menos favorecidos, vemos que a sua opção para com os mais pobres tem um sentido de denúncia. Jesus, ao se fazer pobre entre os pobres, se empenhou em mostrar que as pobrezas injustas não correspondem com o Reino de Deus.

Assim, a vida cristã tem todo o seu compromisso norteado pelas condutas de Jesus. Se somos a imagem e semelhança de Cristo, esta imagem e semelhança é também conferida aos mais pobres e desfavorecidos. E se Cristo pregou a uma justiça que vem de Deus, torna-se necessário à conscientização de que a todos confere a plenitude da vida, que já se expressa pela caridade e solidariedade, mesmo que esperemos pelo retorno do Senhor, em que todos os justos de Deus gozarão da felicidade eterna. “Aqui está a raíz última da justificativa do privilégio dos pobres: Assim é a bondade de Deus. Deus que ama a todos se compadece da situação dos marginalizados. Ouve os gritos dos marginalizados"736.

\footnotetext{
${ }^{734}$ GUTIÉRREZ, G., Uma teologia da libertação no contexto do terceiro milênio, in: O futuro da reflexão teológica na América Latina, 1998, p. 92.

${ }^{735}$ ANDRADE, P. F. C. de. A opção pelos pobres e a graça de Deus. In: Grande Sinal, revista de espiritualidade, v.38, n.9, p.656-67, nov. 1984.

${ }^{736}$ Ibid., v.38, n.9 , p.656-67, nov. 1984.
} 


\subsection{2 - A Boa-Nova liberta denunciando as causas da miséria e opressão.}

O teólogo francês, Louis Lochet, traz uma reflexão sobre a transformação que leva a libertação e a sensibilidade coletiva no mundo atual. Não é só o mundo que nos rodeia que mudou, mas também nossa sensibilidade e nosso pensamento, nossas relações com o mundo, com os outros, e até mesmo nossa própria concepção de homem. Com a mudança da nossa realidade altera-se também nossa linguagem. A progressiva descoberta da totalidade do mundo, as comunicações sociais que nos permitem conhecer a voz e os rostos dos homens de todos os países, gerou pouco a pouco um profundo sentimento de solidariedade humana ${ }^{737}$.

A obra de Louis Lochet Jésus descendu aux enfers ${ }^{738}$ é na verdade, um estudo soteriológico que trata principalmente da questão da eternidade (interminabilidade) do inferno. É nessa perspectiva que ele trata o tema da descida de Jesus aos infernos.

Parece-nos, com efeito, que a descida aos infernos, afirmada pela Igreja o Credo e revelada pela Escritura, não é somente uma espécie de episódio estranho e um tanto mítico da missão de Jesus: passagem sem consequências para a nossa vida presente e para nossa esperança cristã ${ }^{739}$.

Afirma que a descida de Cristo aos infernos deve ser vista como "uma dimensão da missão de Cristo e um aspecto sempre atual do mistério da salvação ${ }^{740 \%}$. Entende ele, a descida aos infernos, como a expressão de solidariedade e de libertação dos cativos, "não só dos vivos, mas também dos mortos; não só os de seu tempo, mas os de todos os tempos; não só dos justos, mas os dos réprobos ${ }^{741}$ ", concluindo com a possibilidade da salvação inclusive destes.

Jesus não se apresenta como aquele que condena, senão como aquele que salva, que liberta. Esta é a grande perspectiva que se estende a tudo, e que a tudo se permite ser iluminado, pois o que nos foi revelado não é somente que Jesus é o

\footnotetext{
${ }^{737}$ LOCHET, LOUIS, Jésus descendu aux enfers, 1979, p. 23.

738 Ibid., 1979, p. 20

${ }^{739}$ Ibid., 1979, p. 15

${ }^{740}$ Ibid., 1979, p. 16-17

${ }^{741}$ Ibid., 1979, p. 91
} 
Salvador, mas sim, que Jesus é o Salvador de $\operatorname{todos}^{742}$. A atitude cristã deve corresponder com esta atitude do Cristo, de levar a esperança e a oportunidade da salvação àqueles que se encontram nas trevas. Assim, como os mortos moravam todos juntos em uma espécie de vida diminuída, sem força e sem atividade (refains), o povo de Deus, sofrido, marginalizado, e pobre, espera por uma práxis cristã que possa levar o amor e a solidariedade que vem de Deus.

Em nossa realidade latino-americana muitos esperam por uma iniciativa, um gesto de dignidade e valores dos quais muitos possam ter a oportunidade de crescerem enquanto pessoa, inserida numa sociedade mais justa e fraterna. O Cristo que desce à morada dos mortos, levando a libertação dos cativos, deve ser o gesto da Igreja que leva a atitude de Cristo aos mais pobres e oprimidos. É evidente que não nos faltam expressões de Jesus em que se opõem as instituições, pessoas, e aos mecanismos estruturais que exploravam, oprimiam e marginalizavam os pobres: "Ai de vocês, os ricos... Ai de vocês que agora têm fartura..." (Lc 6,24-25). Ainda: "Louco! Nesta mesma noite você vai ter que devolver sua vida. As coisas que você acumulou, para quem vão ficar?” (Lc 12,20). Jesus derrubou a estrutura iníqua do Templo quando afirmou: "Tirem isso daqui! Não transformem a casa de meu Pai num mercado" (Jo 2,16). Jesus também soube denunciar a injustiça promovida pelo Império Romano, que havia feito do povo uma mercadoria; soube reivindicar a dignidade das pessoas, feitas a semelhança de Deus: "Dêem a César o que é de César, e a Deus o que é de Deus" (Lc 20,25). O próprio Santo Agostinho, que viveu no quarto século depois de Jesus, bem conhecia a estrutura do Império Romano, chegando a afirmá-la como "uma grande empresa de roubo" (em latim: magnum latrocinium) ${ }^{743}$.

As ações de Jesus recuperam e atualizam a coragem e a verdade dos profetas de Deus do Antigo Testamento. Os profetas, impulsionados pelo Ruah, o Espírito de Deus, souberam denunciar as injustiças que o povo de Israel sofria. Da mesma forma, Jesus tomado por um grande amor às pessoas, procurou demonstrar que o verdadeiro sentido da vida só é possível ao romper com todo o tipo de mal que oprime e explora.

\footnotetext{
742 Ibid., 1979, p. 42

743 (Mans 1962:95; De Civitate Dei IV.4)
} 
O cristão não pode ser um discípulo e missionário de Jesus e compactuar, ao mesmo tempo, com a corrupção, a exploração, a opressão. Assim, os bispos reunidos em Aparecida, diante dos desafios da globalização, propuseram: Sentimos forte chamado para promover uma globalização diferente, que esteja marcada pela solidariedade, pela justiça e pelo respeito aos direitos humanos, fazendo da América Latina e do Caribe não só o Continente da esperança, mas também o Continente do amor" (DA 64). E, por fim, afirmaram também, que: "De nossa fé em Cristo nasce também a solidariedade. Ela há de se manifestar em opções e gestos visíveis, principalmente na defesa da vida e dos direitos dos mais vulneráveis e excluídos, e no permanente acompanhamento em seus esforços por serem sujeitos de mudança e de transformação de sua situação. (DA 394).

Se até então vimos à importância da Igreja como Povo de Deus, inserido na história humana, abrindo-se a uma práxis cristã no anúncio da Boa-Nova, dentro de um contexto latino-americano, este anúncio adquire novas entonações de acordo com a realidade da América Latina. Desta maneira, a expressão "Igreja dos pobres" foi a fórmula encontrada na reunião de Puebla, para enfatizar qual seria o papel do cristão de acordo com os desafios presentes na sociedade.

Segundo José Comblin “a expressão 'Igreja dos pobres' fora lançada por João XXIII, mas não prosperou no contexto do Concílio. Acabou sendo retomada na AL destacando-se como centro da eclesiologia. A Igreja dos pobres diz o que há no povo de Deus, mas acrescenta algo fundamental: esse povo é o povo dos pobres. O verdadeiro povo de Deus é o povo dos pobres ${ }^{744}$ ”. Para Jon Sobrino, “a ótica do povo de Deus revaloriza o caráter histórico da peregrinação terrestre da Igreja, a igualdade fundamental de todos os cristãos, o reconhecimento do valor de toda a criatura humana, a revalorização das Igrejas locais" e contém indícios de prioridade aos pobres. Com efeito, a Igreja dos pobres não poderia ser simplesmente uma parte da Igreja, ao contrário, ela está inserida na totalidade da Igreja e dos seus membros $^{745}$. A Igreja deve levar aos mais pobres e necessitados a importância do evento salvífico promovido por Cristo. Seguindo esta reflexão eclesiológica, percebemos que "atender aos mais necessitados tem seu

\footnotetext{
${ }^{744}$ COMBLIN, J., O povo de Deus, 2002, p. 98

745 SOBRINO, J. Resurrección de la verdadera Iglesia. Los pobres, lugar teológico de la eclesiología, 1981, p. 99-142
} 
fundamento na teologia do Pai, do Filho e do Espírito Santo. O Pai tornou-se pobre ao conceder plena liberdade e autonomia às criaturas. O Filho identificou-se com os pobres sendo ele mesmo pobre e despojado até à crucifixão. O Espírito Santo dirige-se aos pobres" ${ }^{\prime 746}$.

O reconhecimento da Igreja dos pobres leva necessariamente à conscientização e as mudanças nas relações de poder. Uma Igreja seguidora de Jesus Cristo, sustentada pela fé e solidariedade do povo, anuncia um sentido de justiça presente nas expressões de Jesus. Assim sendo, edifica-se uma sociedade em que a fraternidade tem como base os valores pregados pelo próprio Cristo $^{747}$.

O povo na América Latina é ao mesmo tempo "Povo de Deus" e "Povo dos Pobres". Os pobres, sendo a maior parte da população oprimida, aspiram por uma libertação. "A Igreja é o povo dos oprimidos que encontram em Jesus Cristo a esperança de serem libertados de todo tipo de dominação e opressão para o resgate de sua dignidade como seres humanos ${ }^{748}$,

Portanto, a noção de Igreja Povo de Deus presente na história já despertada no Vaticano II, tem em Medellín e em Puebla uma imagem de Igreja que se faz mais fraterna e solidária aos mais pobres. "A Igreja dos pobres subsiste, (...) está presente. A história mostra que a Igreja não pode ser do povo se não é Igreja dos pobres"749.

Foi na Conferência de Puebla que os bispos latino-americanos perceberam que "do coração dos vários países que formam a AL está subindo ao céu um clamor cada vez mais impressionante. É o grito de um povo que sofre e reclama por justiça, liberdade e respeito aos direitos fundamentais dos homens e dos povos

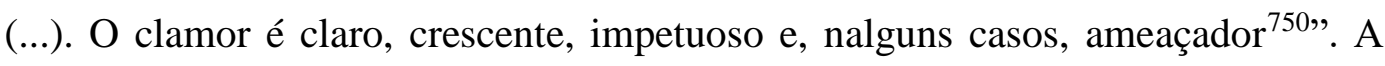
Igreja sempre buscou promover uma evangelização a todos os povos e nações,

${ }^{746}$ COMBLIN, J., O povo de Deus, 2002, p. 100

747 GONÇALVES, P. S. L., Liberationis Mysterium. O projeto sistemático da teologia da libertação. Um estudo teológico na perspectiva da regula fidei, 1997, p. 239-240, Tesi Gregoriana, Serie Teologia; O papel da Igreja "versa, como tema central, o espaço extraordinariamente amplo daquilo que os filhos da Igreja têm em comum com todos os homens: a presença e a atuação no mundo, a construção duma fraternidade terrena na ânsia de verdadeira fraternidade" HÄRING, B. Vistas e perspectivas novas que a Constituição abre para o futuro. In: BARAÚNA, G. A Igreja no mundo de hoje. 1967, p. 626

${ }^{748}$ COMBLIN, J., O povo de Deus, 2002, p. 279

${ }^{749}$ COMBLIN, J., O povo de Deus, 2002, p. 280

${ }^{750}$ Puebla, n. 87, 89 
assim como o empenho a caridade sempre esteve nas intenções da Igreja.

\subsection{3 - O compromisso eclesial - Uma Igreja que promove a salvação e a libertação aos pobres.}

O desígnio salvífico de Deus, revelado e manifestado definitivamente pela pessoa de Jesus Cristo, continua concretizando-se historicamente como salvação e libertação, misericórdia e consolação para os pobres e infelizes em nossa sociedade. A experiência da liberdade e da comunhão, da esperança e da fé enraizadas no coração dos pobres, pela descoberta do Evangelho, são capazes de superar os obstáculos que antes apareciam como insuperáveis.

O Evangelho ilumina com nova luz os desafios presentes na sociedade, ao mesmo tempo em que é descoberto ou redescoberto como Boa-nova de libertação, ou seja, como criador de amizade e comunhão, de confiança e coragem, para enfrentar os problemas em comunidade. Ao conhecer a realidade com seus desafios, temos as devidas condições para promover as transformações necessárias na sociedade.

Para que estas transformações ocorram, é necessário encarar os desafios presentes na sociedade, como pobreza, indiferença, injustiça, ou até mesmo, encarar a morte de uma maneira diferente. Em países ocidentais economicamente mais avançados, a morte, por exemplo, é vista como realidade a ser desconsiderada. Consequentemente são usados meios para negá-la ou ocultá-la, e viver como se ela não existisse. Uma cultura que não tem a capacidade de olhar para a morte e encará-la é incapaz de compreender seu sentido e desta forma, perdeu também o sentido da vida.

É por isso que em nosso contexto sociocultural, o artigo de fé da descida de Cristo à mansão dos mortos contrapõe nossa cultura atual. Ao professar que Jesus Cristo desceu à mansão dos mortos e deter-se longamente na reflexão, daquilo que o artigo de fé tem a oferecer, produziria compreensões particularmente importantes para nós: o aprofundamento de nossa fé numa nova forma de compreender e acolher a morte como parte essencial do ser humano, e a libertação 
das novas e terríveis formas de escravidão, de que são vítimas tantos de nossos contemporâneos, que se recusam em aceitar a realidade da morte, e que buscam meios para negá-la ou ocultá-la. Na cultura da produção e do consumismo, do êxito e do exibicionismo, da beleza e do prazer, há muitos interesses para negar ou esconder a realidade da morte. Consequentemente, muitas pessoas são levadas a crer que podem viver neste mundo de beleza, bem-estar, fama, riqueza a que podem aspirar; são levadas a crer que esses bens podem ser comprados.

A proclamação do mistério pascal, isto é, a proclamação da fé, morte e ressurreição de Jesus e da nossa ressurreição, contrapõe nossa cultura atual porque desmascara todos esses enganos e mostra que não é pelo mesmo caminho da busca pelo dinheiro, beleza, consumo e o prazer, nem pelos artifícios inventados para negar ou ocultar a morte, que se alcança a felicidade. A libertação é a vida nova em Cristo, que se manifesta na realidade da sociedade. Os valores humanos promovidos por Cristo nos servem para edificar uma sociedade, em que a justiça e a paz predominam pela força do Evangelho.

Na medida em que a Igreja, povo messiânico e sacramento da salvação, realiza, movida pelo Espírito do Senhor, ações e sinais de justiça, de misericórdia, de amor para os que não têm o que comer, o que vestir, onde morar, para com todos os indigentes, oprimidos e infelizes, sejam eles seus membros pela fé e pelo batismo ou encontrem-se fora de suas fronteiras visíveis, edifica-se o Povo de Deus, o Povo escolhido para que se cumpra as promessas de Deus. “A motivação última da opção pelos pobres não está no ódio a ninguém, mas no amor ao necessitado, resposta a misericórdia de Deus ${ }^{751}$ "

Os cristãos pobres presentes em nossa sociedade vivem a fé e a esperança na vinda do Reino, esperando por superar as situações de dependência, de opressão e até de miséria em que se encontram. A Igreja tem o compromisso em manifestar eficazmente a presença do Reino entre os homens quando o povo pobre, despojado e abandonado pode ser acolhido pelas comunidades cristãs. Os pobres inseridos nestas comunidades cristãs se conscientizam de que são eles os filhos do Reino, e filhos de Deus pelo batismo, essa é a natureza desse Reino: um Reino de

751 ANDRADE, P. F. C. de. Opção pelos pobres: fidelidade à mais antiga tradição. Grande Sinal in: Revista de Espiritualidade, v.39, n.7 , p.575-86, set. 1985. 
verdade e de justiça, de amor e de paz; quando esses pobres, acolhendo a Boanova, são ungidos pela fé, pela esperança e pelo amor, para realizar, no lugar em que se encontram, os gestos e ações concretas de justiça, de libertação, de salvação. acolhida, vivida e testemunhada a Boa-nova do Reino proclamada aos pobres.

A relação entre Reino de Deus e o pobre é um dos temas centrais da fé e da práxis cristã, também da reflexão teológica e da opção eclesial pelos necessitados. O Reino de Deus é um “já” que começou na história, dom gratuito de Deus em Jesus Cristo libertador, atualizado pela Igreja comprometida e solidária. É igualmente um "ainda não" que vem chegando, que coloca a esperança na parusia. Este Reino é uma unidade dialética de uma ação real, mas que só chegará à plenitude no porvir ${ }^{752}$.

A Igreja, presente nas comunidades, torna-se sinal deste Reino mediante o testemunho de solidariedade expresso na justiça, no amor, na reconciliação, na verdade e na paz. A Igreja também se faz sinal e instrumento de unidade e de comunhão com Deus, e entre as pessoas ${ }^{753}$. Uma Igreja que atualiza a ação salvadora e libertadora de Cristo, através da reconciliação e unificação dos homens em um povo.

Numa atitude solidária, a Igreja deverá estar presente na libertação e no desenvolvimento, na mudança estrutural e na construção de uma nova sociedade $^{754}$. A participação da Igreja, na transformação sócio-econômica, não se dá mediante instituições próprias, mas pela presença de cristãos nas instituições e grupos da sociedade comprometidos com os marginalizados, com os mais pobres. Assim, a Igreja cumpre sua tarefa de ser fermento na massa ${ }^{755}$, no anúncio da Boa-Nova.

${ }^{752}$ DUSSEL, E., op.cit., Vol. III, p. 683

${ }^{753}$ Medellín, Catequese n. 10; Pastoral popular, n. 13; Movimento de leigos n. 12; Pastoral de conjunto, n. 9,11

${ }^{754}$ Medellín, Mensagem, p. 28-29

${ }^{755} \mathrm{Ibid}$, Meios de Comunicação Social, n. 12 
O cristão é chamado a participar na vida social, econômica e política de seu país ou continente, agindo segundo os valores éticos evangélicos, a fim de promover um maior desenvolvimento e bem-estar geral, procurando assim o bem de todos. De outro, principalmente, em contexto de injustiça estrutural, é chamado a promover a mudança de tais estruturas buscando substituí-las por estruturas mais justas, tendo a consciência de que neste caso seu agir provoca uma mudança na realidade do mundo, de tal modo que, com o auxílio da Graça, o Reino de Deus se faz sacramentalmente mais presente e diminui a distância ainda que de modo frágil e reversível entre nossa realidade e o "novo céu e a nova terra" ${ }^{756}$.

No âmbito da missão solidária da Igreja, destaca-se: sua participação na construção de uma nova sociedade, como ministério de salvação; sua presença na libertação e na construção do mundo com a luz de Cristo; sua contribuição com uma visão global do homem e da sociedade, a partir do evangelho; sua preocupação com a libertação integral do ser humano: corpo e espírito, indivíduo e comunidade. É desta maneira que a Igreja dinamiza a utopia humana, mantendoa aberta à dimensão transcendental, libertando a política de messianismos e fanatismos $^{757}$.

Com a luz de Cristo, a Igreja contribui com um elemento novo para o desenvolvimento: a exigência de Deus e de seu evangelho, a esperança do Reino. Os cristãos deveriam ser fermento do evangelho no meio do povo, para comunicar através de seu testemunho a mística necessária às mudanças estruturais da sociedade, e desenvolvimento integral do ser humano, colocado no centro da história. Assim, a Igreja se torna inspiradora da consciência pessoal e coletiva ${ }^{758}$.

Assim, como sinal salvífico, a Igreja contribuirá com sua mensagem para uma tomada de consciência sobre a necessidade de diálogo entre os povos, e um indispensável espírito de solidariedade. Na América Latina, a Igreja pode servir de modelo e estímulo para a integração social. Os sinais salvíficos de Deus, revelados definitivamente em Jesus Cristo, continuam manifestando-se e concretizando-se historicamente como salvação e libertação, misericórdia e consolação para os pobres e infelizes.

Os cristãos pobres, presentes em nossa sociedade, vivem a fé e a esperança na vinda do Reino lutando, com os meios pobres, mas sempre eficazes do

\footnotetext{
${ }^{756}$ ANDRADE, P. F. C. de. A ação política como ação ética e escatológica, in: Grande Sinal, v. 47, n. 1 , p. $35-41,1993$.

${ }^{757}$ Ibid, Mensagem, p. 28-29

758 Ibid, Justiça, n. 5
} 
Evangelho, para superar as situações de dependência, de opressão e até de miséria em que se encontram. A Igreja manifesta eficazmente a presença do Reino entre os homens quando o povo pobre, despojado e abandonado nas comunidades, é acolhido na igreja como na sua própria casa; quando estes pobres presentes nas comunidades se conscientizam de que são filhos de Deus, o Reino se abre a eles, um Reino de verdade e de justiça, de amor e de paz. Quando esses pobres, ao acolher a Boa-nova, são urgidos pela fé, pela esperança e pelo amor, para realizar, no lugar em que se encontram, na sociedade, gestos e ações concretas de justiça, de libertação, de salvação.

O Evangelho, Boa-nova da libertação, foi usado não poucas vezes, ao longo da história da Igreja, contra a opressão aos mais pobres e necessitados. Desta forma, uma comunidade de pobres que se conscientiza pela luz do Evangelho, se expressa assim: "Ninguém nasceu para morrer. Precisamos sair de uma religião do medo para uma religião de salvação. De uma religião de opressão para uma religião de crescimento" 759 .

A novidade libertadora do Evangelho, que, quando é descoberto, cria naqueles que o acolhem uma nova consciência e novas atitudes, Campanhas de Saúde, Melhorias dos meios de Comunicação etc. “A libertação trazida por Cristo acontece onde o povo tem o direito de falar, julgar e agir" ${ }^{360}$.

A descoberta do Evangelho fez surgir nos pobres uma nova consciência, e particularmente uma nova consciência de ser Igreja e do que é a Igreja: uma Igreja onde todos têm os mesmos direitos fundamentais; uma Igreja povo de Deus, convocado por Deus sem discriminação nem acepção de pessoas: "Não é só o branco, nem preto, nem rico, não tem qualidade, é para todos que querem seguir o caminho de Deus... onde o pobre tem o direito do rico, o rico para ser da Igreja tem que ficar no mesmo nível do pobre"761.

759 Comunidades das paróquias de S. Domingos e Novo Brasil, in: SEDOC, Comunidades Eclesiais de Base: Uma Igreja que nasce do povo, Encontro de Vitória, Petrópolis, Vozes, v.7, n. 81, Maio 1975, col. 1068

${ }^{760}$ II Encontro sobre Comunidades de Base, in: SEDOC, Comunidades Eclesiais de Base: Uma Igreja que nasce do povo pelo Espírito de Deus. Relatórios vindos das bases, Petrópolis, Vozes, v. 9, n. 96, Novembro 1976, col. 460

${ }^{761}$ Relatório da Comunidade de Tacaimbó, in: SEDOC, Comunidades Eclesiais de Base: Uma Igreja que nasce do povo pelo Espírito de Deus, Petrópolis, Vozes, v. 9, n. 95, Maio 1976, col. 262 
Cabe Teologia a tarefa de auxiliar a reflexão da comunidade cristã, ajudando-a a julgar à luz da fé a realidade na qual os membros desta comunidade vivem para que se possam descobrir pistas para um correto agir no mundo. A Igreja LatinoAmericana nos últimos vinte anos tem desenvolvido uma longa caminhada ao longo da qual se tornaram claros alguns critérios fundamentais que devem presedir o agir cristão no mundo. Entre estes sem dúvida, o mais fundamental é o critério da 'opção preferencial dos pobres' assumido pelo Episcopado latio-americano em Puebla $\left(1979^{762}\right)$.

A Igreja não é mais vista como um povo em que tende a ficar mudo e passivo. Eis os sinais da presença do Reino: os que estavam mudos, agora falam, os que eram inválidos agora participam, os que se sentiam rejeitados, marginalizados e tristes, agora se sentem felizes, libertos.

Em vista das necessidades do povo e da sociedade, busca-se por uma luta contra a fome, a enfermidade e a falta de moradia, assim como todo tipo de humilhação que fere a dignidade humana. A Igreja da América Latina percebeu que uma forma de cumprir com os valores evangélicos, de acordo com as experiências das primeiras comunidades e aos "sinais dos tempos", é colocar-se ao lado dos mais necessitados e oprimidos, na promoção da caridade e fraternidade, assim como ensina a parábola do Bom Samaritano ${ }^{763}$.

Quando a Igreja se aproxima da realidade dos pobres acentua o caminho da solidariedade. Surgem iniciativas dentro do campo social, em que, vai se construindo uma nova experiência solidária, que se contrapõe as atitudes individualistas e consumistas das classes dominantes. A Igreja vai se estruturando e se edificando nas pequenas comunidades inseridas no meio dos pobres, e dando a elas uma nova forma de pensar, em vista dos valores evangélicos. Ao serem formadas por pessoas, que sofrem todo tipo de humilhação e opressão, estas comunidades socorrem aqueles que estão em situação de desespero por causa da fome, da falta de moradia, da falta de assistência à saúde, do desemprego ou da falta de oportunidades na escola.

O próprio Jesus demonstra seriedade ao sofrimento corporal, psíquico e social das multidões empobrecidas. As primeiras comunidades, em seguimento a

762 ANDRADE, P. F. C. de. A ação política como ação ética e escatológica, in: Grande Sinal, v. 47, n. 1 , p. 35-41, 1993.

${ }^{763}$ SOBRINO, J., Jesus, o Libertador, I A história de Jesus de Nazare, 1996, p. 47, Série II, O Deus que liberta seu povo (Coleção Teologia e Libertação). 
Jesus, procuram se compadecer do sofrimento humano e assim, somente com esta compaixão e com estes gestos de acolhida, a Igreja poderá tornar-se sinal do Reino de Deus, que se estende aos pobres e marginalizados da América Latina.

$\mathrm{Na}$ comunidade os laços de família, afeto, amizade e o companheirismo presentes na vida dos mais necessitados são celebrados e valorizados. A busca pelo sustento e a necessidade de pão, de teto e de saúde fortalece e enriquece os laços entre os pobres, sua capacidade de afeto e de acolhida fraterna. As comunidades cristãs passam a ter uma característica de em que a acolhida, a fraternidade e a solidariedade se tornam referência uma para a práxis cristã.

Numa sociedade em que muito já se desprezou os pobres e os marginalizados, as comunidades se constituem como um espaço onde cada um pode se sentir acolhido solidariamente a partir de sua dignidade. Numa sociedade onde a cultura individualista, veiculada e alimentada pelos meios de comunicação de massa, ameaça à vida e fere a dignidade humana, trazendo angústias, medo, insegurança e frustrações aos pobres, as comunidades cristãs subsistem como lugar de encontro e convivência, de apoio mútuo e de serviço aos mais necessitados. Estas não só estão a serviço dos necessitados, mas também os acolhem para viverem numa nova família de irmãos e irmãs, cuja principal característica é a solidariedade. Em um povo que, apesar de ameaçado pela tristeza e pela angústia da morte, ainda é capaz de festejar os sinais de vida, as comunidades cristãs se tornam um espaço de convivência alegre, onde as pessoas podem conversar, dialogar, rir, e, agradecidas, celebrar o Deus da vida que ressuscitou a um Crucificado, Jesus Cristo, arrancando-o da morada dos $\operatorname{mortos}^{764}$.

O amor mútuo e a reciprocidade são de fundamental importância para o

\footnotetext{
${ }^{764}$ MUÑOZ, R., Experiencia popular de Dios y de la Iglesia. In: V.V.A.A., Cambio social y pensamiento cristiano en América Latina, 1992, p. 167; Certamente, assim é Cristo crucificado, confessado como filho de Deus e salvador. Mais perto de nosso tema, em Isaías (Is 52, 13-53,12) apresenta, nos cânticos do servo de Javé uma figura misteriosa - real ou imaginária, indivíduo ou coletividade - destroçada pelos pecados do mundo e que traz a salvação. Este servo é, em primeiro lugar, homem de dores, acostumado ao sofrimento, levado à morte - pelo que os outros fazem sem defesa, sem justiça, depreciado, desprezado por todos. Em segundo lugar, não só não é considerado como possível salvador, mas exatamente ao contrário; é considerado como leproso, condenado, ferido por Deus e humilhado, e aparece, além disso, como pecador: deram-lhe sepultura com os malfeitores e foi contado entre os pecadores. SOBRINO, J., Fora dos pobres não há salvação, 2008, p. 22.
} 
testemunho solidário da comunidade, dos seguidores de Jesus. Todos devem ser tratados como iguais, todos são importantes, cada um responsável pelos demais e pelas tarefas comuns, segundo a originalidade e dons próprios de cada um. Os cristãos comprometidos com a justiça e a paz entendem que a pobreza e a injustiça são um mal presente na sociedade, que deve ser erradicado para que todos possam viver com dignidade. A dignidade humana é um bem inesgotável que deve ser reconhecido e alimentado pela pessoa de Jesus. Somente assim, as comunidades se tornam um espaço onde os pobres podem encontrar a esperança por uma vida melhor, apoiada pelos valores evangélicos.

Em contexto de injustiça generalizada e estrutural, o cristão é chamado a transformar tal realidade mediante a ação político-social e a decisão de participar ou não de tal ação possui implicações não só relativas à sua salvação individual (política como 'meio de salvação'), mas também à presença sacramental do Reino no mundo e a vitória ainda que parcial sobre as forças do mal, possuindo portanto relação escatológica-coletiva. A ação política, ao modificar as 'estruturas do mal' que produzem injustiça, dor e morte, apresenta uma contribuição à formação de uma nova situação social onde a presença do mal objetivo é mais débil, contribuindo assim para formar um habitat mais sadio ao cultivo de uma vida de santidade, reforçando a dimensão salvífica coletivo-individual desta luta ${ }^{765}$

Jesus Cristo é aquele que se coloca solidariamente do lado dos menos favorecidos e abandonados, pelo sistema injusto de seu tempo, curando os maltratados, libertando os oprimidos e levantando os caídos. Desta forma, os cristãos das comunidades descobrem na Bíblia o rosto do Deus vivo, compassivo e cheio de misericórdia, e sua identidade de povo escolhido e enviado em missão no mundo e para o mundo. Assim, a vivência em comunidade, apoiada aos ensinamentos de Jesus, nos faz perceber o quanto Deus que se compadece, vê e toma conhecimento do sofrimento injusto do povo, e somente uma experiência libertadora poderemos edificar uma sociedade justa e fraterna.

${ }^{765}$ ANDRADE, P. F. C. de, Fé e eficácia: O uso da sociologia na teologia da libertação. 1991. p. 218, (Coleção Fé e realidade; 31). 


\section{4 - Uma Igreja mais solidária aos excluídos a luz da descida de Cristo a mansão dos mortos}

Não se pode negar que Cristo ao descer a mansão dos mortos se compadece se solidariza com aqueles que morreram. A kenosis de Cristo chega ao seu extremo quando atinge o mundo inferior. Se solidarizar-se também é um gesto cristão. Por isso, pensar numa Igreja solidária, numa sociedade latino-americana, com todos os seus desafios e dificuldades sociais, é percebê-la como uma instituição que está a serviço da salvação do mundo, deste modo como Cristo desce ao mais baixo das regiões inferiores para em seguida subir glorioso para estar junto ao Pai.

Assim como se solidarizou com os pobres e os pecadores, com os oprimidos e marginalizados durante sua vida terrena, acolhendo-os, perdoando-os e libertando-os, Jesus quis solidarizar-se com toda a humanidade, passando pela experiência de morte. Ao descer aos abismos do Sheol, Jesus solidariza-se com os cativos da morte, incapazes de se libertar por si mesmos, liberta-os da solidão e do abandono a que estavam condenados, e abre-os às relações de amor e de comunhão ${ }^{766}$.

É na teologia do mistério pascal, elaborada por Hans Urs von Balthasar, que se desenvolve amplamente o significado dessa solidariedade. A descida do Filho à morada dos mortos é a última consequência da missão redentora, que recebeu do Pai. Ele partilhou em nossa condição humana, não só pelo ato de morrer, mas também por ter estado morto. Nesse sentido, deve ser valorizado o silêncio da tradição, sobre o que aconteceu no período de tempo que se estende à morte de Jesus. Esse silêncio faz parte da realidade da morte, pela qual Jesus quis também passar, para solidarizar-se com a humanidade ${ }^{767}$.

Hans Urs von Balthasar, afirmou que já na agonia do Horto aparece a disposição de Jesus em solidarizar-se com os pecadores, sofrendo em lugar deles, a poena damni (castigo dos condenados). Na prisão e codenação de Jesus, ele viu a entrega que Deus fez de seu Filho aos poderes da morte, e a crucifixão como um

\footnotetext{
${ }^{766}$ BALTHASAR, H. U. von, Teología de los tres dias, El Misterio Pascual, p. 139, (Ensayos 151).

${ }^{767}$ Ibid., p. 77-79, (Ensayos 151).
} 
ato judicial de Deus, que castigou a Cristo como maldito, objeto de sua cólera ${ }^{768}$. À luz da experiência de místicos (dentre os quais se destaca a suíça Adrienne von Sperys), ele entendeu o grito na cruz (Mc 15,34//Mt 27,46) como determinante da vivência pessoal de Jesus, do abandono por parte de Deus, e a passividade de Jesus após a morte, aos moldes da teologia vétero-testamentária ${ }^{769}$.

O mistério da descida de Cristo à morada dos mortos, contempla este silêncio de Jesus e da sua presença nas situações de morte, assim como na marginalização, exclusão e abandono experimentado por milhões de pessoas ao longo da história da humanidade. O Cristo que foi crucificado, morto e sepultado e que desceu à morada dos mortos, continua sempre descendo aos "infernos" da humanidade, continua indo ao encontro dos que vivem oprimidos e a margem da sociedade, de todas as vítimas da violência e da crueldade, da fome e da doença, do abandono e da solidão.

É esta solidariedade presente e atuante na Igreja, a exemplo de Cristo, que nos faz se aproximar e se compadecer do outro. A solidariedade de Cristo pela humanidade deve inspirar essa vontade de transformação, de desenvolvimento e anseios, por uma libertação de estruturas opressoras, e que, faz da Igreja uma fonte de esperança para os mais pobres e oprimidos ${ }^{770}$.

A vida e a atividade da Igreja são profundamente afetadas pelas transformações socioculturais da sociedade moderna, por isso, existe uma unidade profunda entre o plano salvador de Deus e as aspirações dos homens, entre a história da salvação operada por Deus e a história humana, e que a construção do Reino de Deus envolve a todos, homens e mulheres. Assim sendo, o humano, o social, o cósmico, o trabalho, a vida econômica e política têm valor em si mesmos e integram o desígnio criador-salvador de Deus sobre a humanidade ${ }^{771}$.

Toda a vida do homem na sociedade estaria pautada à luz do Evangelho. Desta forma, os fatos e as dificuldades do cotidiano se tornavam os "sinais dos tempos”, em que a Igreja deveria se comprometer 772 . "Aos em que a Igreja há de enfrentar, neles se manifestam os sinais dos tempos, que apontam o futuro para onde vai o movimento da cultura. A Igreja deve discerni-los, para poder

\footnotetext{
${ }^{768}$ Ibid., p. 142-145, (Ensayos 151).

${ }^{769}$ GUERRIERO, E., Hans Urs von Balthasar, Madrid, San Pablo, 2008, p. 102-122.

770 MUÑOZ, R., Nueva conciencia de la Iglesia en América Latina, Salamanca: Ediciones Sígueme, 1974, p. 150

${ }^{771}$ Ibid., 1974, p. 293-294

${ }^{772}$ Ibid., 1974, p. 294
} 
consolidar os valores e derrubar os ídolos que alentam esse processo histórico"773. À luz do Evangelho, a sociedade poderia conhecer e compreender o mundo, se reconhecer na história como o povo escolhido por Deus e testemunhar a ação salvífica de Cristo $^{774}$.

$\mathrm{Na}$ Conferência de Puebla, deixa evidente a crescente solidariedade na Igreja quando expressa a opção pelos pobres. Tem-se um compromisso da Igreja com os pobres e oprimidos, assim como, uma clara e profética opção preferencial e solidária pelos pobres ${ }^{775}$. Ao compartilhar dos mesmos princípios da Conferência de Medellín, Puebla acentua: "vemos, à luz da fé como um escândalo e uma contradição com o ser cristão a crescente brecha entre ricos e pobres (...) pecado social de gravidade tanto maior por dar-se em países que se chamam católicos e que têm condições de mudar ${ }^{776 "}$.

A Igreja com um perfil mais profético estava nascendo pelos leigos, sacerdotes, bispos e religiosos que, assumia uma missão libertadora em apoio aos pobres e oprimidos ${ }^{777}$. A Igreja estava inserida na história e na vida do povo, procurando superar o dualismo entre o temporal-espiritual. "Unificar, em uma síntese nova e genial, o antigo e o moderno, o espiritual e o temporal, o que os outros nos legaram e nossa própria originalidade"778.

A Igreja da América Latina, ciente da situação do povo, se sentia solidária as angustias e esperanças do povo, especialmente dos mais pobres ${ }^{779}$. Havia o desejo e o empenho em aliviar o sofrimento do povo e libertá-los da opressão e da injustiça.

\footnotetext{
${ }^{773}$ Puebla, 420

${ }^{774}$ Puebla, 267-268

${ }^{775}$ Puebla, $1134-1140$

776 Puebla, 28

777 MUÑOZ, R., Nueva conciencia de la Iglesia en América Latina, 1974, p. 285

${ }^{778}$ Medellín, Introdução, 7; MUÑOZ, R., op.cit., 1974, p. 296.

${ }^{779}$ Gaudium et Spes, n. 1; MUÑOZ, R., op.cit. 1974, p. 291-292
} 
A opção pelos pobres na Igreja latino-americana possui dois significados centrais: a solidariedade concreta com os pobres que leva a uma mudança de lugar social, assumir a perspectiva do pobre, seus interesses, suas dores e anseios, e implica o compromisso da Igreja mesma 'com a pobreza material' e a denúncia com das estruturas injustas que produzem a pobreza e a opressão; - Permitir e criar condições para que o pobre emerja como sujeito eclesial, isto é agente evangelizador de toda a Igreja, e sujeito político social responsável pelas transformações necessárias para o estabelecimento da justiça e de uma nova sociedade. ${ }^{780}$

O Magistério da Igreja expressou o compromisso eclesial já nos documentos eclesiásticos tais como a Gaudium et Spes do Concílio Vaticano II, na Populorum Progressio, e nos documentos das Conferências episcopais nacionais e latinoamericanas, especialmente Medellín e Puebla ${ }^{781}$. Estes documentos acentuam a participação da Igreja na América Latina, na tarefa de libertação de todo tipo de escravidão sofrida pelo povo: econômica, social, cultural e política.

Todos os cristãos são chamados para agir concretamente em favor do desenvolvimento integral e solidário de toda a humanidade. Em Medellín, a Igreja reconhece suas falhas e se compromete a converter-se. Porém, muitos bispos e sacerdotes, mesmo estando de acordo com as propostas de Medellín, temem os riscos e não se colocam inteiramente frente à nova tarefa evangelizadora; outros, não captando a profundidade e a amplitude das mudanças no continente latinoamericano, preferem voltar à antiga "ordem". E haviam aqueles grupos privilegiados de mentalidade conservadora que pensavam que o comunismo tinha se infiltrado na Igreja. O fato é que o chamado de Medellín a uma transformação profunda e rápida das estruturas econômico-sociais não encontrou nos governos e nos grupos dirigentes a acolhida necessária ${ }^{782}$.

Desta forma, a Igreja, diante das mudanças sócio-econômicas, socioculturais e religiosas, apresentava duas perspectivas de ação que muitas vezes pareciam estar distantes, mas, haja vista que isso era resultado das mudanças sociais que interferiram também na forma de pensar da Igreja, ou seja, ou a Igreja promovia uma ação meramente como agente de mudança social ou voltava-se para uma função meramente espiritual.

É justo que se compreenda a ação eclesial, não como uma dicotomia entre o temporal e o espiritual, pois sempre houve a tentativa da própria Igreja em conciliar o temporal e o espiritual. A Igreja, sendo sacramento da ação salvadora universal e integral de Cristo, tinha como missão não somente anunciar a

\footnotetext{
780 ANDRADE, P. F. C. de. Opção pelos pobres no Magistério - Pensamento Social Católico do Vaticano II à Conferência de Aparecida, in: Concilium, n.361, p.27-37, maio 2015.

${ }^{781}$ MUÑOZ, R., Nueva conciencia de la Iglesia en América Latina, 1974, p. 297

782 Ibid., 1974, p. 297
} 
mensagem de Jesus Cristo e comunicar sua graça, mas também inserir o espírito evangélico na ordem temporal ${ }^{783}$. Através da Igreja, Jesus continua a promover sua ação libertadora no mundo, libertando-os de todo o tipo de servidão: dinheiro, miséria, ignorância, injustiça, opressão e pecado. "A função da Igreja correspondia com a expressão do profeta Isaias em que diz: O Espírito do Senhor está sobre mim, por isso me enviou para evangelizar os pobres ${ }^{784}$."

A Igreja, sendo aquela que anuncia o Evangelho de Jesus Cristo, devia lutar pelos valores e pela dignidade do ser humano, se comprometendo com seu desenvolvimento integral e solidário. Desta forma, a ação da Igreja estaria no testemunho do amor de Deus para com os homens, exercendo um serviço em que lhe compete na promoção dos valores evangélicos aos mais necessitados e oprimidos.

O testemunho dos cristãos em adesão a solidariedade da pessoa de Cristo contribui para um mundo mais humano, fazendo com que o sacramento de Cristo na Igreja se torne mais eficaz ${ }^{785}$. Ao assumirem a missão transformadora na sociedade, os leigos se comprometiam para uma libertação, humanização e desenvolvimento do povo. Tal compromisso corrobora a solidariedade no trabalho da promoção humana ${ }^{786}$.

Cristo que sobe até o Pai e se oculta aos olhos da humanidade continua evangelizando visivelmente através da Igreja, sacramento de comunhão dos homens no único Povo de Deus, peregrino na história. A este povo Cristo envia seu Espírito, "que impele cada um a anunciar o Evangelho e que no fundo da consciência faz aceitar e compreender a palavra de salvação ${ }^{787}$.

\footnotetext{
783 “A Igreja é o Sacramento, sinal e instrumento do Cristo vivo agora e ressuscitado, isto é, do Espírito” BOFF, L., Igreja, carisma e poder, 1981, p. 301-302.

${ }^{784}$ Medellín, Educação, 1; MUÑOZ, R., Nueva conciencia de la Iglesia en América Latina, 1974, p. 296

${ }^{785}$ CONGAR, Y., Eclesiologia. Desde San Agustín hasta nuestros dias, 1976, pp. 475-477

${ }^{786}$ MUÑOZ, R., Nueva conciencia de la Iglesia en América Latina, 1974, p. 304

${ }^{787}$ Paulo VI, Evangelii Nuntiandi, 75
} 


\title{
4.4.1 - A Igreja que ouve o clamor dos pobres e dos excluídos
}

Ao rezarmos que Cristo desceu a mansão dos mortos professamos a mortesolidão de Cristo que se compadece pela humanidade, mas também professamos a morte-vitória de Cristo. A solidariedade de Cristo à condição humana até a morada dos mortos libertou a humanidade para sempre. Com efeito, a Igreja, diante da pobreza e da situação de exclusão, empenhou-se em aliviar os sofrimentos e angustias de grande parte da sociedade ${ }^{788}$. Não faltou coragem em promover a libertação dos excluídos e dar-lhes condições melhores de vida. A Palavra de Deus, revelada nas Escrituras, serviu de inspiração para o cumprimento dos valores cristãos e no testemunho de uma dignidade, que estivesse ao alcance de todos.

\begin{abstract}
A questão da Igreja dos pobres encontrará no pós-concílio terreno fértil na América Latina. Desde meados dos anos 60 surgem diversas comunidades inseridas em meios populares onde o povo pobre se organiza eclesialmente, leem a bíblia comunitariamente, oram, constroem laços e se lançam na luta pelas transformações sociais, unidos a seus Padres e Bispos. Elas dão origem a um processo que foi denominado como uma verdadeira eclesiogênese, o nascimento da Igreja dos pobres profundamente inserida na catolicidade. ${ }^{789}$
\end{abstract}

As Conferências Episcopais Latino-americanas de Medellín e Puebla convocaram os cristãos a um comprometimento na construção de uma sociedade mais justa e solidária, onde não houvesse marginalizados e nem oprimidos. A estes, foi percebido um "surdo clamor" por "uma libertação que não lhes chega de nenhuma parte" ${ }^{, 790}$. O apelo promovido, pela causa dos mais pobres e oprimidos, por Medellín, e mais tarde por Puebla, continua repercutindo nas Conferências nacionais dos Bispos da América Latina.

Em razão da realidade latino-americana o Documento de Medellín afirma que "o Episcopado Latino-americano, não pode ficar indiferente ante as tremendas injustiças sociais existentes na América Latina, que mantêm a maioria de nossos povos numa dolorosa pobreza, que em muitos casos chega a ser miséria

\footnotetext{
${ }^{788}$ LIBÂNIO, J. B., Concílio Vaticano II. Em busca de uma primeira compreensão, São Paulo, Edições Loyola, 2005.p. 131

${ }^{789}$ ANDRADE, P. F. C. de. Opção pelos pobres no Magistério - Pensamento Social Católico do Vaticano II à Conferência de Aparecida, in: Concilium, n.361 , p.27-37, maio 2015.

${ }^{790}$ Medellín, Pobreza da Igreja, 14. 2
} 
desumana ${ }^{791} \%$

O compromisso voluntário dos cristãos se expressa simultaneamente em solidariedade para com os pobres, e a denúncia da pobreza material como algo que desagrada a Deus. Os profetas denunciaram a pobreza como um pecado contra Iahweh. Jesus Cristo assumiu a condição de pobre para que todos tivessem vida e vida em plenitude ${ }^{792}$. O testemunho de uma Igreja pobre pode ser considerado como denúncia da pobreza, solidariedade aos empobrecidos e reconhecimento dos outros como irmãos e irmãs.

Para Medellín e Puebla, os pobres são todos aqueles que, por razões econômicas, raciais e culturais, têm pouco ou nenhum valor na sociedade, e com o agravamento da situação foram excluídos dos seus direitos humanos fundamentais. Esta condição dos pobres constitui uma interpelação à missão da Igreja, que deve sempre redefinir sua tarefa diante de uma situação contrária à vontade de Deus.

Uma das formas para atingir a solidariedade é o empenho à comunhão. João Paulo II na exortação apostólica Ecclesia in América já afirmava que o "o encontro com Cristo vivo conduz sempre à conversão e à reconciliação com Cristo e com o próximo, culmina na comunhão de vida com Ele e frutifica na solidariedade com os necessitados"793. Diante dos grandes problemas enfrentados pelos povos latino-americanos, tanto em situação econômica, política e cultural, somos chamados a exemplo do próprio Cristo, a promover a comunhão com o Pai. Ao se deixar transformar pela ação do Espírito Santo, o homem se torna instrumento na promoção da solidariedade e da fraternidade na sociedade ${ }^{794}$. Um dos exemplos que mais inspira a comunhão fraterna e da solidariedade é a imagem da Trindade. Não se pode negar que a expressão do Filho reflete a vontade do Pai, e que pela força do Espírito a Igreja se torna sinal da salvação. Esta comunhão trinitária é o exemplo que faz com que os cristãos se doem de forma a atingir um

\footnotetext{
${ }^{791}$ Medellín, Pobreza da Igreja, 14.1

792 Medellín, Pobreza da Igreja, 14, 8

793 João Paulo II, Exortação Apostólica Ecclesia in America, n. 29. http://www.vatican.va/holy_father/john_paul_ii/apost_exhortations/documents/hf_jpii_exh_22011999_ecclesia-in-america_po.html

${ }^{794}$ Ibid, 3
} 
nível de solidariedade, para alcançar sua comunhão com Deus ${ }^{795}$.

É certo que a prática da justiça é proveniente do próprio ato de fé do cristão. O cristão ao perceber a partir da comunhão, do amor e da solidariedade na comunidade, alimenta em si próprio um sentido de justiça que pode ser manifestada na sociedade (Tg 2,14-17). O lava-pés é outro exemplo de solicitude que Jesus promove ao lavar os pés dos discípulos. Tal atitude expressa comunhão fraterna no serviço solidário uns aos outros (Jo 13,1-16). Não se pode negar que esta atitude solidária é um grande exemplo, no testemunho eclesial, capaz de promover a transformação na sociedade. $\mathrm{O}$ ensinamento de Jesus ao manifestar o amor e a comunhão com Deus se tornam evidente na comunhão e na solidariedade com os mais necessitados (Mt 25,40) ${ }^{796}$. Nos textos bíblicos, Jesus demonstra a toda à comunidade cristã uma ação solidária e fraterna a todos e em especial aos menos favorecidos. A Igreja latino-americana tem seu apoio no empenho à caridade, comunhão e solidariedade, pelos gestos concretos promovidos por Jesus. Assim, a solidariedade nasce da própria iniciativa divina em expressar seu apoio à humanidade limitada e sofredora, está vendo o Deus feito homem pode perceber condutas que sirvam de exemplo a toda a comunidade cristã.

O ponto mais relevante da atuação de Jesus Cristo numa comunidade cristã é a de ser servidor, não para ser servido. Este é o elemento mais relevante de seu ministério. Jesus anuncia o Evangelho respondendo às necessidades do povo que o procura. Por isso, teve compaixão das multidões (cf. Mt 9,35-36).

Um exemplo claro de atuação que Jesus nos manifesta está presente na parábola do Bom Samaritano. Ele coloca toda ênfase no serviço solidário ao próximo. Esta ajuda solidária está desprovida de qualquer preconceito seja de raça, cor, condição social ou religião (Lc 10,25-37). A pessoa de Jesus é o modelo para toda ação evangelizadora da Igreja na sociedade. "Vai, e também tu faze o mesmo" (Lc 10,37).

Atender as necessidades das pessoas, nas condições e no contexto em que

795 TILLARD, J.M.R. A teologia subjacente à Constituição: a Igreja e os valores terrestres. In: BARAÚNA, A Igreja no mundo de hoje, p. 230

796 GONÇALVES, P. S. L., Liberationis Mysterium. O projeto sistemático da teologia da libertação. Um estudo teológico na perspectiva da regula fidei, 1997, p. 237, Tesi Gregoriana, Serie Teologia. 
elas se encontram, deve ser o exemplo dos atos e ações de Jesus. O serviço solidário, presente na sociedade, em prol também dos mais necessitados e pobres, condiz com o discipulado pregado por Cristo. Com efeito, a Igreja presente na sociedade deve dispor de um serviço a exemplo de Cristo, no serviço aos irmãos. Desta forma, a solidariedade deve estar enraizada na fraternidade, na Palavra de Deus e no contexto histórico-cultural de cada pessoa inserida na comunidade, na sociedade. Uma comunidade que se dispõe a evangelizar é de fato uma comunidade que tende a ser solidária ${ }^{797}$.

A solidariedade presente na sociedade faz com que uma comunidade deixe de ser uma simples comunidade e se torna uma comunidade de irmãos. Esta Igreja, esta comunidade é constituída não simplesmente por um corpo doutrinal, mas sim pelo testemunho comunitário de fé e de esperança dos cristãos. A Igreja se tornará sinal do Reino de Deus ao se apresentar, não como instituição assistencial, mas sim como comunidade que testemunha as ações de Jesus, como modelo de conduta na comunidade. $\mathrm{O}$ amor fraterno, a partilha, a caridade, a solidariedade aos irmãos na fé condiciona uma convivência humana e tece relações sociais que correspondam aos ideais do Reino de Deus.

É justo que a Igreja faça crescer, em cada pessoa, a vocação em ser filho de Deus, e de colaborar com a fraternidade humana, já promovida pela pessoa de Jesus. A Igreja tem a tarefa de evangelizar e saber expressar sua palavra profética também com ações, que promovam ações conscientizadoras e de promoção a paz e a justiça. Desta forma, não compete a Igreja servir ao próximo como uma instituição de um poder superior, mas, sim respeitar a dignidade e as capacidades de cada um, compartilhando responsabilidades na tarefa comum de construir um mundo melhor para todos. Na sociedade já não haveria relações de dependência, mas de fraternidade e consciência da dignidade compartilhada.

${ }^{797}$ Ibid., 1997, p. 265, Tesi Gregoriana, Serie Teologia. 


\subsection{2 - Uma solidariedade libertadora na Igreja}

A partir de 1960, apresenta-se na Igreja latino-americana, um forte compromisso social em denunciar as injustiças sociais, e no empenho de condições melhores aos mais oprimidos. Tal empenho, podemos evidenciar nos documentos do CELAM (Medellín, Puebla e Aparecida) e em documentos sociais, o empenho eclesial em vista da promoção humana e de uma conscientização por melhor educação, saúde e organização popular.

Mas, apesar de todo este empenho ainda não era suficiente para a integridade da pessoa humana. Era necessário denunciar também as estruturas que produziam a miséria e a opressão da sociedade, na intenção em promover as necessidades básicas dos menos favorecidos, tendo em vista uma vida mais digna e humana ${ }^{798}$.

A partir destas Conferências latino-americanas, a Igreja toda fez uma opção solidária pelos pobres em vista da promoção humana. Empenhar-se aos mais pobres e necessitados fez com que a Igreja ganhasse espaço na luta pelos direitos humanos. Ao perceber a necessidade de mudanças estruturais, para que se torne possível a realização da paz e da justiça, a Igreja começa a se sentir pobre com os pobres. A mensagem evangélica proferida por Jesus no anúncio do Reino já nos faz conhecer o projeto de Deus pela paz e pela justiça, e não obstante, pelo empenho à solidariedade ${ }^{799}$.

Uma Igreja solidária é aquela que se compromete com a justiça, a pobreza e a opressão, denunciando a desigualdade social. Anunciar a Boa-Nova de Cristo é profetizar mesmo em situações de perseguição. As primeiras comunidades cristãs já sofreram pelas perseguições em defesa da fé, e o mesmo já aconteceu e acontece na sociedade latino-americana. Muitos cristãos já derramaram seu sangue pelo anúncio da mensagem evangélica de justiça e de paz. O testemunho e o profetismo são expressões que denotam a postura do cristão em acolhimento aos atos de Cristo. Apesar dos grandes desafios presentes na sociedade é visível o empenho eclesial como sinal de paz, justiça, de amor e de reconciliação. A mensagem de Jesus nos mostra o quando Deus se preocupa também com os

\footnotetext{
798 BOFF, L., E a Igreja se fez povo. Eclesiogênese: A Igreja que nasce da fé do povo. 1986, p. 152

${ }^{799}$ Ibid., 1986, p. 153
} 
menos favorecidos, e pede aos cristãos um olhar benevolente aos injustiçados e oprimidos. Cristo viveu nossa condição humana, Ele desceu aos infernos para os elevar.

No documento de Santo Domingo, já se tem reconhecido a realidade do martírio presente na Igreja latino-americana, como expressão da solidariedade cristã. Assim, mostra o quanto o Evangelho tem penetrado nas mulheres e homens de nossas comunidades que, a exemplo de Jesus Cristo, entregaram suas vidas pela causa do amor a Deus e aos irmãos.

O Evangelho prega a vida e a plenitude da vida em comunhão com o Deus da vida. Com efeito, a experiência da perseguição e da morte de muitos cristãos, em nosso continente latino-americano, tende a valorizar uma teologia que dá valor a vida, ao permitir compreender que a opção pelos pobres e excluídos é, justamente, uma opção pelo Deus da vida, revelado em Jesus Cristo e em todos os que o seguem fielmente.

Para que a Igreja se torne mais solidária, é necessário reconhecer os inúmeros desafios que a sociedade apresenta. A crise socioeconômica e cultural se torna um grande agravante na vivência do amor, da justiça e da fraternidade. A conscientização por uma sociedade mais justa e fraterna, fez com que na América Latina desenvolvesse um campo de ação, junto aos mais necessitados e excluídos da sociedade, como os grandes destinatários da mensagem evangélica ${ }^{800}$.

A missão da Igreja na América Latina deve viver uma espiritualidade apoiada em duas perspectivas importantes: a primeira no anúncio da Boa-Nova, na mensagem de Cristo e com suas ações que norteiam o cristão, a segunda em denunciar a injustiça e opressão que afastam da vivência comunitária entre irmãos. A espiritualidade deve estar centrada na solidariedade cristã, tendo como base toda ação de Cristo, que se fez solidário a humanidade se encarnando, padecendo, morrendo na cruz, e pela sua morte nos dando a salvação ${ }^{801}$. Somente em acolhimento da ação solidária de Cristo podemos perceber o quanto a Igreja pode corresponder com solidariedade. Agir solidariamente como força transformadora, esta deve ser a ação de toda a Igreja, em vista da paz e da justiça.

${ }^{800}$ GUTIÉRREZ, G., ¿Dónde dormirán los pobres?, 2002, p. 61.

${ }^{801}$ SOBRINO, J., Cristologia a partir da América Latina, 1983, p. 201-202. 
João XXIII, já afirmava ser a Igreja uma "Igreja de todos e em especial a Igreja dos pobres", e que encontramos na América Latina e no Caribe uma terra fértil, mesmo sendo um continente majoritariamente pobre e cristão. Assim, verifica-se que a partir da década de 1960, foi-se formulando, dentro de uma perspectiva teológica, alguns conceitos básicos sobre a pobreza, entre eles podemos constar uma pobreza real (material), como estado escandaloso e não desejada por Deus; a pobreza espiritual, como desprendimento frente aos bens deste mundo; e a pobreza solidária, expressa no compromisso com o pobre e no protesto contra a pobreza $^{802}$.

Toda a preocupação a cerca dos desafios sociais, vida da comunidade eclesial e a um comprometimento a situação da sociedade latino-americana, é um convite ao discernimento crítico da fé cristã em cada momento da história. Para um cristão, ser solidário "significa estar aberto ao que o Senhor quer dizer através de acontecimentos históricos que devem ser lidos e discernidos, conforme o papa João XXIII e o Concílio Vaticano II, como sinais dos tempos" $" 803$. A Igreja deve estar atenta a todos os ângulos da vida do homem presente na sociedade, e estar aberta as grandes mudanças sociais, em vista da comunhão e na promoção da solidariedade. Quanto mais capacidade os cristãos tiverem para ouvir o que Deus tem a dizer através de outras culturas, religiões ou denominações religiosas, mais firme será sua convicção e mais transparente sua identidade cristã ${ }^{804}$.

A evangelização deve se estender em todos os aspectos da vida pessoal e social. A Igreja deve dar esta importância e estar em defesa da construção de uma sociedade, em que a cultura da solidariedade seja identificada como sinal da irrupção do Reino de Deus no meio do povo.

A dignidade da pessoa humana, assim como o diálogo com outras culturas, buscando a promoção da solidariedade, reflete a fidelidade e o seguimento a Jesus Cristo. A Igreja latino-americana deve corresponder a esta fidelidade a Cristo e manifestar atitudes que correspondam a fraternidade e a vida em comum. A paz que se busca na sociedade tem seu fundamento na justiça e na mensagem de Jesus Cristo, que nos fez conhecer o projeto de Deus em que a todos compete a vida e

\footnotetext{
${ }^{802}$ Ibid, p. 11

${ }^{803}$ Ibid, p. 6

${ }^{804}$ Ibid, p. 55
} 
vida em abundância.

Os documentos do CELAM e o próprio Vaticano II já oferecem para a Igreja propostas que podem ser assumidas, que ajudam a nortear a ação dos cristãos, promovendo a paz e a solidariedade na sociedade. Desta forma, "as alegrias e as esperanças, as tristezas e as angústias dos homens de hoje, sobretudo dos pobres e de todos os que sofrem, são também as alegrias e esperanças, as tristezas e as angústias dos discípulos de Cristo" ${ }^{\$ 05}$ que, guiados pelo Espírito Santo e tendo acolhido a mensagem de salvação, devem propô-la a todos. "Portanto, a comunidade cristã se sente verdadeiramente solidária com o gênero humano e com sua história"806. O próprio papa João Paulo II afirmou que "faz parte do ensinamento e da prática mais antiga da Igreja a convicção de estar obrigada, por vocação (...) a aliviar a miséria dos que sofrem, próximos e distantes, não só com o 'supérfluo' mas também com o 'necessário'. Nos casos de necessidade, não se podem preferir os ornamentos supérfluos das Igrejas e os objetos preciosos do culto divino; ao contrário, poderia ser obrigatório alienar estes bens para dar de comer, de beber, de vestir e casa a quem disso está carente" ${ }^{\text {807. }}$.

Podemos apontar duas encíclicas que são de extrema importância no que concerne ao tema da solidariedade no Magistério da Igreja: a Populorum Progressio de Paulo VI e a Sollicitudo Rei Socialis de João Paulo II.

João Paulo II afirma que a Igreja não tem soluções técnicas para resolver o problema do subdesenvolvimento ${ }^{808}$, mesmo sendo ela "perita em humanidade" 809 . Desta forma, a Igreja é movida "a estender necessariamente sua missão religiosa aos diversos campos em que os homens e mulheres desenvolvem suas atividades" $" 810$. O papa afirma ainda que "a exemplo de meus predecessores, devo repetir que não se pode reduzir a um problema 'técnico' aquilo que, como é o caso do desenvolvimento autêntico, concerne à dignidade do homem e dos povos" $" 811$.

\footnotetext{
${ }^{805}$ Gaudium et Spes, n. 1

806 Ibid

807 João Paulo II, Sollicitudo Rei Socialis, n. 31

808 Ibid., 41

${ }^{809}$ Paulo VI, Populorum Progressio , n. 13, 81; João Paulo II, op.cit. n. 41

810 Ibid., n. 41

811 Ibid. 385
} 
Ao ter Jesus Cristo como fonte e base da conduta humana, a Igreja contribui a solução urgente de problemas referentes a injustiça e opressão. Não se pode negar que o ensino social presente na Igreja tem uma missão profética. Por isso "o exercício do ministério da evangelização no campo social, que é um aspecto do múnus profético da Igreja, compreende também a denúncia dos males e da injustiça. Mas convém esclarecer que o anúncio é sempre mais importante do que a denúncia; e que esta não pode prescindir daquilo que lhe dá verdadeira solidez e a força de sua motivação mais alta" 812 .

Percebemos a exigência evangélica, na opção preferencial pelos pobres, colocada por João Paulo II quando diz: "Este amor preferencial pelos pobres, (...), não pode deixar de abranger as imensas multidões de famintos, mendigos, sem teto, sem assistência médica e, sobretudo, sem esperança de um futuro melhor. Não se pode deixar de levar em conta a existência desta realidade. Ignorá-la significaria tornar-nos como o 'rico epulão' que fingia não conhecer o pobre Lázaro, que estava prostrado ao seu portão (cf. Lc 16,-19-31) ${ }^{813}$.

O documento da Sollicitudo Rei Socialis torna evidente a importância da solidariedade, quando esta não é vista de uma forma superficial em relação às pessoas que sofrem injustiças de toda ordem, próximas ou distantes ${ }^{814}$. É com determinação firme e perseverante no empenho pelo bem comum que a solidariedade pode se estabelecer na sociedade.

Paulo VI, por sua vez, afirma que "o desenvolvimento é o novo nome da

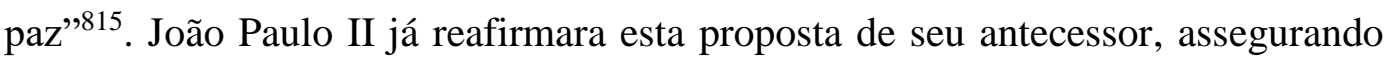
que "deste modo, a solidariedade que nós propomos é caminho para a paz e, ao mesmo tempo, para o desenvolvimento". O procedimento solidário exige a renúncia de todas as formas de imperialismo econômico, militar, político e cultural e ajuda-nos a ver o 'outro' como pessoa, povo ou nação" ${ }^{816}$. João Paulo II, inspirando-se no lema de Pio XII "a paz é fruto da justiça” (opus iustitiae pax) e nos textos bíblicos de Isaías e Tiago (cf. Is 32,17; Tg 3,18), afirma, por analogia,

\footnotetext{
812 João Paulo II, Sollicitudo Rei Socialis. 38; Ibid, 42

813 Ibid, 42

${ }^{814}$ Ibid., 38-40

${ }^{815}$ Paulo VI, Populorum Progressio , 87

816 João Paulo II, opi.cit., 39
} 
que "a paz é fruto da solidariedade" (opus solidarietatis pax). A solidariedade é, pois, uma virtude cristã muito semelhante ao amor ágape, sinal distintivo dos discípulos e discípulas de Cristo. Portanto, a Igreja no seguimento a Jesus, não pode esquecer a dimensão do serviço como condição solidária e de acolhimento aos mais necessitados. A Igreja se torna o lugar vivencia da solidariedade.

Assim sendo, a Igreja latino-americana deve situar-se nas grandes mudanças que acontecem na sociedade e aprofundar em seu modo de pensar e agir, como exigem o Evangelho e a doutrina social da Igreja. Para que se promova a solidariedade é necessária uma constante formação da consciência ética, principalmente aqueles que receberam do povo o encargo de conduzir as políticas econômicas e sociais de seus municípios, estados ou países. Não obstante, as lideranças cristãs, em que muitas vezes são representadas pelos leigos engajados nas comunidades, bispos, sacerdotes, religiosos e religiosas, também necessitam desta formação ético-cristã, contando para isso com a doutrina social da Igreja. Estamos, pois, diante de dois desafios: a formação da consciência crítica dos dirigentes políticos e o testemunho de comunhão na solidariedade a exemplo da comunidade primitiva (cf. At 4,32-35). Com a evangelização torna possível a promoção de relações humanas mais solidárias e fraternas. Para João Paulo II, “a inculturação é o meio, o centro e o objetivo da nova evangelização" ${ }^{817}$ que é conhecer, respeitar, promover a cultura de cada grupo étnico, anunciar o Evangelho a cada cultura para que esta, uma vez evangelizada, expresse em suas próprias formas o conteúdo do Evangelho.

Parei aqui - É evidente que a sociedade latino-americana apresenta inúmeros desafios e problemas, que parecem contrapor a realidade da mensagem evangélica da edificação do Reino de Deus pela paz e pela justiça. Um dos grandes desafios para Igreja latino-americana é ser fonte de comunhão e paz numa sociedade de política partidária, e de dificuldades econômicas. Em contribuição a tais dificuldades, a doutrina social da Igreja também serve de apoio para o agir solidário de uma Igreja voltada aos pobres e excluídos inseridos no sistema político-econômico vigente. A ação eclesial deve se estender para a construção de uma sociedade em que pregue o amor e incentivar o compromisso solidário em

817 João Paulo II: "Discurso aos membros da Comissão Internacional de Catequese", um mês antes da Conferência de Santo Domingo. 
vista dos problemas econômicos, sociais e culturais presentes na sociedade. Assim, com esta ação eclesial todo o cristão pode se comprometer em promover a justiça, a dignidade e a liberdade humana, procurando a satisfação das necessidades vitais de todos os seres humanos.

Com efeito, somente com a força do Espírito Santo a Igreja poderá colaborar com a construção da solidariedade na sociedade, e com a ajuda de algumas pastorais e movimentos sociais. Não é por menos que os documentos das Conferências episcopais Latino-Americana oferecem uma proposta de espiritualidade eclesial, com base a palavra de Deus, contemplativa e orante, pregando o testemunho e a solidariedade cristã.

A ação da Igreja é necessária, porque em uma sociedade onde se identifica injustiças, discriminação, pobreza e exclusão, esquecimento da causa dos pobres, e onde a dignidade humana é ofendida com frequência, a solidariedade se faça presença às vítimas daqueles que insistem em querer deter o poder político, econômico e cultural.

Não se pode negar que os documentos da Igreja exortam para a prática cristã na evangelização e conscientização de todo o povo de Deus. Já desde a Igreja primitiva tinha a atitude em promover a conversão e batizar aqueles que são coerentes com a fé cristã. Desta forma, a Igreja tem o desafio em evangelizar, batizar ou até mesmo testemunhar gestos de caridade ou solidariedade.

A Igreja deve inspirar-se e acolher das ações de Jesus Cristo aquilo que pode nortear o compromisso humano de ação solidária. É inerente a fé cristã todo o acolhimento do dom de Deus, nas ações humanas, pela pessoa de Jesus Cristo. Assim sendo, podemos perceber que uma fé fundamentada nas ações de Cristo rompe com as barreiras do tempo, e a mensagem evangélica passa a ter sua eficácia de geração em geração. A fé continua o tríplice ministério de Jesus, que se identifica com a proclamação da boa notícia da chegada do Reino de Deus, com a libertação e liberdade dos pobres e oprimidos, e pela vivência em comunidade, como discípulos e missionários. Tais ações se tornam a atitude eclesial em vista de uma comunidade fraterna.

Viver em comunidade (koinonia) é desenvolver uma prática que se 
centraliza numa relação de intimidade com Deus. Pela ação do Espírito Santo, percebemos que as atitudes de Cristo se tornam sinais da graça, e que cada ação promovida em comunidade, em vista do bem comum entre os irmãos ${ }^{818}$ é chamado de diakonia.

Na conferência Episcopal Latino-Americano, de Santo Domingo, já exortava que as atitudes da Igreja tivessem como fundamento as próprias atitudes de Cristo. Atitudes proféticas que expressassem os valores humanos em decorrência dos grandes desafios sociais: "Promover e formar o laicato para exercer no mundo sua tríplice função: a profética, no campo da palavra e do pensamento, de sua expressão e valores; a sacerdotal, no mundo da celebração e do sacramento, enriquecida pelas expressões da arte e da comunicação; a real, no universo das estruturas sociais, políticas e econômicas" ${ }^{\text {"19 }}$.

Para a prática de uma ação solidária, poderíamos afirmar que é necessária uma consciência da realidade em quem se vive. Conhecer o sofrimento daqueles dos mais aflitos, sentir compaixão e as causas do sofrimento humano, já são os primeiros passos para que a solidariedade se desenvolva na sociedade. Os cristãos podem perceber em Jesus o empenho, por ele depositado, àqueles que sofriam por causa da injustiça humana. Jesus se pôs ao lado dos mais necessitados, oprimidos e pobres assumindo ser solidário a eles, compadecendo do sofrimento dos mesmos para superar a injustiça humana.

Perceber as necessidades humanas para acentuar a prática da solidariedade é uma possibilidade, no entanto, o princípio teológico nos apresenta a marca da atitude solidária presente na pessoa de Jesus. Jesus se encarnou no seio da humanidade, para poder assumir em plenitude o sofrimento humano. A humanidade de Cristo se torna um compartilhar do sofrimento humano. Jesus se torna solidário a humanidade quando passa a conhecer nossa fraqueza, e se esforça por superar os desafios e obstáculos que impedem a dignidade humana. $\mathrm{O}$ sofrimento de Jesus em vida é o impulso a verdadeira solidariedade, compartilhando com o pobre as fraquezas e os desafios da própria vida.

O anúncio da Boa Nova pregado por Jesus, apesar de estar focado na

${ }^{818}$ KÜNG, H., La estructura carismatica de la Iglesia, in: Concilium. n.1, 1965, p. 45

${ }^{819}$ Santo Domingo, n. 254. 
conversão das nações, e querer que todos tenham acesso a salvação, tem também como objetivo apresentar um anúncio que seja direcionado aos mais pobres e necessitados. É presente nos evangelhos que os bem-aventurados seriam os pobres ou pobres de espírito. Desta forma, teríamos um sentido de solidariedade que pode se desenvolver como uma forma de protesto, ao reconhecer a pobreza material que oprime e desumaniza. A Igreja da América-Latina deve reconhecer a realidade da sociedade, e empenhar por uma solidariedade que conscientize dos grandes problemas e desafios, que escandaliza o continente latino-americano.

A solidariedade cristã deve estar fundamentada numa prática espiritual em que as ações de Cristo e a análise social e econômica, devam corresponder com uma atitude que promova a fraternidade e a paz. A solidariedade deve estar unida aos projetos de Deus, e jamais deixar de ver a realidade da pobreza e da miséria como causa de estruturas injustas e opressoras.

A Igreja latino-americana deve empenhar com ações solidárias que permitam mudanças e transformações sociais. Não se pode negar que se encontramos em nossa sociedade a pobreza e a miséria, é porque existe alguém que se beneficia com estas situações. É evidente a exploração e o enriquecimento de poucos, enquanto a maioria da população se encontra em extrema miséria.

Para uma ação solidária requer atender o mais necessitado, para que este não se sinta a margem da sociedade, escravizado por um sistema que oprime. As desigualdades presentes em nossa sociedade demonstram o quanto é injusto supervalorizar alguns e desconsiderar ou desprezar outros, que se encontram numa situação econômica menor. A solidariedade não é algo abstrato, apenas conceitual, mas motivados por um desejo em querer ver o melhor para a sociedade em que se vive, os cristãos podem desenvolver gestos concretos na prática da hospitalidade, assistência e cuidados àqueles que mais necessitam. As palavras dos cristãos devem estar acompanhadas de gestos concretos ao serviço de quem mais precisa.

Ser solidário é compartilhar do modo de viver do Evangelho. Uma nova forma de agir se torna evidente quando se dedica a prática da solidariedade. Uma nova forma de ação de comunga com o Evangelho e com as atitudes de Jesus. Ao conhecer Jesus, que se manifesta solidariamente com as nossas fraquezas, 
conhecemos também, o modo como o qual Jesus agiu e que assim, se tornará o modo pelo qual podemos agir na sociedade.

A prática da solidariedade compete a uma mudança de postura e de mentalidade. Encontramos em nossa sociedade atitudes marcadas pelo consumismo e pelo individualismo. Atitudes estas em que se tornam desafios para a construção de uma sociedade alicerçada na fraternidade e no bem comum entre irmãos. Com efeito, a caridade e a fraternidade passam a contribuir no rompimento de alguns paradigmas existentes em nossa sociedade, que permitem o sentimento de angustia e depressão causados individualismo. Por outro lado, em sociedades mais desenvolvidas encontramos um grande vazio existencial, em que a falta de ânimo e de esperança se tornam características de uma sociedade, em que o sentido de solidariedade não está bem desenvolvido. Desta forma, muitas pessoas acabam por se acostumar a viver fechados e isolados em si mesmos, e desmotivados em abrir-se a prática da partilha e da solidariedade.

Quando não se tem a solidariedade, rompe-se com a esperança em ver uma sociedade de paz e de fraternidade. Uma forma de superar a ausência da solidariedade é realizando uma análise e reflexão da sociedade atual, e aceitar que cada pessoa é também responsável pela construção de um mundo mais fraterno, humano e justo.

Os cristãos da América Latina podem contribuir mutuamente por uma convivência e com um despertar para uma sociedade mais solidária. Uma mudança social não ocorre de uma forma rápida e espontânea, mas requer um empenho e esforço dos cristãos para uma mudança de consciência. 
A atitude profética dos cristãos no empenho a justiça social faz com que a Igreja não esteja à margem dos desafios sociais, mas caminhando ao lado do povo pode dar a ele uma assistência necessária. Os cristãos devem se inserir em nas organizações populares e políticas, reivindicando um espaço onde os ideais do Reino de Deus possam se fazer presença em defesa da vida e da dignidade humana ${ }^{820}$.

Os cristãos latino-americanos deverão se empenhar em cumprir a tarefa incansável pela libertação solidária, e para que isso seja possível, é necessária uma busca pela verdade, e um comprometimento pela justiça. Ao continuar a missão de Cristo, a Igreja "deve tornar cada vez mais viva e operante esta libertação dos pobres, dos oprimidos e dos marginalizados, prestando sua decidida colaboração na construção de um mundo onde todo homem, sem exceção (...), possa viver uma vida plenamente humana (...)"821.

\footnotetext{
820 Outras linhas de ação solidária poderiam ser enumeradas, como por exemplo, a) a experiência do sofrimento a partir do lugar daqueles que sofrem; b) descobrir os mecanismos da falta de solidariedade não aceitando uma solidariedade ingênua, romântica e acrítica; c) experimentar diretamente o que é a solidariedade no compartilhar, exigindo e acolhendo, uma práxis solidária; d) entrar na dimensão política da solidariedade, analisando os mecanismos estruturais da marginalização e opressão; e) abrir-se à comunhão do Pai na graça comunicante do Filho. A partir daí celebrar a vida na ação solidária e receber o influxo espiritual que ela produz. Desfrutar nossa vida em solidariedade, L. BRIONES, "Para educar en la solidaridad. Líneas de acción", In: A.A.V.V., Sobriedade y solidaridad. Madrid, Editorial Popular, 1987, p. 78-86; O Estado e a Igreja não podem se confundir, e nenhuma Igreja pode utilizar o Estado para obter vantagens institucionais o para garantir privilégios, ou então pretender através do Estado impor uma visão particular da realidade como, por exemplo, o ensino do Criacionismo como alternativa ao Evolucionismo. A Pastoral Social e Política deve estar a serviço da construção do Bem-Comum e de um Estado que garanta e promova os Direitos Fundamentais, para que a humanidade possa realizar-se, conforme a vontade do Criador. Dentro do paradigma da Carta Apostólica Octogesima Adveniens, essa pastoal deve buscar ser fermento na massa, e, se, porventura, a comunidade decida por apoiar alguma candidatura concreta, deve fazê-lo usando critérios objetivos, não corporativistas, que levem em conta, sobretudo, a capacidade dessa candidatura de promover um Estado capaz de exercer de modo melhor a Justiça. ANDRADE, P. F. C. de. O parágrafo quarto da octogesima adveniens e a pastoral político-social. In: REB - Revista Eclesiástica Brasileira, v.69, n.276, p.843-60, out. 2009.

${ }^{821}$ Comissão Pontifícia Justiça e paz, n. 57.
} 
Ser solidário não implica somente um assistencialismo social, desprovido dos valores humanos e da justiça. A prática da solidariedade implica uma conversão, uma mudança de mentalidade, em que é possível apontar uma opção preferencial e solidária pelos pobres, e contra a pobreza ${ }^{822}$. Somente assim, poderemos perceber o ambiente em que vivemos e apontar as causas das grandes maiorias empobrecidas. Esta solidariedade se torna um dos fatores para a mudança estrutural, e para a realização da justiça e da paz social ${ }^{823}$. Perceber os mais pobres e necessitados na sociedade associando-os as próprias ações de Cristo, presente no Evangelho, já começamos a atingir o ideal do Reino de Deus, na construção da justiça e da fraternidade na sociedade.

Assim, vemos que a solidariedade de Cristo é o compadecer dele pela humanidade, "Cristo morreu de verdade e participou da sorte de todos os mortais". A morte não ocorre no fim da vida, mas acontece a cada momento da vida. A vida é mortal e isso vai acontecendo lentamente até acabar de morrer. Esta é a solidariedade de Cristo pela humanidade, Ele se esvaziou, desceu as partes mais íntimas do mundo e do homem, vivendo em condição humana, para elevá-la inteiramente a Deus. É a tentativa da Igreja em solidarizar-se assim como Cristo se solidarizou pela humanidade, afinal

Com sua encarnação tudo assumiu, também a solidão da morte. Ele se abaixou até às últimas raízes da condição humana. Encarnou não só a vida com tudo o que ela significa de possibilidades de encontro, de amor, de crescimento, mas também a morte com tudo o que ela implica em aniquilação, abandono e solidão. 'Mas aquele que desceu é também aquele que subiu' (cf. Ef. 4,10). Se ele desceu, foi para nos assegurar: não temais; eu tenho as chaves da morte; eu venci a morte; eu passei pela porta da última solidão; lá onde ão havia nenhuma presença, estou eu; lá onde não se ouvia nenhuma palavra, está a minha voz; lá onde havia um derradeira abandono, está o meu aconchego; lá onde reinava a morte, mora a $\operatorname{vida}^{824}$.

822 A atitude solidária leva os cristãos a acolher o miserável, o sofredor e o necessitado, experimentando com ele sua angústia e empenhando-se numa ação libertadora. Para realizar esta missão, a Igreja terá que enfrentar três desafios: dar de comer aos famintos, denunciar as estruturas geradoras da fome e oferecer condições para que os pobres se organizem e busquem eles próprios a libertação necessária para uma vida mais digna e humana, MUÑOZ, R., Solidariedade libertadora: Missão da Igreja, 1982, p. 56-61

${ }^{823} \mathrm{O}$ serviço solidário da Igreja não pode, pois, restringir-se à pura assistência, mas terá que contribuir para a humanização libertadora do povo. Um apoio para os trabalhadores do campo e da cidade que dê condições a eles de tomar consciência de seus direitos e suas responsabilidades para que possam se organizar e trabalhar solidariamente por uma sociedade mais justa e fraterna. Ibid, p. 71

${ }^{824}$ BOFF, L., Vida para além da morte, 1986, p. 186. 


\subsection{3 - O respeito à obra criada, a necessidade de uma} solidariedade ecológica.

Quando falamos de uma solidariedade ecológica, temos que levar em consideração que o homem está inserido no ambiente no qual ele está. O teólogo brasileiro, Leonardo Boff já afirma que temos nossa relação intrínsica com o cosmo. "É uma simultaneidade de todas as dimensões, formando uma totalidade complexa e um sistema aberto a novas incorporações. Todos os seres se entrelaçam em redes de inter-retro-conexões no interior desta totalidade complexa, cósmica, terrenal, biológica, antropológica e espiritual ${ }^{825}$ ".

A partir desta realidade intrísinca do homem com o cosmo, Boff compreende a morte não como uma separação entre corpo e alma, mas como uma radical expressão de nossa comunhão com as coisas e com a globalidade do cosmo.

Consideremos que o homem é uma unidade plural de espírito e mundo (corpo). O espírito é sempre encarnado. O corpo é sempre espiritualizado. Caso contrário, não seria corpo humano. A morte não pode, pois, ser qualificada como separação entre alma e corpo, porque não há nada a separar ${ }^{826}$.

Se há uma relação intrínseca do homem, com o cosmo inclusive com a morte, vemos que a doutrina da descida de Cristo à morada dos mortos para Boff, adquire um significado especial dentro da compreensão específica que o teólogo tem da morte, "como crise radical, de-cisão e juízo" e como "cisão e passagem" entre

\footnotetext{
${ }^{825}$ BOFF, L., Virtudes para um mundo possível, hospitalidade: direito e dever de todos, Petrópolis, Vozes, 2005, p. 28, v I.

${ }^{826}$ BOFF, L., Vida para além da morte, 1986, p. 39; De uma maneira muito similar, Karl Rahner entende a descida de Cristo aos infernos dentro do contexto de sua peculiar compreensão da morte - um momento da morte de Cristo - , enquanto intrísico à própria natureza da morte humana que ele padeceu. Entendendo, a morte como um evento singular que diz respeito à totalidade do homeme não somente seu corpo, pelo qual a alma passa a relacionar-se de modo ainda mais amplo com a materialidade do mundo (tornando-se não 'a-cósmica, mas cósmica-universal), Rahner afirmou que a descida do Filho de Deus ao Hades constitui o cumprimento de sua encarnação, depois que sua realidade humana adquiriu, precisamente através da morte, "uma relação ontológico-real com a totalidade do mundo" não apenas trazendo a salvação para todos os homens, mas tornando-se "também em sua humanidade o que Ele, pela sua dignidade sempre foi, isto é, o coração do mundo, o centro mais íntimo de toda realidade criada", RAHNER, K., Sentido Teológico de la muerte, 2010, p. 21-22
} 
um tipo de corporalidade limitado, biológico, restrito a um pedaço do mundo, i.é, ao nosso 'corpo' e outro tipo de corporalidade em relação à matéria ilimitada, aberto, pancósmico que corresponde ao novo modo de ser em que entra o homem após a morte, a eternidade ${ }^{827}$.

Em relação à morte como crise, a doutrina da descida de Cristo à morada dos mortos, significa a afirmação de sua radical solidariedade com o homem. A descida de Cristo à morada dos mortos é a afirmação com roupagens mitológicas, da possibilidade da salvação oferecida a todas as gerações, também do tempo antes de Cristo. Em relação à morte como penetração do homem /.../ no coração da matéria, temos que a

Morte não significa um abandonar o mundo, mas um assumí-lo de forma mais integradora. A globalidade da realidade não constitui uma justaposição disparatada de elementos. Preside-a uma unidade radical; há um coração que unifica tudo num sentido real-ontológico. O homem se encontra enraizado ontologicamente com o mundo, pois ele é, na verdade, um espírito encarnado na matéria. ${ }^{828}$

A afirmação da descida de Cristo à morada dos mortos significa a mudança ocorrida na criação com o ato salvador de Jesus Cristo, a "transfiguração do cosmo".

Com o ressuscitado, Cristo está no mundo, em seu cerne e em suas camadas mais íntimas. Começou já a transfiguração do cosmo. Essa compreensão nos esclarece o significado da afirmação da fé na instrumentalidade universal da humanidade de Cristo. Penetrando o mundo, Ele é sacramento universal de todos os homens, porque todos estão ligados ao mundo. Todos os homens assim estão em contacto, consciente ou inconscientemente, com o Cristo ${ }^{829}$.

A doutrina da descida de Cristo à morada dos mortos nos faz compreender num sentido real-ontológico e não apenas moral, as dimensões verdadeiras do ato salvador de Jesus Cristo e sua atuação instrumental, presente ainda hoje, na nossa história e no cosmo.

Com efeito, com esta "transfiguração cósmica", promovida pelo Cristo

${ }^{827}$ BOFF, L., Vida para além da morte, 1986, p. 39; Depois da morte, a alma de Cristo não se tornou acósmica, sem relação com o mundo material, mas tornou-se pancósmica. O Cristo ressuscitado está em relação salvífica com todo o universo, ele recapitula 'tudo o que existe no céu e na terra' (Ef 1,9-10). BARREIRO, Á., Manifestou-se assim, 2003, p. 40; Na obra Escatologia Cristã de Maria Clara Bingemer e João Batista Libânio afirma Karl. Rahner como aquele que teria criado o termo "pancósmico". Termo este que apresenta o sujeito humano numa relação mais profunda, mais intensa, mais ampla, com a totalidade, com a unidade do mundo material (LIBÂNIO, JOÃO B., B., MARIA C., Escatologia cristã, 1985, p. 201, 299, Série III - A libertação na História, Tomo X, Coleção Teologia e Libertação); RAHNER, K., Sentido Teológico de la muerte, 2010, p. 21-22

${ }^{828}$ BOFF, L., Vida para além da morte, 1986, p. 189

${ }^{829}$ Ibid., 1986, p. 190 
ressuscitado e inserido mundo, vemos que é possível desenvolver uma espiritualidade a partir do saber cuidar do ambiente e da obra criada. Aproximarse do Cristo ressuscitado, presente na obra criada, é uma forma de desenvolver uma solidariedade cristã, quando zelamos pelo meio-ambiente, preservamos nossos recursos naturais e busquemos por um bem-estar, de forma a fazer com que o homem viva de uma maneira saudável.

Hoje há uma busca por espiritualidade. Quer dizer, estamos cansados de raciocínios, pensamentos e teorias. Mais cansados ainda estamos de consumo de bens materiais e de estímulos que nos ocupam totalmente a mente. Queremos sentir o outro lado das coisas, porque tudo tem o seu outro lado. (...). Temos o nosso corpo, com o qual estamos presentes uns aos outros e entramos em contato com todas as energias da Terra e do universo ${ }^{830}$.

Se Cristo manifestou seu amor solidário no mundo, uma civilização que manifesta o amor e a fraternidade entre irmãos é o reflexo do empenho desta mesma solidariedade. Uma sociedade mais justa, mais humana é comprometida em defesa ao meio ambiente. A solidariedade se faz em respeito ao mais próximo como irmão e em respeito e valorização do meio ambiente. Preservar o meio ambiente, a natureza, o ambiente em que se vive se torna também uma defesa a própria vida.

A espiritualidade é uma dimensão de cada ser humano, mesmo de quem não possui nenhuma expressão religiosa, mas busca viver no amor, na solidariedade e na compaixão, especialmente para com aqueles que mais sofrem. Este é um ser espiritual. Quanto mais espiritual, mais irradia bondade e todos se sentirão bem estando junto dele. ${ }^{831}$

A Igreja deve também empenhar na promoção de uma sociedade mais fraterna, e num ambiente em que possa proporcionar a fraternidade e o amor. A obra criada não é sinal de pecado e de afastamento de Deus, mas sim, instrumento para alcançar a Deus. Não falta na Igreja incentivos que proporcione uma ação que permitam anunciar o Reino de Deus, denunciar as injustiças aos mais pobres e a degradação do ambiente em que eles vivem.

O Documento de Santo Domingo já afirmara a importância da obra criada como uma aliança de Deus com a humanidade. Deus ao criar viu que tudo era bom, e por isso a não preservação da natureza ou do ambiente em que se vive se torna um desrespeito a ação de Deus no mundo, e consequentemente, aos próprios

${ }^{830}$ BOFF, L., A casa comum, a espiritualidade, o amor, 2017, p.77

${ }^{831}$ Ibid., 2017, p.79 
seres humanos que compartilham deste mesmo meio ambiente ${ }^{832}$. Santo Domingo propõe um desenvolvimento em que comunga com crescimento econômico associado ao respeito ecológico. A natureza não compete a privilégios de uma minoria, muito pelo contrário, a todos compete zelar e comprometer-se por um desenvolvimento sustentável ${ }^{833}$.

Empenhar-se em defesa da vida é lutar também pela preservação da natureza. Um agricultor, que necessita plantar para o sustento de sua família, não pode ser impedido de preparar a terra, derrubando um pedaço da mata. Um índio, que necessita da pesca e da caça para sobreviver, não pode ser impedido de pescar e caçar. Um dos grandes problemas da humanidade hoje é o desequilíbrio ecológico. A contaminação das águas dos rios e oceanos, a destruição das matas, o lixo que contamina e traz doenças às populações das periferias urbanas, a poluição do ar, tudo isso tem trazido enormes prejuízos ao sistema ecológico, e em consequência, às populações mais carentes ${ }^{834}$.

Valorizar o ambiente em que se vive é contribuir com uma solidariedade ecológica. O homem compartilha do ambiente em que se vive, assim é justo que ao preservar a obra criada já contribuímos solidariamente com aqueles com quem compartilhamos o ambiente em que vivemos. Ao falarmos de uma espiritualidade cósmica podemos dizer que,

Somos parte da natureza e, com a racionalidade e sentido de medida, tiramos dela o que precisamos. Por isso não os cabe relacionar com ela como se estivéssemos de fora ou acima dela, como quem se faz seu dono e a domina. Mais que tudo, devemos nos sentir junto dela como irmãos e irmãs, nos extasiando com sua beleza, nos comovendo com as chagas que lhe infligimos por causa de nossa voracidade de enriquecimento e cuidando dela para que continue para nós e para as

\footnotetext{
${ }^{832}$ Santo Domingo, n. 169

${ }^{833}$ Santo Domingo, n. 169

${ }^{834}$ Este teólogo aponta cinco problemas que se tornam um desafio para os defensores do sistema ecológico mundial: a) o aumento da população e a insuficiência de alimentos em decorrência da injusta distribuição dos mesmos; o crescente desnível entre o crescimento demográfico e o aumento da produção de alimentos; b) o esgotamento das reservas naturais associado ao uso descontrolado das matérias-primas; c) a poluição do ar nociva à vida humana, vegetal e animal; a devastação de florestas e a destruição da cobertura vegetal que causam empobrecimento do solo e a extinção de muitas espécies de animais; a poluição das águas de rios, lagos e mar, escasseando a água doce; a poluição derivada da urbanização descontrolada e, finalmente a poluição atômica causada pela radiação nuclear. A poluição afeta a saúde do ser humano colocando em risco sua sobrevivência; d) a corrida armamentista com sua monstruosa capacidade de destruição; e) a crise ecológica associada à escandalosa injustiça internacional. RUBIO, A., G., Unidade na pluralidade: O ser humano à luz da fé e da reflexão cristãs, ed. 2, 1989, p. 440-444.
} 
futuras gerações ${ }^{835}$.

Mas para que se edifique uma solidariedade ecológica é necessário identificarmos os desafios, para que isso seja viável em nossa sociedade: de princípio grandes monopólios, que controlam as indústrias madeireiras e de mineração, que devastam grandes extensões de matas virgens, para extrair as riquezas naturais, sem a mínima preocupação com o meio ambiente. Usufruem egoistamente de um bem comum da humanidade; à defesa do meio ambiente, não compete somente na luta contra a destruição das matas, mas também denunciar a má distribuição e a perversa mania de destruir para acumular riquezas, por fim, a exploração e exportação de grandes companhias estrangeiras de riquezas naturais dos países mais pobres para os países ricos.

É certo que "a contaminação do meio ambiente, a exploração abusiva e depredadora dos recursos naturais, os arsenais de armamentos nucleares e convencionais etc., são problemas derivados da orientação dada pelo homem moderno à industrialização. Certamente não são problemas criados pelos povos subdesenvolvidos" ${ }^{836}$. Tais situações são problemas que devem ser enfrentados em defesa do sistema ecológico e do meio ambiente em que se vive. Contribuir com a obra criada é também valorizar aqueles com quem convivemos, e isto, inclui até mesmo a grande maioria da sociedade latino-americana, que se encontram prostradas na miséria e no limite entre a vida e a morte.

A preocupação da Igreja latino-americana, com questão ecológica, já fora pronunciada no documento de Puebla ${ }^{837}$ em que tal preocupação acentuara uma prática de solidariedade, em que se podia desenvolver entre os homens e a natureza criada. Os mecanismos e estruturas que depredam, e na natureza são os mesmos que instrumentalizam o ser humano e os povos. Uma mudança de atitude por parte dos cidadãos e da sociedade em geral, não compete somente a uma mudança de mentalidade, mas também uma mudança estrutural ${ }^{838}$.

Não obstante, Santo Domingo também apresenta uma proposta de uma

\footnotetext{
${ }^{835}$ BOFF, L., A casa comum, a espiritualidade, o amor, 2017, p. 91

${ }^{836}$ Ibid, p. 458

${ }^{837}$ Puebla, n. 134, 496, 327, 1236

${ }^{838}$ RUBIO, A. G., Unidade na pluralidade: $O$ ser humano à luz da fé e da reflexão cristãs, ed. 2, 1989p. 459-460
} 
espiritualidade voltada a uma valorização do sentido de Deus, presente na natureza. $\mathrm{O}$ documento aconselha os cristãos a aprenderem com os mais pobres a vivência e a prática da solidariedade e, valorizarem "a sabedoria dos povos indígenas no tocante à preservação da natureza como ambiente de vida para todos" $" 839$.

É evidente que a edificação de uma sociedade que preze pelo meio ambiente em que se vive, pela natureza ou pela preservação ecológica requer da Igreja um permanente diálogo com outros movimentos ecológicos e ecumênicos em torno da defesa do meio ambiente. A solidariedade passa a se desenvolver não somente com aqueles com quem se convivem, mas também com aquilo com que se vive e compartilha. São Francisco de Assis, em seu amor aos pobres e à natureza, mostrou muito bem este caminho de solidariedade aos irmãos e a própria obra criada $^{840}$.

Por fim, o Papa Francisco em sua encíclica Laudato Si, nos apresenta São Francisco como "exemplo por excelência do cuidado pelo que é frágil e por uma ecologia integral, vivida com alegria e autenticidade ${ }^{841}$ ". Assim como "para ele qualquer criatura era uma irmã unida a ele por laços de carinho, pois sentia-se chamado a cuidar de tudo o que existe ${ }^{842}$ ". São Francisco seria aquele que teria inaugurado uma espiritualidade cósmica, pois canta o Sol como senhor e irmão, a irmã e Mãe Terra, as flores dos campos, as aves, as ervas silvestres e até a própria morte, tida como a irmã.

É por esta espiritualidade cósmica que podemos afirmar que com a descida de Cristo à morada dos mortos há uma reconciliação de todas as coisas em Deus. Assim como Cristo, após a morte se espiritualizou com o cosmo, reconcilar-se com Deus é voltar-se para o mundo ao seu redor. O ser humano se caracteriza por um conjunto de relações, como um nó de relações voltado para todas as direções: para cima, para baixo, para dentro e para fora. É a capacidade do homem em se relacionar com todas as coisas, é a vida consciente, aberta a si mesmo, ao outro, ao mundo, e para a totalidade que inclui a realidade ultima.

\footnotetext{
${ }^{839}$ Santo Domingo, 169

${ }^{840}$ Ibid, 170

${ }^{841}$ Laudato Si, 10

${ }^{842}$ Ibid., 11
} 


\section{CONCLUSÃO}

O estudo do tema da descida de Cristo à mansão dos mortos revelou-se mais complexo do que imaginávamos, já desde o início de nosso trabalho. Como nossa pesquisa permitiu perceber, a afirmação da descida aos infernos encontra-se numa peculiar posição de, ao mesmo tempo, não possuir suficiente fundamentação bíblica e ser perfeitamente adequada à mentalidade dos povos das Sagradas Escrituras. Com efeito, não se pode dizer com segurança que os já citados textos das Escrituras, com os quais muitas vezes se pretendeu justificar a afirmação do descensus, refiram-se realmente a ele. Como se não bastassem às dificuldades textuais, para justificar o descensus, nos parece que dentro do contexto bíblico "morrer" e "descer à morada dos mortos" (Sheol, Hades, infernos) eram apresentados como sinônimos.

Desta forma, o significado primeiro para justificar o descensus seria simplesmente a afirmação da morte de Jesus (na cruz), o que não é sem importância, pois não apenas a ressurreição de Cristo foi objeto de controvérsias, mas também sua morte na cruz. A inserção da afirmação no Símbolo, “desceu à mansão dos mortos", viria, pois, afirmar, como dado de fé, a morte de Jesus crucificado e manteria o seu valor como expressão da autêntica fé católica.

Como dissemos, estando a morte e a ressurreição associadas, desde a mais remota tradição cristã (1Cor 15,3), ao mistério de nossa salvação, é bastante compreensível que sua "descida à morada dos mortos" também o fosse. Como vimos os mais antigos Símbolos que mencionam o descensus ad infera o fazem em perspectiva soteriológica. No Oriente, a fórmula do $4^{\circ}$ Sínodo de Sírmio ${ }^{843}$ já trazia claras referências aos efeitos dessa descida (na tradição da pregação aos mortos e de sua libertação); no Ocidente, as explicações de Rufino de Aquiléia ao Símbolo de sua igreja, mostram também, que a interpretação soteriológica era dominante.

\footnotetext{
$843 / . . . /$ que foi crucificado e que morreu, e desceu às regiões subterrâneas, e realizou a economia com os que ali estavam; que vendo-o os guardiões do Hades tremeram (Jó 38,17b), e que ressuscitou dentre os mortos ao terceiro dia. (Sócrates, História Eclesiástica II,37,20 PG 67, 305).
} 
Também interpretada como vitória sobre as potências infernais (interpretação soteriológica bastante comum no período patrístico), a descida aos infernos é entendida como um momento do mistério da Paixão do Senhor e da vitória que, na Cruz, Ele alcançou sobre o Maligno. A interpretação, mesmo revestida de uma imagem simbólica, "mitológica", traduz muito bem o que se crê e se celebra na liturgia: "Cantemos hoje em memória da luta que houve na cruz, este sinal de vitória que todo um povo conduz; nela, coberto de glória, morrendo, vence Jesus!"844. A imagem evita, também, que se entenda a descida de Jesus aos infernos como participação no sofrimento dos condenados, ideia tardia que, ao nosso entender, não encontra fundamento algum nem nas Escrituras, nem nos Padres.

A afirmação da descida aos infernos vem desse modo, significar (e este acreditamos ser o conteúdo mais importante da afirmação) a exclusividade da mediação de Cristo no mistério da salvação: Jesus Cristo o único Salvador, tanto dos que o antecederam, como dos que o sucedem no tempo da vida terrena. Aqueles que viveram e morreram antes de sua morte e ressurreição são beneficiados pela Redenção por Ele operada, do mesmo modo que, aqueles que vivem e morrem após sua Páscoa.

Do mesmo modo, a afirmação de uma descida de Cristo aos infernos, parece-nos suficientemente apta a expressar a verdade da morte do Senhor, sua “exclusividade salvífica” (o único Mediador, 1Tm 2,5) e o alcance (potencialmente) ilimitado de seu poder salvador (cf. Hb 9,14: "pelo Espírito eterno, se ofereceu a si mesmo a Deus como vítima sem mancha").

Mas, não parece possível pretender fundamentar no referido artigo do Símbolo, questões que ultrapassam esse conteúdo. Estas parecem especialmente ligadas à interpretação da descida aos infernos como pregação aos mortos: não há como se responder quais os destinatários desta pregação, se ela comportava a possibilidade de uma conversão post mortem, ou, menos ainda, responder

\footnotetext{
${ }^{844}$ Hino Pange língua de S. Venâncio Fortunato ("Pange, lingua, gloriosi / proelium certaminis,' et super Crucis trophaeo /dic triumphum nobilem, / qualiter Redemptor orbis /immolatus vicerit"). Tradução conforme Liturgia das Horas II.
} 
questões relacionadas à eternidade (= interminabilidade) das penas do inferno ou da apocatástasis.

Independente dos méritos de tais questões ou de sua compatibilidade ou não com a doutrina da Igreja acerca do inferno ${ }^{845}$, a afirmação da descida de Cristo à morada dos mortos não nos parece adequada para fundamentar respostas afirmativas ou negativas aos problemas que elas apresentam. Após a pesquisa que empreendemos, este parece ser o equívoco principal que afeta a muitos que se propuseram estudar o tema: buscando respostas ou fundamentação para questões que ultrapassam os limites da afirmação do Símbolo, criando problemas de solução difícil, senão impossível.

Tais dificuldades não esvaziam, porém, o sentido e o valor que o artigo do Símbolo contém. Mesmo devedora de uma cosmologia ultrapassada, expressa em uma linguagem, nem sempre acessível, aos que a proferem. A afirmação do descensus ganhou um espaço na doutrina católica, no consenso dos fiéis que em tantas celebrações eucarísticas e práticas devocionais (como rosário) professam: "foi crucificado, morto e sepultado, desceu à mansão dos mortos, subiu aos céus... Amém”.

Mesmo com todas estas dificuldades exegéticas que poderíamos apresentar sobre o descensus, as interpretações teológicas apresentadas pelos padres da Igreja e teólogos contemporâneos contribuem para uma hermenêutica e uma nova forma de pensar à descida de Cristo aos infernos, dentro de nosso contexto social. O objetivo foi não esvaziar o artigo de fé, mas sim, interpretá-lo de forma a torná-lo mais acessível ao nosso contexto atual.

A evangelização é a missão própria da Igreja. A história da Igreja é, fundamentalmente, a história da evangelização de um povo que vive em constante transformação e que busca de por uma condição melhor de vida. A evangelização está nas origens do povo da América Latina. A Igreja faz-se presença nas raízes e

\footnotetext{
${ }^{845}$ A doutrina da Igreja afirma a existência do Inferno e a sua eternidade. As almas dos que morrem em estado de pecado mortal descem imediatamente, após a morte, aos infernos, onde sofrem as penas do Inferno, 'o fogo eterno' (Catecismo da Igreja Católica 1035. Notar a manutenção da linguagem de "descida ao inferno").
} 
na atualidade deste povo latino-americano, para que a evangelização leve a libertação e crescimento em todas as dimensões da vida.

É a atuação de Cristo que pode nortear as ações do ser humano em vista da evangelização. A partir do momento em que Cristo desceu a mansão dos mortos levando a pregação, resgatando, libertando e sendo solidário àqueles que se encontravam no lugar dos mortos, pode despertar na práxis eclesial atitudes semelhantes à de Cristo no hoje e no agora do povo latino-americano.

O "lugar dos mortos", muitas vezes retratados como uma realidade de pósmorte, agora vemos como uma condição existencial, próximo da realidade, na vida do ser humano, e como um lugar teológico, cujo qual se pode desenvolver uma forma de agir e de se expressar à exemplo de Cristo.

Vemos que Deus ilumina as trevas, Deus desce ao mais fundo dos abismos, Deus atinge o nível da humanidade para fazê-la participar da divindade, com a ressurreição de Cristo, os infernos perdem seu significado. Se Jesus superou a morte, o homem pode dedicar-se a superar também os infernos deste mundo. É o vislumbre da aurora, também sobre os "pequenos infernos" de nosso dia-a-dia.

Superar os infernos no mundo, nada mais é do que superar as situações de pecado social, de injustiça, falta de dignidade humana, opressão, pobreza, situações estas que faz com que o ser humano já experimente, em vida, o sentido da morte. Não se pode negar que em muitas ocasiões o ser humano perde o sentido da vida. É o artigo de fé da descida de Cristo à morada dos mortos que traz a possibilidade em pensar que os feitos de Cristo, àqueles que morreram, tem a intenção em ascendê-los, fazendo-os contemplar a luz e a vida que vem de Deus.

Por fim, é Moltmann, que de uma forma exemplar, vem trazer o sentido da esperança quando questiona a descida de Cristo aos infernos: "Por que Jesus deverá ter ido aos infernos e ter chegado ao reino da morte? A resposta provém de sua ressurreição dos mortos: primeiro, para abrir os infernos e destruir seus 
portões; segundo, para anunciar aos mortos o Evangelho da salvação ${ }^{846 "}$. Esta é a esperança que temos, de que nós não estamos abandonados.

Os 'infernos' não é mais inevitável e ninguém mais é obrigado a abandonar as esperanças" (...) "Confiante na redentora 'descida de Cristo aos infernos', cada um pode esperar com o Salmo 139, 8 'Se mergulho nos abismos, estás presente' e cantar com o primeiro hino pascal de Paulo em 1Cor 15,55 'Morte, onde está tua vitória?'. Se ainda houvesse perdidos nos infernos, isso seria uma tragédia para Cristo, que veio procurar o que estava perdido. Se em virtude da ressurreição de Cristo isso vale para os infernos após a morte, valerá mais ainda para a experiência de inferno antes da morte e para aquilo que se costuma dizer 'faz da nossa vida um inferno'. Também nas salas de tortura deste mundo está presente o Cristo impugnado e torturado, arrebatando-nos das angústias ${ }^{847}$.

${ }^{846}$ MOLTMANN, JÜRGEN, No fim, o início: breve tratado sobre a esperança, 2007, p. 181.

${ }^{847}$ Ibid., 2007, p. 182. 
Figura 1

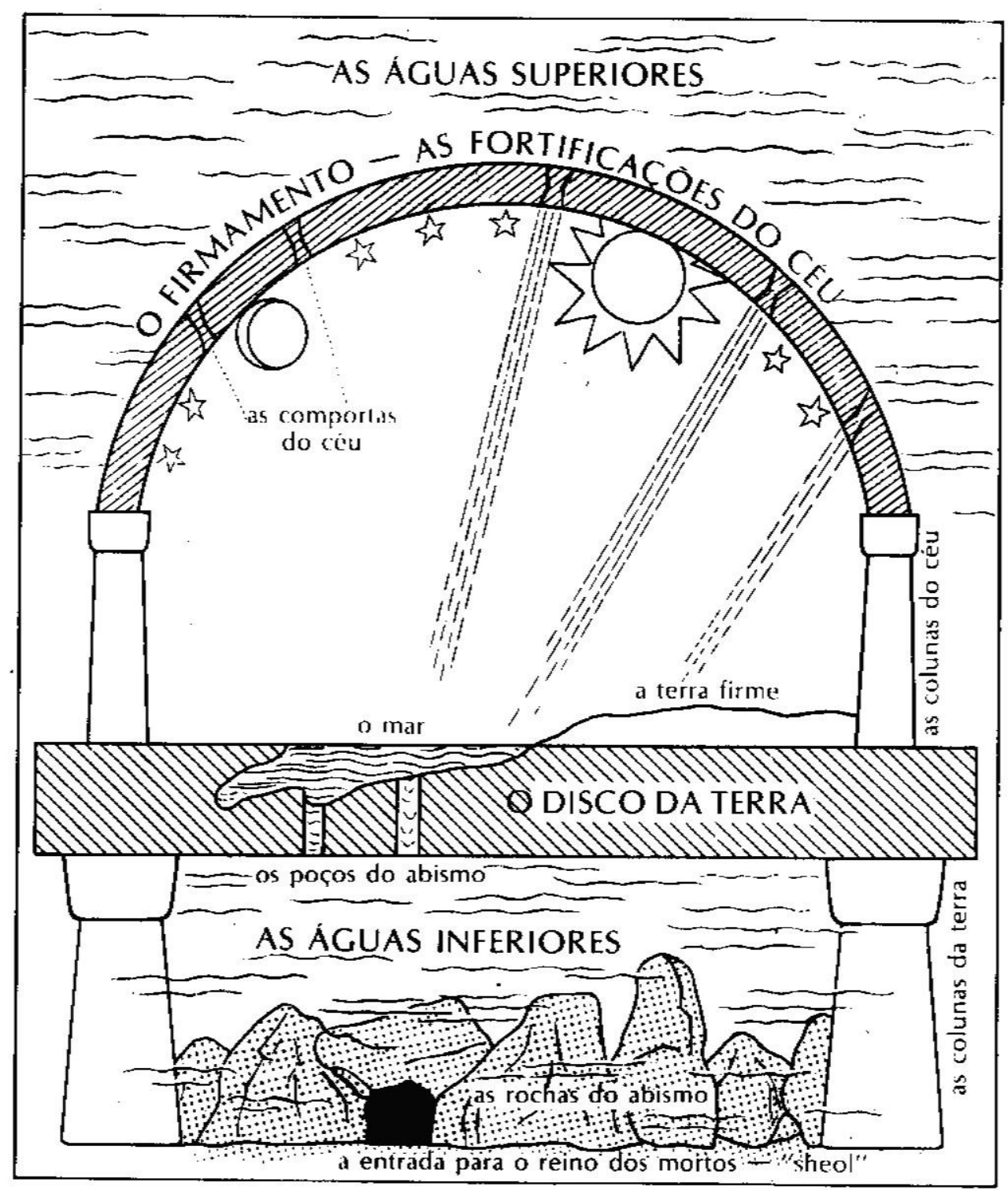

Compreensão de mundo dos antigos semitas (WEISER, A., O que é milagre na Bíblia, 1978, p. 14). 
Figura 2

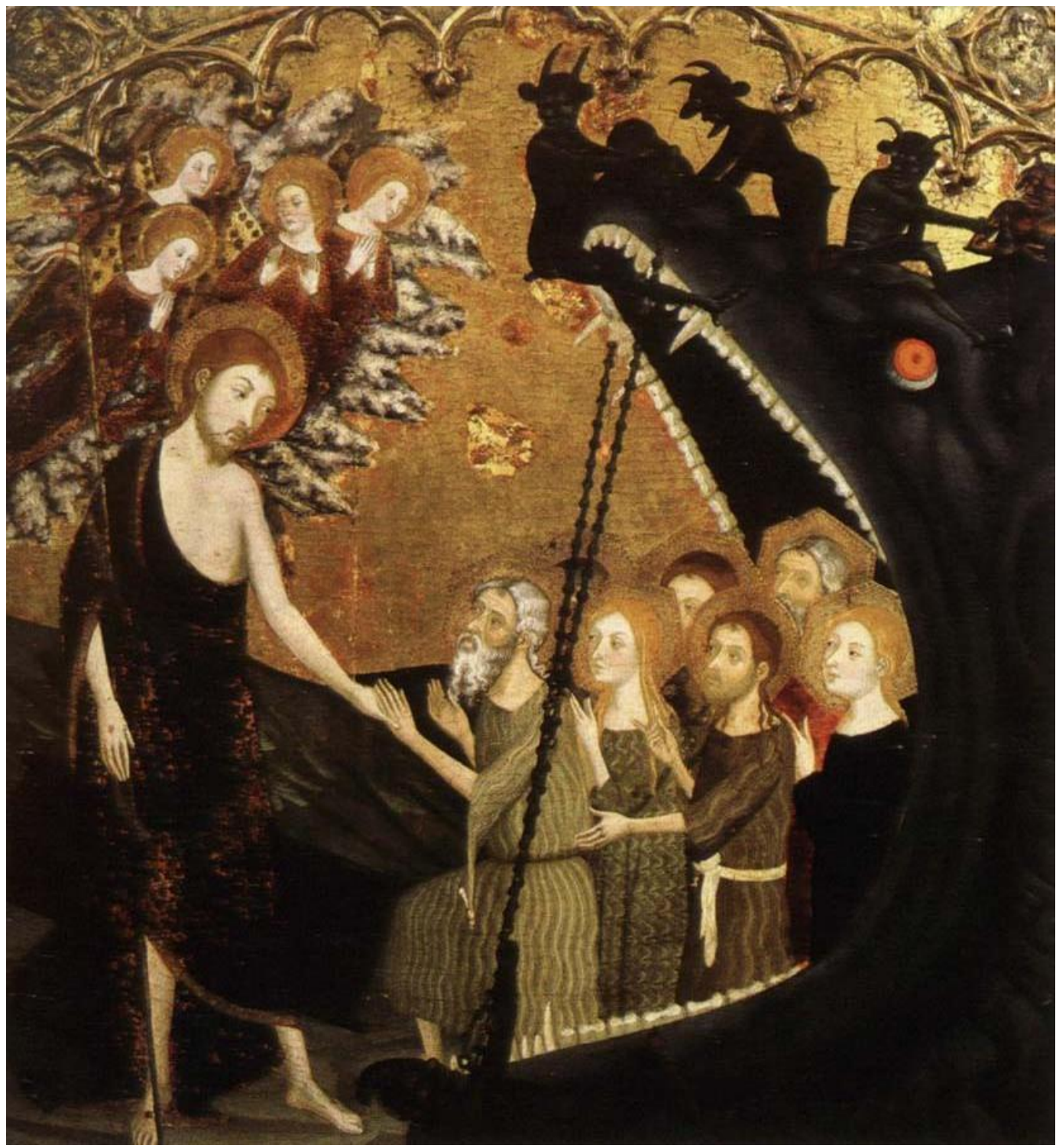

Hades personificado

PITSTICK, A. L., Light in Darkness. Hans Urs von Balthasar and the Catholic Doctrine of Christ's Descent into Hell, 2007, p. 344. 
Figura 3

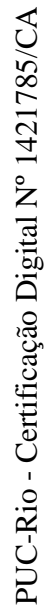

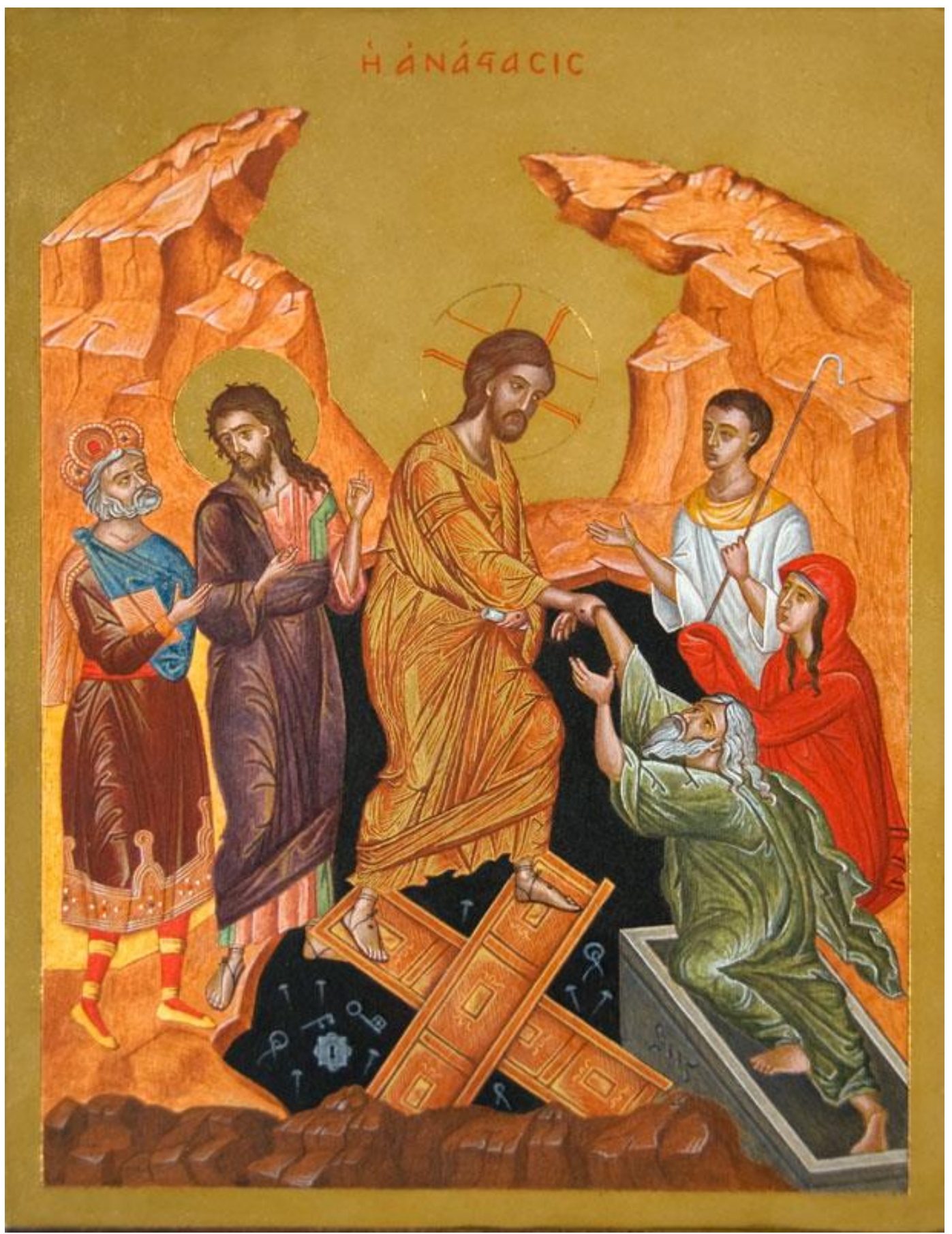

Descensus representado como pregação aos mortos

PASSARELLI, G., Iconos. Festividades Bizantinas, 1999, p. 22 
Figura 4

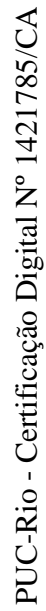

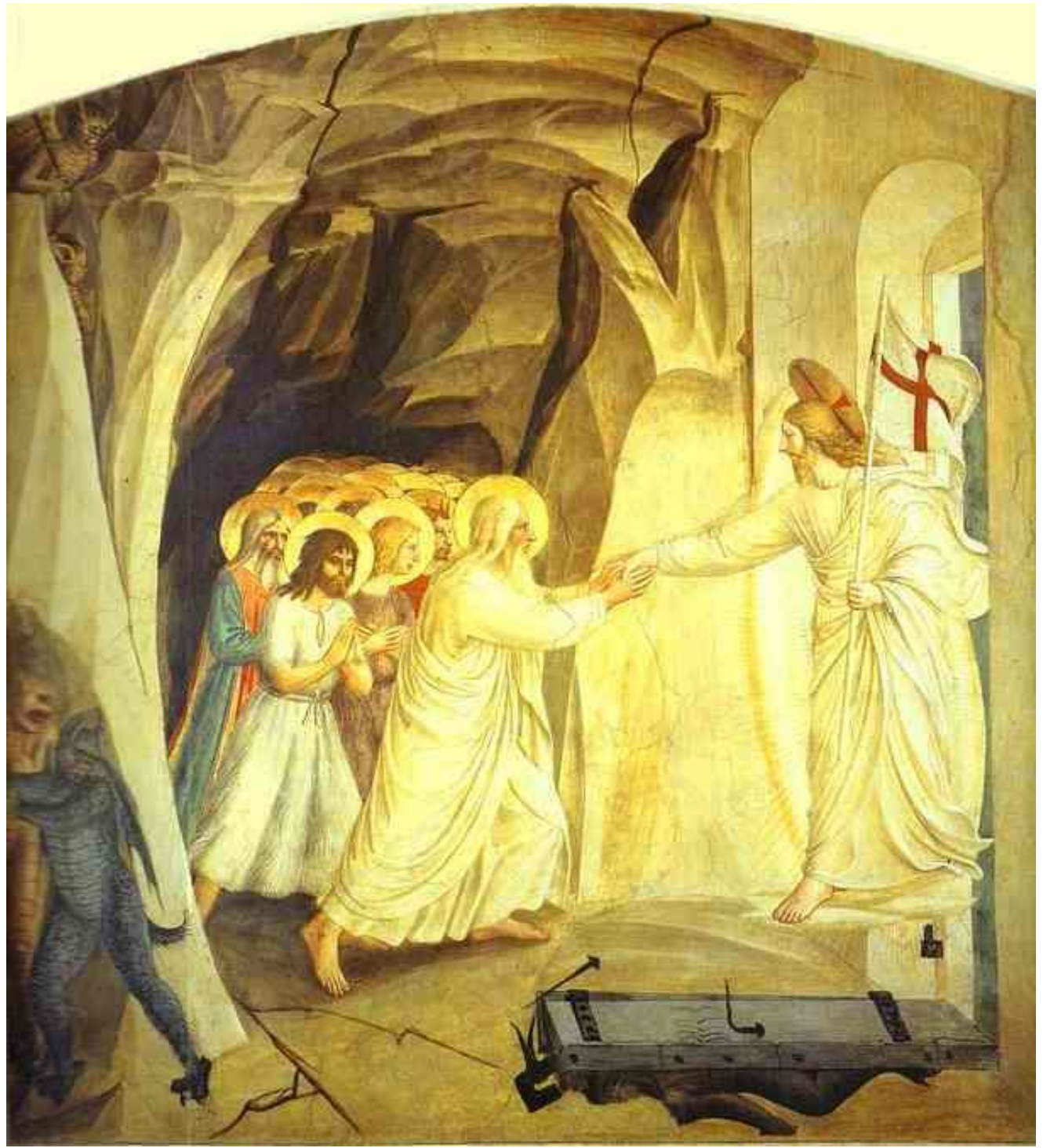

Descensus representado como vitória nos infernos

BARTZ, G., Master of Italian Art - Fra Angélico, 2007, p. 91 
Figura 5

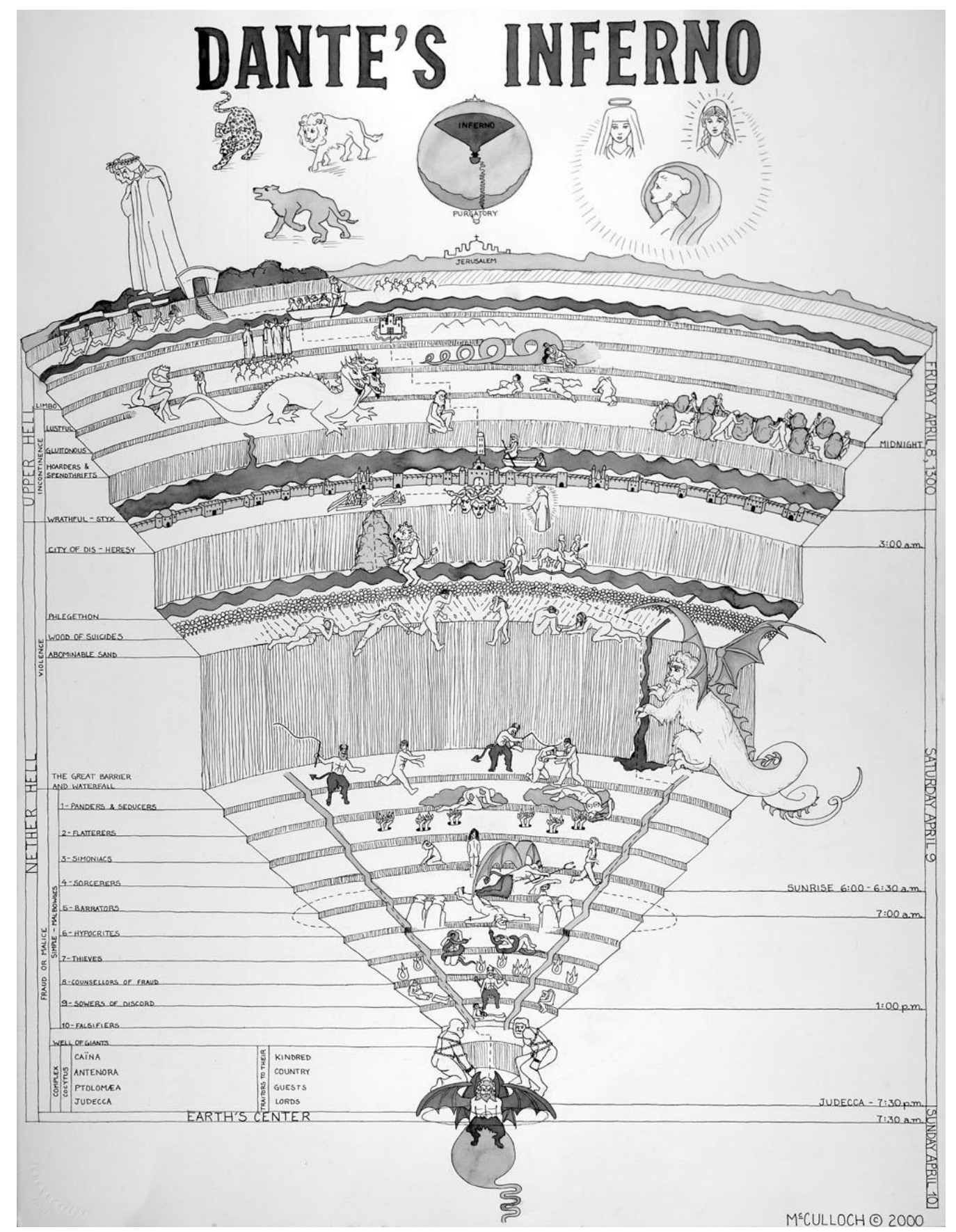

Esquema do Inferno segundo a Divina Comédia

(http://projetodante.blogspot.com/2010/09/o-inferno-de-dante.html, p. 148 
Figura 6

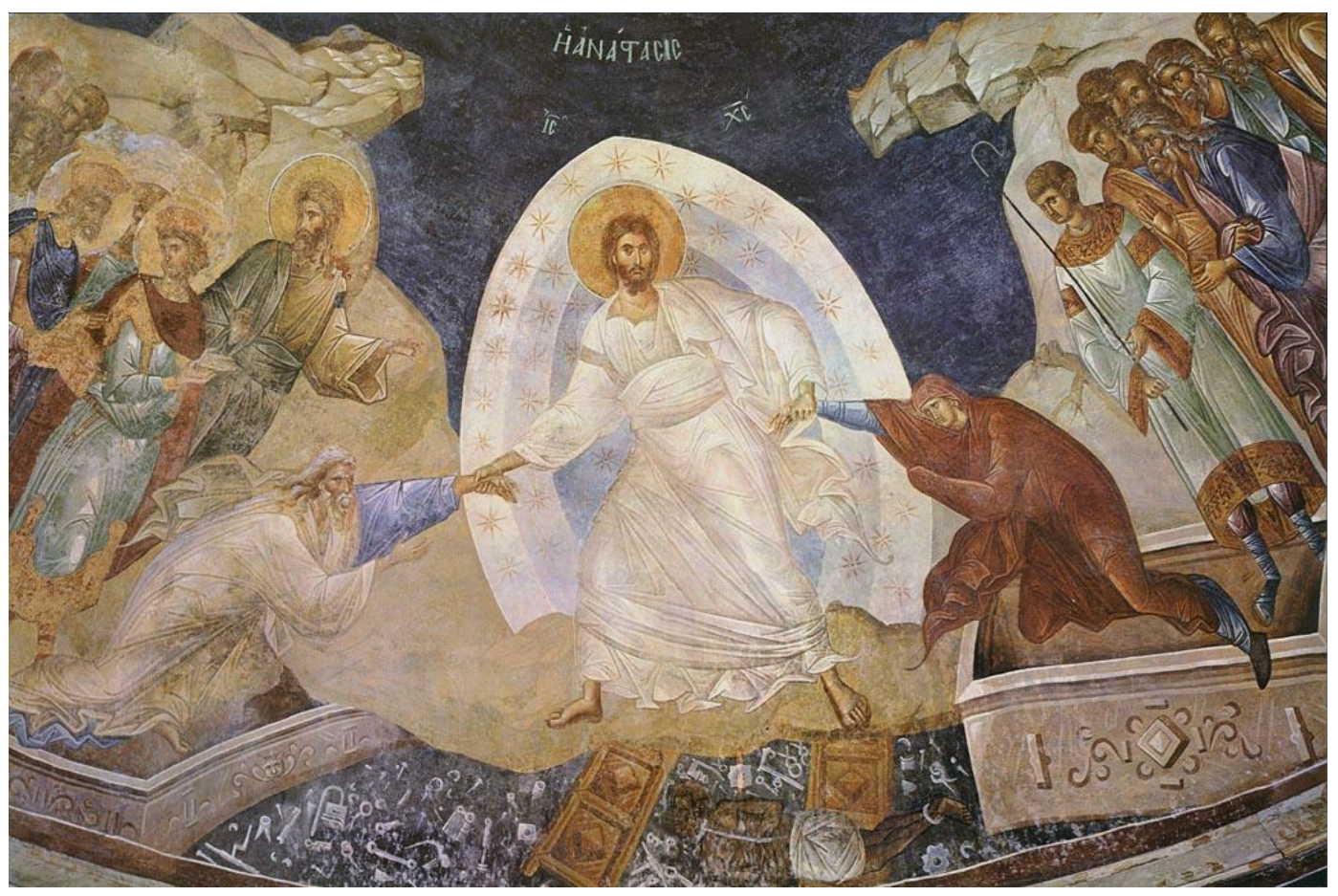

Descensus representado no sentido soteriológico (cf. PASSARELLI, G., Iconos. Festividades Bizantinas., 1999, p. 19). 


\section{Referências Bibliográficas}

\section{Sagrada Escritura}

ANTIGO TESTAMENTO POLIGLOTA: Hebraico, Grego, Português, Inglês. São Paulo: Vida Nova/Sociedade Bíblica do Brasil, 2003.

BÍBLIA: Bíblia de Jerusalém, São Paulo: Paulus, 2004.

BÍBLIA: Bíblia do Peregrino, São Paulo: Paulus, , 2002.

BÍBLIA: TEB Tradução Ecumênica Brasileira, São Paulo: Edições Loyola, 1994.

BÍBLIA: Bíblia CNBB, São Paulo: CNBB/Canção Nova, 2008.

NOVO TESTAMENTO INTERLINEAR GREGO-PORTUGUÊS. Barueri: Sociedades Bíblicas do Brasil, 2004.

NUEVO TESTAMENTO INTERLINEAL GRIEGO-ESPAÑOL, Barcelona: Editorial Clie, 1990.

NOVA VULGATA, Bibliorum Sacrorum auctoritate Ioannis Pauli PP. II promulgata. Libreria Editrice Vaticana, 1986.

SECRETARIADO NACIONAL DE LITURGIA, Antologia Litúrgica. Textos litúrgicos, patrísticos e canónicos do primeiro milênio, Fátima, 2003 


\section{Bibliografia Geral}

AlBERIGO, G.; História dos Concílios Ecumênicos, Paulus, São Paulo $1995,51)$

ANCONA, G., Disceso agli inferi. Roma: Città Nouva, 1999.

ASSUNÇÃO DE MOISÉS. In: Apócrifos da Bíblia e pseudo-epígrafos. São Paulo: Fonte Editorial, 2005.

BALTHASAR, H. U. v., Descenso al Infierno, in Ensayos Teológicos IV. Pneuma e Instituición. Madrid. Ediciones Encuentro e Ediciones Cristiandad, 2008

, El misterio Pascual. In:FEINER, J., LÖHRER, M. (eds.), Mysterium Salutis. Manual de Teología como Historia de Salvación, III, Madrid, 1969

, Mysterium Paschale. In: FEINER, J. \& LOEHRER, M. Compêndio de Dogmática Histórico-Salvífica. O evento Cristo. Petrópolis, RJ: Vozes, 1978. Mysterium Salutis III/6.

_

_, Teología de los tres días. Madrid: Encuentro Ediciones, 2000.

, Tratado sobre el Infierno, Valencia: EDICEP, 1999.

BARTZ, G., Master of Italian Art - Fra Angélico. Printed in China: h.f.ullmann, 2007.

BELLARMINI, R. cardinalis, Opera Omnia I, Disputationes de controversiis christianae fidei adversus hujus temporis hereticos, Josephum Giuliano Editorem, Neapoli, 1836.

BOFF, L. Vida para além da morte, Petrópolis: Vozes, 1973.

BOISMARD, M.-E., Quatre Hymnes Baptismales dans la première épître de Pierre. Paris 1961. 
BOVON, F., El Evangelio según San Lucas II. Salamanca: Ediciones Sígueme, 2002 (Biblioteca de Estudios Bíblicos, 86).

BROWN R., Introdução ao Novo Testamento. São Paulo: Paulinas, 2004. La muerte del Mesías II, Verbo Divino, Estella, 2006

BROWN, R. E.; FITZMYER, J.A.; MURPHY, R. E.; et al, Comentario Bíblico San Jerónimo. Madrid: Ediciones Cristandad, 1972.

CANTALAMESSA R., L'Omelia “In s. Pascha” dello Pseudo-Ippolito di Roma. Ricerche sulla teologia dell'Asia Minore nella seconda metà del II secolo, Milano 1967, 242-259 , O mistério da transfiguração (tradução de Alda da Anunciação Machado), Edições Loyola, São Paulo, 2001.

CARDEDAL, O. G. de, Cristología, BAC, Madrid, 2001.

CHIALÀ, S.; Discese agli inferi, Edizioni Qiqajon, Magnano, 2000

CLEMENTE DE ALEXANDRIA, Les Stromates VI 45,4, Paris : Les Éditions du Cerf, 1999, (Sources Chrétiennes, 446).

DALTON, W. J., Christ's proclamation to the Spirits, A study of the 1 Peter 3:18-4:6, Roma: Editrice Pontificio Istituto Biblico, 1989.

DENZINGER, H., HÜNERMANN, P., (por nós citado como DHü) El Magisterio de la Iglesia : Enchiridion symbolorum definitionum et declarationum de rebus fidei et morum, Barcelona: Herder, 2000.

DE LA PENA, L. R., La pascua de la creación. Escatología. BAC, Madrid, 2007.

DESCIDA DE CRISTO AO INFERNO (Versão Grega). In: Apócrifos da Bíblia e pseudo-epígrafos. São Paulo: Fonte Editorial, 2005.

DI BERARDINO, A. (Org). Dicionário Patrístico e de Antiguidades Cristãs. Petrópolis: Rio de Janeiro, 2002. 
DILlON, R. J., Hechos de los Apóstoles. In: Nuevo Comentário Bíblico San Jerónimo. Estella/Navarra: Editorial Verbo Divino, 2004.

DUQUOC, C., La descente du Christ aux enfers, problématique théologique, in :Lumiere et vie 87 (1968).

, Cristologia Ensaio Dogmático II. O Messias. São Paulo: Edições Loyola, 1996.

ERNESTO M., La discesa agli inferi. Nel giorno del Sabato santo la chiesa “accompagna” Cristo nel sepolcro, in Vita Monastica, 224/2004, p. 53 - 70

EUSÉBIO DE CESARÉIA, História Eclesiástica. VI,12,2. São Paulo: Paulus, 1995 (Patrística 15).

EVANGELHO DE PEDRO. In: Apócrifos da Bíblia e pseudo-epígrafos, São Paulo: Fonte Editorial, 2005.

EVANGELHO DE BARTOLOMEU. In: Apócrifos da Bíblia e pseudoepígrafos. São Paulo: Fonte Editorial, 2005.

FRANGIOTTI, R., Introdução à obra do Pastor de Hermas. In Padres Apostólicos, São Paulo: Paulus, 1995 (Coleção Patrística, 1).

GALOT, J.; La Descente du Christ aux enfers, in: Nouvelle Revue Théologique, Tome 83 (1961). Gesù liberatore. Cristologia II Firenze: Libreria Editrice Fiorentina, 1983.

GESCHÉ, A., L'agonie de La Réssurrection ou La Descente aux Enfers, RTL 25 (1994) 5-29. O Cristo, Paulinas, São Paulo, 2004 (tradução de Carlos Felício da Silveira).

GIRAUDO, C., Num só Corpo. Tratado mistagógico sobre a Eucaristia (tradução Francisco Taborda), Ed. Loyola, São Paulo, 2003. 
GRILLMEIER, Cristo en la tradición cristiana, Salamanca 1997

GOUNELLE, R. La descente du Christ aux enfers. In: Cahiers Évangile, Paris: Éditions du Cerf. no 128, 2004.

La descente du Christ aux enfers. Institutionnalisation d'une croyance. Paris: Institut d'Études Augustiniennes, 2000, (Collection des Études Augustiniennes, 162).

HANAUER, J. E., Mitos, lendas e fábulas da Terra Santa, São Paulo: Landy Editora, 2005.

HAUBECK, W., SIEBENTHAL, H., Nova chave lingüística do Novo Testamento grego, São Paulo: Targumin e Hagnos, 2009.

HEIMANN L.; Pregação aos mortos. Canoas: Editora ULBRA, 2002.

HURTADO, L. W., Come Gesù divenne Dio, (tradução deAngelo Fracchia) Paideia Editrice, Brescia, 2010.

—_ Señor Jesucristo. La devoción a Jesús em el Cristianismo primitivo, (tradução de Francisco J. Molina de La Torre) Sígueme, Salamanca 2008.

IRINEU DE LYON, Adversus Haereses. Livro IV, 27,2, São Paulo: Paulus, 1995 (Coleção Patrística, 4).

Démonstration de la prédication apostolique 78, Paris : Les Éditions du Cerf, 1995 (Sources Chrétiennes, 406).

JEREMIAS, J., Las parábolas de Jesús. Navarra: Editorial Verbo Divino, 1997.

, Teologia do Novo Testamento, Paulus e Teológica, São Paulo, 2004.

„Entre Viernes santo y Domingo de Pascua. In: Abba El mensaje central del Nuevo Testamento, Salamanca, Sígueme, 1999. 
JUSTINO, Apologia II. 4,3-4, São Paulo: Paulus, 1995 (Coleção Patrística, $3)$.

Diálogo com Trifão. 72,4, São Paulo: Paulus, 1995 (Coleção Patrística, 3).

KELLY, J.N. D.; Primitivos Credos Cristianos. Salamanca: Secretariado Trinitario Salamanca, 1980.

KÜNG, H.; ¿Vida eterna?. Madrid: Ediciones Cristiandad. 1983.

KOBELSKI, P., Carta a los Efesios, In: Nuevo Comentario Bíblico San Jerónimo, Estella/Navarra: Editorial Verbo Divino, 2004.

LÍNDEZ, J. V., Eclesiastes ou Qohélet. São Paulo: Paulus, 1999.

LIVRO DE ENOQUE. In: Apócrifos da Bíblia e pseudo-epígrafos. São Paulo: Fonte Editorial, 2005.

LOCHET, L., Jésus descendu aux enfers Paris, Les Editions du Cerf, 1979. La salvación llega a los infiernos, Sal Terrae, Santander, 1980 (tradução de Juan J. Gracía Valenceja)

LUZ, U., El Evangelio según San Mateo II, p. Sígueme, Salamanca, 2001. El Evangelio según San Mateo IV, p. Sígueme, Salamanca, 2005.

MACKENZIE, J.L., Dicionário Bíblico, São Paulo: Paulus, 1983.

MARCHADOUR, A. Morte e Vida na Bíblia, Lisboa: Difusora Bíblica, 2001

MASS, W.; "Discese all'inferno". Aspetti di un articolo di fede dimenticato, in: Communio (italiana) 55 (1981) .

MARTIN-ACHARD, R., Da morte à Ressurreição segundo o Antigo Testamento, São Paulo: Editora Academia Cristã, 2005. 
MELITÃo DE SARDES, Sur la Pâques, Paris: Les Éditions Du Cerf, 1966 (Sources Chrétiennes, 123).

MOLINA, F. C., El Señor de la vida. Lectura Cristológica del Apocalipsis, Salamanca, Sigueme, 1991.

ORBE, A., El 'Descensus ad inferos' y San Irineo, in: Gregorianum, 68, 1987

ORÍGENES, Contra Celso. Livro II, 43, São Paulo: Paulus, 1995 (Coleção Patrística, 20).

, Traité des Principes II, 6,2, Paris : Les Éditions du Cerf, 1978 (Sources Chrétiennes, 253).

PASSARELLI, G., Iconos. Festividades Bizantinas. Madrid: Editora LIBSA, 1999.

PATROLOGIÆ Latina. Edição preparada por J.-P Migne. Turnholti: Typographi Brepols, Editores Pontifici, 1958-1974.

PERRONE, L. De Nicéia a Calcedônia, in. ALBERIGO, G.; História dos Concílios Ecumênicos, Paulus, São Paulo 1995.

PITSTICK, A. L., Light in Darkness. Hans Urs von Balthasar and the Catholic Doctrine of Christ's Descent into Hell, Grand Rapids, Michigan, Cambrige 2007

RAHNER, K., Sulla teologia della morte. Brescia: Morcelliana, 2008.

RATZINGER, J.;Introdução ao Cristianismo. São Paulo: Loyola, 2009.

RUFINUS, T., Expositio (Comentarius). In symbolum, 16. In: DENZINGER, H., HÜNERMANN, P., (por nós citado como DHü) El Magisterio de la Iglesia : Enchiridion symbolorum definitionum et declarationum de rebus fidei et morum, Barcelona: Herder, 2000. 
RIUS-CAMOS, J., READ-HEIMERDINGER, J., El Mensaje de los Hechos de los Apóstoles en el Códice Beza. Navarra: Editorial Verbo Divino, 2004, Tomo I.

SANTAMARIA LANCHO, J.A.., Un estudio sobre la soteriología Del dogma del Descensus ad ínferos: 1 Pe 3,19-20a y la tradición sobre "la Predicación de Cristo en los Infiernos”. 2007. 200 p. Tese (Doutorado em Teologia) Fakultät der Ludwig-Maximilians-Universität München, München, 2007.

SANTO AGOSTINHO, Comentário aos Salmos. 85,18, São Paulo: Paulus, 1995. (Coleção Patrística 9/2,).

SANTO ATANÁSIO, A encarnação do Verbo, 26, 1-2, São Paulo: Paulus, 1995. (Coleção Patrística, 18).

SCHATZ, K.; Storia dei concili. La Chiesa nei suoi punti focali, Edizioni Dehoniane, Bologna, 1999.

SPEYR, A. von , L’expérience du Samedi Saint. In : Communio (edição francesa) VI, I (1981).

STUDER, B., Dios Salvador en los Padres de la Iglesia, Salamanca 1993,

TOMAS DE AQUINO, O Credo. Petrópolis: 2006. , Suma Teológica. São Paulo: Loyola, 2002, vol. III ${ }^{1}$. , Suma Teológica, trad. de Alexandre Corrêa, 2 ed. Porto Alegre, Escola Superior de Teologia São Lourenço de Brindes, Livraria Sulina Editora; Caxias do Sul, Universidade de Caxias do Sul, 1980, vol. II $^{2}$. Suma de Teología. Madrid: BAC, 1994, vol. III.

TESTAMENTO DE RUBÉN. In: Apócrifos da Bíblia e pseudo-epígrafos. São Paulo: Fonte Editorial, 2005.

TESTAMENTO DE LEVI. In: Apócrifos da Bíblia e pseudo-epígrafos. São Paulo: Fonte Editorial, 2005. 
VAUX, R., Instituições de Israel no Antigo Testamento, São Paulo: Vida Nova, 2004.

VAN DER BORN, A.(Org).Dicionário Enciclopédico da Bíblia, Porto: Vozes, 1971.

VIVIANO,B.T., Evangelio según Mateo. In: Nuevo Comentário Bíblico San Jerónimo. Estella/Navarra: Editorial Verbo Divino, 2004.

WEISER, A., O que é milagre na Bíblia, Edições Paulinas, São Paulo, 1978.

WOLFF, H. W., Antropologia do Antigo Testamento, São Paulo: Hagnos, 2007.

\section{Sites}

http://abcdioses.noneto.com

http://www.ccel.org/ccel/schaff/npnf203.iv.viii.ii.xvi.html

http://www.documentacatholicaomnia.eu/04z/z_0393-

0466_Theodoretus_Cyrrhi_Episcopus_Historia_Ecclesiastica_EN.doc.html

http://www.documentacatholicaomnia.eu/04z/z_0393-

0466_Theodoretus_Cyrrhi_Episcopus_Historia_Ecclesiastica_EN.doc.html

http://www.ecclesia.com.br/biblioteca/liturgia/a_divina_liturgia_de_sao_joa o_crisostomo_segunda_parte.html\#II.

http://www.earlychristianwritings.com/text/hippolytus-christ.html

http://www.earlychristianwritings.com/text/hippolytus-christ.html

http://www.earlychristianwritings.com/text/origen123.html

http://www.ecclesia.com.br/biblioteca/liturgia/o_grande_sabado_santo.html 
http://www.vatican.va/holy_father/paul_vi/motu_proprio/documents/hf_pvi_motu-proprio_19680630_credo_po.html Acesso 27/11/2010 22:53

http://www.vatican.va/holy_father/john_paul_ii/audiences/1989/documents/ hf_jp-ii_aud_19890111_it.html

http://www.vatican.va/holy_father/john_paul_ii/speeches/1984/april/docume nts/hf_jp-ii_spe_19840421_pellegrini-polacchi_it.html

http://www.vatican.va/holy_father/benedict_xvi/homilies/2007/documents/h f_ben-xvi_hom_20070407_veglia-pasquale_po.html acesso em 01/12/2010 22:47

http://www.vatican.va/holy_father/benedict_xvi/speeches/2010/may/docume nts/hf_ben-Xvi_spe_20100502_meditazione-torino_po.html acesso em 01/12/2010 $22: 52$

http://www.vatican.va/holy_father/benedict_xvi/speeches/2009/december/do cuments/hf_ben-xvi_spe_20091221_curia-auguri_po.html

http://www.vatican.va/holy_father/benedict_xvi/messages/urbi/documents/h f_ben-Xvi_mes_20090412_urbi-easter_po.html

http://www.vatican.va/holy_father/benedict_xvi/homilies/2010/documents/h f_ben-xvi_hom_20100403_veglia-pasquale_po.html 


\section{Bibliografia para fundamentaçã latino-americana}

ABBAGNANO, NICOLA, Dicionário de Filosofia, São Paulo: Martins Fontes, 2007

ANTONIO ACERBI, Due ecclesiologie. Ecclesiologia giuridica ed ecclesiologia di communione nella «Lumen gentium». Bologne, Ed. Dehoniane, 1975.

AGUER, Héctor Rubén, El fenómeno de la globalización, in: Iglesia in América, Al encuentro de Jesucristo vivo, Ciudad del Vaticano, Libreria Editrice Vaticana, 2001, p. 271-272 (PONTIFICIA COMMISSIO PRO AMERICA LATINA).

ALMEIDA, D. LUCIANO MENDES, O pensamento episcopal latinoamericano, do Rio a Santo Domingo, in: O futuro da reflexão teológica na América Latina (CELAM), São Paulo, Edições Loyola, 1998.

ANDRADE, PAULO FERNANDO CARNEIRO de, A opção pelos pobres e a graça de Deus. Grande Sinal, in: revista de espiritualidade, Petrópolis - RJ, v.38, n.9, p.656-67, nov. 1984.

Opção pelos pobres: fidelidade à mais antiga tradição. Grande Sinal in: Revista de Espiritualidade, Petrópolis - RJ, v.39, n.7 , p.575-86, set. 1985.

A ação política como ação ética e escatológica, in: Grande Sinal, Petrópolis, v. 47, n. 1, p. 35-41, 1993.

A condição pós-moderna como desafio à pastoral popular. In: REB - Revista Eclesiástica Brasileira, Petrópolis, v. 53, n. 209 , p. 99-113, 1993.

Opção pelos pobres no Magistério - Pensamento Social Católico do Vaticano II à Conferência de Aparecida, in: Concilium, Petrópolis - RJ, n.361 , p.27-37, maio 2015.

O parágrafo quarto da octogesima adveniens e a pastoral políticosocial. In: REB - Revista Eclesiástica Brasileira, Petrópolis - RJ, v.69, n.276 , p.843-60, out. 2009. 
Fé e eficácia: O uso da sociologia na teologia da libertação. São

Paulo: Loyola, 1991. (Coleção Fé e realidade; 31).

ANDRZEJ DAŃCZAK, La questione dello stato intermédio nella teologia cattolica negli anni 1962-1999, Pelplin: Wydawnictwo „Bernardinum”, 2008

ANTÓN, ANGEL. La Iglesia de Cristo. Madrid: BAC, 1977, p. 81 El misterio de la Iglesia,Madrid, Ed. BAC, 1986.

BARBOSA, FRANCISCO DE BARROS, A cristologia de serviço $e$ seguimento no debate eclesial e teológico latino-americano, Tese doutoral: Pontificia Universitas Gregoriana, Roma, 1998

BARREIRO, ÁLVARO, Manifestou-se assim, São Paulo: Edições Loyola, 2003

BINGEMER, MARIA CLARA, Inferno e Céu: possibilidade e promessa, in: LIBÂNIO, JOÃO B., BINGEMER, MARIA CLARA, Escatologia cristã, Petrópolis, Vozes, 1985, Série III - A libertação na História, Tomo X, Coleção Teologia e Libertação.

BINGEMER, MARIA CLARA, Teologia Latino-Americana, Raízes e Ramos, Petrópolis: Editora PUC-Rio, Editora Vozes, 2017.

BOFF, LEONARDO, A casa comum, a espiritualidade, o amor, São Paulo, Paulinas, 2017.

Jesus Cristo Libertador, Editora Vozes: Petrópolis, 1972

Virtudes para um outro mundo possível. v. 1. Hospitalidade: direito e dever de todos. Petrópolis: Vozes, 2005.

, Virtudes para um outro mundo possível. v. 2. Convivência, Respeito e Tolerância. Petrópolis: Vozes, 2006.

, Virtudes para um outro mundo possível. v. 3. Comer e beber juntos e viver em paz. Petrópolis: Vozes, 2006. 
O que significa teologicamente Povo de Deus e Igreja Popular.

Concilium. Petrópolis. v.6, n.196, 1984

Igreja, carisma e poder, Petrópolis, Vozes, 1981.

Do lugar do pobre, ed. 4, Petrópolis, Vozes, 1997

E a Igreja se fez povo. Eclesiogênese: A Igreja que nasce da fé do povo. Petrópolis, Vozes, 1986

_

— A Ressurreição de Cristo - A nossa Ressurreição na morte, Petrópolis, Vozes, 1976.

Paixão de Cristo - Paixão do mundo, Petrópolis, Vozes, 2007.

, Saber cuidar: Ética do humano - compaixão pela terra, Petrópolis:

Vozes, 2017.

BOFF, LEONARDO, BOFF, CLODOVIS, Como fazer teologia da libertação, Petrópolis, Editora Vozes, 2007

BORBA, AMÂNDIA MARIA DE, Identidade em construção. São Paulo, EDUC: Univali, 2001

BRIONES, L."Para educar en la solidaridad. Líneas de acción", In: A.A.V.V., Sobriedade y solidaridad. Madrid, Editorial Popular, 1987

BULTMANN, Rudolf. Teologia do Novo Testamento. São Paulo: Teológica, 2004

CONGAR, Yves. A Igreja como Povo de Deus. Concilium. Petrópolis. n.1, v.1, 1965, p.14

Un pueblo messianico: la Iglesia, sacramento de la salvación .

Madrid: Cristiandad, 1976 
Eclesiologia. Desde San Agustín hasta nuestros dias. Madrid: BAC, 1976

CONGAR, YVES, Balizas de uma reflexão sobre o mistério dos pobres, in: GAUTHIER, PAUL, O Concílio e a Igreja dos pobres, Petrópolis, Vozes, 1967.

CONGREGACIÓN PARA LA DOCTRINA DE LA FE, Instrucción sobre libertad Cristiana y liberación ciudad del Vaticano 1986, in: VEKEMANS, Roger, CORDERO, Juan, Teologia de la Liberacion (Dossier alrededor de la Libertatis Conscientia), Caracas, Venezuela, 1988, p. 241 (CEDIAL: Centro de Estudios para el Desarrollo e Integración de América Latina).

CORDERO, Juan, Teologia de la Liberacion (Anásilis y Confrontación hasta Libertatis Nuntius), Caracas, Venezuela, 1986, p. 543 (CEDIAL: Centro de Estudios para el Desarrollo e Integración de América Latina).

DA COSTA, FERNANDO BRAGA, Moisés e Nilce: retratos biográficos de dois garis. Um estudo de psicologia social a partir da observação participante e entrevistas. Tese doutoral pela Universidade de São Paulo, Departamento de psicologia social e do trabalho, São Paulo, 2008

DELGADO, El amor preferencial por los pobres y marginados, in: Iglesia in América, Al encuentro de Jesucristo vivo, Ciudad del Vaticano, Libreria Editrice Vaticana, 2001, p. 277 (PONTIFICIA COMMISSIO PRO AMERICA LATINA).

DUPONT, J., A Igreja e a Pobreza, Petrópolis, Vozes, 1965.

DURAND, Xavier. Povo. In: LACOSTE, Jean-Yves. Dicionário Critico de Teologia, São Paulo, Loyola, 2004

DUSSEL, ENRIQUE, De Medellín a Puebla, São Paulo: Loyola, v. II: De Sucre à crise relativa do neofascismo - 1973-1977, São Paulo, Loyola, 1982 Historia de la Iglesia en America Latina, España: Mundo NegroEsquila Misional, 1992 
De Medellín a Sucre - 1968 - 1972, São Paulo: Edições Loyola, 1981

América Latina y conciencia Cristiana, Quito, Ecuador: IPLA: Departamento de Pastoral, 1970, v.8, p. 43-44, (Colección IPLA).

EDOM M. PABLO, El Evangelio de Pedro, Salamanca, Ediciones Sígueme, 2015 .

ESTRADA, J.A. Pueblo de Dios. In: ELLACURIA, I.. Mysterium Liberationis II. Conceptos fundamentales de la teologia de la liberación. Valladolid, 1990

FANIZZI, Nicolás Cotugno, La dignidad de la mujer y los desafios para la família Cristiana, in: Iglesia in América, Al encuentro de Jesucristo vivo, Ciudad del Vaticano, Libreria Editrice Vaticana, 2001, p. 253 (PONTIFICIA COMMISSIO PRO AMERICA LATINA).

FRANÇA MIRANDA, Mário de. Igreja e Sociedade. São Paulo: Paulinas, 2009

GONÇALVES, Paulo Sérgio Lopes, Liberationis Mysterium. O projeto sistemático da teologia da libertação. Um estudo teológico na perspectiva da regula fidei, Roma, Editrice Ponticia Università Gregoriana, 1997, p. 12, Tesi Gregoriana, Serie Teologia.

GUTIÉRREZ, GUSTAVO, Teologia de la liberación, Salamanca: Ediciones Sígueme, 1975 ¿Dónde dormirán los pobres? Lima, Peru, Instituto Bartolomé de las Casas/CEP, 2002 Uma teologia da libertação no contexto do terceiro milênio, in: $\mathrm{O}$ futuro da reflexão teológica na América Latina, São Paulo, Edições Loyola, 1998

HERR, Theodor, Teologia de la Liberacion y doctrina social de la Iglesia, in: VEKEMANS, Roger, CORDERO, Juan, Teologia de la Liberacion (Dossier alrededor de la Libertatis Conscientia), Caracas, Venezuela, 1988, p. 211 
(CEDIAL: Centro de Estudios para el Desarrollo e Integración de América Latina).

HÄRING, B. Vistas e perspectivas novas que a Const ituição abre para o futuro. In: BARAÚNA, G. A Igreja no mundo de hoje. Petrópolis: Vozes, 1967

IGLESIA CONDENA MISERIA Y OPRESIÓN, in: VEKEMANS, Roger, CORDERO, Juan, Teologia de la Liberacion (Dossier alrededor de la Libertatis Conscientia), Caracas, Venezuela, 1988, p. 285-286 (CEDIAL: Centro de Estudios para el Desarrollo e Integración de América Latina).

IGLESIAS, ENRIQUE, A América Latina diante do terceiro milênio: tendências e desafios, in: O futuro da reflexão teológica na América Latina, São Paulo, Edições Loyola, 1998

JIMENEZ, Roberto, TEOLOGIA DE LA LIBERACIÓN: PROYECTO HISTORICO Y TRES DE SUS CONCEPTOS CLAVES, in: JIMENEZ, Roberto, LEPELEY, Joaquin, VEKEMANS, Roger, CORDERO, Juan, Teologia de la Liberacion (Anásilis y Confrontación hasta Libertatis Nuntius), Caracas, Venezuela, 1986, p. 71 (CEDIAL: Centro de Estudios para el Desarrollo e Integración de América Latina).

J. L. IDÍGORAS, Vocabulário Teológico para a América Latina, São Paulo: Edições Paulinas, 1983

J. N. D. Kelly, Early Christian Creeds (Essex, England: Longman House, 1986)

JUNGES, JOSÉ ROQUE, Ecologia e Criação, São Paulo, Edições Loyola, 2001.

KÜNG, HANS. La estructura carismatica de la Iglesia. Concilium. Petrópolis. n.1, 1965

LACALLE, Fernando Sáenz, La defensa de la vida y los derechos humanos, in: Iglesia in América, Al encuentro de Jesucristo vivo, Ciudad del Vaticano, 
Libreria Editrice Vaticana, 2001, p. 235 (PONTIFICIA COMMISSIO PRO AMERICA LATINA).

LEPELEY, Joaquin, LA SANTA SEDE Y LA TEOLOGIA DE LA LIBERACIÓN, in: JIMENEZ, Roberto; LEPELEY, Joaquin; VEKEMANS, Roger, CORDERO, Juan, Teologia de la Liberacion (Anásilis y Confrontación hasta Libertatis Nuntius), Caracas, Venezuela, 1986, p. 220 (CEDIAL: Centro de Estudios para el Desarrollo e Integración de América Latina).

LIBÂNIO, J. B., Concílio Vaticano II. Em busca de uma primeira compreensão, São Paulo, Edições Loyola, 2005.

LIBÂNIO, JOÃO B., BINGEMER, MARIA CLARA, Escatologia cristãa, Petrópolis, Vozes, 1985, Série III - A libertação na História, Tomo X, Coleção Teologia e Libertação

LIBERDAD Y LIBERACION, Instrucción sobre libertad Cristiana y liberación ciudad del Vaticano 1986, in: VEKEMANS, Roger, CORDERO, Juan, Teologia de la Liberacion (Dossier alrededor de la Libertatis Conscientia), Caracas, Venezuela, 1988, p. 276 (CEDIAL: Centro de Estudios para el Desarrollo e Integración de América Latina).

MOLTMANN, JÜRGEN, O caminho de Jesus, Petrópolis, Vozes, 1994 MONLOUBOU, Louis. Igreja. In: MONLOUBOU,L; DU BUIT, F. M. Dicionário Bíblico Universal, São Paulo: Vozes, 2003.

MORENO REJÓN, FRANCISCO, La instrucción sobre libertad Cristiana y liberación, in: VEKEMANS, Roger, CORDERO, Juan, Teologia de la Liberacion (Dossier alrededor de la Libertatis Conscientia), Caracas, Venezuela, 1988, p. 565-566 (CEDIAL: Centro de Estudios para el Desarrollo e Integración de América Latina).

MÜLLER, GERHARD LUDWIG, Pobre para os pobres, São Paulo, Paulinas, 2014. 
card., Povera per i poveri, Città del Vaticano, Libreria Editrice Vaticana, 2014.

MÜLLER, GERHARD LUDWIG, GUTIÉRREZ, GUSTAVO, Ao lado dos pobres, São Paulo, Paulinas, 2014.

MUÑOZ, RONALDO, Nueva conciencia de la Iglesia en América Latina, Salamanca: Ediciones Sígueme, 1974

OVÍDIO, As Metamorfoses. Rio de Janeiro: Editora Tecnoprint, 1983

PITTAU, Giuseppe, La Iglesia en el campo de la educación Evangelizar los centros educativos, in: Iglesia in América, Al encuentro de Jesucristo vivo, Ciudad del Vaticano, Libreria Editrice Vaticana, 2001, p. 209 (PONTIFICIA COMMISSIO PRO AMERICA LATINA).

PAULO VI. Encíclica Ecclesiam Suam. Promulgada em 06 de agosto de 1964. In: DOCUMENTOS DE PAULO VI. São Paulo: Paulus, 1997. Série Documentos da Igreja 3. Cfr. pp. 43-67 capítulo sobre "O diálogo". ES n. 46, p. 51

PLATAO, Fedon, (Comentário Coleção os Pensadores - Fedon XIX)

PREDEBON, ARISTÓTELES ANGHEBEN, Edição do manuscrito $e$ estudo das metamorfoses de Ovídio traduzidas por Francisco José Freire, Tese apresentada ao programa de graduação em Letras Clássicas, do Departamento de Letras Clássicas e Vernáculas da Faculdade de Filosofia, Letras e Ciências Humanas da Universidade de São Paulo. São Paulo, 2006.

PUBLIO OVIDIO NASÓN, Metamorfosis, Barcelona, Editorial Bruguera, 1983, Edición Bilingue, Traducíon: Antonio Ruiz de Elvira.

RATZINGER, CARDENAL JOSEPH, Jesucristo Evangelizador, in: Iglesia in América, Al encuentro de Jesucristo vivo, Ciudad del Vaticano, Libreria Editrice Vaticana, 2001, p. 57-58 (PONTIFICIA COMMISSIO PRO AMERICA LATINA).

RATZINGER, JOSEPH, O novo Povo de Deus, São Paulo, Paulinas, 1969. 
RUANO, EDGAR MOROS, La filosofia de la liberación, Mérida, Venezuela: Universidad de los Andes Consejo de Publicaciones, 1995

RUBIO, ALFONSO GARCIA Unidade na pluralidade: $O$ ser humano à luz da fé e da reflexão cristãs, ed. 2, São Paulo, Paulinas, 1989

SANDRI, Leonardo, La identidad Cristiana de América, in: Iglesia in América, Al encuentro de Jesucristo vivo, Ciudad del Vaticano, Libreria Editrice Vaticana, 2001, p. 183 (PONTIFICIA COMMISSIO PRO AMERICA LATINA).

SCANNONE, JUAN CARLOS, O comunitarismo como alternativa viável, in: O futuro da reflexão teológica na América Latina, São Paulo, Edições Loyola, 1998

SOBRINO, JON, Resurrección de la verdadera Iglesia. Los pobres, lugar teológico de la eclesiología, Santander, Sal Terrae, 1981

O seguimento de Jesus como discernimento cristão, In: Concilium, Petrópolis, Vozes, 139 (1978/9)

A fé em Jesus Cristo, Ensaio a partir das vítimas. Petrópolis: Editora Vozes, 2000, p. 63, Série II, O Deus que liberta seu povo (Coleção Teologia e Libertação).

Jesus, o Libertador, I A história de Jesus de Nazare, Petrópolis: Editora Vozes, 1996, p. 30, Série II, O Deus que liberta seu povo (Coleção Teologia e Libertação)

_ Cristologia a partir da América Latina, Petrópolis, Vozes, 1983.

—_ Fora dos pobres não há salvação, São Paulo: Paulinas, 2008.

SOUZA, JESSÉ, A invisibilidade da raça e a invisibilidade da classe, in: A invisibilidade da desigualdade brasileira, Editora UFMG, Belo Horizonte, 2006

TESCAROLI, Cirilo, P., Iglesia deve promover autentica liberación, in: VEKEMANS, Roger, CORDERO, Juan, Teologia de la Liberacion (Dossier alrededor de la Libertatis Conscientia), Caracas, Venezuela, 1988, p. 284 
(CEDIAL: Centro de Estudios para el Desarrollo e Integración de América Latina).

TEPE, VALFREDO, Estamos Salvos, São Paulo, Edição Paulinas, 1982.

TILLARD, J.M.R. A teologia subjacente à Constituição: a Igreja e os valores terrestres. In: BARAÚNA, A Igreja no mundo de hoje, p. 230

TRUJILlO, Alfonso López, Teología de la Liberación. Situación en América Latina, perspectivas, in: Iglesia in América, Al encuentro de Jesucristo vivo, Ciudad del Vaticano, Libreria Editrice Vaticana, 2001, p. 68 (PONTIFICIA COMMISSIO PRO AMERICA LATINA).

VEKEMANS, Roger, CORDERO, Juan,TEOLOGIA DE LA LIBERACIÓN (DOSSIER), in: JIMENEZ, Roberto; LEPELEY, Joaquin; VEKEMANS, Roger,

VELASCO, R. A., A Igreja de Jesus. Processo histórico de consciência social, Petrópolis, Vozes, 1996. 


\section{Documentos Magisteriais}

JOÃO PAULO II, “Homilia Sto. Domingo", Acta Apostolicae Sedis, LXXI, p. $154(25 / 09 / 1979)$.

JOÃO PAULO II, Exortação Apostólica Ecclesia in America, n. 29.

CELAM. Documentos do CELAM: Conclusões das Conferências do Rio de Janeiro, Medellín, Puebla e Santo Domingo. São Paulo: Paulus, 2004.

CELAM. Documento de Aparecida. São Paulo: Loyola, 2007.

CNBB, Doc. 11. Diretório para missas com grupos populares. São Paulo:

Paulinas (Coleção azul), 1977.

_. Doc. 15. Diretrizes gerais da ação pastoral da Igreja no Brasil 1979 -

1982. São Paulo: Paulinas (Coleção azul), 1979.

CNBB. Doc 17. Igreja e problemas da terra. São Paulo: Paulinas (Coleção azul), 1980.

Doc. 22. Reflexão cristã sobre a conjuntura política. São Paulo:

Paulinas(Coleção azul), 1981.

Doc. 23. Solo urbano e ação pastoral. São Paulo: Paulinas (Coleção

azul), 1982.

. Doc. 25. Comunidades eclesiais de base na igreja do Brasil. São

Paulo:

Paulinas (Coleção azul), 1982. 
. Doc. 28. Diretrizes gerais da ação pastoral da Igreja no Brasil $1983-$

1986. São Paulo: Paulinas (Coleção azul), 1983.

. Doc. 38. Diretrizes gerais da ação pastoral da Igreja no Brasil 1987-

1990. São Paulo: Paulinas (Coleção azul), 1987.

. Doc. 40. Igreja: comunhão e missão. São Paulo: Paulinas (Coleção azul),

1988.

. Doc. 42. Exigências éticas da ordem democrática. São Paulo: Paulinas

(Coleção azul), 1989. . Doc. 45. Diretrizes gerais da ação pastoral da Igreja no Brasil $1991-$

1994. São Paulo: Paulinas (Coleção azul), 1991.

. Doc. 47. Educação Igreja e sociedade. São Paulo: Paulinas (Coleção

azul), 1992.

. Doc. 48. Das diretrizes a Santo Domingo. São Paulo: Paulinas (Coleção

azul), 1992.

. Doc. 50. Ética: pessoa e sociedade. São Paulo: Paulinas (Coleção azul),

1993. 
. Doc. 54. Diretrizes gerais da ação evangelizadora da Igreja no Brasil

1995-1998. São Paulo: Paulinas (Coleção azul), 1995.

Doc.56. Rumo ao novo milênio. São Paulo: Paulinas (Coleção azul),

1996.

Doc. 58. Pronunciamentos da CNBB - 1992-1996. São Paulo:

Paulinas

(Coleção azul), 1997.

_. Doc.61. Diretrizes gerais da ação evangelizadora da Igreja no Brasil-

1999-2002. São Paulo: Paulinas (Coleção azul), 1999.

Doc.69. Exigências evangélicas e éticas de superação da miséria e da

fome. São Paulo: Paulinas (Coleção azul), 2002.

CONCÍLIO VATICANO II. Apostolicam Actuositatem. Decreto do Concílio

Vaticano II sobre o apostolado dos leigos. São Paulo: Paulinas, 1976.

Christus Dominus. Decreto do Concílio Vaticano II, Sobre o Múnus

Pastoral dos Bispos na Igreja. São Paulo: Paulinas, 1990.

Dignitatis Humanae. Declaração do Concílio Vaticano II sobre a

liberdade religiosa. Petrópolis: Vozes, 1966.

. Gaudium et Spes. Constiuição pastoral do Concílio Vaticano II sobre

a

Igreja no mundo de hoje. São Paulo: Paulinas, 1966 
RERUM NOVARUM, in: Once grandes mensajes, Madrid: Biblioteca de Autores Cristianos, 1993.

CENTESIMUS ANNUS, in: Once grandes mensajes, Madrid: Biblioteca de Autores Cristianos, 1993.

QUADRAGESIMO ANNO, in: Once grandes mensajes, Madrid: Biblioteca de Autores Cristianos, 1993.

MATER ET MAGISTRA, in: Once grandes mensajes, Madrid: Biblioteca de Autores Cristianos, 1993.

PACEM IN TERRIS, in: Once grandes mensajes, Madrid: Biblioteca de Autores Cristianos, 1993.

ECCLESIAM SUAM, in: Once grandes mensajes, Madrid: Biblioteca de Autores Cristianos, 1993.

POPULORUM PROGRESSIO, in: Once grandes mensajes, Madrid: Biblioteca de Autores Cristianos, 1993.

LABOREM EXERCENS, in: Once grandes mensajes, Madrid: Biblioteca de Autores Cristianos, 1993.

SOLLICITUDO REI SOCIALIS, in: Once grandes mensajes, Madrid: Biblioteca de Autores Cristianos, 1993.

OCTOGESIMA ADVENIENS, in: Once grandes mensajes, Madrid: Biblioteca de Autores Cristianos, 1993. 